\author{
UNIVERSIDADE DE SÃO PAULO \\ MUSEU DE ARQUEOLOGIA E ETNOLOGIA \\ PROGRAMA DE PÓS-GRADUAÇÃO EM ARQUEOLOGIA
}

\title{
Estudo da cultura material lítica e cerâmica dos sítios Silva Serrote e Menezes : análise das cadeias operatórias dos vestígios de culturas pré-coloniais do alto Paranaíba, Minas Gerais.
}

\author{
Marina Teixeira Figueiredo \\ Dissertação apresentada ao programa de pós-graduação \\ em Arqueologia, do Museu de Arqueologia e Etnologia da \\ Universidade de São Paulo, como exigência para a \\ obtenção do título de Mestre em Arqueologia.
}

Orientadora: Profa Dra Márcia Angelina Alves

Linha de Pesquisa:- Artefatos e cultura material: significados e potencialidades

São Paulo

2008 
Estudo da cultura material lítica e cerâmica dos sítios Silva Serrote e Menezes: análise das cadeias operatórias dos vestígios de culturas pré-coloniais do Alto Paranaíba, Minas Gerais

Banca examinadora

Presidente da Banca:

Membros

São Paulo, dezembro de 2008 
Aos meus pais, Elisabete Baptista Teixeira e Sérgio Feijó Figueiredo, pelo apoio incondicional.

Tudo o que eu pensei saber ainda é mistério qual é a relação de Crato lá com New Orleans? a chave do amor é uma risada ou é um jeito sério?

é singular o fecho todo ou já são vários fins? é sempre o mesmo Deus ou troca como um Ministério? é sempre a mesma afirmação ou já são vários sins? é cheia a taça da paixão ou é um rio estéril? são sete demos musicais ou doze querubins? se a vida continua ou não ainda é mistério o ciclo começa por onde: noite ou manhã? o barco do destino é uma prisão ou é um grande império? quem é que descerá dos céus nos braços de Tupã? depois que a gente já mentiu a coisa ainda é sã? a sorte é uma abstração, o azar é um mistério e Deus freqüenta a arquibancada do Maracanã. (Mistérios, Oswaldo Montenegro) 


\section{Agradecimentos}

Agradeço minha orientadora, Profa ${ }^{\mathrm{D}}{ }^{\mathrm{a}}$ Márcia Angelina Alves, pela confiança depositada no meu trabalho e pela oportunidade oferecida. Muito obrigada pela compreensão e apoio durante épocas difíceis, por me mostrar o caminho e dispor de seu tempo e dedicação, pela orientação séria e comprometida. Meus sinceros agradecimentos.

Agradeço ao Prefeito municipal de Perdizes-MG, Sr. Edno José de Oliveira e a secretária municipal de Cultura Sra. Profa. Lindamar de Lourdes Alvarenga Magalhães pelo apoio incondicional a pesquisa laboratorial e aos funcionários do Museu de Arqueologia de Perdizes e demais servidores.

Agradeço ao ex-prefeito de Perdizes, Sr. Alcides Flausino Dias(1989 a 1992 e 2001 a 2004) pelo custeio das escavações e prospecções desenvolvidas no sítio Menezes no anos de 1990 e1991, pela assinatura do convênio entre a Prefeitura Municipal de Perdizes e a Universidade de São Paulo, intermediada pelo Museu de Arqueologia e Etnologia da USP , em 1991.

Agradeço ao ex-prefeito de Guimarânia -MG, Senhor Osmario Gonçalves dos Reis, pelo custeio da pesquisa de campo no sítio Silva Serrote efetuada no ano de 1985.

Ao Ilustríssimo Senhor Delvo Silva, proprietário da Fazenda Serrote e família pelo apoio às pesquisas no sítio Silva Serrote.

Agradeço à viúva do Senhor. Adão Dias de Menezes, proprietário da fazenda São Francisco do Borja, Sra. Maria Eurípedes Dias de Menezes, a sua filha Profa. Marilene Dias de Menezes Campos, e ao esposo administrador de empresas, Sr. João Geraldo Campos, aos demais familiares pelo apoio às pesquisas de campo- prospecção durante o ano de 1990 e escavação em 1991 e

pelo suporte dados aos arqueólogos; graças à família, foi possível decifrar o "escorredor de macarrão dos índios, ou seja, o cuzcuzeiro, vetor social de consumo do milho, encontrado casualmente em um eixo de vertente próximo à casa sede da fazenda.

Nossos sinceros agradecimentos pela atenção com a equipe, recebida durante um mês com guloseimas diárias (pão-de-queijo, broa, café, chá e leite 
produzidos na fazenda) e sem mencionar os inúmeros almoços oferecidos aos arqueólogos.

À Secretaria acadêmica do MAE-USP, a Regina Silva, a Vanuza Gregório e Geraldo Miranda pelo cuidado, eficiência e carinho. À Conceição Borges e Eleuza Gouveia pela atenção e receptividade de sempre.

Ao fotógrafo Prof. Ms. Wagner Souza e Silva (MAE-USP) pelas e fotografias dos conjuntos líticos e cerâmicos registrados

À Profa Dra. Sandra Lacerda Campos e Evaristo Pereira Goulart, membros da banca examinadora de qualificação deste trabalho, agradeço às sugestões e críticas que direcionaram esta dissertação.

Ao Prof. Dr Gergely Szabó pela leitura das lâminas petrográficas, pela prestatividade, profissionalismo e solidariedade com meu trabalho. Meus sinceros agradecimentos.

Agradeço minha orientadora de monografia de bacharelado, $\operatorname{Prof}^{\mathrm{a}} \operatorname{Dr}^{\mathrm{a}}$ Ana Keila Pinezi (UFABC- Universidade Federal do $A B C$ ) pelo incentivo à vida acadêmica e amizade.

Aos meus amigos e companheiros de mestrado: Ms. Maria Bernadete Póvoa, Ms.Tais Pagoto Bélo, Ms. Arkley Marques Bandeira, Ms.João Cabral de Medeiros, e aos mestrandos Mirian Liza Forancelli e Elbio e Dr. Marcelo Fagundes pelo carinho, paciência e ajuda.

Agradeço aos amigos, Patrícia Pacini, Caroline Borges, Patrícia Manfredi, Danilo More e Dabel Moré, Juliano Alves e Griselda Vargas, Mariana Fuzissaki e Flávia Vidal e a todos do grupo Caminho do Louco, pelo apoio emocional e incentivo.

Agradeço especialmente à minha família, Elisabete Baptista Teixeira e Sérgio Feijó Figueiredo pelo amor, paciência e confiança e a meu irmão Rafael Figueiredo e à minha madrasta Nádia Figueiredo. Amo vocês. 


\section{RESUMO}

A presente dissertação apresenta o estudo realizado sobre as cadeias operatórias da cultura material lítica coletada nos sítios Silva Serrote (Guimarânia) e Menezes (Perdizes), e a cerâmica coletada no segundo sítio. O objetivo é caracterizar aspectos culturais de populações pré-coloniais do vale do ParanaíbaMG, por meio da análise tecnológica dos vestígios materiais deixados no registro arqueológico, com o processamento de datações absolutas por Carbono $14 \mathrm{e}$

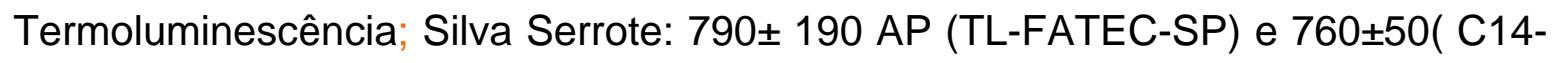
Gif-sur-Yvette) e Menezes 572 \pm 80 AP(TL-FATEC-SP).

A análise tecnológica do material lítico do Silva Serrote (campanha 1985) versou sobre o estudo de 703 peças e 28 do Menezes (campanha 1991) e foram analisados 1939 elementos cerâmicos do sítio Menezes, coletados no âmbito do projeto arqueológico regional Quebra-Anzol. Por meio desta análise, foi possível a caracterização de alguns aspectos sócio-culturais sobre o modo de vida, assim como sobre o proceder e a escolha tecnológica destas populações.

Palavras-chave: cadeia operatória, tecnologia lítica, tecnologia cerâmica, escolhas culturais, turismo. 


\begin{abstract}
This research presents a study about operational chains of lithic culture collected in the sites Silva Serrote and Menezes, and the pottery collected in the Menezes site. The goal is to establish some cultural aspects of the pre-colonial population that lived in the Paranaíba Valley (Minas Gerais State) using lithic and pottery technological analysis of this material, abandoned in the archaeological record. The material was dated by termoluminescence and Carbon 14.

The lithic analysis of the Silva Serrote site was composed by 703 (collected in 1985) pieces and Menezes' 28 pieces(collected in 1991).

The pottery analysis of the Menezes site embraced altogether 1939 pieces. This master thesis is related to a major sectional archaeological project named Quebra-Anzol. Through this work, it was possible to characterize some social and cultural aspects about the way of life, operational sequences and technological choices made by these groups.
\end{abstract}

Key words: operational chains, lithic technology, pottery technology,cultural choices, tourism. 


\section{SUMÁRIO}

Página

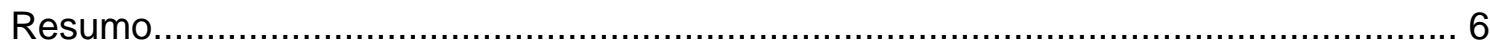

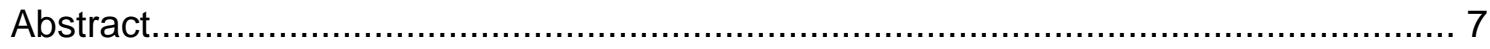

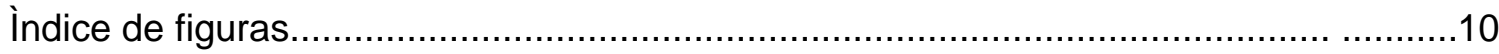

Índice de mapas e pranchas............................................................................... 11

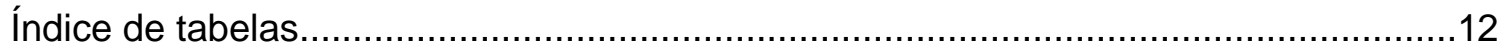

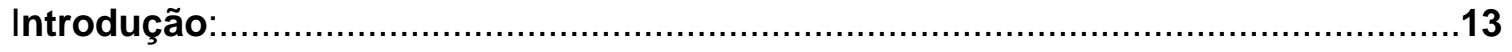

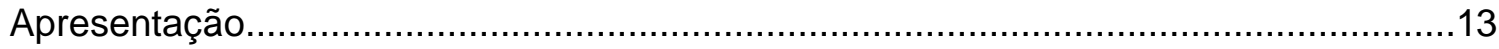

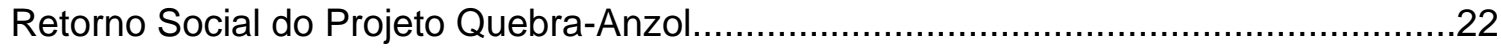

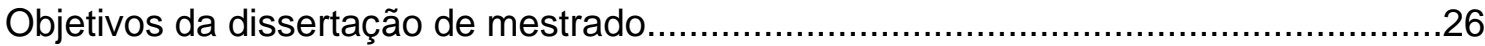

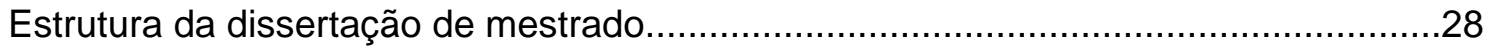

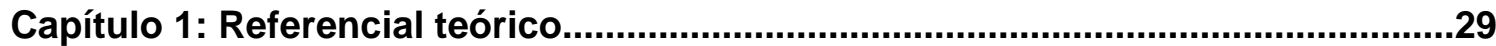

1.1 .1A antropologia das técnicas e o conceito de cadeias operatórias......................29

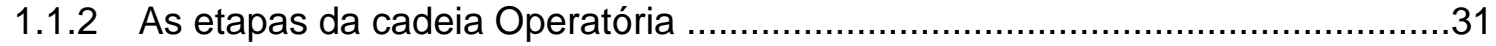

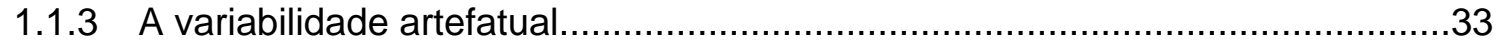

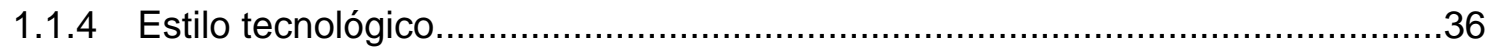

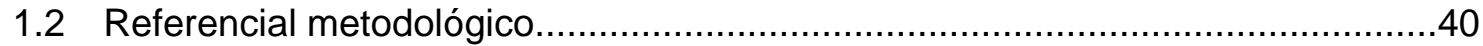

1.3 Metodologia das pesquisas de campo.....................................................49

Capítulo 2: A Ambientação e escavação do sítio Silva Serrote e Menezes...........50

2.1 Ambientação do sítio Silva Serrote.......................................................... 50

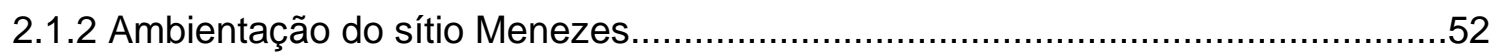

2.2.1 Pesquisa de campo no sítio Silva Serrote.................................................. 57

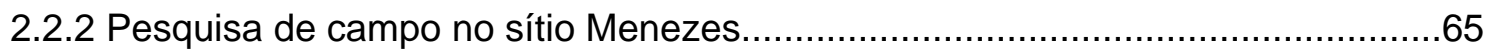

Capítulo 3 - Cadeia operatória e análise da indústria lítica do sítio Silva Serrote e Menezes

3.1 Análise da indústria lítica do sítio Silva Serrote e cadeia operatória.....................72

3.2 Análise da indústria lítica do sítio Menezes e cadeia operatória..........................82

Capítulo 4: Cadeia operatória e análise tecnológica da indústria cerâmica.91

4.1 Análise tecnotipológica da produção cerâmica.............................................91

4.2 A cadeia operatória da cerâmica do sítio Menezes..............................................96

Capítulo 5- Reconstituição dos vasilhames do sítio Menezes e a análise da lâminas pela técnica da microscopia petrográfica.......................................................109

5.1- Breve análise da reconstituição dos vasilhames.......................................109 
5.2 As lâminas petrográficas........................................................ 118

6.Análise inter sítios e considerações finais...........................................133

7. Referencias Bibliográficas..................................................................138

7.1 Bibliografia consultada....................................................................144 
Foto 1: Exposição do Museu de Arqueologia de Perdizes............................................25

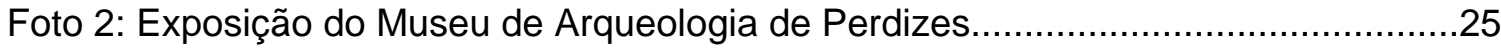

Foto 3: Perfil estratigráfico -mancha 1/Trincheiras/Decapagem -Silva Serrote............63

Foto 4: Vista Geral do sítio - início de execução das trincheiras..................................64

Foto 5: Decapagem mancha 1; conclusão perfil e decapagem...................................64

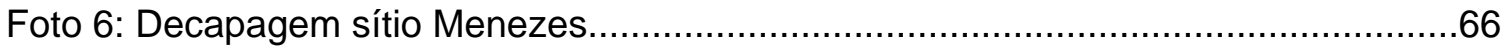

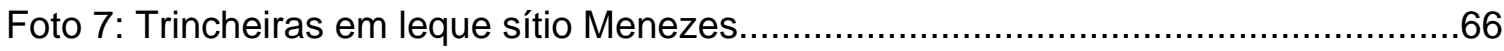

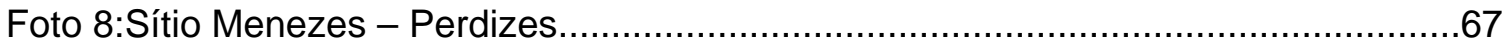

Foto 9:Decapagem da mancha 3 - sítio Menezes ..............................................68

Foto 10: Sítio Menezes:execução do perfil e evidenciação.........................................68

Foto 11: Sítio Menezes:perfil/ remontagem vestígios.............................................69

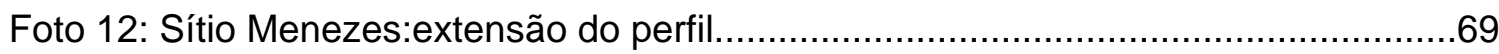

Foto 13: Sítio Menezes - medidas do perfil...................................................... 70

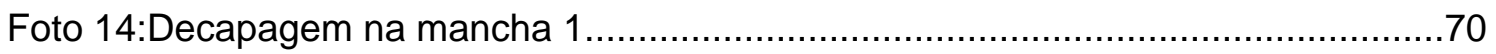

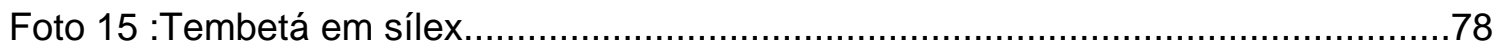

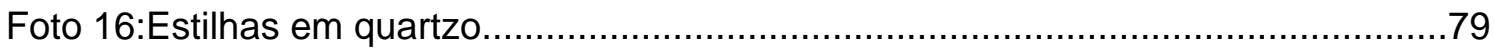

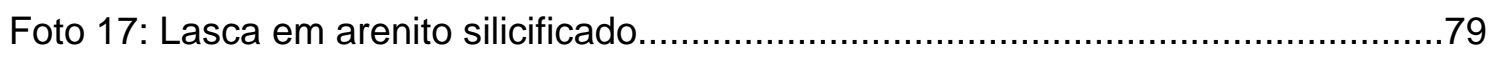

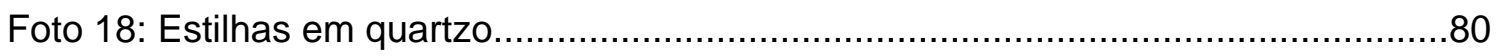

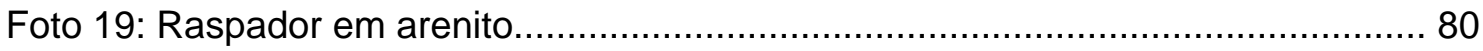

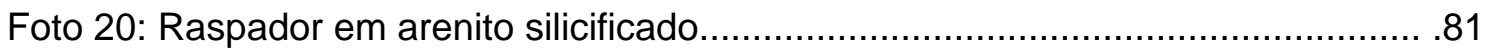

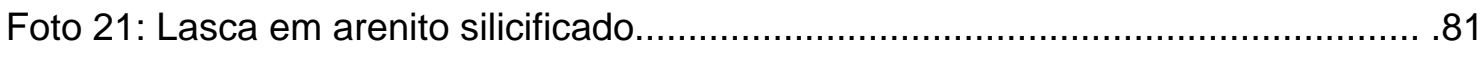

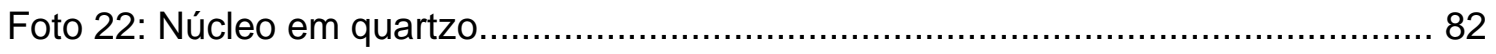

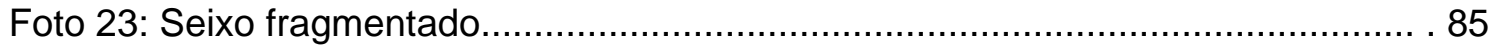

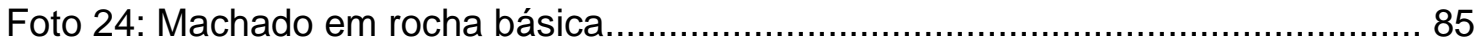

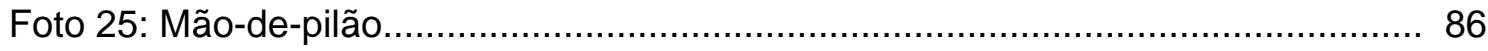

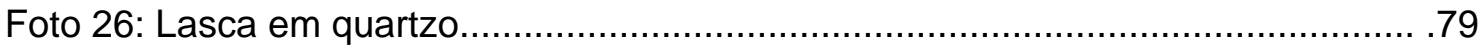

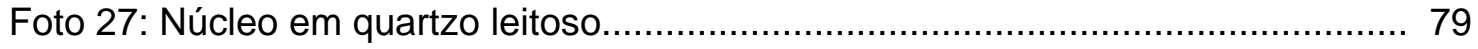

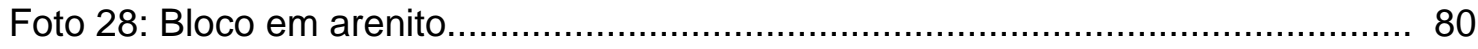

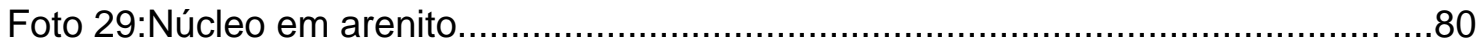

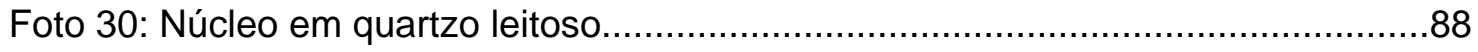

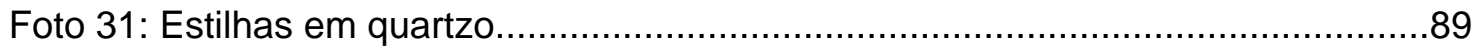

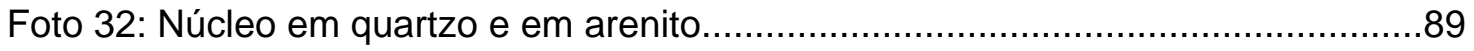

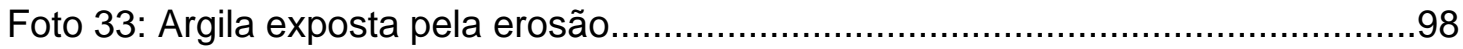




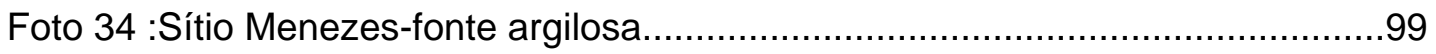

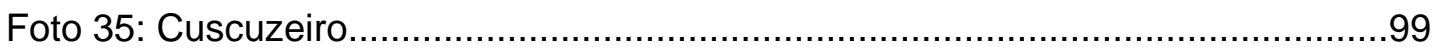

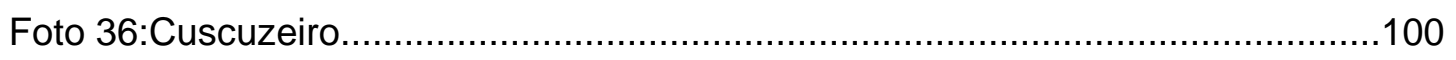

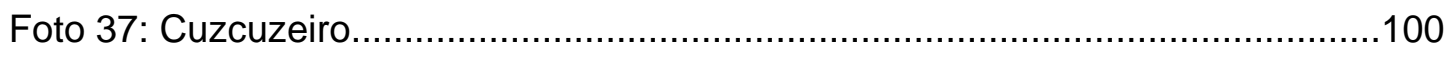

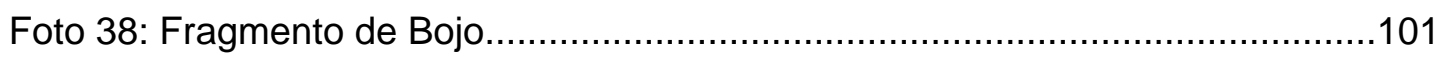

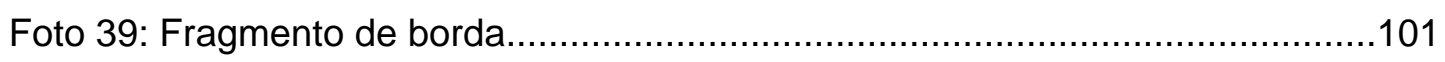

Foto 40: Fragmento de bojo.............................................................

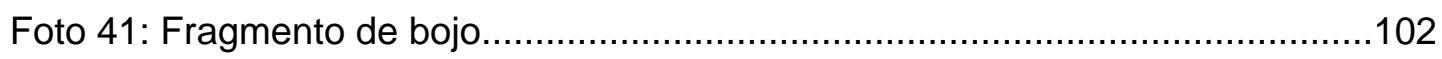

Foto 42: Fragmento de borda............................................................... 103

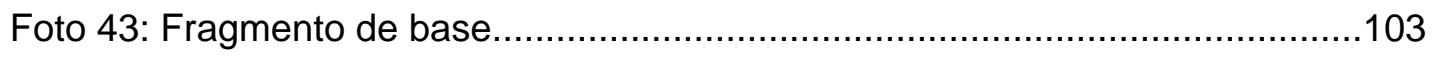

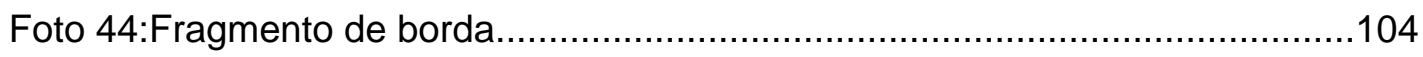

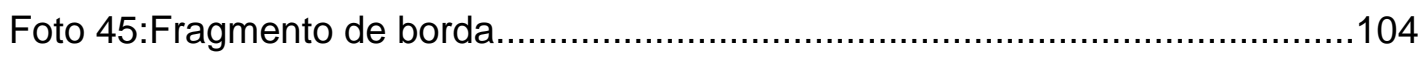

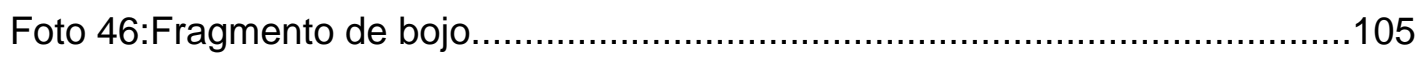

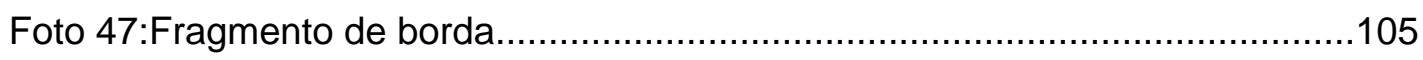

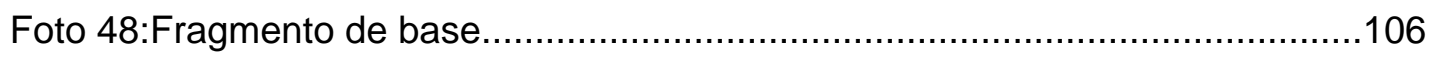

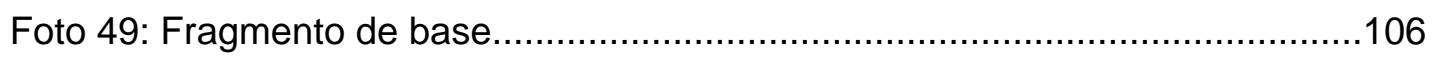

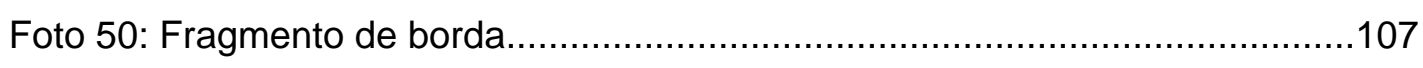

Foto 51: Fusos de cerâmica do Projeto Quebra-Anzol......................................107

Foto 52: Fuso de cerâmica do Sítio Menezes............................................... 108

Foto 53: Urna exposta no Museu de Arqueologia de Perdizes...........................118

Foto 54:Urna exposta no Museu de Arqueologia de Perdizes............................118

ÍNDICE DE MAPAS E PRANCHAS

PÁGINA

Mapa 1: Mapa dos sítios do Projeto Quebra Anzol..........................................18

Mapa 2: Localização da cidade de Guimarânia................................................51

Mapa 3:Localização da cidade de Perdizes.................................................53

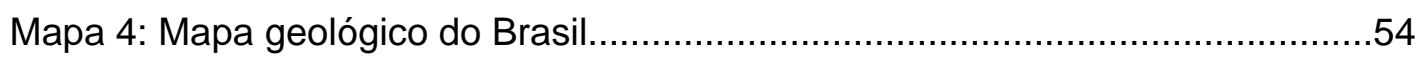

Mapa 5: Vegetação:Estado de Minas Gerais...............................................55

Mapa 6: Hidrografia:Estado de Minas Gerais...............................................56

Mapa 7: Sítio Silva Serrote-Guimarânia-MG- Situação geral do sítio....................59

Mapa 8: Panorama das escavações no sítio Silva Serrote.................................60

Mapa 9: Croqui do sítio Silva Serrote......................................................61

Mapa 10: Croqui Decapagem 3- Mancha 1/sítio Silva Serrote............................... 62

Mapa 11: Panorama das escavações no sítio Menezes....................................71

Prancha 1: Reconstituição de forma de vasilhame cerâmico do sítio Menezes...110

Prancha 2: Reconstituição de forma de vasilhame cerâmico do sítio Menezes...111

Prancha 3: Reconstituição de forma de vasilhame cerâmico do sítio Menezes...112 
Prancha 4: Reconstituição de forma de vasilhame cerâmico do sítio Menezes..............113

Prancha 5: Reconstituição de forma de vasilhame cerâmico do sítio Menezes..............114

Prancha 6: Reconstituição de forma de vasilhame cerâmico do sítio Menezes..............115

Prancha 7: Reconstituição de forma de vasilhame cerâmico do sítio Menezes..............116

Prancha 8: Reconstituição de forma de vasilhame cerâmico do sítio Menezes..............117

ÍNDICE DE TABELAS, FICHAS E FOTOMICROGRAFIAS PÁGINA

Ficha 1: Ficha de análise da indústria lítica.......................................................... 73

Ficha 2: Ficha de análise da indústria cerâmica........................................................

Tabela 1: Peças líticas analisadas Silva Serrote-Quantidade X distribuição espacial.......73

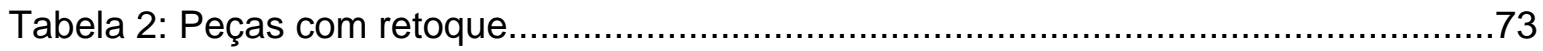

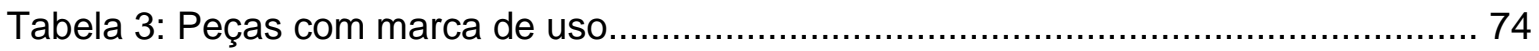

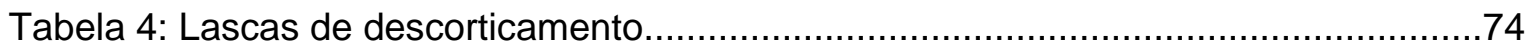

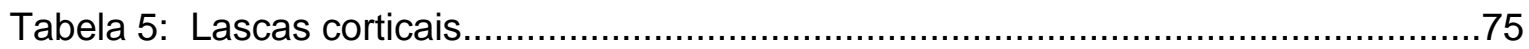

Tabela 6: O uso social dos artefatos do sítio Silva Serrote.........................................78

Tabela 7: Peças líticas analisadas Menezes-Quantidade X distribuição espacial............83

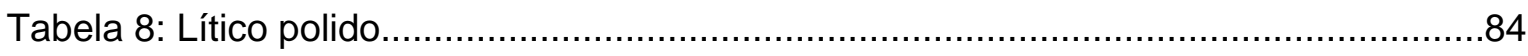

Tabela 9: O uso social social dos artefatos do sítio Menezes.......................................90

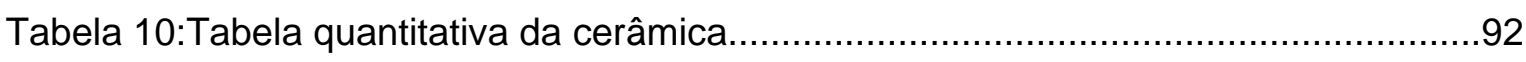

Tabela 11: Tabela de elementos morfológicos $X$ localização........................................93

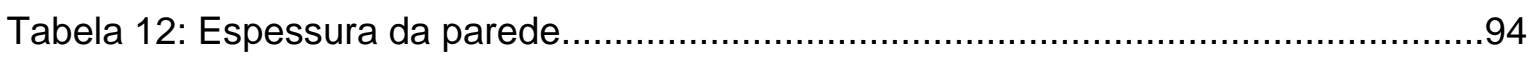

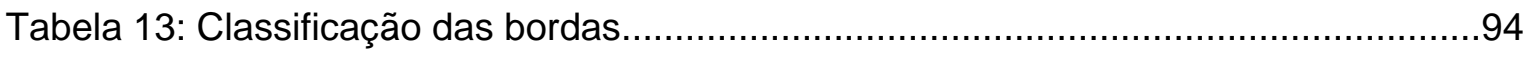

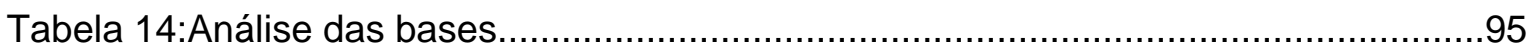

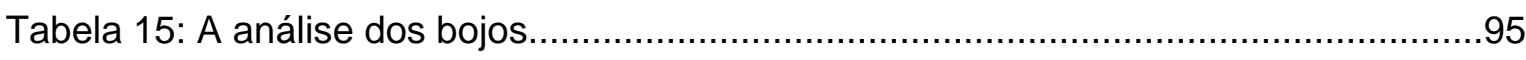

Tabela 16.: O uso social da Cerâmica do sítio Menezes.............................................97

Fotomocrografia 1- Mancha 1-filtros polarizadores cruzados.....................................121

Fotomocrografia 2 - Mancha 1- filtros polarizadores paralelos.................................122

Fotomocrografia 3- Mancha 2 -filtros polarizadores paralelos..................................123

Fotomocrografia 4- Mancha 2- filtros polarizadores cruzados.....................................124

Fotomocrografia 5-Mancha 3- filtros polarizadores cruzados....................................125

Fotomocrografia 6 - Mancha 3- filtros polarizadores paralelos.................................126

Fotomocrografia 7 - Mancha 4 - filtros polarizadores paralelos.................................127

Fotomocrografia 8 - Mancha 4 - filtros polarizadores cruzados..................................128

Fotomocrografia 9 -Perfil 1 - filtros polarizadores cruzados......................................129

Fotomocrografia 10- Perfil 1- filtros polarizadores paralelos....................................130

Fotomocrografia 11- Perfil 1- filtros polarizadores paralelos.....................................131

Fotomocrografia 12- Perfil 1- filtros polarizadores cruzados.....................................132 


\section{Estudo da cultura material lítica e cerâmica dos sítios Silva Serrote e Menezes: análise das cadeias operatórias dos vestígios de culturas pré-coloniais do Alto Paranaíba, Minas Gerais.}

\section{Apresentação}

O cerne da presente dissertação de Mestrado centra-se no estudo das cadeias operatórias da cultura material lítica coletada nos sítios Silva Serrote (Guimarânia) e Menezes (Perdizes), e a cerâmica coletada no segundo sítio, com o objetivo de caracterizar aspectos culturais de populações pré-coloniais do vale do Paranaíba-MG, por meio da análise tecnológica dos vestígios materiais deixados no registro arqueológico, com 0 processamento de datações absolutas por Carbono 14 e Termoluminescência; Silva Serrote: 760 \pm 50 ( C14-Gif-sur-Yvette e 790 190 AP((TL-FATEC-SP) e Menezes 572 \pm 80 AP(TLFATEC-SP).

A análise tecnológica do material lítico do Silva Serrote (campanha 1985) abrangeu o estudo de 703 peças e 28 do Menezes (campanha 1991); da mesma forma, foram analisados 1939 elementos cerâmicos, coletados no âmbito do projeto regional QuebraAnzol.

A escavação foi realizada em 1985 no sítio Silva Serrote, localizado na fazenda Serrote, município de Guimarânia-MG, localizado a 9 km da sede municipal. Em 1991, foi desenvolvida a escavação no sítio Menezes, situado na fazenda São Francisco de Borja, distante $9 \mathrm{~km}$ da sede municipal de Perdizes-MG;o método empregado nas pesquisas de campo foi o etnográfico de "superfícies amplas" de Leroi-Gourhan (1972), adaptado ao solo tropical do Brasil por Pallestrini(1975).

Este estudo vincula-se ao projeto arqueológico Quebra Anzol, desenvolvido na região do Triângulo mineiro, vale do Paranaíba, a partir de 1980, pela Profa ${ }^{\mathrm{a}} \mathrm{Dr}^{\mathrm{a}}$ Márcia Angelina Alves, docente do Museu de Arqueologia e Etnologia da Universidade de São Paulo, o qual desenvolve um programa de prospecções e escavações sistemáticas no vale do ParanaíbaMG, visando identificar e compreender os padrões de assentamento, a estratigrafia, as estruturas e os contextos espaciais por meio da coleta e da análise da cultura material evidenciada nas escavações e o reconhecimento de permanências e de mudanças culturais ocorridas nesta região no período pré-histórico e pré-colonial. (Alves, 1991). 
Em 2004, em decorrência do aumento da produção científica, Alves reformulou os objetivos do Projeto Quebra-Anzol de forma a adaptá-los às novas questões e tendências do projeto (Alves, 2004)

- Detectar, registrar junto ao IPHAN, mapear e pesquisar sítios arqueológicos situados na região do triângulo mineiro para elaborar a história indígena da região do Vale do Paranaíba (pré-colonial, de contato, etc);

- Detectar a antiguidade da ocupação humana no Vale do Paranaíba;

- Estabelecer por meio das escavações intensivas, em sítios os padrões de assentamentos (temporais e semipermanentes) em assentamentos localizados em relevos de vertente e chapadões.

- Selecionar os sítios para serem escavados em uma perspectiva intensiva no âmbito sítios-escola, para a realização de estágios (em pesquisas de campo), para estagiários em arqueologia, sob a orientação de docentes pesquisadores;

- Revelar o empírico em uma dimensão espacial/ temporal com a evidenciação de estruturas (contextos) arqueológicos associadas à elaboração de plantas complexas, de sítios pré-históricos e pré-coloniais, acompanhados de registros gráficos, fotográficos etc; e do clássico diário de campo.

- Delinear, a partir da pesquisa empírica de campo o processo de desenvolvimento cultural do povoamento pré-colonial e de contato centrado na continuidade e mudança cultural (diversidade crono-cultural);

- Estabelecer o modo de vida de populações pré-coloniais associado ao modo de produção, via evidenciação da totalidade social do assentamento para reconstruir a organização espacial, a especialização do trabalho, o processo de produção da indústria lítica, da cerâmica, o emprego social dos artefatos - em pedra, cerâmica, osso, concha etc;

- Reconstituir o cotidiano de grupos pré-coloniais na dinâmica de sua vida social;

- Desenvolver estudos tecnotipológicos, associados à estratigrafia e estruturas;

- Reconstituir o processo produtivo da cerâmica e do lítico, e dos artefatos em ossos, das fontes de matéria-prima às áreas de prática da caça, pesca, coleta, 
à elaboração e emprego social do artefato (e sua reutilização) via escavações e análises físico-químicas (Alves, 1988, 1994,1997).

- Reconstituir as relações das populações dos sítios prospectados e escavados no nível da captação de recursos naturais com ecossistemas circundantes aos assentamentos;

- Musealizar a produção de conhecimentos advindos das pesquisas intensivas de campo, com a montagem de museus de arqueologia em parceria com as prefeituras municipais onde são realizadas as prospecções e escavações para preservar e divulgar junto ao público (local, regional, nacional e até internacional) a memória cultural do povoamento pré-colonial (Alves \& Furlaneto Ferreira, 2004; 79-80).

- Elaboração de textos explicativos do Museu de Arqueologia de Perdizes, em português e em inglês para atingir público internacional (via sites na Internet).

Até o presente, foram evidenciados e detectados dois horizontes crono-culturais no vale do Paranaíba: caçadores-coletores (correspondentes aos horizontes líticos do sítio Rezende, Centralina) e agricultores-ceramistas (sítios Prado, Silva Serrote, Inhazinha, Menezes, Rodrigues Furtado e estrato superior do Rezende).

Esta pesquisa dá continuidade aos outros trabalhos acadêmicos desenvolvidos no âmbito do projeto Quebra-Anzol: a dissertação de mestrado (1982) e de doutorado de Alves (1988), a dissertação de mestrado de Fagundes (2004) e de Medeiros (2007) sobre os vestígios líticos e cerâmicos dos sítios Inhazinha e Rodrigues Furtado (município de Perdizes), contribuições fundamentais para atingir um dos objetivoscentrais do projeto: compor um quadro crono-cultural dos assentamentos pré-coloniais e pré-históricos do vale do Paranaíba, inserido no espaço e no tempo (Mapa 1).

Seguem os dados dos sítios escavados no âmbito do projeto Quebra-anzol (Alves,1992):

a)sítios de populações agricultoras-ceramistas: 
- Prado: escavado em 1980,1981 e 1983. Está situado na Fazenda Engenho Velho no município de Perdizes-MG. Apresenta datações de $493 \pm 74$ anos AP(FATEC-SP) e $400 \pm 50$ anos AP. Foram executados três perfis estratigráficos, treze trincheiras, evidenciadas sete manchas escuras e realizadas três decapagens.

- Silva Serrote: escavado no ano de 1985.Localiza-se na Fazenda Serrote, no

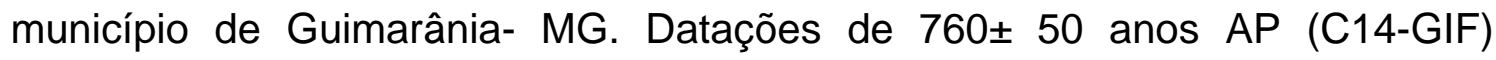
e790 \pm 190 anos AP (TL-FATEC). Foi executado um perfil estratigráfico, cindo trincheiras foram abertas, totalizando trinta manchas escuras evidenciadas, e duas decapagens executadas.

- Inhazinha: escavado em duas campanhas (julho e agosto) de 1988, situado na Fazenda Água Limpa, município de Perdizes-MG. Datação obtida de 1095ะ 186 AP (TL-FATEC-SP). Um perfil foi aberto, cinco trincheiras trabalhadas, quatro manchas escuras reveladas e uma decapagem de solo.

- Menezes: escavado no ano de 1991; situado na fazenda São Francisco de Borja, Perdizes-MG. Datado em 572 \pm 80 anos AP (TL-IF-USP). Um perfil estratigráfico foi aberto, executadas cinco trincheiras, quatro manchas escuras reveladas e duas decapagens realizadas.

- Rodrigues Furtado: escavado em julho e agosto de 1992 e em julho de 2006. Localizado na Fazenda Morro da Mesa, Perdizes-MG. Datação obtida de $500 \pm 50$ anos AP (TL-FATEC). Um perfil estratigráfico foi aberto, duas trincheiras foram abertas, foram evidenciadas quatro manchas escuras e duas decapagens de solo e a abertura de duas sondagens exploratórias.

b)sítios de agricultores-ceramistas (prospecção sistemática):

- Antinha: prospectado em 1980, localizado na Fazenda Barra, município de Perdizes-MG.(870 \pm 130 anos AP). 
- Pires de Almeida: prospectado em 1989, localizado na Fazenda da Ilha,

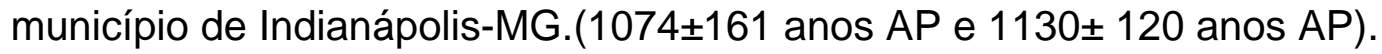

c)sítio de populações caçadoras-coletoras e agricultores-ceramista:

- Rezende: escavado em 1988, 1989, 1990,1991 e 1992; está situado na fazenda do Paiolão no município de Centralina-MG. Foram abertos dois perfis, doze trincheiras, foram evidenciadas nove manchas escuras e duas decapagens executadas. Este sítio á caracterizado por uma estratigrafia complexa; foi dividido em duas zonas:

Zona 1 estrato lito-cerâmico(3): 460 50 anos AP(TL-FATEC-SP) $480 \pm 50$ anos AP(TL-FATEC-SP) $721 \pm 100$ anos AP(TL-FATEC-SP) Estrato lítico (2):4250 50 anos AP(C14-GIF) Estrato lítico(1):4950 \pm 70 anos AP(C14-CENA-USP) Zona 2: estrato lito-cerâmico(5): 630 95 anos AP(TL-FATEC-SP) $830 \pm 80$ anos AP TL-FATEC-SP) $1108 \pm 166$ anos AP TL-FATEC-SP) $1190 \pm 60$ anos AP C14-CENA-USP)

Estrato lítico(4):5620 \pm 70 anos AP (C14-CENA-USP) Estrato lítico(3):6110 \pm 70 anos AP (C14-CENA-USP) Estrato lítico(2):6950 80 anos AP (C14-CENA-USP) Estrato lítico(1): $7300 \pm 80$ anos AP (C14-CENA-USP)

Durante estes 28 anos de pesquisas sistemáticas de campo relacionadas ao projeto arqueológico na região do alto do Paranaíba-MG, foi possível mapear alguns aspectos culturais e sociais destas populações extintas da região por meio dos vestígios materiais deixados por elas no registro arqueológico dos assentamentos escavados .

A intensa pesquisa acadêmica e crescente número de dissertações e tese possibilitou a composição de um panorama geral dos grupos que habitaram esta região: as populações nômades e sazonais praticavam a caça, coleta e pesca, confeccionavam artefatos como pontas de arremesso, raspadores, lesmas, objetos representativos de atividades caçadoras- 
coletoras como planos convexos(lesmas), raspadores, lascas corticais com e sem retoques e pré-pontas.

Os agricultores-ceramistas (populações semi-sedentárias) construíam aldeias, cujas estruturas habitacionais eram ovaladas (manchas escuras), conservavam o hábito de lascar a pedra, praticavam o polimento da pedra, confeccionavam cerâmica utilitária e funerária; alguns mortos eram predominantemente enterrados em posição fetal, em urnas de cerâmica lisa com tampa e secundariamente enterrados diretamente na terra e praticavam agricultura incipiente(Alves et alli, 2002).

\section{Mapa 1 - Sítios do projeto Quebra-Anzol:}

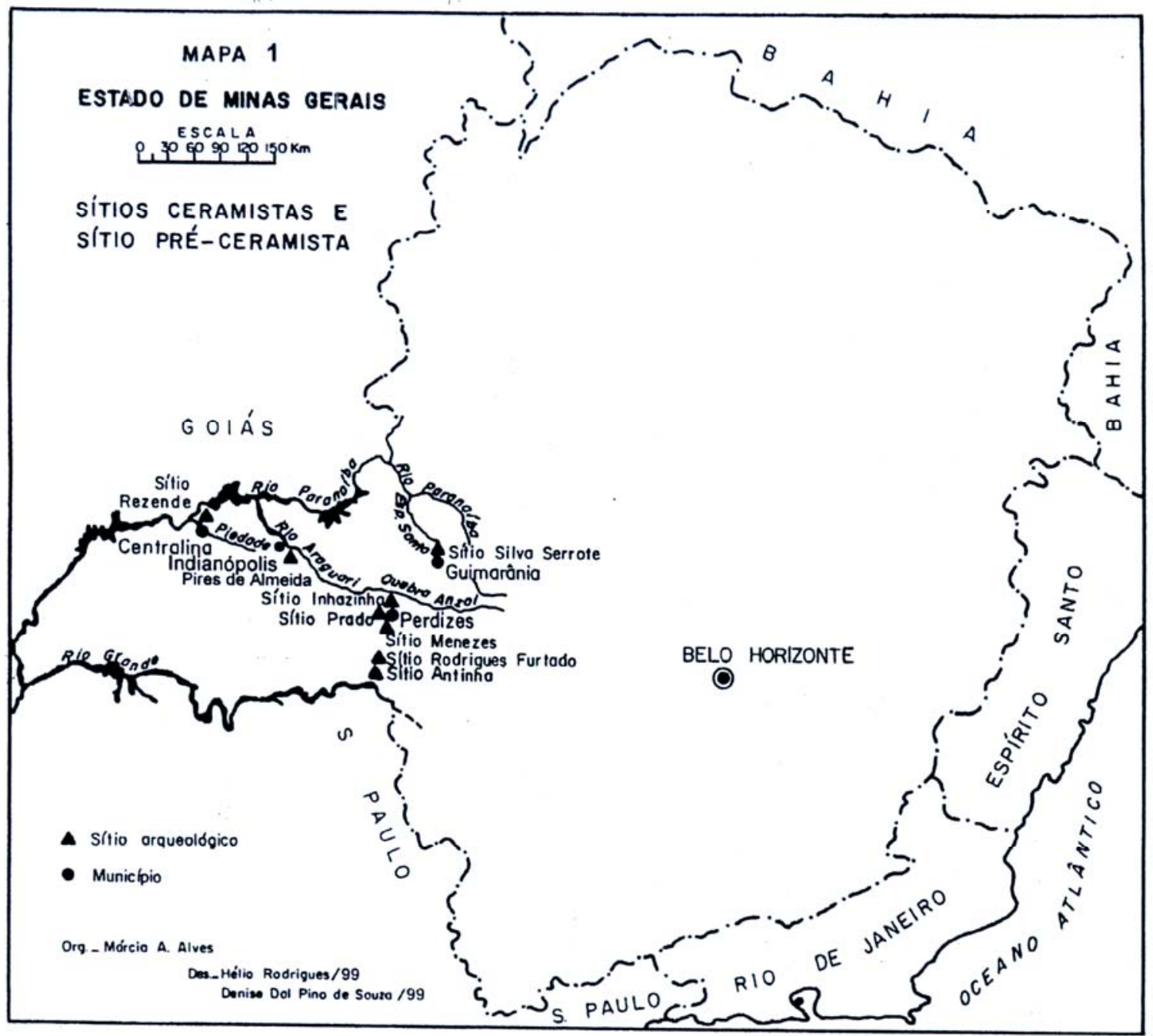

Fonte: Alves(1992) 
Desde os primórdios da confecção desta dissertação, dentre as problemáticas apresentadas, buscou-se identificar se a cultura material dos dois sítios analisados indicaria a ocupação de um único grupo cultural ou de grupos culturalmente distintos, considerando que as datações de ambos sítios revelam aproximação cronológica.

Para tanto, priorizamos o resgate da cadeia operatória de transformação das matériasprimas em artefatos, presentes no sítio Silva Serrote, bem como a detecção das cadeias operatórias da cerâmica e do lítico do sítio Menezes, com o auxílio da reconstituição dos vasilhames cerâmicos e da análise laboratorial, indicam habitus(ver página 29), que se refletem na escolha de matérias-primas, nos gestos que originam a diversidade de técnicas de lascamento, retoque e produção de artefatos líticos, de seleção de argila, de técnicas de montagem do utensílio cerâmico; todas estas etapas estão associadas ao emprego social do artefato nas esferas utilitária e simbólica.

Estas análises foram fundamentais para a descrição detalhada das características dos conjuntos líticos e cerâmicos e observação das recorrências e diferenças.

Dentre as correntes teóricas e existentes sobre a tecnologia, este trabalho acata a vertente de que este representa a materialização das técnicas socialmente aprendidas por estas sociedades extintas e carregam significação social e/ou simbólica desde o início de sua confecção. Para Mauss(1934, pg 342):

Técnica é o ato eficaz tradicional (este ato não se diferencia do ato mágico, do religioso ou do simbólico); é necessário que seja tradicional e seja eficaz. Não há técnica nem transmissão se não há tradição. O homem se distingue fundamentalmente dos animais por estas duas coisas, pela transmissão de suas técnicas e provavelmente pela sua transmissão oral.

Portanto para Mauss, todo ato humano carrega uma técnica tradicionalmente transmitida e o mesmo ocorre com o ato de confeccionar objetos.

Nesse sentido, a arqueologia, cujo objeto de estudo são os vestígios materiais, proporciona a partir do estudo da tecnologia de produção de artefatos, respostas a uma parte significativa da realidade social dos povos extintos e agráfos. 
Segundo Leroi-Gourham(1984a), quando se recua no passado, as fontes de informação etnológica se extinguem rapidamente, como por exemplo as tradições orais que morrem com a última geração que as transmitiu e a fontes de informação escrita são escassas; a cultura material produzida pelas populações extintas, derivada das técnicas da confecção de objetos, é o único documento que permite um recuo temporal maior no estudo de povos pré-históricos.

Seguindo essa linha de pensamento, o estudo da tecnologia envolvida na produção lítica e cerâmica dos sítios Silva Serrote e Menezes foi primordial para a apreensão das técnicas tradicionalmente transmitidas e caracterização de um "modo de fazer" dos grupos que habitaram estes sítios. Para o estudo da tecnologia e deste "modo de fazer", existe um conceito fundamental, utilizado neste trabalho: o conceito de cadeia operatória. Assim o descreve Lemmonier(1992 a e b) :

Describes the technological operations that bring a raw material from a natural state to a manufactured ne(...)

Desta forma, cadeia operatória envolve todo o procedimento tecnológico socialmente aprendido referente à transformação de um bem natural em um bem social.

O conceito de cadeia operatória leva à discussão de um outro conceito: o de estilo tecnológico. O proceder tecnológico, reproduzido pela transmissão oral das técnicas, escolhidas e desenvolvidas dentro de diversas possibilidades que o corpo humano está apto a executar, assim como as escolhas feitas relativas à fontes de matéria-prima, local e técnicas, que são particulares de cada grupo e que caracterizariam o "estilo tecnológico".

A discussão acadêmica sobre estilo tem sido intensa há alguns anos; no entanto, existe num consenso geral sobre algumas características que definem "estilo"; este, remetese às escolhas feitas pelo artesão durante a cadeia operatória e que podem caracterizar ou não um estilo próprio, ou seja, uma expressão cultural característica de determinado grupo.

O estilo é particular a cada grupo cultural, ou seja, é o modo como as pessoas realizam seu trabalho, incluindo as escolhas feitas por eles no que se refere aos materiais e às técnicas de produção (Reedy \& Reedy, 1994, in: Dias, S. ;Silva, F.A., 2001). 
Nesta dissertação, trabalhamos apenas com a análise tecno-tipológica da cadeia operatória lítica e cerâmica dos sítios Silva Serrote e Menezes. Esta análise proporcionou a identificação de alguns aspectos da cultura, que, juntamente com as datações absolutas, as análises laboratoriais e a reconstituição dos vasilhames cerâmicos, indicaram características recorrentes que contribuirão para o quadro crono-cultural das populações pré-coloniais do vale do Paranaíba-MG, atingindo o objetivo primordial do projeto Quebra-Anzol que é o estudo da dinâmica cultural, centrado na análise da cultura material contextualizada.

Em todo o mundo, o material lítico pode ser considerado o vestígio arqueológico mais abundante encontrado em sítios pré-históricos. Esta afirmativa é decorrente de diversos fatores: o lítico resiste a perturbações no solo de origem antrópica e natural. Artefatos de materiais orgânicos são facilmente deterioráveis e suscetíveis às condições climáticas.(Vilhena-Vialou, A,1980; Morais,J.L,1983; Tixier,1980,).

Essa resistência e conseqüente recorrência apresentada por este tipo de vestígio torna os seus estudos mais complexos: a variabilidade dos artefatos reflete diretamente a variabilidade cultural dos povos que os produziram.

O homem conseguiu dominar um dos materiais mais difíceis de se transformar: a rocha. Cada gesto aplicado à matéria e que envolve a confecção de um artefato implica num comportamento que reflete uma parte de uma realidade social. A busca de fontes de matériaprima em lugares distantes, o desenvolvimento das técnicas de redução (lascamento, talhamento , retoque e etc..) para atender necessidades da vida social como raspar, cortar, descarnar, fender, incisar dentre outras que caracterizam um modo de vida e uma economia pré-histórica(Vilhena-Vialou,A.1980).

A produção da cerâmica é ainda mais complexa: a cerâmica permite a satisfação de necessidades econômicas básicas como o armazenamento e transporte de alimentos e água, como também atende às necessidades de expressão do universo ritual e simbólico, educacional, social e de identidade grupal, como por exemplo, a produção de urnas funerárias, de cuscuzeiros para transformação do alimento, confecção fusos para atender à necessidade de produzir vestes etc...

Inicialmente, o estudo das cadeias operatórias teve início apenas com os objetos e artefatos líticos; a partir do desenvolvimento do conceito, este passou a ser utilizado para estudar o processo de produção da cerâmica, e de outros vestígios arqueológicos (BALFET,H, 1991; LEMMONIER, P. 1992) 
O estudo das cadeias operatórias não é centrado no objeto, mas sim na reconstrução dos comportamentos sociais que este proporciona. Para esta reconstrução, é necessário que o objeto esteja devidamente contextualizado no momento do registro visual do solo arqueológico durante a escavação, pois a interpretação dos artefatos só pode ser feita em relação ao modo como um sítio foi escavado: as decapagens, os perfis, os cortes e as trincheiras, com o objetivo de delimitar o que o estudo do material irá caracterizar (Vilhena Vialou, 1980). Nesse sentido, a presença de outros vestígios arqueológicos em associação aos artefatos, podem caracterizar diferentes atividades ou funções sociais.

Além das funções mais triviais, os objetos líticos também adquirem uma complexidade no seu uso, pois devido a sua longevidade um artefato lítico pode ter sido inicialmente feito para uma função, descartado, transportado para outro contexto social, reutilizado para outra função, descartado uma segunda vez, reutilizado e assim sucessivamente. Todos estes usos e reusos geram marcas nos artefatos que são reconhecíveis pelo arqueólogo; a partir do contexto arqueológico, pode-se caracterizar o seu uso na época correspondente ao nível em que foi encontrado, e as outras marcas deixadas pelos usos anteriores serão analisadas como seqüências de operações da cadeia operatória que envolve este objeto. Muitos gestos que envolvem a confecção de um artefato em pedra foram compreendidos por meio da Arqueologia Experimental.

\section{Retorno social do Projeto Quebra-anzol-O Museu de Arqueologia de Perdizes}

O Projeto Quebra-Anzol cumpriu um de seus objetivos principais junto ao IPHAN e à comunidade: a criação de um Museu na cidade de Perdizes - MG, veículo de retorno social do investimento público, aplicado nas escavações e trabalhos acadêmicas deste projeto. Além da preocupação acadêmica, o projeto Quebra-Anzol é representado por um museu comprometido com a extensão deste conhecimento à população residente na região.

Localizado no centro da cidade de Perdizes - MG, o Museu de Arqueologia foi o primeiro museu instaurado na cidade no ano de 1986, pela Profa. ${ }^{2}{ }^{a}$. Márcia Angelina Alves ${ }^{1}$ e leva o nome desta pesquisadora. Em 2002 foi inaugurada a exposição de longa duração "Povoamento Pré-Histórico do Vale do alto do Paranaíba-MG". Em 2002, o Museu foi criado

\footnotetext{
${ }^{1}$ Sugestão do prefeito municipal Sr. Prof.João Custódio da Silva da gestão de 1983-1988, com aprovação da câmara municipal.
} 
legalmente, sob responsabilidade administrativa da Prefeitura $^{2}$, lei 1388/2002, e com previsão orçamentária mensal para manter o aluguel, água, luz, um auxiliar de serviços gerais e um funcionário para a monitoria.

O acervo é composto de peças arqueológicas coletadas nos sítios escavados pelo projeto Quebra Anzol. O Museu Municipal de Arqueologia de Perdizes é composto de duas pequenas salas de exposição, uma sala para reserva técnica e laboratório improvisado, um banheiro e uma copa (Fotos 1 e 2).

A realidade do Museu Municipal de Arqueologia de Perdizes é semelhante à de vários outros museus brasileiros: dificuldades orçamentárias e falta de sede própria, dentre outros problemas que remetem diretamente à questão da identidade coletiva e da valorização do patrimônio cultural. A cultura material arqueológica brasileira é produto da vivência de populações indígenas extintas, sociedades historicamente marginalizadas pelos colonizadores. Quando determinado objeto é qualificado como patrimônio, implica-se na escolha de determinado bem cultural para representar um grupo e geralmente, o patrimônio escolhido para as representações é o bem cultural pertencente e produzido pelos grupos das classes sociais dominantes.

O patrimônio das sociedades indígenas extintas é representado pelos vestígios arqueológicos e a imagem de desvalorização social dos grupos indígenas perante os brasileiros é resultado do processo de exaltação da trajetória européia no Brasil e reforçado pelo sistema educacional oficial.

O museu é o comunicador da produção científica e a exposição é o canal de comunicação com o público; sua posição teórico-metodológica, política, moral e histórica, bem como seu contexto administrativo refletem diretamente no discurso apresentado pela exposição.

O Museu de Arqueologia de Perdizes foi aberto a partir do esforço da pesquisadora coordenadora do projeto Quebra-Anzol, de sua articulação com autoridades e residentes locais na tentativa de conseguir um espaço para abrigar o material proveniente das escavações da região do vale do Paranaíba. Estas dificuldades podem ter sido enfrentadas em decorrência do status da arqueologia pré-colonial no país, que muda gradativamente graças a projetos como este, que priorizam ações educativas com a comunidade.

Este museu foi montado de acordo com os princípios da escola francesa de arqueologia (inaugurada por Leroi-Gourhan) em que o estudo da cultura material é

\footnotetext{
${ }^{2}$ Gestão do prefeito Alcides Flausino Dias, administração 2001-2004.
} 
fundamental para o estudo de fenômenos de sociedades extintas e que se relacionam com as sociedades do presente; os objetos arqueológicos compõem a evidência física do passado e sua relação com as sociedades do presente é fundamental para que o vestígio material seja veículo de memória e, portanto do supracitado retorno social da pesquisa acadêmica.

O Museu de Arqueologia de Perdizes possui monitoria e recebe escolas de toda a região. Além do trabalho com a comunidade, a cidade de Perdizes está inclusa no circuito de municípios ligados à atividade turística no Parque Nacional da Serra da Canastra, sob a coordenação da cidade de Araxá, fato que traz novas perspectivas econômicas e sociais para o município.

A melhoria das instalações do museu proposta à prefeitura e a ampliação do acervo qualificam o Museu de Arqueologia como atrativo turístico ${ }^{3}$ potencial, e, aliado aos outros atrativos presentes na cidade, podem impulsionar o Turismo Cultural.

O Turismo Cultural é um meio funcional de comunicação entre os acadêmicos e a população. O benefício dessa inter-relação é mútuo (Alves e Furlaneto, 1999), pois os arqueólogos têm os seus trabalhos valorizados e integrados a um contexto de responsabilidade social.

Morais (2001, in: Funari, P.P \& Pinsky, J; p.99) apóia esta interface entre o Turismo, a arqueologia e a preocupação no que concerne à comunicação com o público em geral:

A função social do Turismo é o principal argumento para o uso do patrimônio arqueológico para fins turísticos(...) a inclusão do patrimônio arqueológico no elenco das potencialidades de uso turístico pelo município deverá ser precedida de legislação específica que determine inclusive as garantias quanto à sua proteção e preservação, porque a herança arqueológica indígena interessa ao povo brasileiro como nação, superando os interesses locais circunscritos nos limites de um único município.

\footnotetext{
${ }^{3}$ Todo lugar,objeto ou acontecimento de interesse turístico que motiva o deslocamento de grupos humanos para conhecê-los.(BENI, 2002)
} 
Foto 1 - Exposição do Museu de Arqueologia de Perdizes

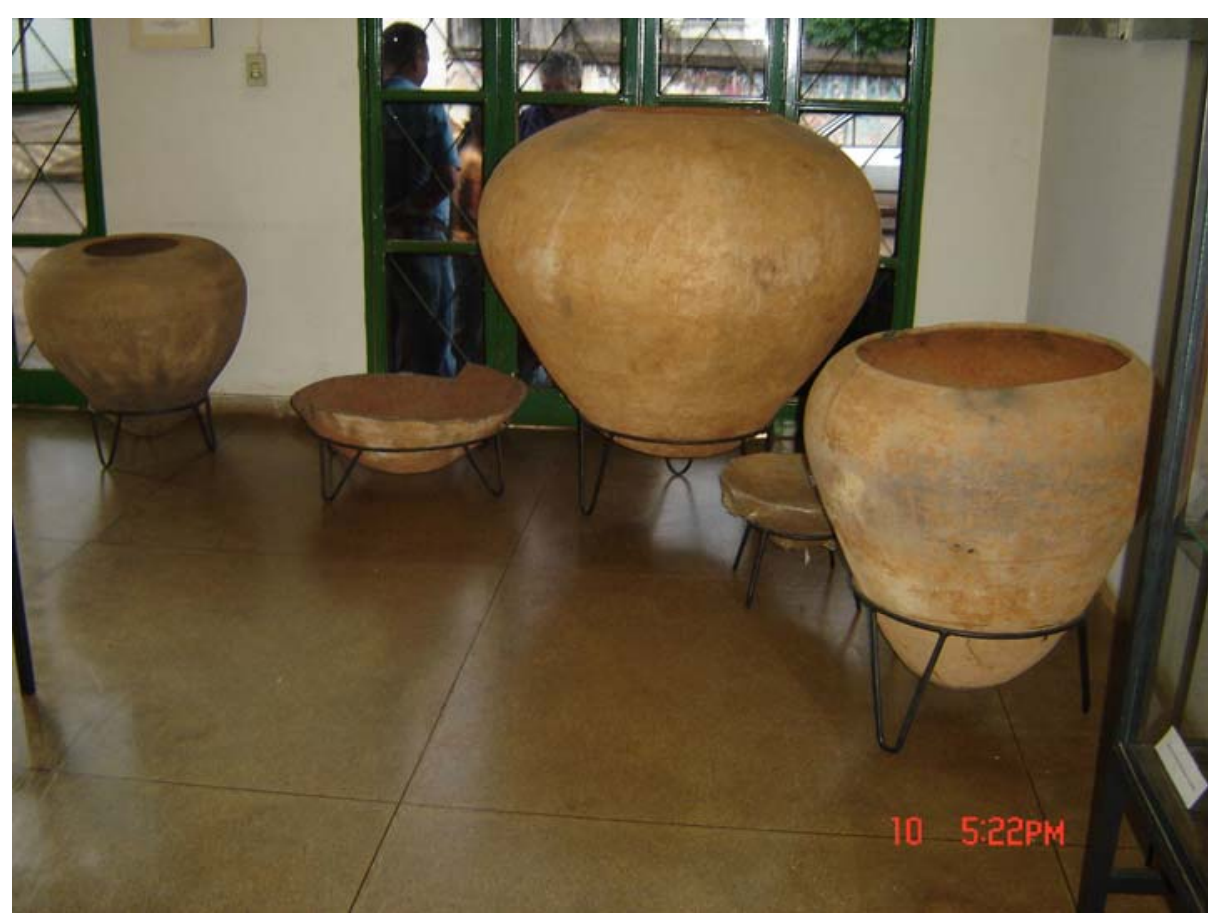

Foto:Figueiredo, 2008.

Foto 2: Sala 1 - Exposição do Museu de Arqueologia de Perdizes

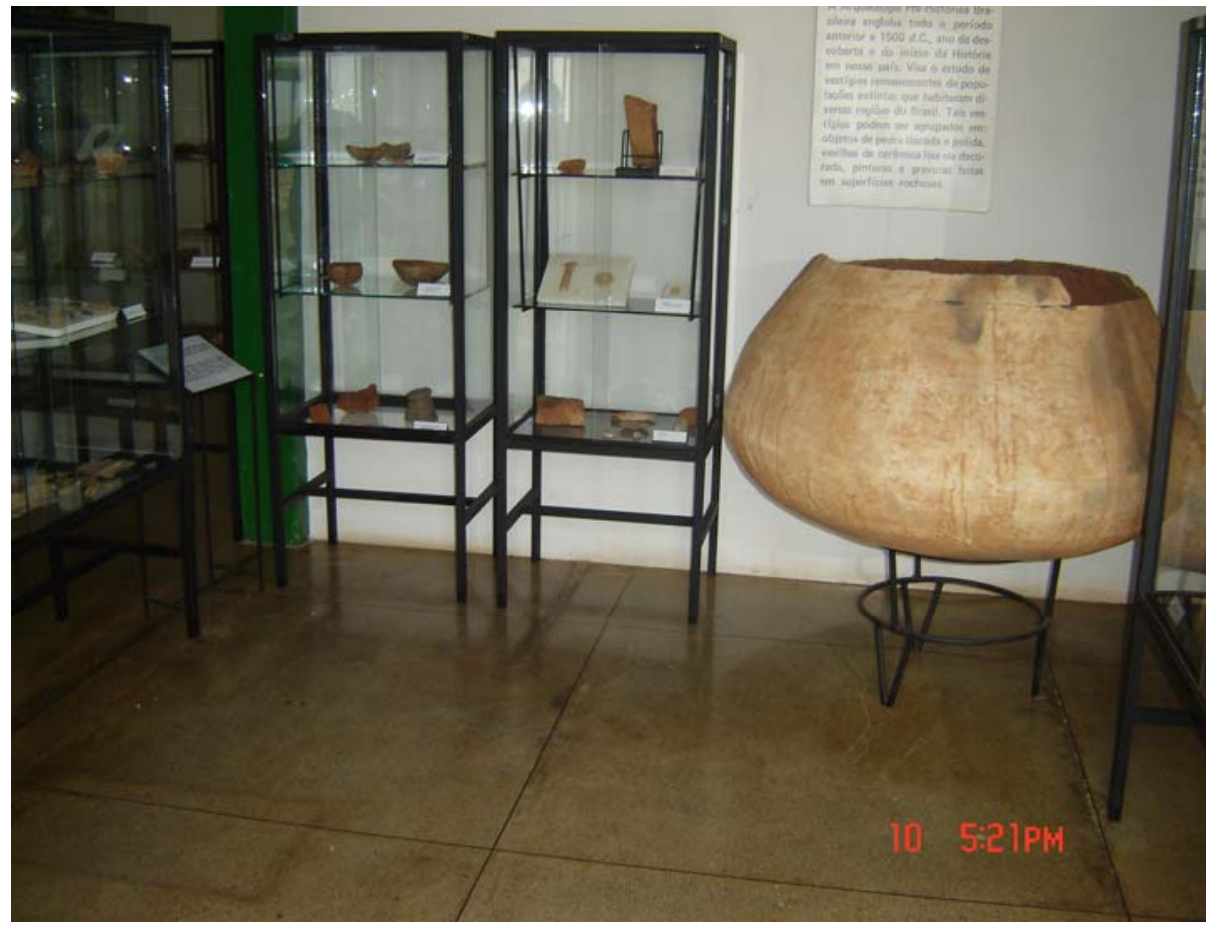

Foto:Figueiredo,2008. 


\section{Objetivos:}

Gerais:

Dentre os objetivos gerais, buscou-se a recuperação do procedimento de transformação dos bens naturais (rochas e argila mineral) em bens sociais (artefatos líticos e vasilhames cerâmicos), associados às cadeias operatórias da cultura material lítica e cerâmica: a escolha das fontes de matérias-primas, técnicas de confecção, uso e descarte.

A reconstituição deste procedimento de produção da cultura material lítica e cerâmica dos Sítios Silva Serrote e Menezes proporcionou a indicação de permanências tecnológicas na cultura material.

\section{Específicos:}

Como objetivo específico, buscamos identificar e comparar as fontes de matéria-prima (litológicas e argilosas) em ambos os sítios; verificou-se a proximidade das fontes em relação ao assentamento e seu possível uso na confecção dos objetos.

Quanto às técnicas, vislumbramos a caracterização os gestos técnicos empregados, por meio da análise das técnicas de confecção para a identificação de inovações ou mudanças tecnológicas no intento de definirmos um padrão (recorrência) tecnológico.

Por meio da identificação tecnotipológica, analisou-se a semelhança dos sítios em questão com a cultura material da tradição Aratu-Sapucaí, classificação atribuída pelo PRONAPA ${ }^{4}$.

${ }^{4}$ A área de pesquisa foco desta dissertação, de acordo com a sistematização do PRONAPA (Programa Nacional de Pesquisas Arqueológicas foi inserida no contexto da Tradição Aratu-Sapucaí. Este programa, que concluiu seus relatórios em 1980, definiu várias "tradições" diferentes para designar fenômenos semelhantes, fato que ocorreu, pois, cada pesquisador atuou em um estado, e produzindo relatórios distintos e que foram discutidos após a data de conclusão do Programa; após estas discussões, houve um consenso sobre a necessidade de unificação das antigas tradições Aratu, Uru e Sapucaí. (Prous, 1992; Martin,1996):

Dentre as principais características que compõem esta tradição, algumas são recorrentes: a Tradição Aratu Sapucaí ocupava terrenos de superfícies vastas, promoviam a formação de grandes aldeias, sempre próximas a pequenos córregos e longe dos grandes rios; a indústria cerâmica não possui decoração (às vezes banhos vermelhos); há produção intensa de vasos grandes com cacos espessos, pequenos vasos duplo/geminados e urnas funerárias piriformes (Martin,1996;Prous,1992 ).

Sobre as tradições que culminaram na Tradição Aratu-Sapucaí

Tradição Aratu-Bahia

A maioria dos sítios conhecidos estão localizados no recôncavo baiano. A data mais antiga atribuída a toda a Tradição é $400{ }^{\mathrm{a}} \mathrm{D}$. O ambiente de preferência eram as encostas de morros ou imediações do mangue. 
As ocupações atingiam até $500 \times 200 \mathrm{~m}$ de extensão. Estes terrenos eram marcados pela existência de fundos de habitações, cabanas de $10 \times 15 \mathrm{~m}$ de diâmetro, caracterizadas por uma grande espessura de camada arqueológica, alinhadas em círculo ao redor de uma praça central.

A cultura material é representada por numerosas urnas funerárias; piriformes, globulares, em média com $75 \mathrm{~cm}$ de altura, $65 \mathrm{~cm}$ de comprimento e abertura de $45 \mathrm{~cm}$; algumas urnas possuem tampas.

O Mobiliário funerário é com posto de pequenos machados polidos, rodelas de fuso, tigelas.

A cerâmica geralmente não é decorada, o tempero é areia mais ou menos fina, às vezes apresenta grafita. Há a produção de tigelas hemisféricas com bordas onduladas, rodelas de fuso discoidais e cachimbos. De acordo com Prous(1992) e Martin(1996), a configuração desta tradição assemelha-se ao padrão de aldeamento Kaiapó( dupla linha de casas: praça central homens e casas périféricas mulheres-matrilocal.

Tradição Goiás (antiga tradição Uru)

Representada pela Fase mossamedes(assemelha-se ao padrão de aldeamento Kaiapó( dupla linha de casas: praça central homens e casas périféricas mulheres-matrilocal formando círculos ao redor de uma grande praça); identificada geralmente na parte superior de vertentes setentrionais de morros, cabeceiras de rios.

Quanto à produção da cultura material cerâmica, utilizava-se como antiplástico o cariapé(vegetal); presença de cachimbos angulares, base perfuradas e vasos duplos geminados pequenos e de carimbos cilíndricos para a pintura corporal. As rodelas de fuso encontradas eram chatas ou companiformes e há em alguns sítios cerâmica intrusiva tupi.

A tradição é marcada pela escassez de material lítico.

Tradição em Minas Gerais e no Mato Grosso (Sapucaí))

A Localização destes sítios é recorrrente em regiões colinares, perto de rios (meia encostas de elevações suaves ou terraços); as ocupações atingiam até 500 metros em ampla superfície. Quanto à indústria cerâmica, os vasos são grandes e com cacos espessos. As urnas funerárias são globulares e não piriformes, com mais de um metro de diâmetro de bojo. São recorrentes alguns vasos pequenos, de paredes finas e bases perfuradas (cuscuzeiros); os cachimbos são tubulares.

A maioria das peças é sem decoração e há alguns cacos com banho vermelho que pode ser aplicado em qualquer tipo de recipiente. O antiplástico apresenta arenito moído, cujos grãos deixados na superfície a tornam com aparência de lixa.

Todos os sepultamentos são feitos em urnas, às vezes com tampas e placas de pedra, com cacos e machados no interior, eventualmente rodeadas por recipientes menores.

Quanto à produção lítica, são encontrados machados polidos de talão picoteado e seção biconvexa. Alguns possuem forma semilunar. Há poucas lascas, geralmente não retocadas. Há martelos cilíndricos picoteados, com sulco central para encabamento. 


\section{Estrutura da dissertação de mestrado}

O capítulo 1 versa sobre o referencial teórico e metodológico acerca do conceito de tecnologia e de cadeia operatória, bem como das escolhas culturais envolvidas durante a produção da cultura material lítica e cerâmica.

O capítulo 2 concerne às questões do meio ambiente, cenário onde se desenvolveram as atividades da produção material destes grupos da região do Vale do Paranaíba: geologia, geomorfologia, vegetação, hidrografia clima e solo.

O detalhamento da ambientação revela os recursos disponíveis como destaques de fontes de matérias-primas.Neste capítulo também apresentaremos as pesquisas de campo e os contextos evidenciados nos sítios Silva Serrote e Menezes, ou seja, as estruturas de habitação, combustão, e sepultamentos evidenciados pelas pesquisas de campo e o método utilizado nestas escavações.

O capítulo 3 descreve a análise tecnológica da indústria lítica, a ficha tecnotipológica utilizada para a classificação desta indústria, matérias-primas utilizadas, e as escolhas mais recorrentes referentes às técnicas.

O capítulo 4 revela os instrumentos de análise tecnológica da indústria cerâmica, baseada na ficha tecnotipológica de classificação das técnicas de manufatura: acabamento de superfície,decoração plástica, espessura da parede, cadeia operatória e seu uso social.

O capítulo 5 apresenta as análises técnicas das lâminas petrográficas do sítio Menezes e a reconstituição dos vasilhames.

O capítulo 6 é composto pelas considerações finais e apresentam a interpretação geral dos dados, embasada nos conceitos e métodos apresentados. 


\section{Capítulo 1: Referencial teórico e metodológico}

Optamos por empregar no estudo tecnológico dos vestígios líticos e cerâmicos desta dissertação os conceitos de cadeia operatória (escola francesa) e estilo (escola norteamericana). Entretanto, no decorrer do estudo das indústrias líticas e cerâmicas do Silva Serrote e Menezes, verificamos que não havia variabilidade artefatual para empregar 0 conceito de estilo, na perspectiva funcionalista de Binford e na simbólica de Sackett. Dessa forma, o nosso estudo está centrado nas cadeias operatórias dos vestígios cerâmicos e líticos em questão e o estilo será abordado de forma complementar e como possibilidade de trabalho para pesquisas futuras.

\subsubsection{Referencial teórico: a Antropologia das técnicas e o conceito de cadeia operatória:}

Segundo Mauss $(1935,1979)$, em sua obra sobre as técnicas corporais, anuncia que todas as ações do homem sobre o mundo material (ou não) são consideradas técnicas corporais, e conseqüentemente, em qualquer sociedade, os homens, fazem uso de seu corpo de uma forma tradicional. Os processos mentais que originam a reprodução de comportamentos observados pelos indivíduos são estimulados pela tradição do grupo em que estes foram endoculturados; estes processos revelam sobre o aprendizado do homem, num determinado tempo e espaço. Mauss (1974), acrescenta que o indivíduo reproduz movimentos que foram bem sucedidos de atos executados na sua frente ou com ele pela tutoria de outros e que estes atos serão perpetuados pelo grupo por várias gerações por meio da transmissão oral .(tradicionalidade, habitus).

Nesse contexto, o autor explana sobre a natureza social do conceito de habitus:

Durante muchos años he pensado sobre esta Idea de la naturaleza social del habitus(...) la palabra traduce mucho mejor que "costumbre", el "exis", lo "adquirido" y la "facultad" de Aristóteles (...).La palabra no recoge los hábitos metafísicos, esa misteriosa memória, tema de grandes volúmenes o de cortas y famosas tesis. Estos hábitos varían no solo com los indivíduos y sus imitaciones, sino sobre todo con 
las sociedades, la educación, las reglas de urbanidad y la moda. Hay que hablar de técnicas con la consiguiente labor de la razón práctica colectiva y individual; allí donde normalmente se habla del alma y de sus facultades de repetición(Mauss,1934, pg.340).

A partir deste conceito, Mauss insere o universo das técnicas como parte do habitus, ou seja, das práticas socialmente transmitidas(adquiridas).

Para este autor, as técnicas corporais e os gestos são abordados em uma concepção de aprendizado que é tridimensional; durante a internalização e cognição dos processos, contribuem os sistemas sociológico/psicológico, fisiológico e simbólico (estes sistemas compõem o fato social total). O aprendizado seria desta forma, embebido de significados, atribuídos graças ao sistema simbólico de cada sociedade.

O corpo é o primeiro instrumento, e que desta forma habilita o indivíduo fisiologicamente (fisicamente e cognitivamente) para a reprodução das técnicas. O uso final lemprego social direciona o gestual e as técnicas escolhidas; no entanto, a produção material está carregada de significação simbólica; a definição de "como fazer" e "utilizar" está imbricada em motivos de diversas origens, que podem ser de ordem prática (acerto e erro, relacionados ao desempenho otimizado do objeto) ou de razões êmicas de identidade étnica, divisão social, moralidade, crença/rituais e que caracterizam um universo simbólico único de cada grupo. Considerando este contexto, as ações do homem sobre a matéria estão relacionadas com estas diversas representações que compõem a lógica interna de cada grupo.

Leroi-Gourhan, discípulo de Mauss, prosseguiu o mestre no estudo das técnicas, e compõe relevantes obras acerca do tema; considera o testemunho das técnicas precioso, pois, cosidera a produção tecnológica como aspecto da vida social que evidencia uma continuidade total no tempo, permitindo o acompanhamento dos atos humanos; este autor enfatiza que a análise deve recair também sobre a atividade (ato) e não somente sobre o objeto em si. Leroi-Gourhan inventariou em sua obra "Evolução e técnicas, o homem e a matéria"(Leroi-Gourhan 1971) aproximadamente 40.000 fichas de conjuntos técnicos, considerando fatos como as limitações das propriedades dos materiais, e compôs um modelo, de tendências e fatos que culminaram em um modelo de estruturas técnicas das sociedades humanas. 
Nesse ínterim, a exaltação científica das técnicas impulsiona o estudo das cadeias operatórias e surge como uma alternativa de resgate do processo produtivo de vestígios materiais, que tem início desde a escolha da matéria prima, do local de confecção, das técnicas empregadas, de seu emprego social, de sua manutenção e descarte, sempre envolvidos no universo simbólico destas sociedades.

O conceito de cadeias operatórias surge de fato, com a composição da obra "O gesto e a palavra"(Leroi-Gourhan,1983), e que proporcionou a continuidade do estudo das técnicas proposto em sua obra anterior.

Leroi-Gourhan conceitua a técnica como gestos e ferramentas organizados em cadeias, aprimorou o modelo de visão tridimensional de Mauss, e o estendeu às técnicas metodológicas de pesquisas de campo (utilizadas neste trabalho).

Pierre Lemonnier, sucede Leroi-Gourhan ; critica que os estudos contemporâneos sobre tecnologia recaem sobre os efeitos dos sistemas tecnológicos na sociedade (era do computador), sobre o que os homens comunicam quando produzem e usam artefatos ou até mesmo sobre as investigações acerca do estilo. Lemmonier retoma o estudo das técnicas corporais como processos que revelam sobre o sistema simbólico, afirmando que uma técnica aparece como forma de se atingir determinado objetivo físico e de coerência de significado material, sendo que vários significados podem ser atribuídos para uma técnica em particular (Lemonnier, 2001, pg 03).

Para este mesmo autor, a tecnologia é uma parte da realidade social, ou seja, o sistema tecnológico de determinada sociedade é um subsistema de um sistema maior denominado sociedade.

Lemonnier(1992) descreve a cadeia operatória como sendo um seqüência de operações tecnológicas que incidem sobre a matéria-prima bruta, tranformando-a de seu estado natural a condição de objeto manufaturado (bem social).

Dentre as influências do sistema simbólico, no desenvolver da cadeia-operatória está a questão da escolha. Como visto neste capítulo, as técnicas e o proceder são socialmente transmitidos e as escolhas culturais e individuais estão presentes durante toda a cadeia de operações.

Ademais de outros fatores que influenciam as escolhas, a questão do emprego social influencia diretamente no desempenho desejado para cada objeto (Schiffer and 
Skibbo,1997). O desempenho, também definido como performance, está relacionado com os atributos finais, considerados ideais para cada objeto. Estes autores propõem que algumas técnicas ou ingredientes podem ser adicionados durante o processo com o objetivo de alcançar estas finalidades premeditadas(podem ser físicas ou simbólicas).

\subsubsection{As etapas da cadeia operatória :}

Procura, obtenção e transporte de matéria-prima:

Nessa primeira etapa da análise, busca-se inventariar as disponibilidades das possíveis fontes de matéria-primas, localizadas na região dos sítios (fontes argilosas e litológicas), no intento de determinar quais materiais podem haver sido transportados para os sítios, quais materiais foram introduzidos, qualificando desta forma o papel de cada matériaprima em um dado sistema tecnológico, lítico ou cerâmico(Sellet,1998).

O mapeamento das fontes argilosas e litológicas é fundamental para o estudo comparativo dos artefatos finais e possíveis fontes; a distância das fontes em relação aos assentamentos também contribui para este estudo; geralmente as distâncias são usadas para inferir o tipo de obtenção(obtenção direta ou troca). O cruzamento de informações entre a localização das possíveis fontes e do local de atividade ou trabalho definem a condição do deslocamento.

Dean Arnold em 1985 (in: Schiffer and Skibo,1997), realizou estudos sobre as distâncias para a busca da argila e do tempero em sociedades contemporâneas não industriais ; em uma amostra de 111 sociedades, ele encontrou os seguintes resultados:

- 33\% dos casos, a argila explorada estava localizada a 1 kilometro de distância e em 84\% a argila explorada estava localizada até $7 \mathrm{~km}$ de distância.

-Quanto ao tempero ou antiplástico, em 52\% dos casos, a distância alcançada para obtenção do tempero foi de 1 kilômetro ou menos, $97 \%$ dos casos o tempero era obtido em até $9 \mathrm{~km}$ de distância.

\section{Processo de manufatura}

Nesta etapa, busca-se caracterizar as técnicas de manufatura empregadas nos artefatos; no caso dos líticos, analisam-se as técnicas da seqüência de redução dos artefatos e as ferramentas utilizadas para a execução cada técnica; quanto ao processo de 
manufatura da cerâmica, podemos considerar as técnicas de montagem, adição de temperos, atribuição da forma, acabamentos, tipo de queima e de decoração plástica.

Quanto à análise das técnicas, devemos priorizar a análise dos micro- traços(Karlin, Bodu, Pelegrin,1991) de um artefato e as técnicas de redução, pois algumas técnicas como, por exemplo, o retoque, que pode indicar reativação de um gume e, portanto manutenção de um artefato previamente criado. Para tanto são analisados os produtos e os subprodutos de uma redução.

Uso, manutenção e descarte dos objetos.

Esta parte da análise provém da interpretação dos dados, obtidos pelo contexto arqueológico dos objetos, imprescindível para inferir o uso social de cada artefato. Faz-se necessário contextualizar o ambiente em que objeto foi encontrado e sua proximidade com as estruturas habitacionais, sepultamentos, fogueiras, bolsões de lascamento etc...

\subsubsection{A variabilidade artefatual}

Desde as primeiras classificações artefatuais que surgiram entre os arqueólogos, uma das problemáticas relevantes levantadas por estes cientistas foi a causa da infinita variabilidade artefatual encontrada no tempo e no espaço. Portanto, a observação desta variabilidade está relacionada com a necessidade de classificar estes objetos, na busca de uma situação ideal de formar coleções que pertencessem aos mesmos grupos culturais.

As primeiras classificações utilizavam atributos como espaco-tempo (seriação). As mudanças artefatuais que as coleções apresentavam eram tidas como "evolução" de determinada técnica. Schiffer e Skibo(1997), afirmam que com a advento da arqueologia behaviorista e processual, a busca de explicações para a variabilidade artefatual tornou-se uma prioridade; os autores atribuem como causas desta variabilidade o conhecimento e a experiência do artesão. Em outras palavras, o artesão possui determinado conhecimento sobre as alternativas de confecção e materiais (ex. tipo de instrumento a ser usado, pigmentos, argila etc..) e de uso dos artefatos que influenciam nas escolhas técnicas que este faz, ou seja, a variabilidade artefatual seria causada pelos artesãos, que executam seqüências comportamentais diferentes em busca de material, do preparo e da manufatura do mesmo(busca, manufatura, uso e manutenção). Os artefatos produzidos por diferentes atividades seqüenciais de comportamento interferem no design e a definição do design é 
feita de acordo com a performance, logo, as escolhas técnicas estariam diretamente relacionadas com o tipo de performance (ou de desempenho) esperado dos objetos. A performance é o conjunto de demandas esperadas de determinado artefato como, por exemplo, o uso, a função, a distribuição, papel social de quem irá utilizar o objeto, se este terá de ser transportado ou carregar mantimentos, água, etc...

A performance, desta forma, determina as escolhas (comportamento-Arqueologia Behaviorista). Para cada tipo de artefato, espera-se determinado desempenho, que é importante para o grupo ou para o artesão. Alguns autores não aceitam a dicotomia "estilo X função", porque consideram que as escolhas feitas pelo artesão refletem na verdade toda uma série de atributos que compõem uma categoria de performance que é esperada pelo grupo. Não há discussão se estas escolhas são conscientes ou não, pois em determinado momento dessa tradição oral, estas escolhas foram feitas por meio da experiência empírica e a escolha dos atributos foi feita, de acordo com as condições ideais de desempenho ditadas pelo grupo(êmicos).

Busca-se compreender os tipos de interação ou atividade que estão implícitos em uma seqüência de atividades (ou seqüência comportamental). Uma atividade consiste em um padrão de interações entre os elementos (pessoas, artefatos, animais, ou seja, qualquer tipo de transmissão de energia física, química, térmica, visual, acústica entre esses agentes; a idéia é isolar e analisar as atividades que afetam o design final.

As escolhas técnicas usualmente têm efeitos tangíveis nas propriedades formais dos artefatos e como determinados artefatos que são encontrados no registro arqueológico (ex. indústria lítica e cerâmica) possuem características que são gerais. Schiffer e Skibo,(1997) , propuseram um modelo de "princípios correlatos". Este modelo consiste na montagem de uma matriz de atributos formais utilizados na confecção do artefato e o resultado final do emprego deste atributo, que pode ser empiricamente observado na peça, como por exemplo: análise de granulometria, correlacionando o tamanho dos grãos à rapidez de secagem na peça, ou ao tempo de queima; outro exemplo seriam os vasos feitos com fibra vegetal que são mais porosos e mais portáteis que os feitos com areia.

Uma única característica de performance (desempenho) influencia na propriedade formal do objeto, e esta, por sua vez, pode ser afetada por diversas escolhas técnicas. 
Este modelo supracitado de análise dos atributos formais dos objetos, assim como outros, atendem à uma necessidade que é comum a todo acadêmico, a de classificar. As classificações em arqueologia são necessárias principalmente para que haja comunicação entre as pesquisas, e para que os materiais já analisados sejam comparáveis entre si, ou seja, as tipologias são indispensáveis no diálogo entre os arqueólogos. Whitaker, Caulkins e Kamp (1998), observam que é preciso estar atento aos métodos que são utilizados nas tipologias de comparação; é preciso ter em vista que as classificações são categorias de análise (rótulos), feitas a partir do ponto de vista do pesquisador, diferentes do modo de classificar da categoria êmica (do grupo). Portanto, a dificuldade em classificar do arqueólogo que trabalha com material de grupos extintos é que este pesquisador não tem como recorrer à classificação atribuída pelo próprio grupo. No entanto, a teoria proposta por estes três pesquisadores, a preocupação está centrada no questionamento da consistência (métodos usados para a composição da tipologia) das classificações e tipologias, usadas correntemente pelos arqueólogos.

As tipologias são utilizadas como meio de comunicação entre os arqueólogos, alguns tipos foram estabelecidos ao longo da história da arqueologia, e mesmo com o surgimento de novos métodos, técnicas e outras linhas teóricas, a consistência dos antigos tipos muitas vezes não é questionada. A classificação está sujeita a vários erros, que podem ser metodológicos (amostra, definição dos atributos, procedimentos de campo etc...) ou relacionados com a subjetividade do pesquisador (preconceito, orientação metodológica, falta de treino, experiências anteriores). Na verdade, a definição dos atributos a serem usados, bem como da tipologia, estão relacionados de acordo com o problema a ser resolvido.

A qualidade da tipologia está na habilidade do pesquisador em descrever e comunicar por meio do esclarecimento em relação à metodologia e outros critérios de definição dos tipos, tornando o trabalho dialogável com a pesquisa de outros materiais; a idéia implícita é a de que os critérios utilizados sejam mais objetivos e menos arbitrários e que os erros sejam minimizados por meio de uma metodologia mais rigorosa.

Um dos autores que questiona e se posiciona em relação ao modo de classificar é Dunell(1986); ele afirma que a classificação será sempre influenciada pela base teórica utilizada,ou seja, não existe uma classificação ateórica. Os tipos são o produto de uma visão materialista de variabilidade e representam o resultado da escolha dos atributos no momento 
da classificação; nesse modelo existem dois tipos de unidades de classificação, que se referem ao uso dos atributos: as unidades empíricas (classificação dos grupos) e as unidades teóricas e que sustentam o significados da classificação (relacionadas às classes).

Para este autor, o tipo tem definição e a classe possui descrição. As duas bases teóricas que fundamentam o modo de classificar norte-americano é o essencialismo e o materialismo histórico.

Dentre as formas de classificação, surgem algumas escolas de pensamento sobre o estilo tecnológico como critério classificatório para definição de tipologias, considerando o estilo como parte da variabilidade formal presente na cultura material e que é culturalmente significante.

\subsubsection{Estilo tecnológico}

Existe uma ampla discussão acadêmica sobre a definição de estilo, onde este reside na variabilidade formal e o que este comunica, questionando sobre a dissociação do estilo da funcionalidade, culminando na possibilidade ou não em se formar uma teoria geral sobre o estilo.

Quanto às definições de estilo, há um consenso dos autores sobre três características gerais intrínsecas a este conceito(Hegmon, 1992):

1) que o estilo refere-se a determinado modo de fazer algo ou alguma coisa;

2) que este modo de fazer implica em escolhas dentre possibilidades alternativas;

3) que é próprio de um determinado tempo e lugar.

Sackett(1977) por outro lado, afirma que quando referido no âmbito da arqueologia, o estilo é o complemento perfeito da função, pois é impossível mencionar um conceito sem remeter-se ao outro pelo fato de que ambos compartilham a responsabilidade de explicar a natureza da variabilidade formal nos artefatos, ou seja, sobre a dimensão formal do registro arqueológico, mas que seria um equívoco crer que estilo e função esgotariam todo o potencial da variabilidade formal.

Para este autor, o artefato poderia ser visto de duas formas, sob o aspecto funcional, que remete à ação, como o objeto foi manufaturado e usado numa sucessão de atividades que compunham a vida social de determinado grupo. Neste caso, a preocupação está ligada ao papel do artefato, o modo como ele se comporta como parte integral de um sistema 
cultural. Dessa forma, a função não é somente definida de acordo com seu papel pragmático como tecnologia e economia, mas simultaneamente como uma cultura material que é participante ativo no âmbito social e ideológico, pois até os objetos utilitários mais banais podem contribuir para a construção de redes de interação social e possuir determinada carga ideológica. A função é classificada como voz ativa no modelo de Sackett.

A segunda forma em que o objeto pode ser visto é sob o aspecto estilístico. Sob este aspecto, o autor conclui que o artefato é analisado em termos de valor diagnóstico para especificar um contexto particular histórico-cultural e que este objeto em sua forma e design é improvável que ocorra em outros locais.

A forma seria um indicador histórico da expressão específica da cultura material de uma sociedade, pois esta explora apenas um estreito leque de opções de confecção de determinado objeto dentro de um enorme espectro de possibilidades formais que são potencialmente utilizáveis, pois existem muitas maneiras de se alcançar o mesmo fim e a sociedade tende a escolher uma delas. Considerando que o número de possibilidades equivalentes de se alcançar o mesmo fim é tão grande que a chance de que uma escolha feita em uma sociedade seja feita por outra não relacionada é quase impossível.

Para Sackett(1991), o estilo reside nas escolhas feitas pelos artesãos, justamente porque caracterizam este modo específico de fazer de determinado tempo e espaço. Sackett denomina cada escolha que é feita de variação isocréstica. Isocréstico quer dizer "equivalente em uso" e para Sacket o estilo é isocréstico; as escolhas são socialmente transmitidas e o grau de similaridade entre estas escolhas feitas em locais historicamente ligados depende da intensidade da interação social compartilhada pelos seus membros. A semelhança estilística indicaria uma aproximação intensa. Se estas comunidades não estiverem relacionadas, então houve algum tipo de transmissão cultural.

Sackett divide os artefatos em utilitários (fins tecnológicos e econômicos) e não utilitários (a função primária está relacionada aos aspectos sociais e ideológicos); no entanto concebe que todo artefato apresenta aspectos estilísticos e funcionais, pois mesmo um objeto utilitário feito para uma função estritamente pragmática, está comunicando aos membros do grupo para que ele serve, que tipo de pessoa utiliza e em quais situações sociais deve ser usado. A limitação é que Sackett esquece de pontuar que num mesmo grupo pode haver variação de determinado artefato, de mesmo uso, mas de forma diferente.

De acordo com Binford (1980),os artefatos possuem função primária(utilitária e não utilitária) e secundária(estilística); dentre as categorias de função primária, estão as classes 
tecno-econômicas, sócio-técnicas e ideo-técnicas, que para este autor são as funções principais do artefato e os atributos que ele define como estilísticos possuem um papel secundário na composição, uso e comunicação, ou seja, na variabilidade do artefato.

Weissner(1991) em seus estudos sobre estilo, conclui que os significados do mesmo estão relacionados com a identidade étnica, social e individual. Afirma que todos os estudos discordam onde reside o estilo, mas todos concordam que o estilo está relacionado com a comunicação. A função dos objetos também comunica sobre o estilo de vida.

Para Weissner a dicotomia entre função e estilo é impossível, pois considera que é uma situação ilusória pensar que é possível separar os atributos estilísticos dos funcionais; o estilo é desta forma, parte do comportamento não-verbal e possui vários sinais comunicativos que derivam de suas partes funcionais; desta forma, o estilo é usado para obter informação de interação social. Weissner também categorizou os tipos de estilo em "emblemático" e "assertivo", os quais sugeriu que o estilo comunica identidade individual e social; a identidade social é importante para os indivíduos para que estes sejam capazes de criar uma auto-imagem através da comparação social e projetar essa imagem de uma forma positiva. O estilo emblemático seria a variação formal no objeto que comunica a marca cultural de determinada população e o estilo emblemático comunica identidades pessoais, que é mais difícil de reconhecer, como, por exemplo, marcas de poder e de distâncias sociais. A partir de seus estudos com as pontas de projétil, a autora levanta algumas questões sobre a escolha dos atributos durante a análise: como definir quais itens e as variáveis dos mesmos carregam informação social; quais condições embasam o uso de certos itens da cultura material que transmitem mensagem sobre as relações sociais e quais as diferenças de padrões da variação estilística sobre o espaço correspondem a relações intra e extra-grupos. A autora no que concerne aos atributos, conclui que o estudo dos atributos isolados não dá conta de explicar o que caracteriza uma ponta, mas sim o conjunto de atributos.

Peter Roe (1995), acerca da dicotomia entre estilo e função, argumenta que as evidencias etnográficas mostram que o estilo a decoração não pode ser dissociada da função, pois ela faz parte da totalidade do artefato; essa afirmação é baseada no fato de que diversas sociedades não possuem o conceito de "belo", ou de "arte", mas sim os conceitos "correto" e "real". Isso significa que a decoração na verdade carrega a marca de uma execução técnica correta para os padrões êmicos. Os estudos de Washburn sobre a simetria e o conceito étnico de estilo reforçam as argumentações de Roe(1995); Washburn( 
desenvolveu um programa para reproduzir a iconografia de determinado grupo em computador com o intuito de identificar os padrões de "estética" êmicos; como resposta, alguns padrões foram identificados como o "jeito certo de se fazer", e outros padrões como aceitáveis para vender ou pra trocar com outros grupos,

Jordan e Shennan(2003) centram sua preocupação na língua, pois esta é fundamental na transmissão dos preceitos(atributos), havendo interação social horizontal( difusão de determinada característica social ) e vertical( apreensão de conhecimentos de uma geração para outra). Estes autores acreditam que uns atributos se propagam mais facilmente que outros, a forma persiste mais do que o significado.

Carr(1995) apontou a noção de estilos múltiplos, ou seja, a idéia de que o artefato comunica diversos tipos de informações e que diferente atributos podem estar relacionados a diferentes estilos,e que há a necessidade em tentar definir atributos que possam ser indicadores mais regionais de uso; também pode-se estabelecer uma hieraquia de atributos que defina determinado conjunto ou a comparação dos atributos também pode ser feita pela diferença, observando os atributos de determinada tradição e relatando os que estão ausentes no material.

Esta corrente, como algumas outras, define que o estilo reside nos atributos; é proposta uma descrição dos atributos que caracterizam determinados conjuntos de artefatos, num tempo e espaço.

Há uma outra corrente neo- evolucionista, representada pelos textos do Dunell(1978) e O'brien(2001), que organiza a interface com a ecologia cultural.

Estes autores propõem que os atributos podem ser classificados em atributos funcionais e atributos estilísticos; os funcionais estariam relacionados com o favorecimento da capacidade de evolução de um artefato, melhorando as condições adaptativas ao meio ambiente ; os atributos estilísticos são aqueles que são secundários e que não afetam a performance do artefatos.

Para Dunell (1978), os atributos que possuem maior resistência temporal são os funcionais, pois perduram por várias gerações. Essa resistência temporal caracteriza a funcionalidade. Já os atributos estilísticos, como não tem influência no fitness, ou seja, no valor adaptativo do objeto, para este autor os atributos estilísticos são caracterizados por não terem persistência temporal e por comunicarem significados ideológicos que serviriam para definir cronologia espacial e interação pessoal. A inovação na confecção de certos artefatos, mesmo possuindo características funcionais, pode não ser aceita pelo grupo, incluso por 
fatores pessoais; neste caso os atributos, mesmo com características de valor adaptativo se tornariam estilísticos, pois não possuem resistência temporal.

Na corrente neo-evolucionista, o estilo na verdade não tem função, mas no processo adaptativo tem um propósito(Purpose); a adaptabilidade está relacionada com a função e o estilo implica no modo como se dá essa adaptabilidade; a adaptação é a resposta imediata ao que o ambiente oferece.

Nesta teoria biológica, existem criações semelhantes são chamados de análogas, ou seja, um conjunto e formas existentes em locais diferentes que tem a mesma finalidade funcional-como, por exemplo, a invenção independente da cerâmica; nesta teoria, há um pressuposto estruturalista, no sentido de que algumas formas adaptativas são universais.

Existem também as semelhanças que são homólogas, ou seja, um conjunto de formas não funcionais (no sentido pragmático) existentes em locais diferentes que não teriam como ser inventadas paralelamente, pressupondo algum tipo de contato. Estas semelhanças estas relacionadas ao estilo e visam entender maior ou menor interação entre os grupos.

\section{2 Referencial metodológico:}

Critérios analíticos

Este item contém os critérios de análise tecnológica de cultura material lítica e cerâmica, centrada nos seguintes autores:

- Lítico: Leroi-Gourhan (1964/65,1971), Brézillon (1969), Tixier(1980), LammingEmperaire (1967), Pallestrini-Chiara (1978), Morais (1980/83), VilhenaVialou(1980);

- Cerâmica : Shepard (1963), Seronie-Vivien (1975), Rice (1982), Rye (1981), Mirambell \& Lorenzo (1983), Cremonte (1991), Alves (1982, 1988, 1994,1997), Alves \& Girardi (1989), Goulart (2004).

Os critérios analíticos centram-se em torno das seguintes classificações:

- Lítico:peças preparatórias (bloco, lasca de descorticamento, núcleo, percutor); peças de natureza acidental(lasca sem retoque, lamela, lâmina, resíduos, fragmentos); peças utilizadas (lascas utilizadas); artefatos (biface, buril, chopping-tool, cunha, faca, furador, instrumento duplo, lâmina de machado lascada, lasca com trabalho secundário, lasca retocada, picão, plaina, ponta, raspador, uniface); 
(Morais,1983:46)

- Cerâmica:argila, queima, cerâmica, base, boca, pescoço, bojo, borda, engobo, pintura (monocromática/policromática), decoração plástica, técnicas de montagem e acabamento de superfície, tempero/ antiplástico(Alves 1982/88), pasta, índice de temperatura de queima, resistência mecânica da cerâmica , minerais corantes, (Alves 1994/97, Goulart 2004).

Ficha de análise -Indústria lítica

A indústria lítica foi analisada baseada na ficha tecnotipológica desenvolvida por Morais(1987). O procedimento consistiu na separação das peças líticas por tipo de matériaprima; foram então separadas as matrizes, e em seguida os produtos da debitagem e de retoque e os resíduos.

Após a triagem, as peças que não foram utilizadas são separadas da peças com marcas de uso (polimento, desgastes e serrilhamento); as peças com retoque e os artefatos passíveis de classificação tipológica. 


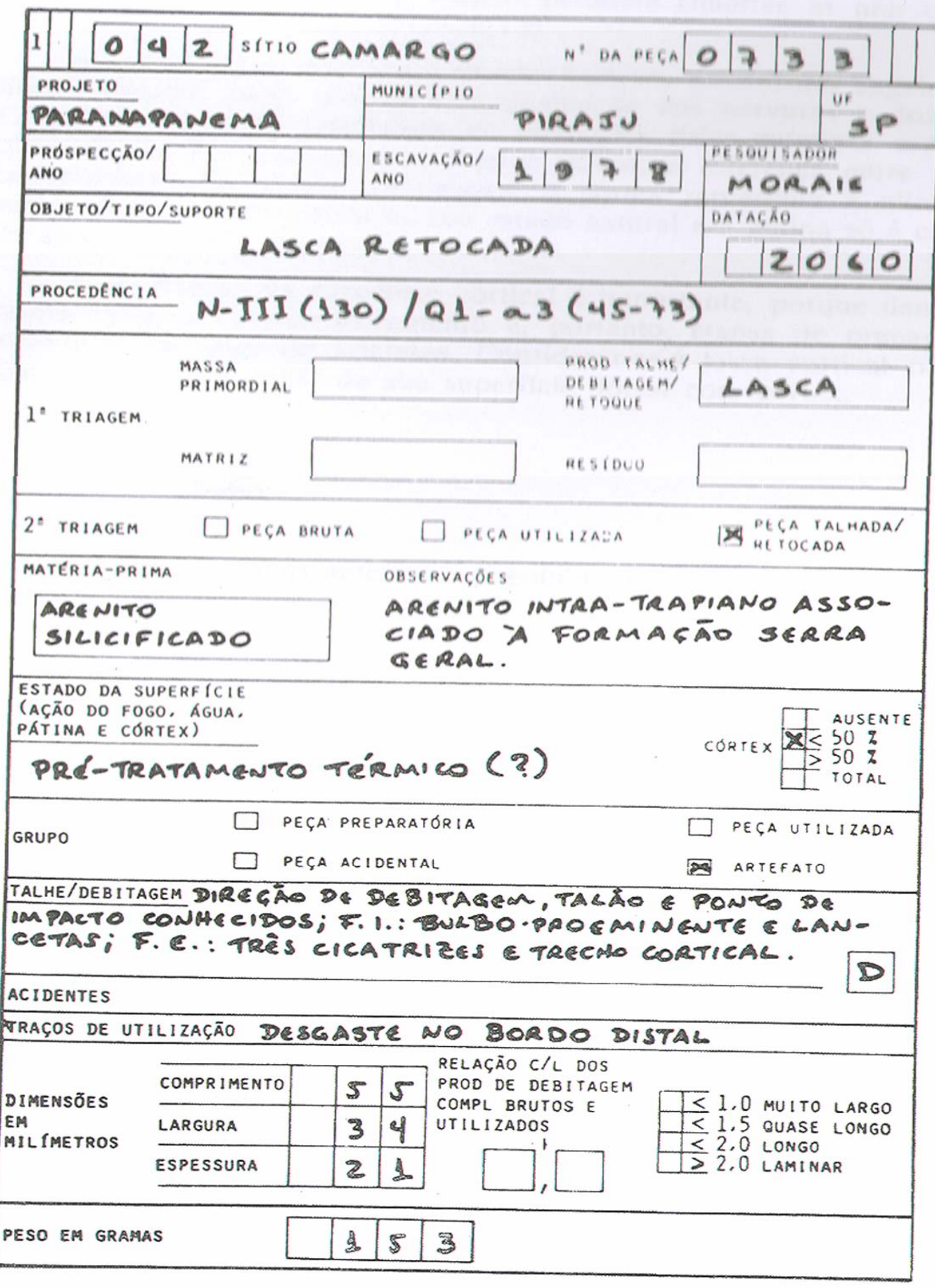

Fonte:Morais,1987 


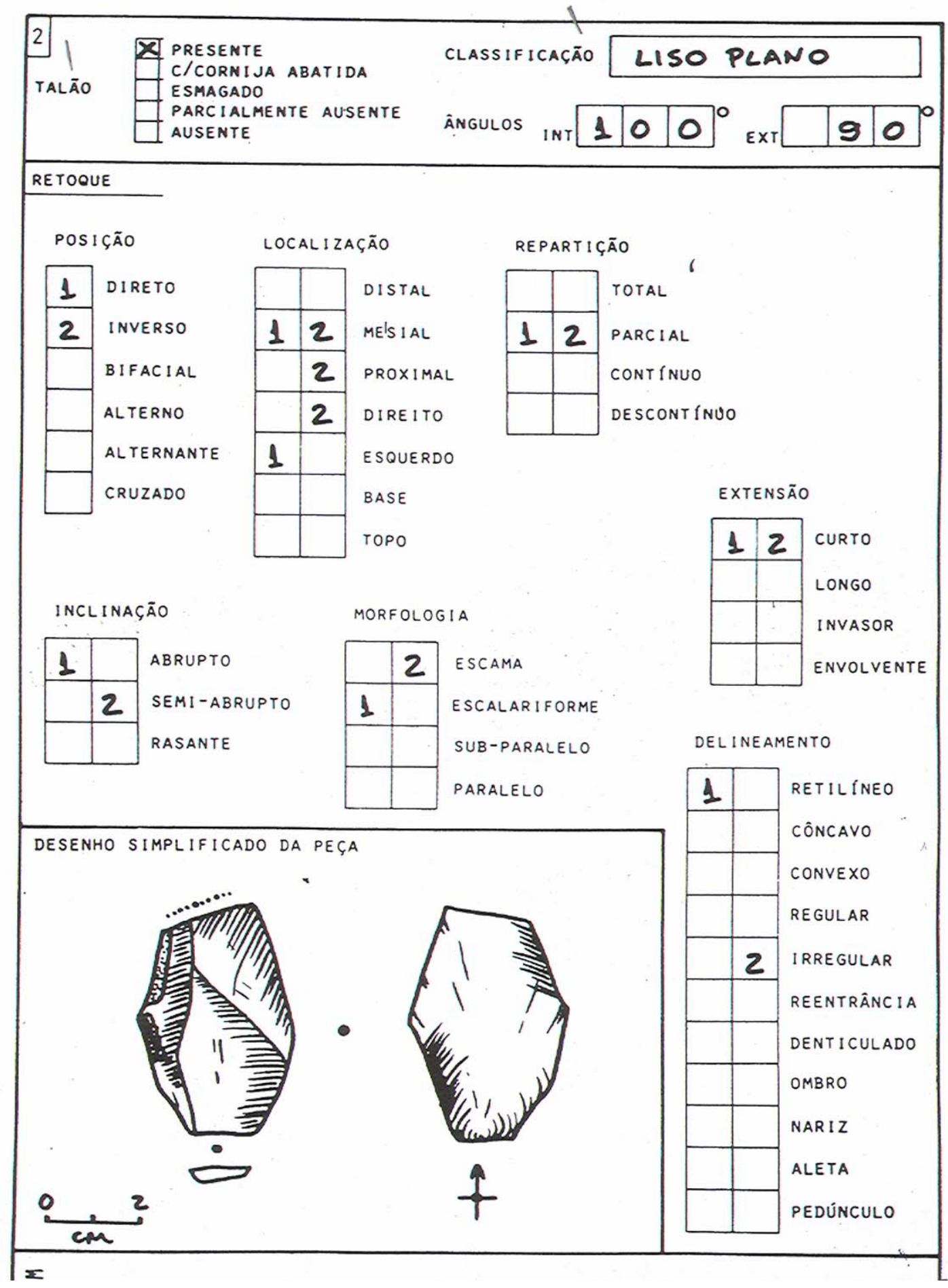

Fonte: Morais,1987 
Ficha de análise-indústria cerâmica

A ficha utilizada para a análise dos fragmentos cerâmicos é a de Alves(1988); a ficha está dividida em duas partes. A primeira parte está relacionada com a tipologia e a segunda com a análise técnica(arqueometria). Na primeira parte, procedimento de análise consiste primeiramente na classificação dos elementos cerâmicos de acordo com o tratamento de superfície(interna e externa):

- com pintura, engobo, banho;

- decoração plástica;

- lisos(ausência de pintura ou decoração plástica).

$\mathrm{Na}$ primeira parte da ficha( relacionada à tipologia) é reservada para a classificação de vasilhames inteiros ou parcialmente reconstituídos; numa segunda instancia são classificados elementos cerâmicos fragmentados com indicações morfológicas(borda, base, bojo, lábio, pescoço, parede).Os itens de avaliação: forma, diâmetro, ângulo, técnica de montagem, tratamento de superfície (alisamento, polimento, pintura, decoração plástica), brunidura, reconstituições e função (emprego social dos artefatos).

Na segunda parte da ficha de Goulart (2002), a análise técnica consiste na confecção de lâminas microscópicas para a análise da pasta cerâmica(composição mineralógica, porcentagem de grãos, adição de chamota e outros antiplásticos, seleção de grãos de quartzo); os difratogramas de raio-X são realizados para definir os níveis de temperatura de queima, detecção dos compostos cerâmicos, resistência mecânica dos vasilhames, queima(oxidante/redutora), análise química das superfícies pintadas e análise microestrutural.

A análise técnica é processada por técnicas arqueométricas em quatro universos científicos:

- microscopia de luz transmitida:

- difratometria de raios-X

- espectometria de raios- $X$

- microscopia eletrônica de varredura

- microanálise química 
Para a realização dessas técnicas são selecionadas amostras de cerâmicas contextualizadas do sítio Menezes.

O penúltimo item desta parte da ficha é representado por um desenho da peça com croquis das microestruturas observadas. Por último, é feita a interpretação dos dados analíticos (fonte de matéria-prima, adição ou não de antiplástico etc.. ).

\section{Ficha tecnotipológica para análise cerâmica - ALVES (1988)}

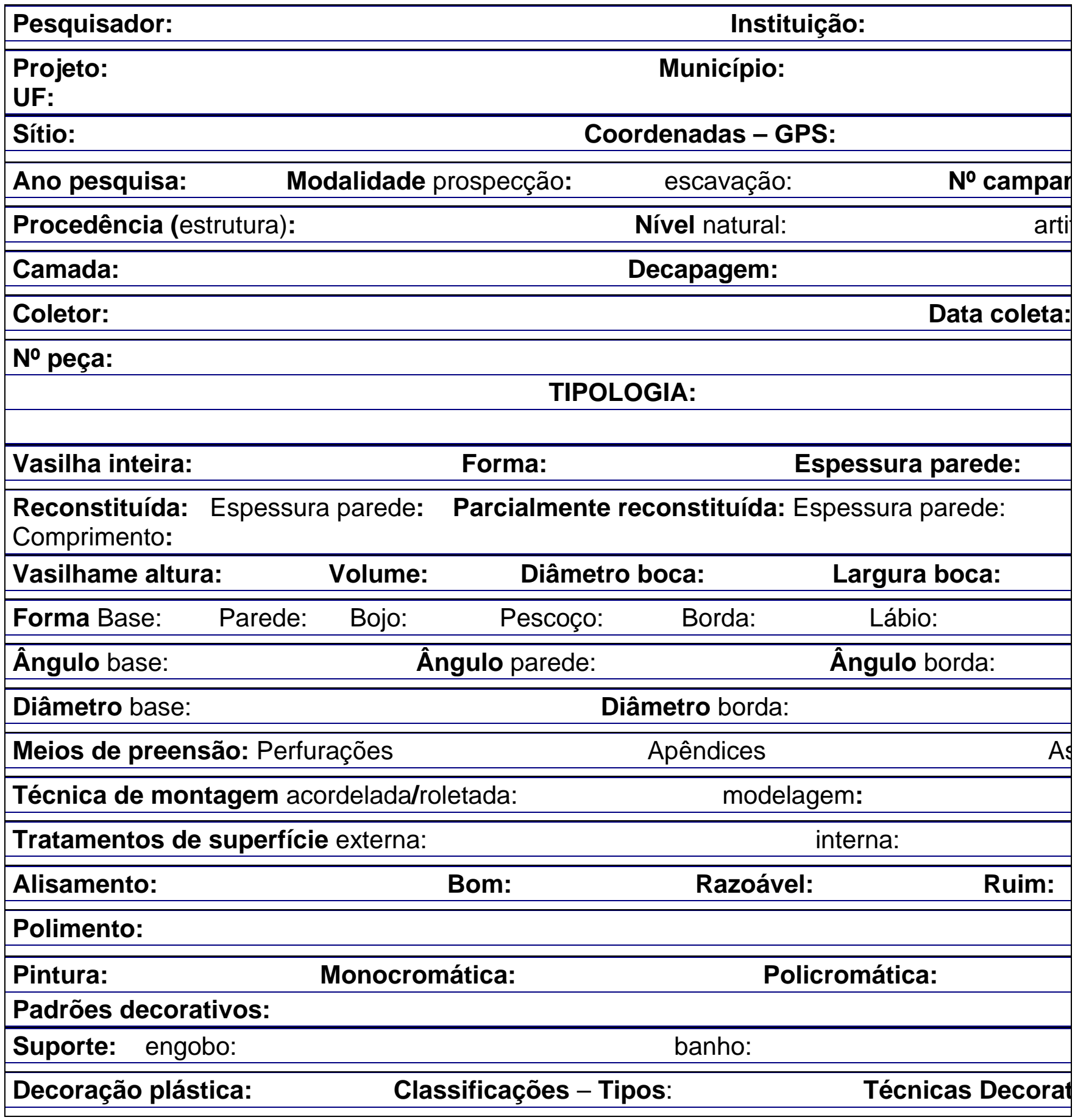




\begin{tabular}{|l|}
\hline Incisões - tipo (s): \\
\hline Pressões - tipo (s): \\
\hline Pressões - Incisões - tipo(s): \\
\hline Relevos - tipo (s): \\
\hline Aplicações: \\
\hline Decoração plástica e pintura: \\
\hline Padrões decorativos: \\
\hline Pintura e polimento: \\
\hline Brunidura: \\
\hline Reconstituição (ábaco e softwares): \\
\hline Emprego social dos artefatos (Funções): \\
\hline Desenho e foto da peça: \\
\hline
\end{tabular}

\section{ANÁLISE TÉCNICA - ALVES (1988) e GOULART (2004)}

$\mathrm{N}^{\circ}$ PEÇA :

PASTA: Microscopia de luz transmitida: lâminas microscópicas (seções delgadas)

- No lâmina:

- Procedência da amostra:

- Textura e estrutura:

- Granulação:

- Composição mineralógica e porcentagem grãos:

\begin{tabular}{|c|}
\hline$<10 \mu \mathrm{m} \quad$ (silte fino) \\
\hline $10-20 \mu \mathrm{m}$ (silte médio) \\
\hline $20-60 \mu \mathrm{m}$ (silte grosso) \\
\hline$>60 \mu \mathrm{m} \quad$ (areia) \\
\hline
\end{tabular}

- Descrição dos minerais e relações texturais:

Ocorrência chamota:

fragmentos fosfáticos:

Outros:

- Fonte(s) de matéria-prima argilosa: 
- Adição de antiplásticos:

- Seleção de grãos de quartzo:

QUEIMA: Difratometria de raios-X (estrutura cristalina) - difratogramas:

- No difratogramas:

- Procedência amostras: - superfície externa: - superfície interna:

massa:

- Picos difratogramas e minerais correspondentes:

-Inferência da temperatura de queima:

- Detecção de compostos corantes:

- Resistência mecânica do vasilhame cerâmico (inferida pela temperatura de queima):

- Queima: Oxidante?/Redutora?

- Processo(s) queima: fogueira (s) rasa (s): $\quad$ forno (s): $\quad$ fossa (s):

PASTA/PINTURA: Espectrometria de raios-X ( análise química da pasta e/ou da superfìcie pintada) :

- Elementos químicos maiores detectados

- Elementos químicos potencialmente cromatóforos (p. ex. Fe, Ti, Mn, etc)

PINTURA/PASTA: Microscopia eletrônica de varredura ( análise microestrutural) e microanálise química

- Procedência/amostras:- Superfícies externa: interna:

massa:

- No das fotomicrografias: 


\begin{tabular}{|l|}
\hline - Microestruturas observadas (poros, fissuras, orientação das partículas na massa): \\
\hline \\
\hline \\
\hline - Elementos químicos potencialmente cromatóforos (p. ex. Fe, Ti, Mn, etc) \\
\hline \\
\hline - Desenho da peça com croquis das microestruturas observadas \\
\hline \\
\hline \\
\hline \\
\hline \\
\hline \\
\hline INTERPREÇÃO DOS DADOS ANALÍTICOS: considerar na interpretação os dados relativos a: \\
\hline - Fonte provável da matéria-prima \\
\hline - Adição provável ou não de antiplásticos (quais dados corroboram uma ou outra inferência?) \\
\hline - Temperatura de queima ultrapassou ou não os $500^{\circ} \mathrm{C} ?$ \\
\hline - Queima foi redutora ou oxidante? Esta condição foi homogênea para a amostra ou há variação \\
das superficies para a parte central da peça (massa)? \\
\hline - Puderam ser detectados materiais corantes nas superfícies da peça? \\
\hline \\
\hline \\
\hline
\end{tabular}




\subsection{Metodologia das pesquisas de campo}

A metodologia empregada nas escavações é a do método etnográfico de "Superfícies Amplas", de Leroi-Gourhan(1972), do Collège de France, adaptado ao solo tropical brasileiro por Pallestrini(1975); este método emprega procedimentos técnicos de ataques verticais para indicar as áreas arqueológicas férteis, e nestas são aplicados os ataques horizontais que consistem na execução de decapagem por níveis naturais(Alves 1992).

O pressuposto teórico deste método é o conceito de totalidade social (fato social total) de Mauss (1974), que concebe a tecnologia como produto dos sistemas sociológico/psicológico, fisiológico e simbólico; estes conceitos foram traduzidos em procedimentos técnicos supracitados e que consistem nas seguintes técnicas tridimensionais: ataques verticais (perfil estratigráfico), trincheiras e ataques horizontais compostos por decapagens.

A decapagem por camadas naturais evidencia os contextos arqueológicos, que podem ser considerados como cenas congeladas do cotidiano de populações pré-históricas (e précoloniais), demonstrando a relação estabelecida entre os vestígios; este método visa a coleta sistemática dos vestígios, com registro visual detalhado, que consiste na produção de desenhos, fotos, pranchas, mapas, diário de campo e medidas de altura, profundidade, extensão e distâncias medidas por GPS. 


\section{Capítulo 2: Ambientação e escavação do sítio Silva Serrote e do sítio Menezes e as Pesquisas de campo.}

\subsubsection{Ambientação do sítio Silva Serrote:}

O sítio Silva Serrote localiza-se vale do Alto Paranaíba, MG. Situa-se a $18^{\circ} 48^{\prime} 05^{\prime \prime}$ de latitude sul e a $46^{\circ} 45^{\prime}$ '05" de longitude Greenwich, aproximadamente a 963 m, no município de Guimarânia-MG, a 18 $52^{\prime}$ '00" de latitude sul e a 460 46' 19" de longitude Greenich. Localiza-se na Fazenda "Serrote", de propriedade do Sr. Delvo Silva. Guimarânia faz parte da unidade federativa de Minas Gerais, mesorregião do Triangulo Mineiro/Alto Paranaíba e microrregião de Patos de Minas. A microrregião de Patos de Minas é formada pelas cidades de Patos de Minas, Guimarânia, Lagoa Formosa, Carmo do Paranaíba, Tiros, Arapuá, Rio Paranaíba, Matutina, São Gotardo e Santa Rosa da Serra (veja o quadro).Municípios vizinhos a cidade de Guimarânia: Ao Sul - Cruzeiro da Fortaleza; a Oeste - Patrocínio; ao Norte - Coromandel; a Leste - Patos de Minas.

O Município de Guimarânia possui uma área territorial de 371 Km2. Possui sua altitude máxima de $1.258 \mathrm{~m}$ no Morro das Pedras e altitude mínima de $830 \mathrm{~m}$ na foz do Rio Santana. A altitude no ponto central da cidade é de $915 \mathrm{~m}$

O clima vigente é tropical, subquente e semi-úmido, apresentando uma estação seca de duração de 4 a 5 meses, com média anual de pluviosidade atinge 1400mm. A média anual de temperatura é de $20^{\circ} \mathrm{C}$, com mínimas de $18^{\circ} \mathrm{C}$ e máximas de $22^{\circ} \mathrm{C}$.

A vegetação original é de cerrado, consideravelmente desmatado e que conserva uma mata de galeria nas margens dos rios.

O município de Guimarânia localiza-se no nordeste do triângulo mineiro, nos chapadões do vale do Alto Paranaíba e de seus afluentes; é uma área de transição de terrenos e onde pode-se verificar formações pré-cambrianas(antigas) e formações mais recentes(IBGE,1970:in Alves, 1988).

O sítio Silva Serrote apresenta três divisões topomorfológicas: a serra dos Óculos, cuja forma do topo é em crista e compõe uma área mais alta e dissecada; os topos planos, (achatados) e que descem em rampas em direção aos rios; e as várzeas do Rio Espírito Santo. O sítio situa-se no segundo compartimento, no topo de um interfluvio entre os córregos Bebedouro e Pontezinha(Alves, 1988). 
Quanto ao tipo de solo, o sítio é composto pelo latossolo vermelho; o município de Guimarânia pertence geologicamente ao Proterozóico Superior e a litoestratigrafia associada ao Supergrupo São Francisco, que abrange o grupo Bambuí, representado na região formações Paraopeba e Paranoá. São observadas rochas intrusivas, pertencentes ao grupo Iporá, do período cretáceo, que cortam a formação Paranoá. Recobrindo o conjunto, ocorre um capeamento de sedimentos terciários (Alves,1988)

Mapa 2 : Localização da cidade de Guimarânia-MG

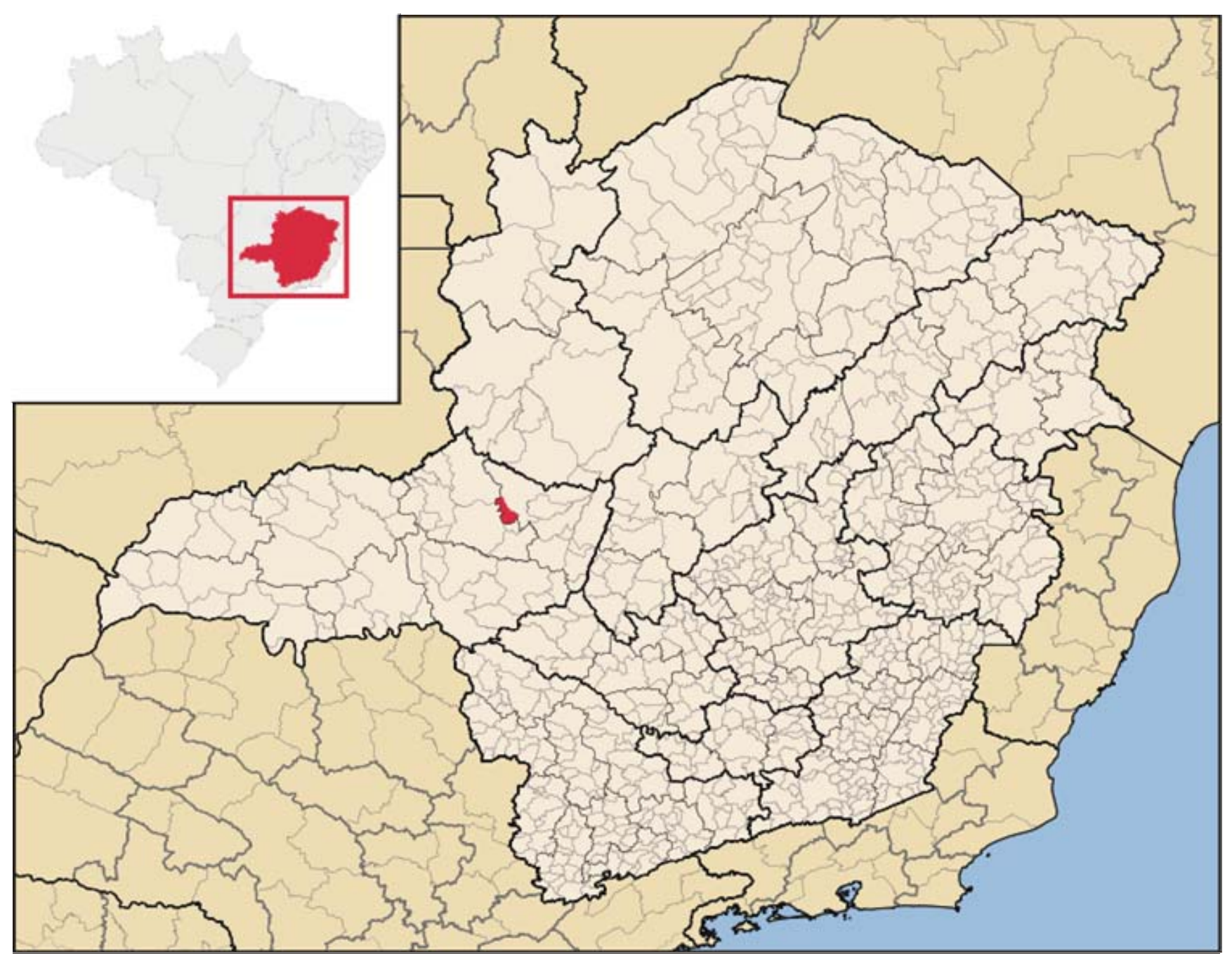

Fonte(Google Maps, 2008)

Cidade de Guimarâmia 


\subsubsection{Ambientação do Sítio Menezes}

O sítio Menezes está situado no vale do Alto do Paranaíba, no município de PerdizesMG. O município apresenta um território semi-montanhoso e uma área de $2431 \mathrm{~km}^{2}$.A sede do município está situada a 1047 m de altitude e sua localização é $19^{\circ} 21^{\prime} 00^{\prime \prime}$ de latitude e sul e $47^{\circ} 17^{\prime} 30^{\prime \prime}$ de longitude oeste.

O clima que vigora é "tropical sub-quente e semi-úmido", que apresenta duas estações bem definidas, a chuvosa e a seca. São quatro meses secos (fim de maio a começo de setembro), um mês de frio mais intenso (junho ou julho) com temperatura inferior a $18^{\circ} \mathrm{C}$. A temperatura média anual varia de $18^{\circ}$ a $22^{\circ} \mathrm{C}$. No verão, não registra máximas muito elevadas e o mês mais quente apresenta média superior a $22^{\circ} \mathrm{C}$ (IBGE, 1977).

O tipo de solo de Perdizes é latossolo vermelho escuro e a vegetação atual é secundária, formada de cerradão, cerrado e mata de galeria (IBGE, 1977).

.A vegetação é de cerrado, ambientalmente degradado, com mata galeria nas margens dos rios. A área foi reflorestada; mata galeria e várzea com campo antrópico, pastos e práticas de culturas permanentes.

Perdizes possui uma vasta superfície ondulada e atravessada pelos afluentes do rio Araguari que delimita o oeste mineiro e o triângulo. A área apresenta tr es compartimentos topomorfológicos:

- topo de planalto não dissecado, com topos e planos conservados.

- Área de dissecação escarpada, com anfiteatros e profundas dissecações, apresentando escapamentos.

- Área interfluvial e dissecada com interfluvios alongados e em rampas.

Apresenta como tipo de solo o" latossolo vermelho escuro".

O rio Quebra-anzol e o rio Galheiro são os principais rios da cidade e pertencem à bacia do rio Paranaíba. O município está situado em uma região pertencente à Bacia hidrográfica do Rio Quebra-Anzol, principal afluente da margem direita do Rio Araguari; nasce nas divisas dos municípios de Ibiá, Sacramento e Bambuí;sua bacia hidrográfica total é de $10.233 \mathrm{~km}^{2}$ (Alves,1983/84).

A formação geológica pertence ao Pré-cambriano Superior, com ocorrências de rochas alcalino-básicas do grupo Araxá, próximos às ocorrências da formação Bauru da bacia Sedimentar do Paraná.(Barbosa, 1970 apud Alves, 1982,1983/1984). 
O grupo Araxá é composto de gnaisses e xistos, com ocorrência de anfibolitos, quartzitos e corpos graníticos - é um complexo metamórfico pré-cambriano no planalto de Araxá-MG e que ocupa a Bacia do Rio Quebra-Anzol, de onde se estende para o norte até o rio Paranaíba e seguindo Goiás adentro(Barbosa et al. 1970, apud Alves, 1982,1983/84).Ao norte e a oeste de Perdizes, o grupo Araxá e o complexo granítico-gnáissico se encontram encobertos por arenitos avermelhados ou silicificados da Formação Bauru, sob os basaltos da formação da Serra Geral e aos arenitos da Formação Uberaba.

Mapa 3 : Localização de Perdizes-MG

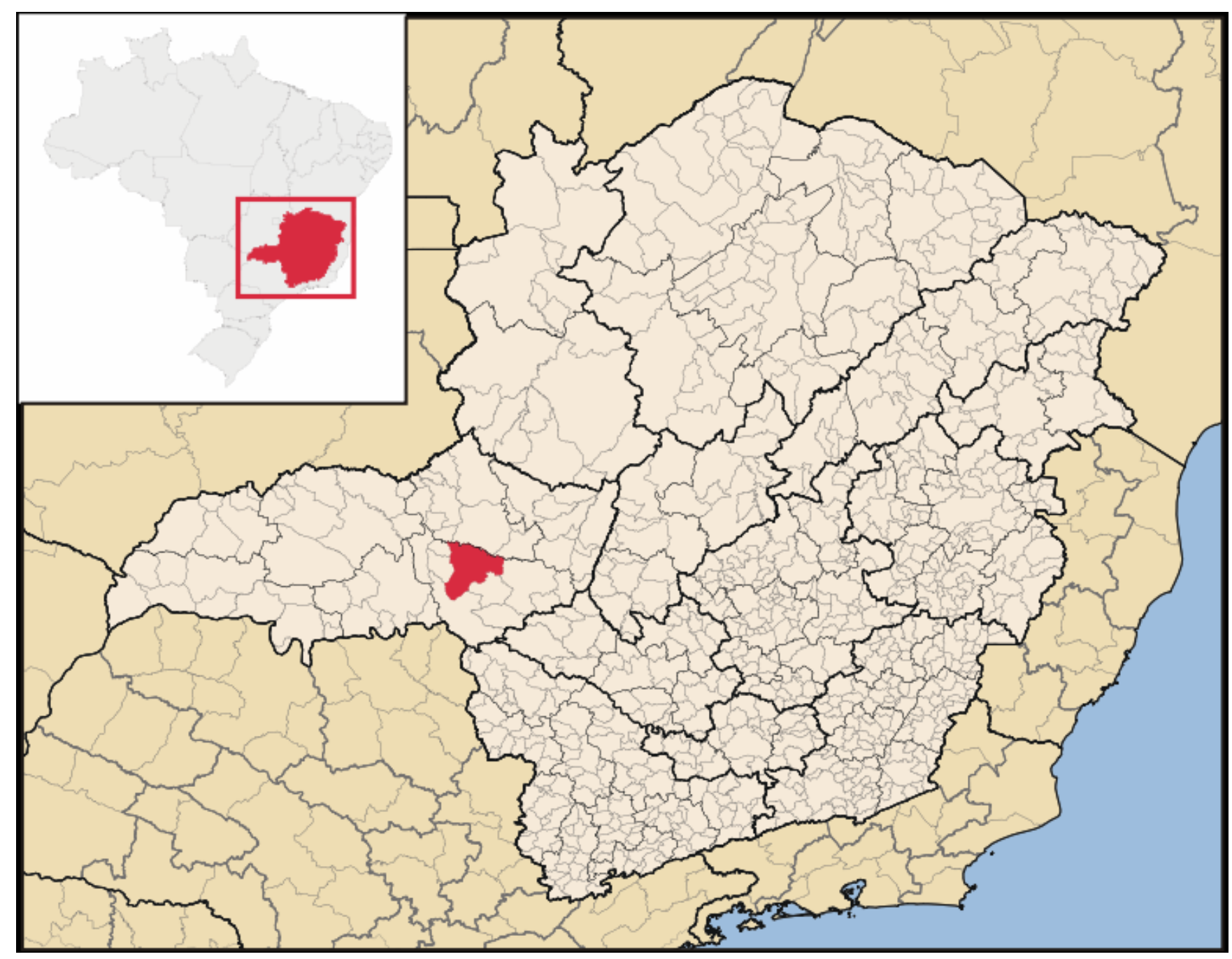

Fonte:Google Maps,2008 
Mapa 4 : Mapa Geológico do Brasil

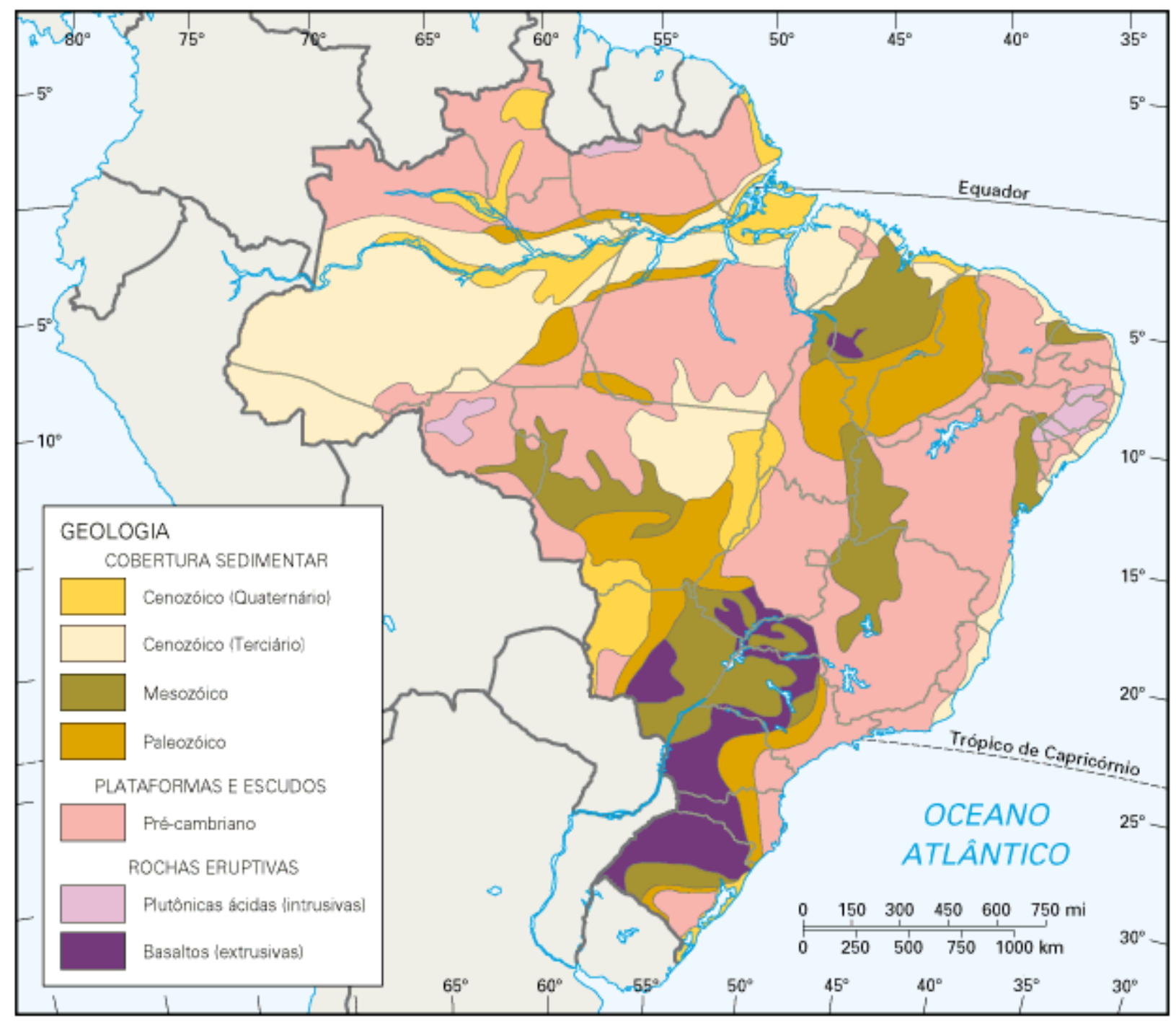

Fonte:Webcarta,2008.

Os terrenos do Vale do Paranaíba, estado de Minas Gerais encontram-se em áreas de encontro de cobertura sedimentar composta pelo Mesozóico e précambriano e rochas eruptivas Basálticas. 
Mapa 5: Vegetação - estado de Minas Gerais

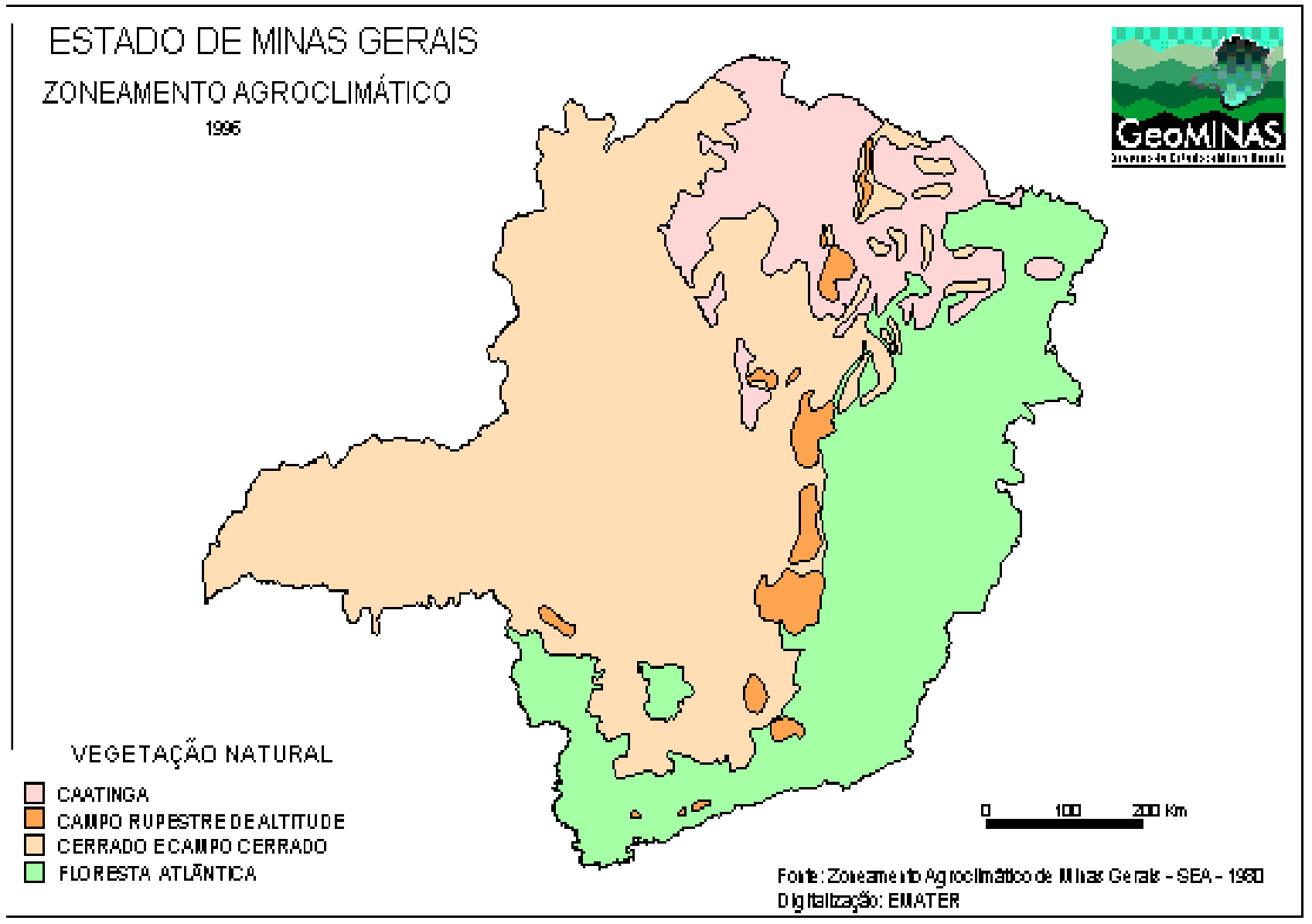

Fonte:Geominas,2008

O mapa 5 apresenta a descrição da vegetação natural do estado de Minas Gerais; A região do Projeto Quebra-anzol está inserida no bioma de cerrado e campo cerrado. 
Mapa 6 : Hidrografia - Estado de Minas Gerais

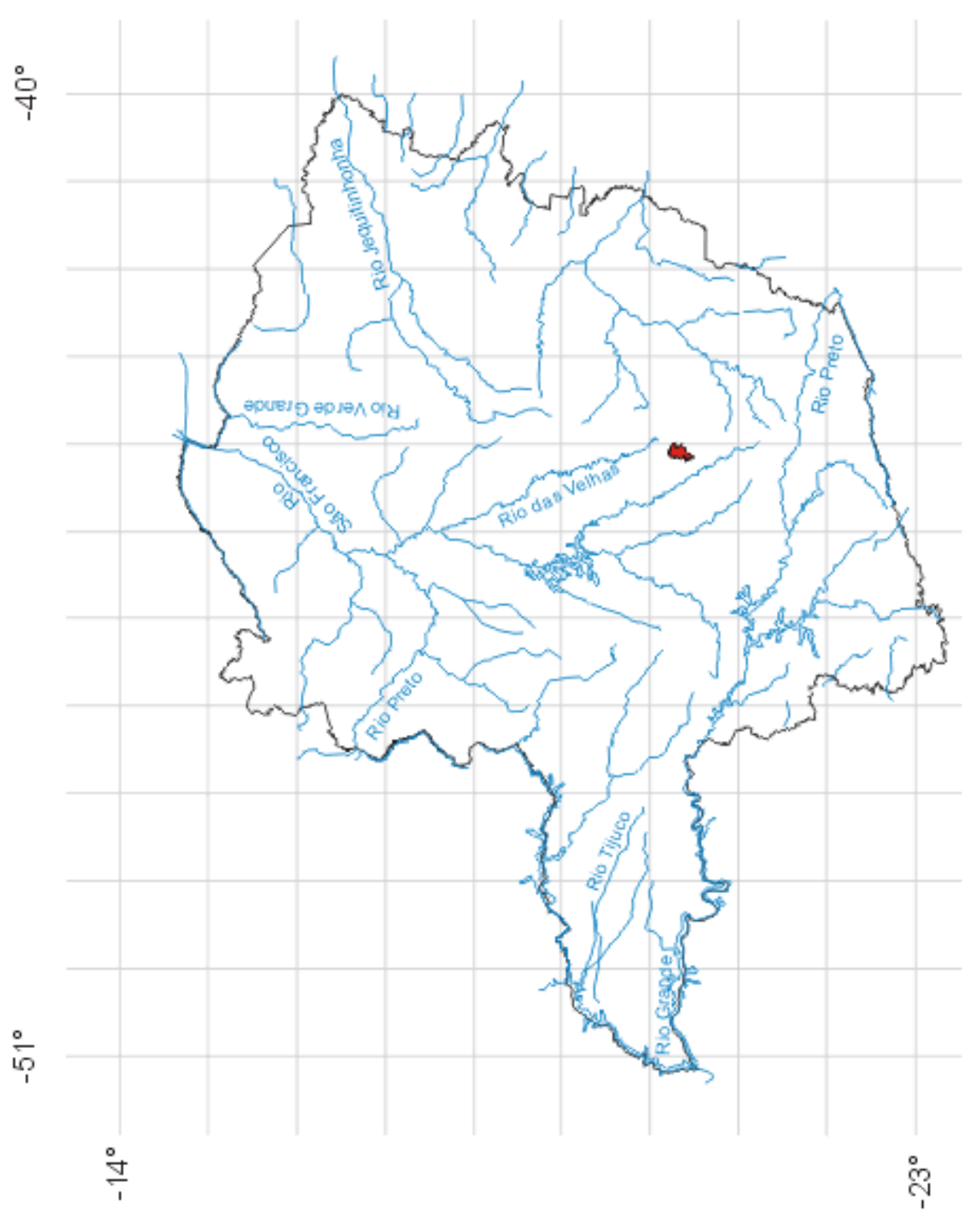

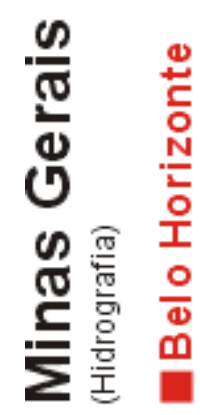

Fonte:Webcarta,2008 


\subsubsection{Pesquisa de campo no sítio Silva Serrote:}

Localizado no município de Guimarânia-MG, localiza-se na fazenda Serrote, cujo proprietário é o Sr. Delvo Silva. A escavação foi realizada de julho a agosto de 1985.

Os ataques verticais tiveram início com a escavação de um perfil estratigráfico(P1), ao lado da Mancha 1, com $12 \mathrm{~m}$ de extensão, 1,0 m de largura e 1,50 de profundidade; o nível arqueológico apresentou $40 \mathrm{~cm}$ de profundidade.

Foram abertas cinco trincheiras totalizando 83 metros de cobertura, evidenciando desta forma os acúmulos de material lítico e cerâmica na Mancha 1, escolhida desta forma para a decapagem.

A decapagem na Mancha 1 foi realizada a partir de um subquadriculamento de 8,0 X 4,0 m , executada como previamente mencionado, por níveis naturais.

A datação do sítio Silva Serrote é de $790 \pm 120$ anos A. P., datada por termoluminescência na FATEC-SP e 670 50 A. P., datado por Carbono 14 no laboratório GIF.(Alves, 2002). Seguindo a orientação metodológica, foram executados ataques verticais e horizontais.

Este sítio é de interior, aberto, com ocupação em relevo e apresenta um único nível estratigráfico, o lito-cerâmico, com até $40 \mathrm{~cm}$ de profundidade (perfil estratigráfico).

\subsubsection{Estruturas}

O conceito de estrutura, definido por Pallestrini(1972/1973) refere-se à disposição de diferentes vestígios, que se agrupam de maneira significativa no contexto arqueológico de um sítio; as estruturas podem ser subdivididas em supra-estruturas e infra-estruturas.

As pesquisas desenvolvidas no Sítio Silva Serrote revelou as seguintes estruturas:

\section{Estruturas de Habitação}

Em uma superfície de $5000 \mathrm{~m}^{2}$ (100 X 50), demarcada de 10 em 10m. Foram evidenciadas trinta manchas escuras, de forma ovalada, correspondente à aldeia; cinco trincheiras foram executadas(Mapa 5).

\section{Estruturas de Combustão}

Neste sítio encontrou-se uma fogueira circular interna à mancha 1 e apresentava carvão, cerâmica e lítico no seu interior; Foi evidenciado um sepultamento primário, em 
posição fetal, depositado em uma urna de cerâmica lisa com tampa, com tigela, localizado fora dos espaços habitacionais, mas na área do assentamento(Alves,1992).

Estruturas funerárias

Foi evidenciado sepultamento primário em posição fetal , despositado em cerâmica lisa com tampa, fora do espaço habitacional, contudo na área da aldeia.

\section{Estruturas de Lascamento}

No perfil 1 foi evidenciada uma área de lascamento; Nesta área foram evidenciados lascas, núcleos e resíduos de lascamento na mancha 1(Alves,1992).

\section{Estruturas de Concentração de cerâmica}

$\mathrm{Na}$ mancha 1, além de dois potes, um deles circundado por carvão vegetal que possibilitou a datação deste sítio por C14. Dois fusos perfurados de dimensões diferenciadas também foram encontrados nas manchas escuras e nos espaços de circulação. (Alves,1992). 
Mapa 7: Sítio Silva Serrote-Guimarânia-MG- Situação geral do sítio

SítIO SILVA SERROTE - MUNICÍPIO dE GUIMARÂNIA - MG

SITUAÇĀo GERAL DO SITIOO

SERRA DOS ÓCULOS
MAPA 4

M

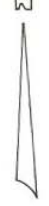

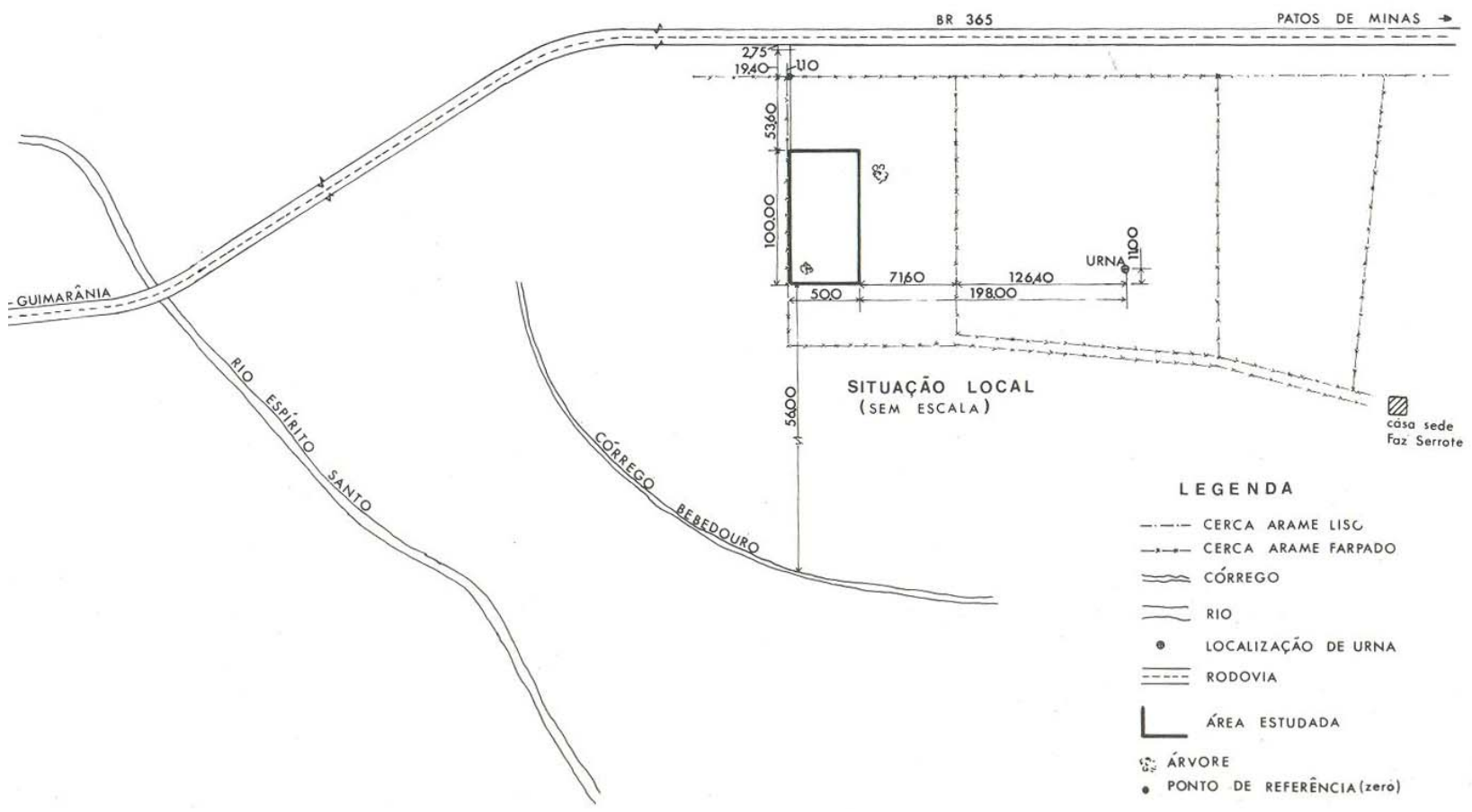




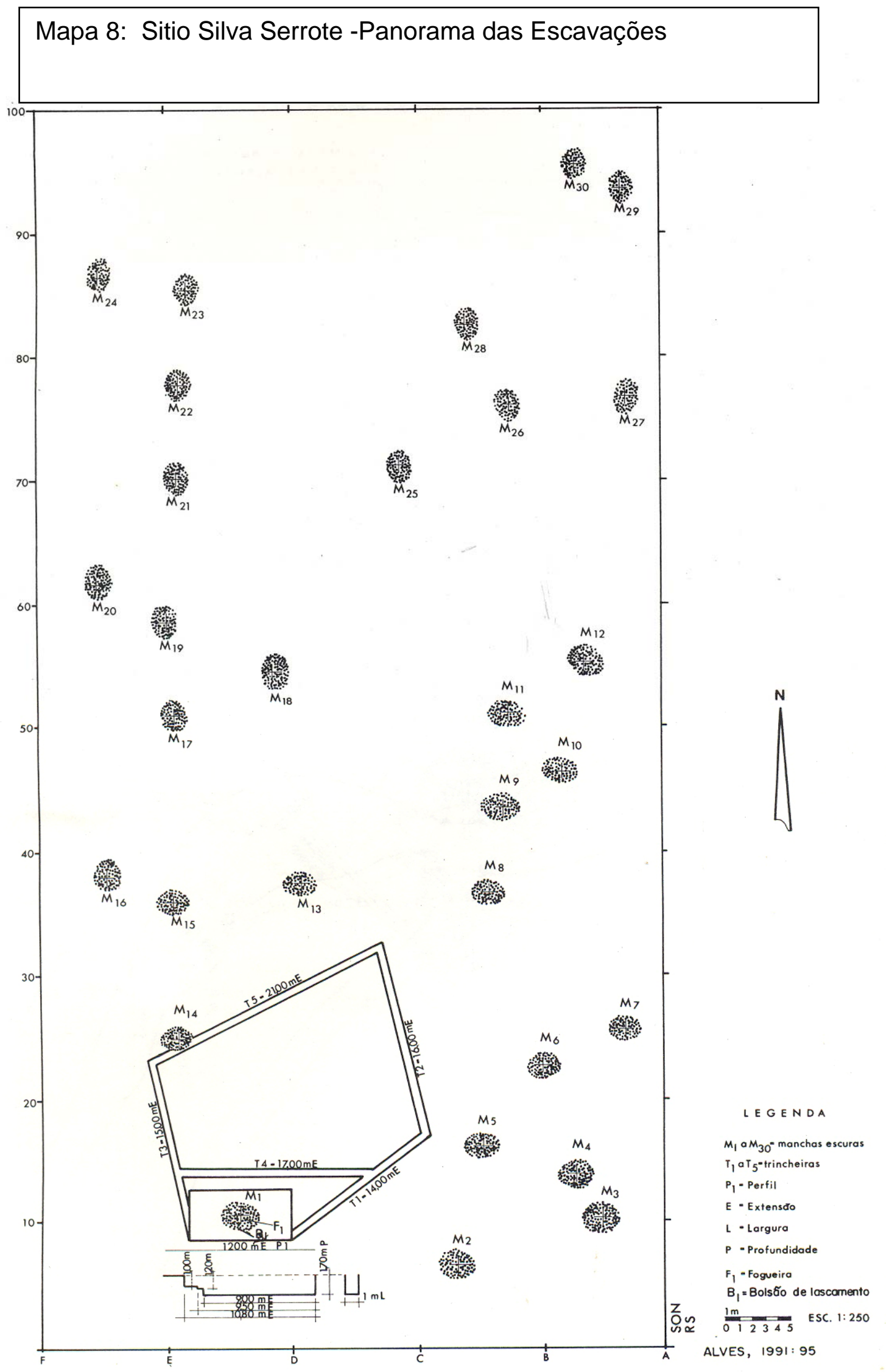


Mapa 9: sítio Silva Serrote- Croqui do Perfil 1

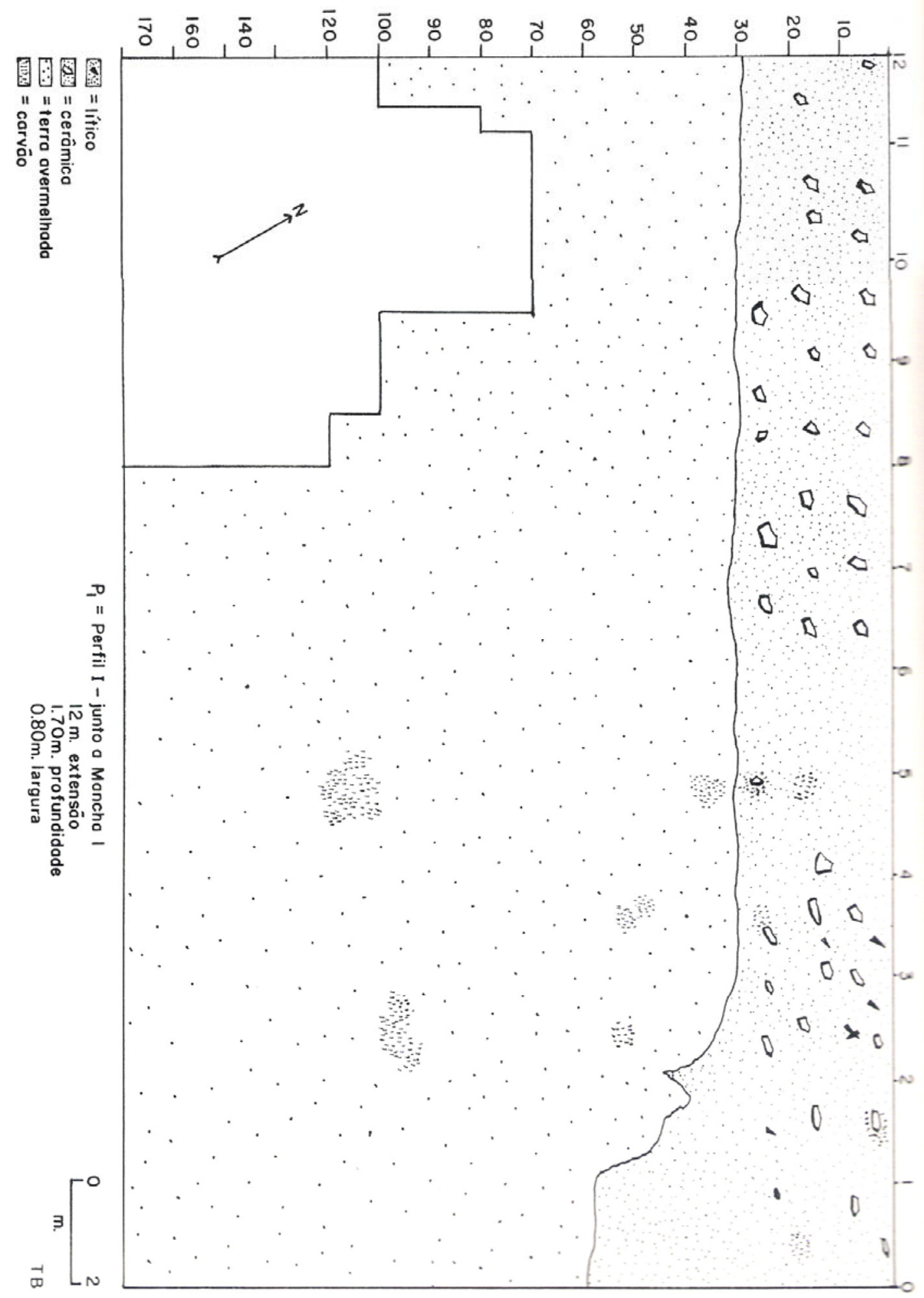

Fonte: Alves (1988). 
Mapa 10: sítio Silva Serrote- Decapagem 3 , Mancha 1

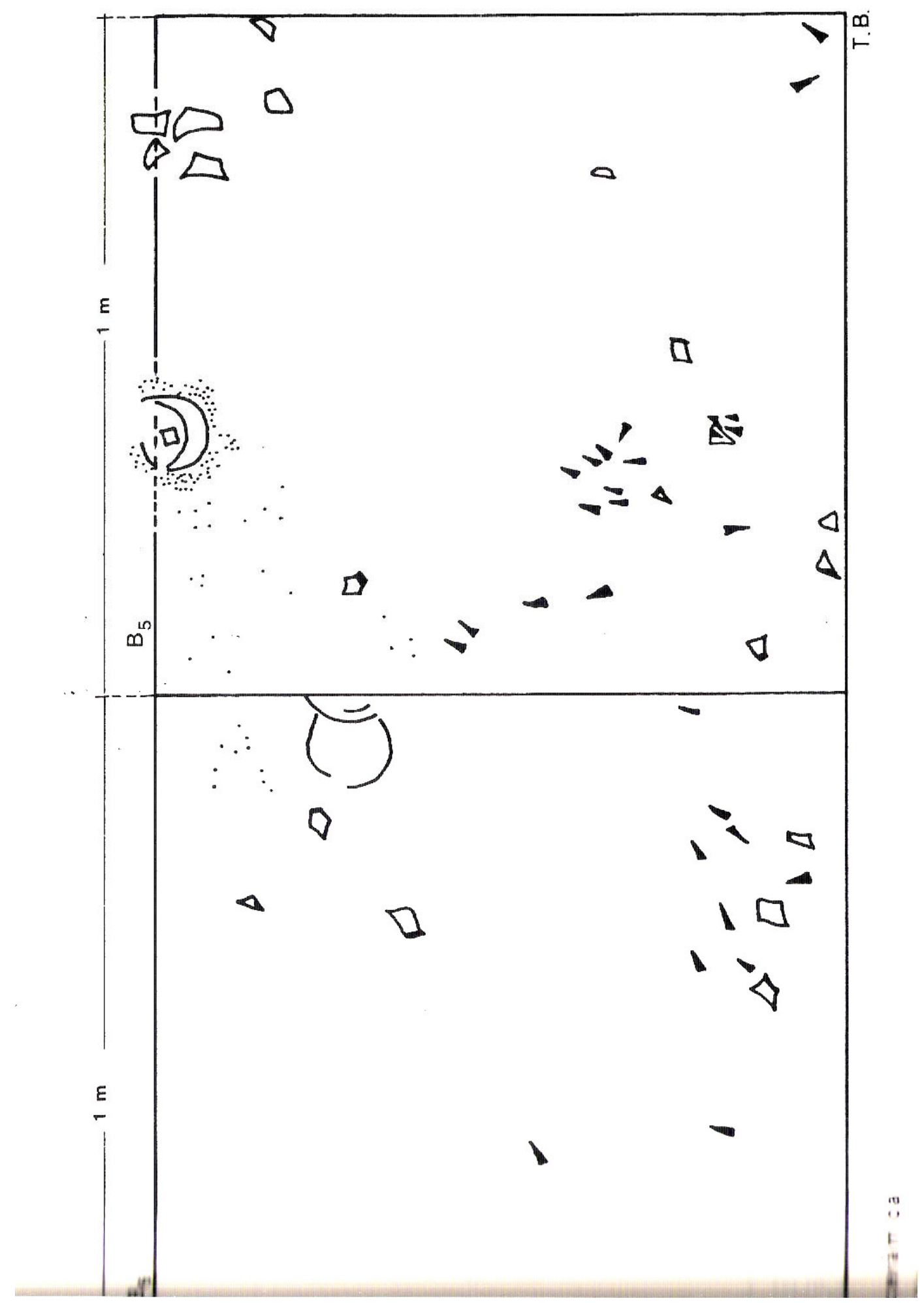

Alves(1988) 
Legenda do Mapa de Decapagem (Mapa 7)

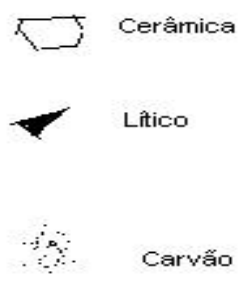

Foto 3: Siva Serrote- Perfil estratigráfico -Mancha 1/Trincheiras/Decapagem

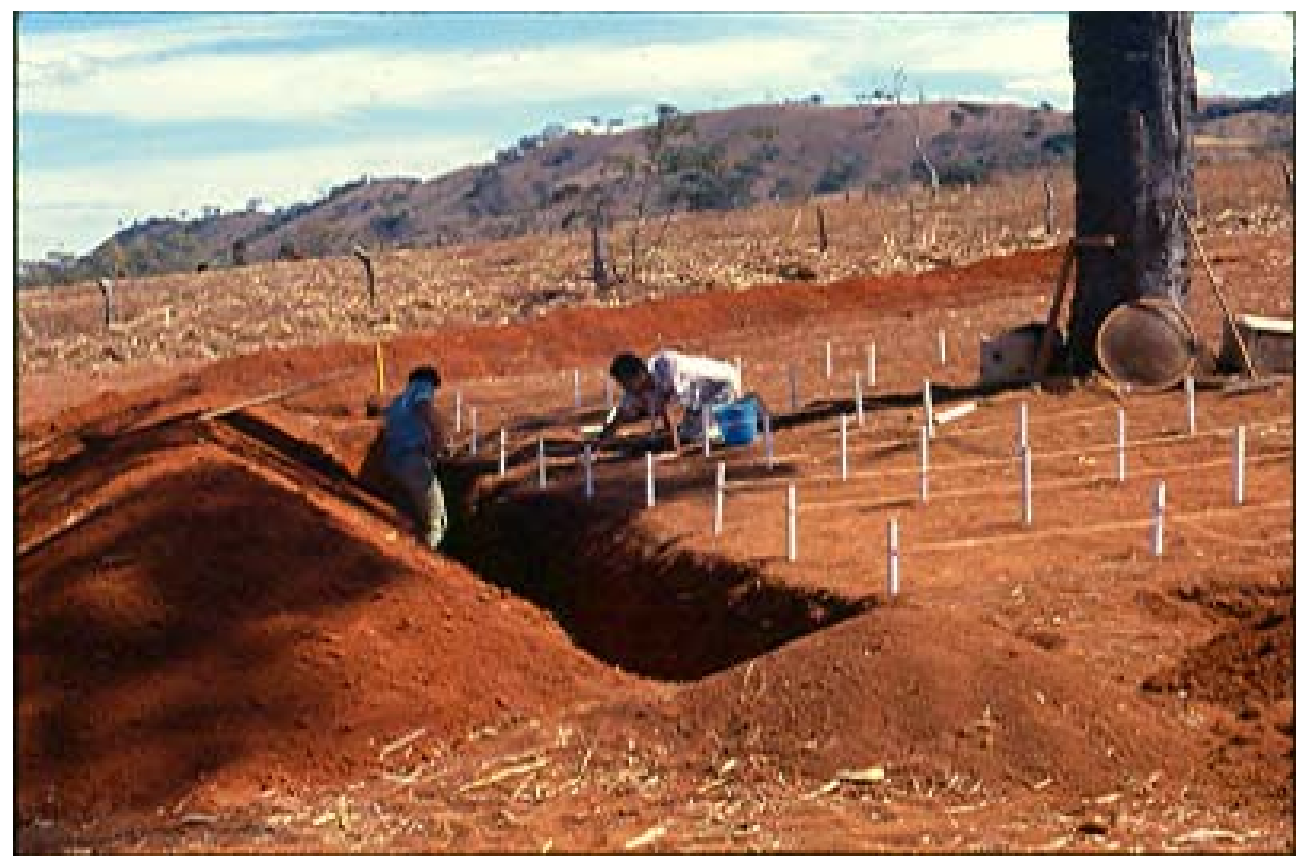

Foto: Márcia Angelina Alves ano:1985 
Foto 4: Vista Geral do sítio-início de execução das trincheiras

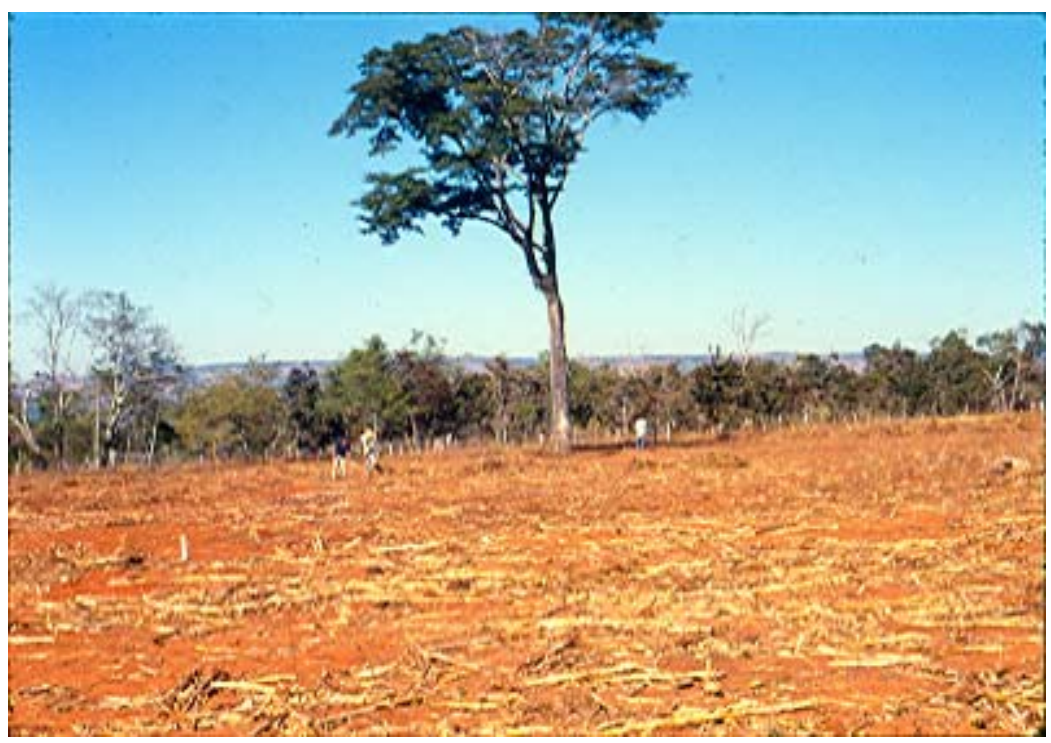

Foto:Alves. 1985.

Foto 5: decapagem por camadas naturais na mancha 1; perfil e decapagem concluídas

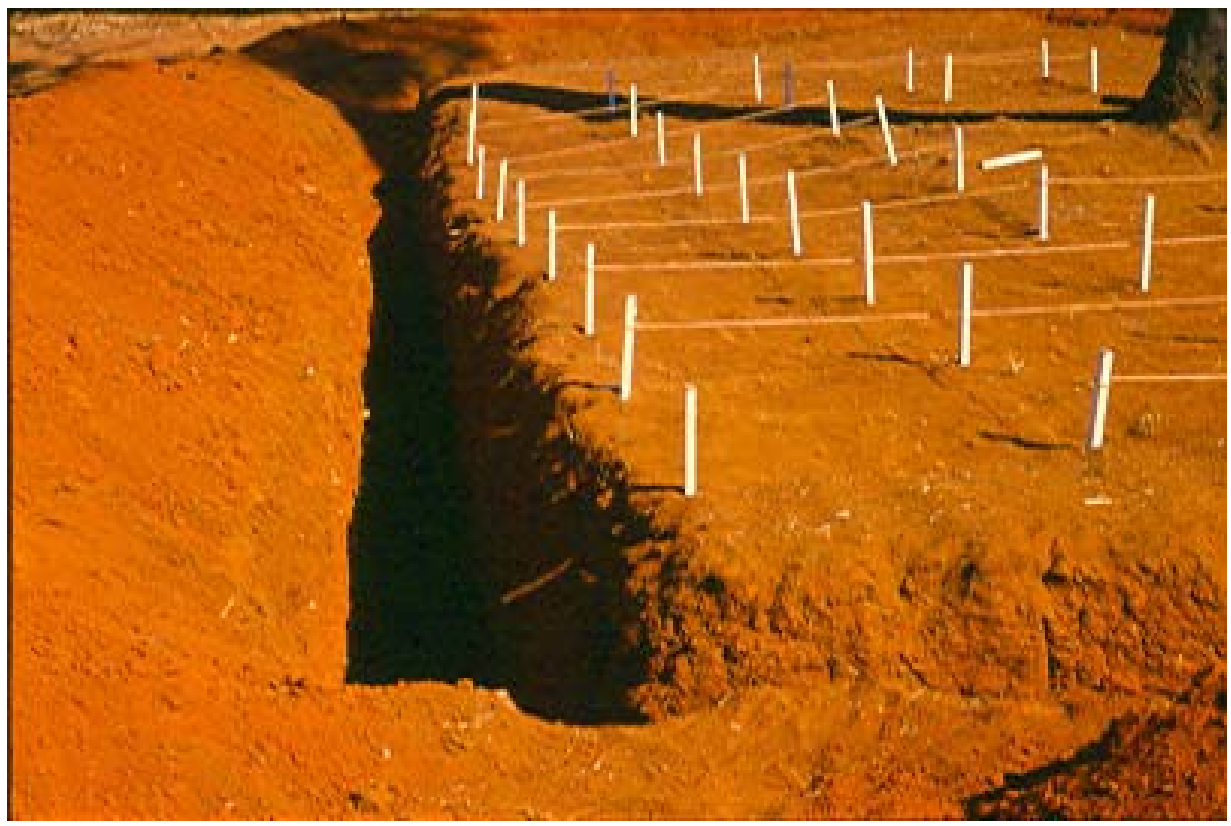

Foto:Alves,1985. 


\subsubsection{Pesquisa de campo no sítio Menezes}

A escavação no Sítio Menezes foi realizada no período de julho a agosto de 1991. Está localizado no município de Perdizes-MG como parte territorial da Fazenda São Francisco do Borja. O proprietário era o Sr. Adão Dias de Menezes(saudosa memória).

Houve uma prospecção sistemática em 1990 e que indicou a ocorrência de vestígios em uma zona arada; numa superfície de $1850 \mathrm{~m}^{2}(50 \mathrm{X} 37 \mathrm{~m})$, foi executado um perfil estratigráfico, seis trincheiras e decapagens por níveis naturais em quatro manchas escuras detectadas(espaços habitacionais).

O perfil estratigráfico foi escavado num total de 11 metros de extensão,1,5 m de largura e 1,70 de profundidade. As trincheiras abertas somatizaram 155 metros de extensão com 1,0 metro de profundidade. As decapagens executadas por níveis naturais nas quatro manchas proporcionaram os seguintes resultados:

Zona arada(M1, M2 e M4)- cerâmica muito fragmentada

Zona intacta(M3 e P1) - cerâmica pouco fragmentada .

Foi realizada uma prospecção próxima ao sítio e que propiciou a localização de afloramento rochoso, apto como fonte de matéria-prima para o lascamento.

A datação atribuída ao Menezes é de $572 \pm 80$ anos A.P., obtida por termoluminescência no IF-USP(Alves, 2002) .

Estruturas de habitação

Em uma superfície de $1850 \mathrm{~m}^{2}(50 \mathrm{X} 37 \mathrm{~m})$, foram evidenciadas quatro manchas escuras (Mapa 11).

Estruturas de combustão

Ocorrência de fogueira circular externas às habitações e associada ao bolsão de lascamento detectada na trincheira 6(Mapa 11).

Estruturas de lascamento

Ocorrência de blocos debitados, núcleos em quartzo e arenito silicificados, associados a lascas (sem retoque e retocadas) na mancha 3 e 4; lascas e estillhas em quartzo foram encontradas na trincheira 3 ,

Estruturas de polimento

Foram coletados artefatos polidos: lâminas de machado, mão-de-pilão e seixos na superfície. 


\section{Estrutura de concentração cerâmica}

Foram evidenciadas concentrações de fragmentos de cerâmica junto a fogueira circular interna a mancha escura(Foto 4). Um pote cerâmico fragmentado foi evidenciado na trincheira 4 ; dois fusos perfurados e um cuscuzeiro fragmentado foram coletados na aragem para o plantio e outro fragmento de cuscuzeiro junto à Mancha 3.

Foto 6: Sítio Menezes- Decapagem

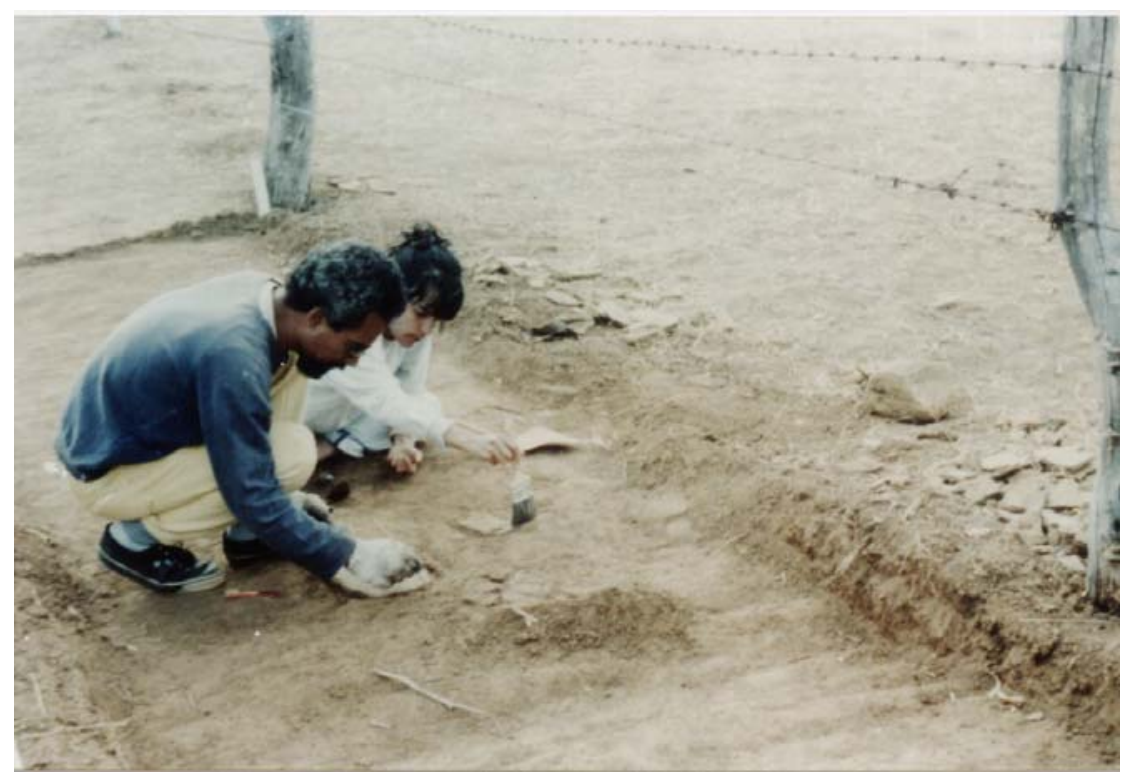

Foto: Alves,1991. 
Foto:7 Sítio Menezes -Trincheiras em leque

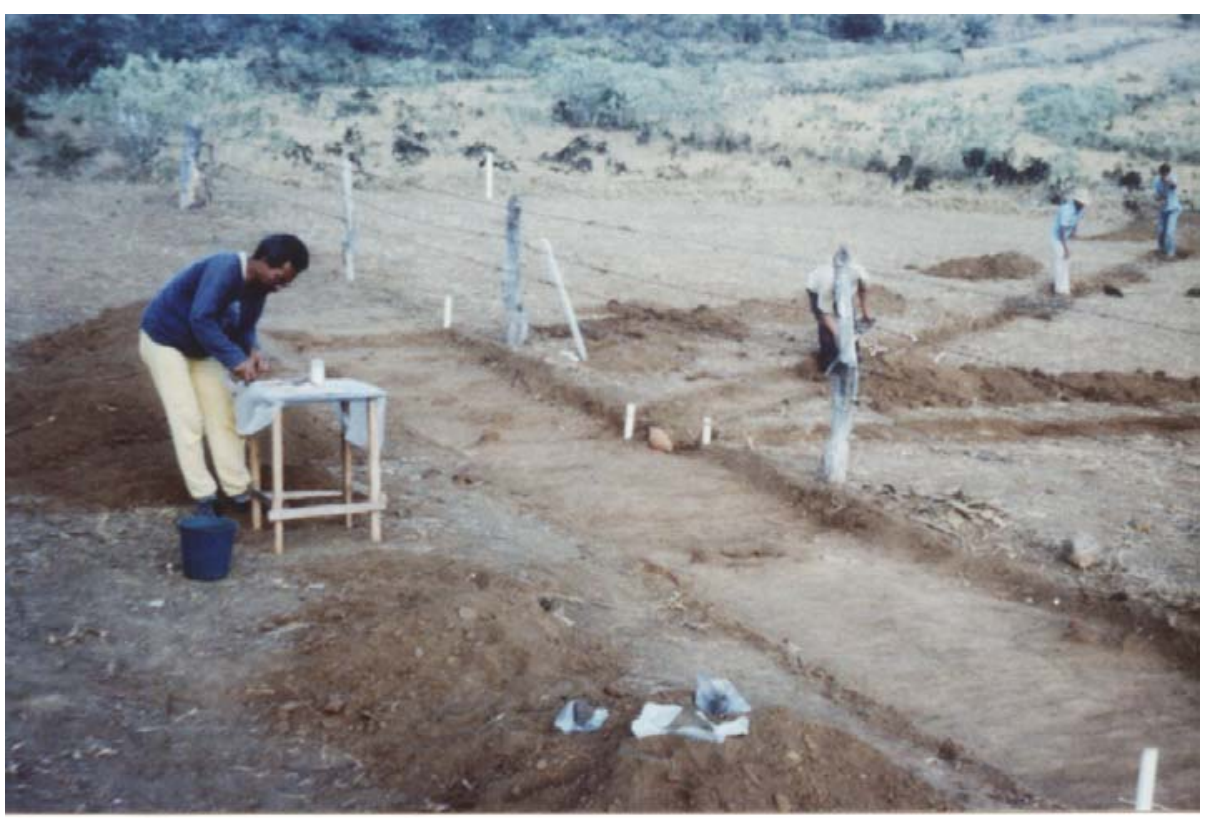

Foto: Alves, 1991.

Foto 8: Sítio Menezes-Perdizes-MG

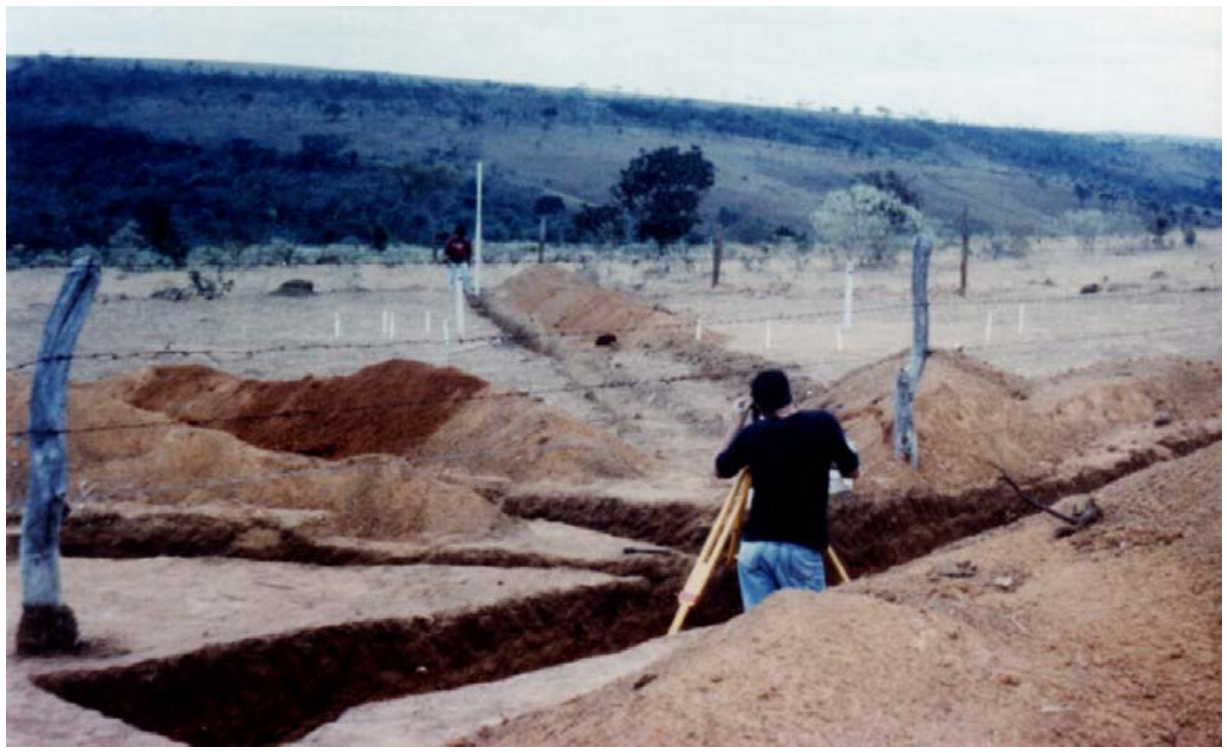

Foto: Alves ,1991 
Foto 9: Sítio Menezes -Decapagem Mancha 3

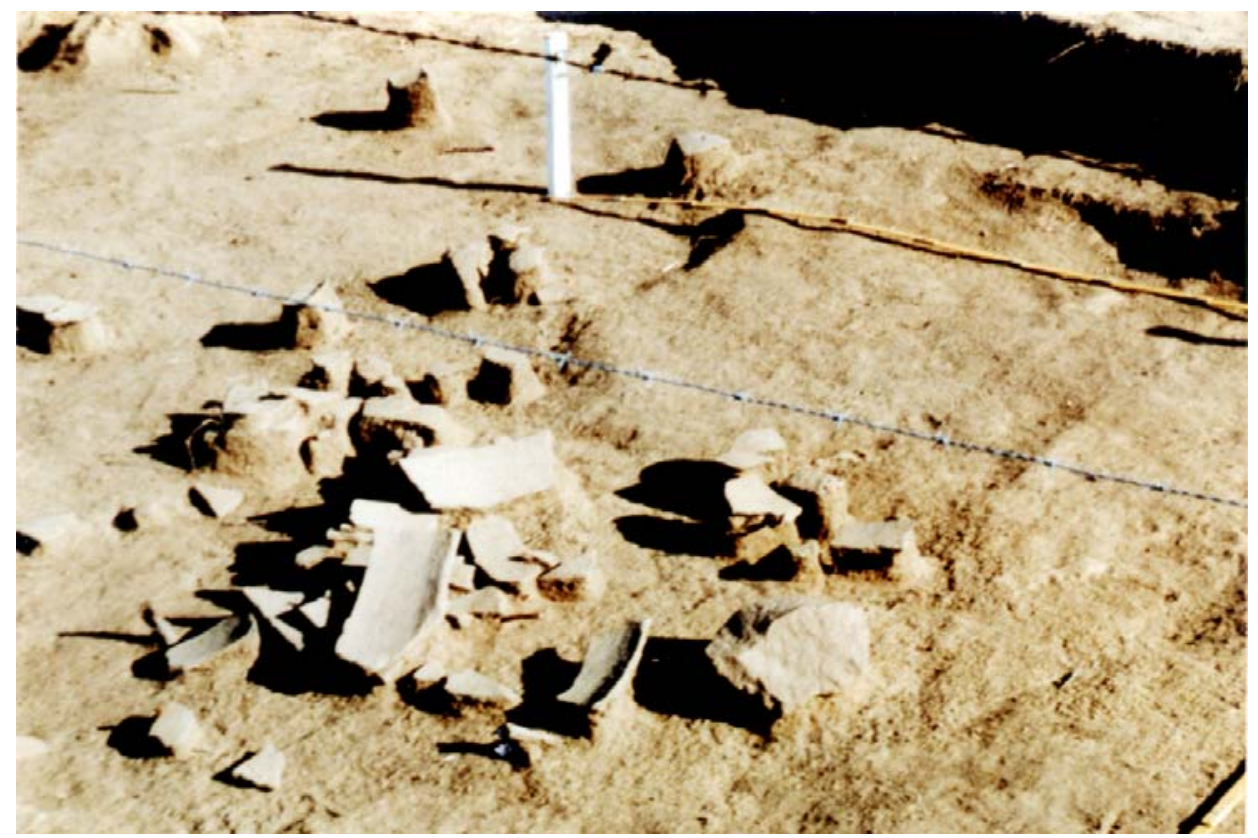

Foto: Alves ,1991

Foto 10: Sítio Menezes- execução do perfil e evidenciação

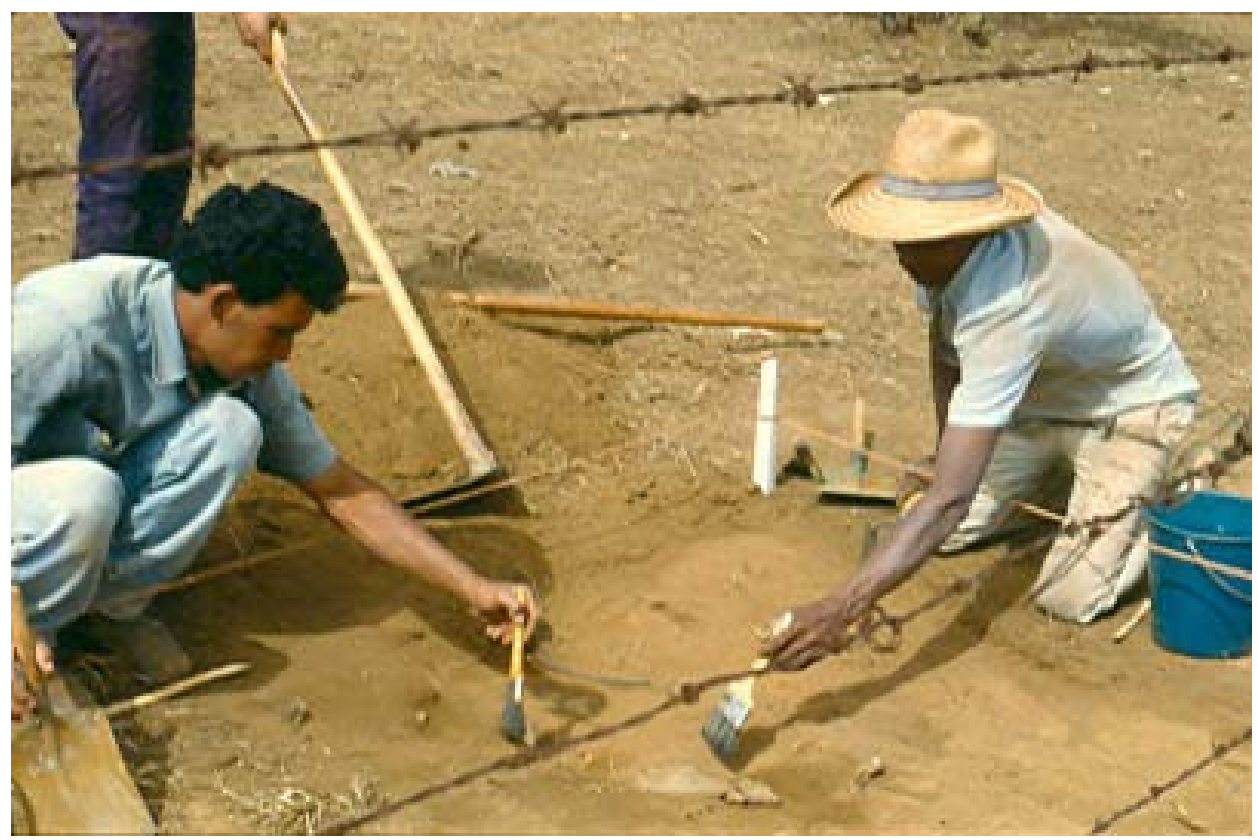

Foto:Alves. 1991. 
Foto 11: Sítio Menezes- perfil/ remontagem de vestígios

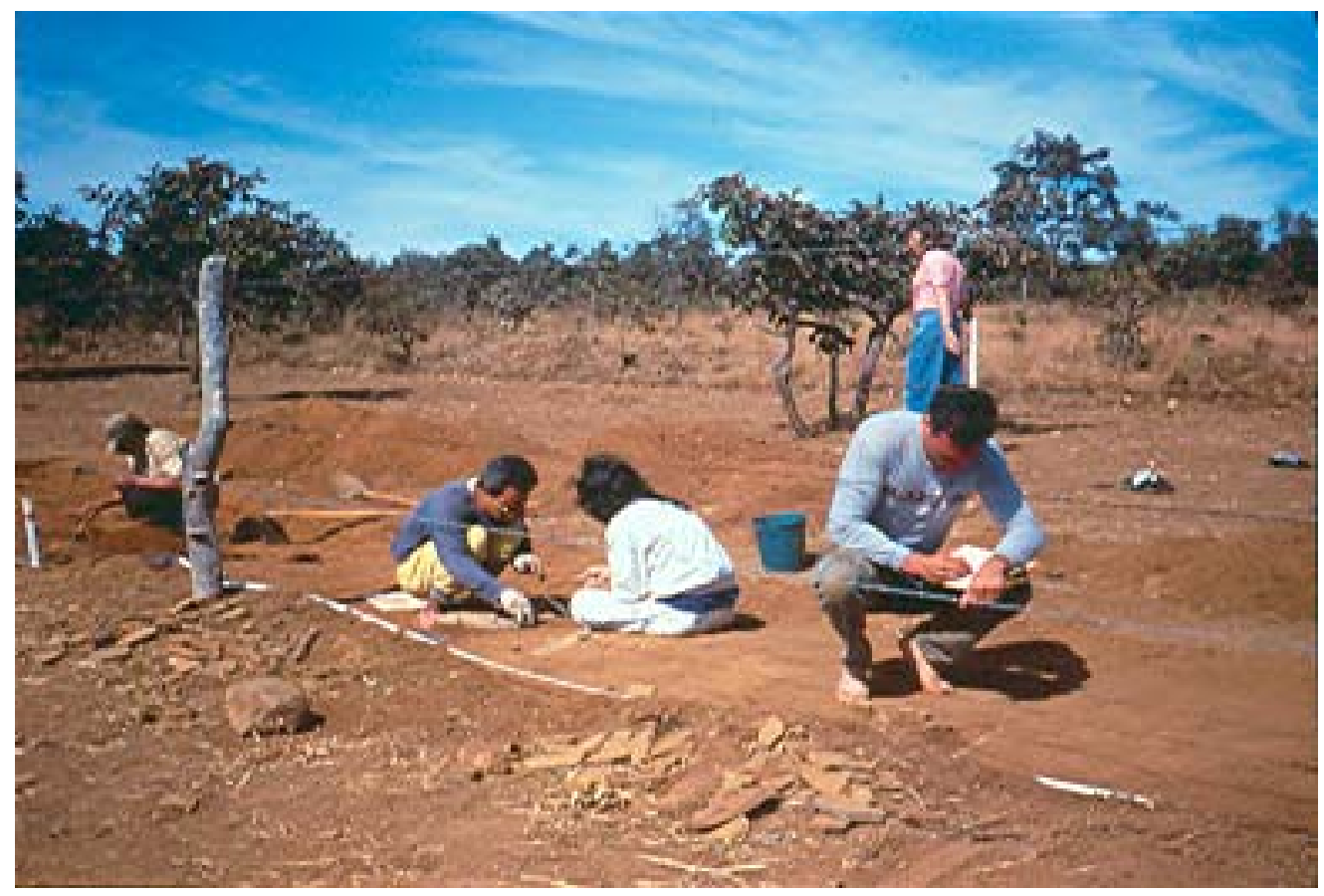

Foto: Alves. 1991.

Foto 12: Sítio Menezes- extensão do perfil

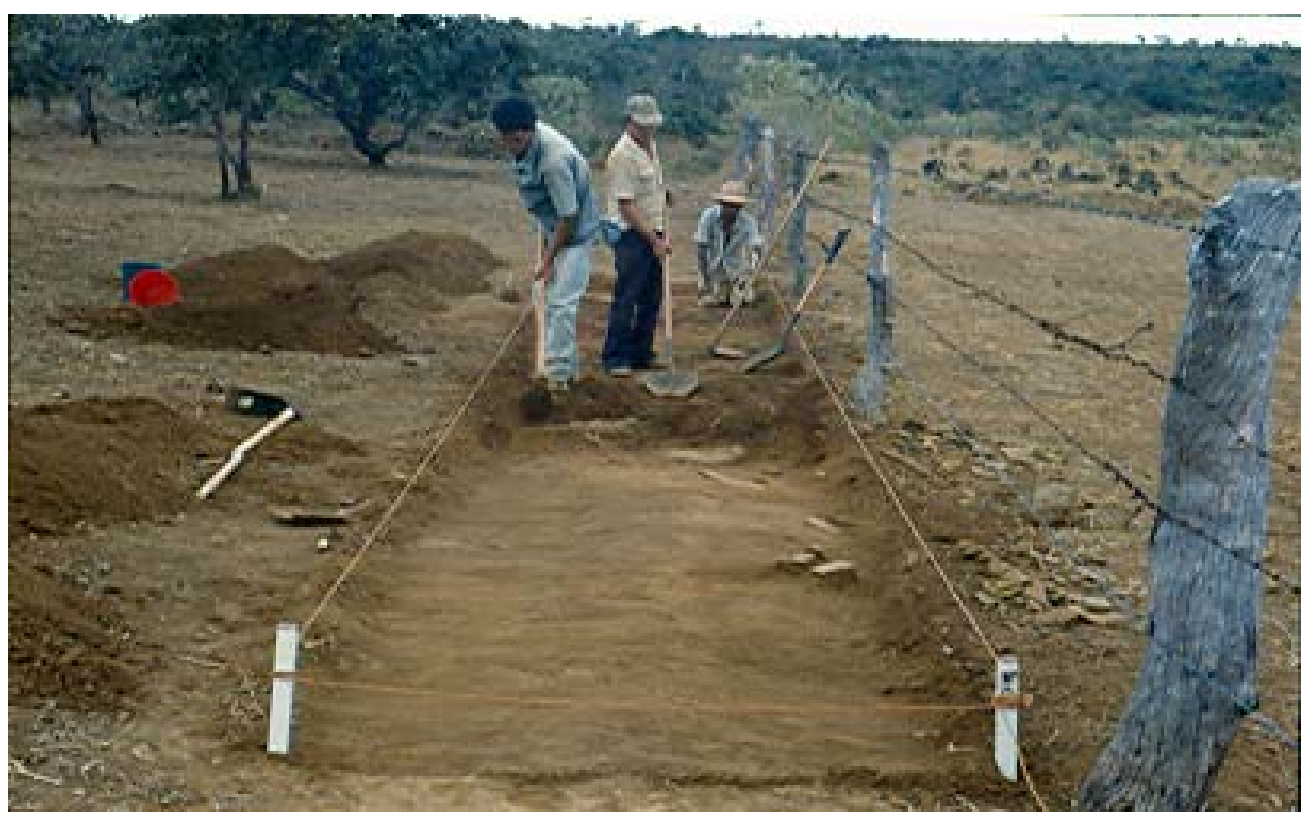

Alves, 1991. 
Foto 13: Sítio Menezes- perfil 11 m de extensão; 1,50 largura e 1,70 m profundidade

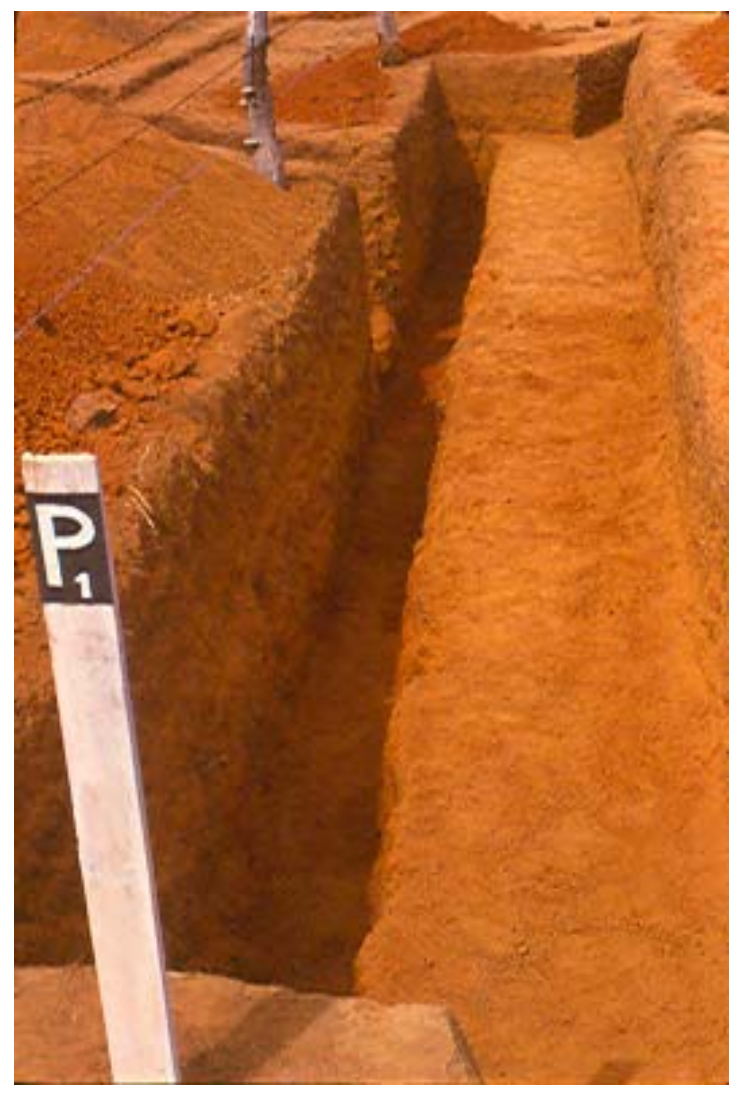

Alves, 1991

Foto 14:Sítio Menezes: decapagem da mancha 1

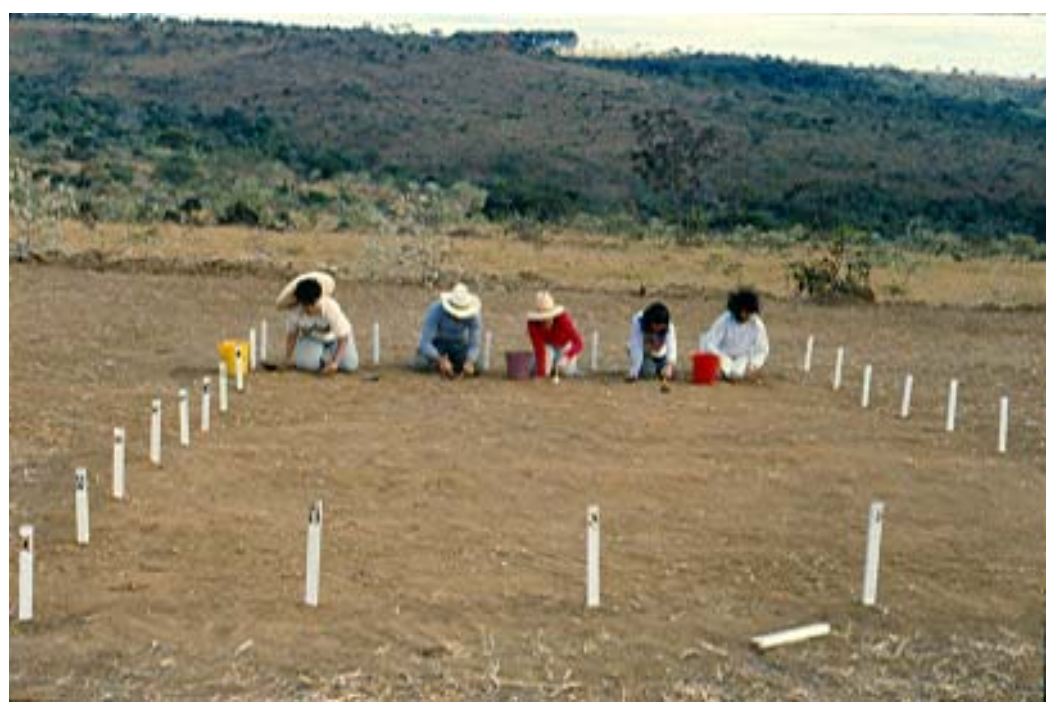

Alves,1991 
Mapa 11- Sítio Menezes- Perdizes- MG Panorama de Escavações-Aldeia Pré-histórica-1991.

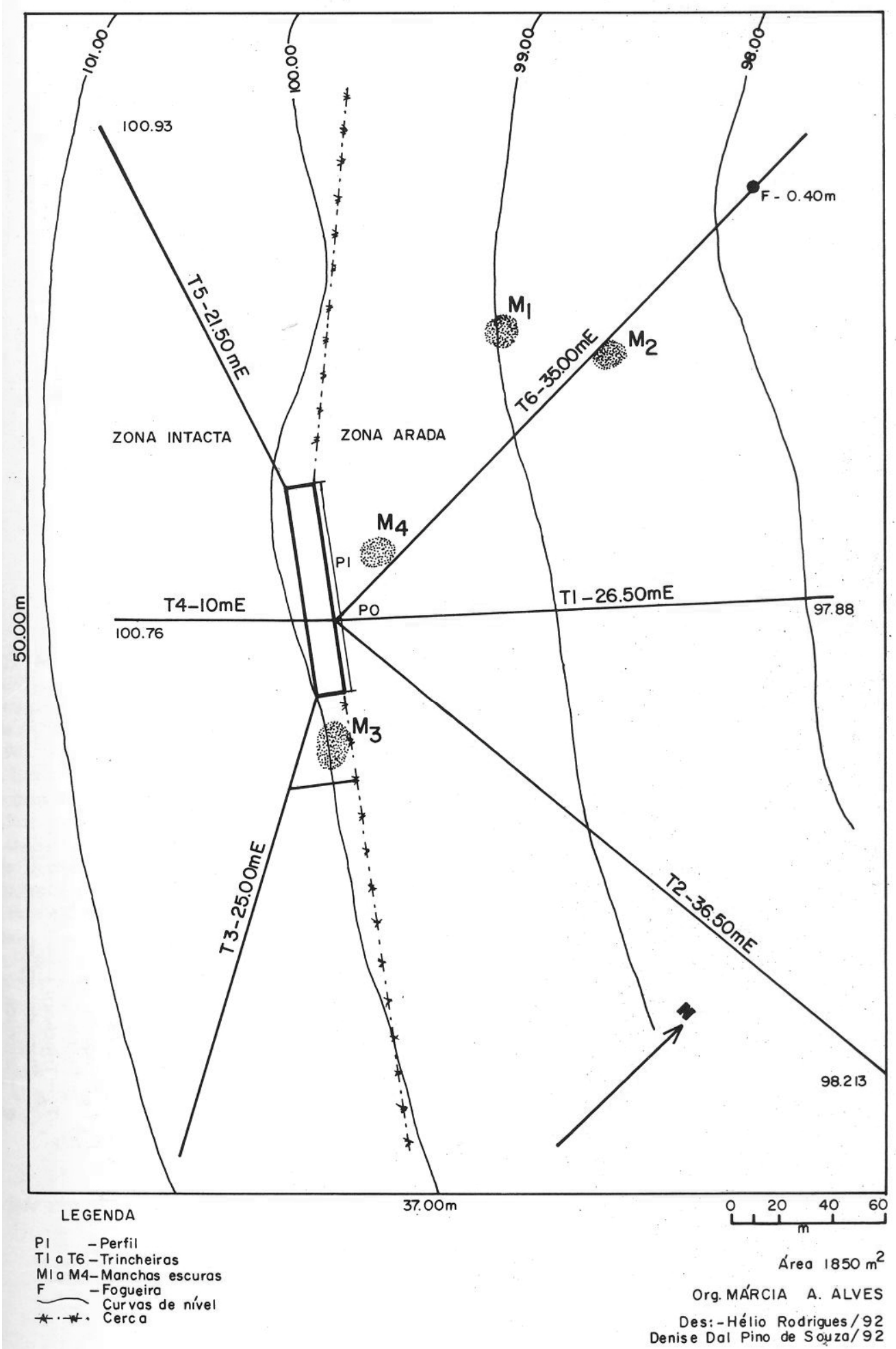

Alves,1992. 


\section{Capítulo 3: Cadeia operatória da indústria lítica do sítio Menezes e do sítio Silva Serrote}

\subsection{Análise tecnológica da indústria lítica do sítio Silva Serrote}

A cultura material lítica coletada no Sítio Silva Serrote por escavações sistemáticas do projeto Quebra-Anzol possui em sua maioria peças lascadas ${ }^{1}$. Os tipos de rochas utilizadas para a produção são o quartzo, o arenito silicificado e o sílex/ tembetá.(tabela 1).

A técnica de lascamento utilizada é o lascamento direto, unipolar e com percutor duro, pois há a preparação do núcleo com descorticamento prévio ao lascamento(tabela 4)

O número total de peças analisadas é de 703 . Dentre o total, 643 peças $(91,46 \%)$ foram confeccionadas em quartzo e 60 (8,54\%) em arenito silicificado.

Foram diagnosticados quatro tipos na produção lítica: núcleos, lascas, raspadores e estilhas. Este sítio possuía certamente uma produção ativa de artefatos, pois número de estilhas (peças de natureza acidental) é significativo, assim como de núcleos (peças preparatórias)- tabela 1.

Poucas peças apresentam retoque, apenas duas lascas em quartzo e uma lasca em arenito. A localidade do sítio que apresenta maior quantidade de peças líticas é a mancha 1; a maior parte das estilhas também se encontra nessa mancha(tabela 1 e 2).

Foram analisados 95 núcleos em quartzo, 35 núcleos em arenito silicificado ,525 estilhas em quartzo, 16 estilhas de arenito silicificado, 23 lascas de quartzo, 4 lascas de arenito silicificado e 5 raspadores em arenito.

As peças que apresentam marcas de uso são apenas os raspadores(tabela 3).

As matérias -primas utilizadas para a confecção dos artefatos foram encontradas na região, pois a formação geológica em que se encontra o sítio Silva serrote proporciona afloramentos de quartzo e arenito.

A região possui afloramentos de quartzo e cascalheiras de arenito silicificado e sílex. e O tembetá expressa emprego social simbólico, demonstrado por analogia etnográfica com povos indígenas da atualidade (Campos, 2007).

\footnotetext{
${ }^{1}$ Foram coletados previamente à escavação uma mão-de-pilão, um almofariz e uma lâmina de machado polida pelo proprietário da fazenda Serrote, e não foram entregues à pesquisadora.
} 
Tabela 1: Peças analisadas $X$ quantidade $X$ distribuição Espacial

\begin{tabular}{|c|c|c|c|c|c|c|c|c|}
\hline Tipo & Material & $\begin{array}{c}\text { Freqüênci } \\
\text { a Total } \\
\text { das peças }\end{array}$ & $\begin{array}{c}\text { Freqüênci } \\
\text { a Mancha } \\
1\end{array}$ & $\begin{array}{l}\text { Freqüênci } \\
\text { a Perfil } 1 \\
\text { Mancha } 1\end{array}$ & $\begin{array}{c}\text { Freqüênci } \\
\text { a } \\
\text { Trincheira } \\
1\end{array}$ & $\begin{array}{c}\text { Freqüênci } \\
\text { a } \\
\text { Trincheira } \\
2\end{array}$ & $\begin{array}{c}\text { Freqüênci } \\
\text { a } \\
\text { Trincheira } \\
3\end{array}$ & $\begin{array}{c}\text { Freqüên } \\
\text { cia } \\
\text { Trincheir } \\
\text { a } 4\end{array}$ \\
\hline Núcleo & quartzo & 95 & 30 & 31 & 6 & 16 & 5 & 7 \\
\hline Núcleo & $\begin{array}{l}\text { Arenito } \\
\text { silicific } \\
\text { ado }\end{array}$ & 35 & 23 & 9 & & 0 & & 3 \\
\hline Estilha & Quartzo & 525 & 283 & 209 & 6 & 12 & 3 & 17 \\
\hline Estilha & $\begin{array}{l}\text { Arenito } \\
\text { silicific } \\
\text { ado }\end{array}$ & 16 & 9 & 4 & 0 & 1 & & 2 \\
\hline Lasca & Quartzo & 23 & 12 & 2 & 1 & 0 & & \\
\hline Lasca & $\begin{array}{l}\text { Arenito } \\
\text { silicific } \\
\text { ado }\end{array}$ & 4 & 3 & 1 & 0 & 0 & & \\
\hline $\begin{array}{l}\text { Raspa } \\
\text { dor }\end{array}$ & $\begin{array}{l}\text { Arenito } \\
\text { silicific } \\
\text { ado }\end{array}$ & 5 & 3 & 1 & 0 & 1 & & \\
\hline Total & - & 703 & 363 & 257 & 13 & 30 & 8 & 31 \\
\hline$\%$ & & $100 \%$ & $51,63 \%$ & $35,55 \%$ & $1,84 \%$ & $4,26 \%$ & $1,13 \%$ & $4,40 \%$ \\
\hline
\end{tabular}

A tabela 1 descreve as principais fontes de matéria-prima utilizadas e sua freqüência de uso nas áreas escavadas. O quartzo foi material mais utilizado foi o quartzo e a região do sítio mais abundante em artefatos é a Mancha 1 e perfil 1.

Tabela 2: Peças com retoque

\begin{tabular}{|c|c|c|}
\hline Tipo & Material & Localização \\
\hline Lasca & quartzo & Mancha 1 \\
\hline Lasca & quartzo & Mancha 1 \\
\hline Lasca & arenito & Mancha 1 \\
\hline raspador & Arenito & Mancha 1 \\
\hline Total & - & $\mathbf{4}$ \\
\hline
\end{tabular}


A tabela 2 apresenta o número de peças com retoque. Apenas 3 lascas apresentaram retoque, do tipo em escamas denticulado, que originaram formas largas e curtas.

A análise dos retoques está relacionada aos traços de utilização que alcançam níveis máximos na definição do artefato lítico.(Morais 1983).

Tabela 3: Peças com marca de uso

\begin{tabular}{|l|l|l|}
\hline Tipo & Material & Localização \\
\hline raspador & Arenito silicificado & Mancha 1 \\
\hline raspador & Arenito silicificado & Mancha 1 \\
\hline raspador & Arenito silicificado & Mancha 1 \\
\hline raspador & Arenito silicificado & Trincheira 2 \\
\hline Raspador frontal & Arenito silicificado & Mancha 1 Perfil 1 \\
\hline Total & - & 5 \\
\hline
\end{tabular}

Dentre os artefatos da coleção, apenas os raspadores apresentaram marca de uso; os cinco raspadores do sítio apresentação marcas de uso.

Tabela 4: Lascas de descorticamento

\begin{tabular}{|l|l|}
\hline Lascas de descorticamento & Freqüência \\
\hline Arenito & 3 \\
\hline Quartzo & 22 \\
\hline Total & 25 \\
\hline
\end{tabular}

Após a primeira retirada que origina a lasca inicial, outras lascas são retiradas (lascas de descorticamento). A face externa geralmente apresenta o negativo das retiradas precedentes e parte do córtex. Podem ser utilizadas ou abandonadas no mesmo local de debitagem ou ainda retocadas e utilizadas. 
Tabela 5: Lascas corticais

\begin{tabular}{|l|l|}
\hline Lascas corticais & Freqüência \\
\hline Arenito & 2 \\
\hline Quartzo & 0 \\
\hline Total & 2 \\
\hline
\end{tabular}

As lascas corticais possuem face externa que apresenta um córtex, resquício da superfície original da rocha.

\section{Definições técnicas dos artefatos encontrados(Souza, 1997)}

Bloco: Massa destacada da rocha mãe, não apresenta nenhum plano de fratura.Pode apresentar córtex em uma das faces, correspondendo à aquela que estava exposta ao ar; possui tamanho susceptível ao lascamento.

Lasca: fragmento de rocha debitado por uma percussão aplicada em um ponto determinado do núcleo.Possui uma face interna e uma face externa.

Núcleo: Bloco de matéria-prima preparada para que dele se possa retirar uma ou uma série de lascas.

Núcleo esgotado: aquele do qual não é possível tirar mais nenhuma lasca.

Raspador: utensílio de lasca ou de bloco das séries das ferramentas plano-convexas; o bordo ativo é convexo (ou mais raramente retilíneo) e forma um ângulo aberto com a face externa.

Estilhas: conjunto de lascas nas quais não se observa nem trabalho secundário, nem utilização e que foram abandonadas

Percutor:Todas as ferramentas cuja função é dar golpes para afundar, esmagar ou lascar;objeto que desempenha o papel de martelo.

Tembetá: ornamento labial de pedra polido, cilíndrico, bicônico ou triangular de lados levemente convexos. 
Foto 15: Sítio Silva Serrote -Tembetá(sílex) em forma de meia lua

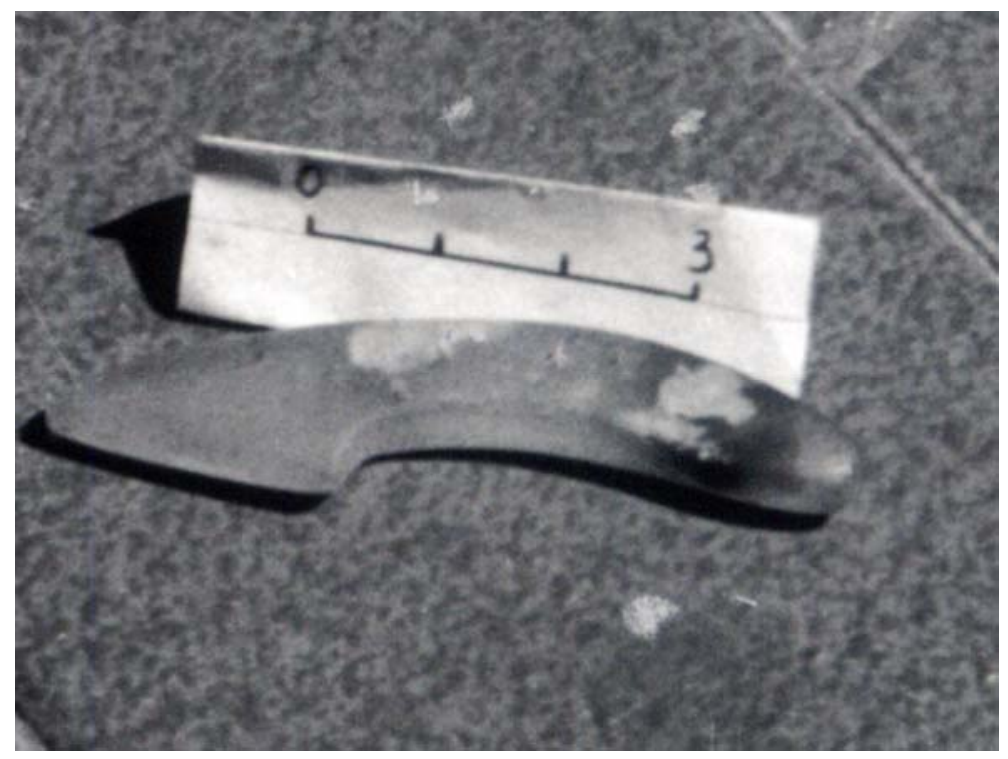

Foto: Alves, 1985.

Análise tecnológica da produção lítica do Sítio Silva Serrote e cadeia operatória

As tipologias para artefatos líticos criadas com o intuito de classificar estes materiais, são muito frágeis, pois tem de ser flexibilizadas diante da variabilidade artefatual e das realidades dos contextos arqueológicos. Para atender a essa necessidade, as tipologias tem a tendência de se tornarem cada vez mais regionais, pois o vocabulário deve ser amplo o suficiente para descrever os objetos, ao passo que deve ser preciso para que as descrições de arqueólogos com o mesmo tipo de problemas sejam comparáveis entre si; além disso, categorias como faca, raspador, machado (etc...), são definições gerais de objetos que existem em todo o mundo, ou seja, aparecem em todas as culturas e não caracterizam nenhuma (Laming- Emperaire, 1967), fato que corrobora a necessidade de regionalização e de especificidade das tipologias.

A cadeia operatória do lascamento tem início com a busca e obtenção da matériaprima. As matérias-primas utilizadas para a confecção das peças foram o arenito silicificado e o quartzo; a única exceção do material é o tembetá, confeccionado em sílex.

A região de Guimarânia possui cascacalheiras de quartzo e arenito silicificado. O quartzo é o mineral mais abundante do globo terrestre, possui dureza 7 na escala de Mohs; 
esta região também possui formação geomorfológica em que o arenito silicificado aflora, assim como o sílex.

A escolha da matéria-prima geralmente está atrelada ao emprego final da peça lítica; o arenito silicificado é um material que produz lascas com poucos golpes e gumes de fácil retoque $^{1}$, mas não produz artefatos resistentes; o quartzo é mais difícil de lascar, produz alto número de estilhas durante o lascamento e sua estrutura é otimizada quando usado como percutor ou polidor; o uso das matérias-primas da região proporcionou o domínio sobre o espaço geográfico ocupado pelo grupo(Pallestrinni, L; Morais, J.L,1982 ).

Após a escolha da matéria -prima, há a necessidade de escolha do percutor, que deve geralmente ser mais duro que a matriz. No sítio Silva Serrote, há a presença massiva de blocos em arenito e em segunda posição, o quartzo.

A partir da escolha destes dois elementos, o artesão executa o primeiro gesto(fruto das técnicas socialmente aprendidas, obtendo dessa forma três elementos: a primeira lasca, o núcleo(matriz de lascamento) e o percutor. Outros gestos seguem este primeiro, de acordo com o objeto final idealizado previamente.

Retoque

Estes movimentos supracitados produzem lascas e estilhas;algumas lascas podem ser aproveitadas para o uso, sendo retocadas e outras descartadas. Estes movimentos também produzem estilhas residuais.

As lascas aptas para o retoque podem ser trabalhadas com várias técnicas; a morfologia utilizada para os retoques no sítio Silva Serrote foi a de escamas, caracterizada por golpes que originaram formas largas e curtas; há também a morfologia do bordo retocado, e nas lascas com retoque o desenho do gume foi o denticulado. Após a obtenção da forma premeditada, a peça está pronta para o uso.

Algumas peças previamente descartadas podem ser preparadas para o uso; algumas peças já finalizadas e utilizadas podem ser reajustadas para um novo uso.

De acordo com Bleed(2001), existem diversos modelos de cadeias operatórias; no entanto, o referencial teórico e metodológico apresentados nesta dissertação, se adequam de forma mais coerente ao modelo francês. Este mesmo autor apresenta o modelo de Lemonnier com foco nos aspectos cognitivos associados com as operações tecnológicas.

\footnotetext{
${ }^{1}$ Retoque: pequenas retiradas feitas no núcleo ou nos produtos de debitagem em locais previamente escolhidos a fim de ajustar as formas a uma situação desejada(Morais, 1980).
} 
Modelo de Lemonnier descrito por Bleed (2001).

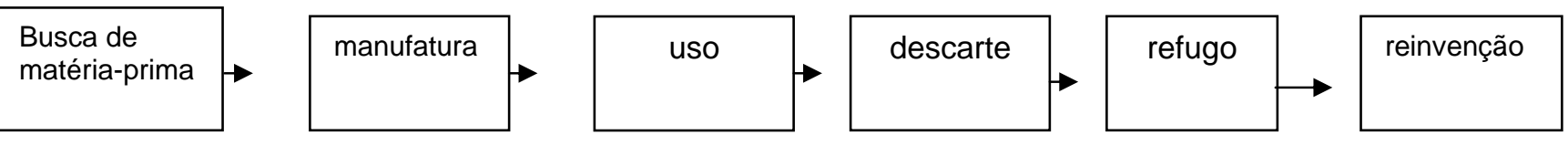

Uso social dos objetos da coleção do Sítio Silva Serrote

Tabela 6: O Uso social dos artefatos/objetos encontrados no sítio Silva Serrote

\begin{tabular}{|l|l|}
\hline Uso Social & Artefatos I objetos \\
\hline Descascar frutos pequenos & Lascas com retoques(pequenas) \\
\hline Raspar o couro e tubérculos & Raspador \\
\hline Rito de passagem(adulto) & Tembetá \\
\hline $\begin{array}{l}\text { Resíduos acidentais e peças preparatórias } \\
\text { para a atividade de lascamento }\end{array}$ & Estilhas/ núcleos \\
\hline
\end{tabular}

Podemos destacar algumas atividades sociais praticadas no sítio Silva Serrote:

O raspador remete à atividade de raspar ou trabalhar o couro e o descascamento de tubérculos.

As lascas pequenas, com retoques sugerem o descascamento de frutos.

O tembetá sugere ornamentação labial que marca algum rito de passagem, gênero ou outro evento de importância social.

A presença dos núcleos e das estilhas são indicadores de atividade de lascamento intra-sítio. 
Foto 16: Estilhas em quartzo

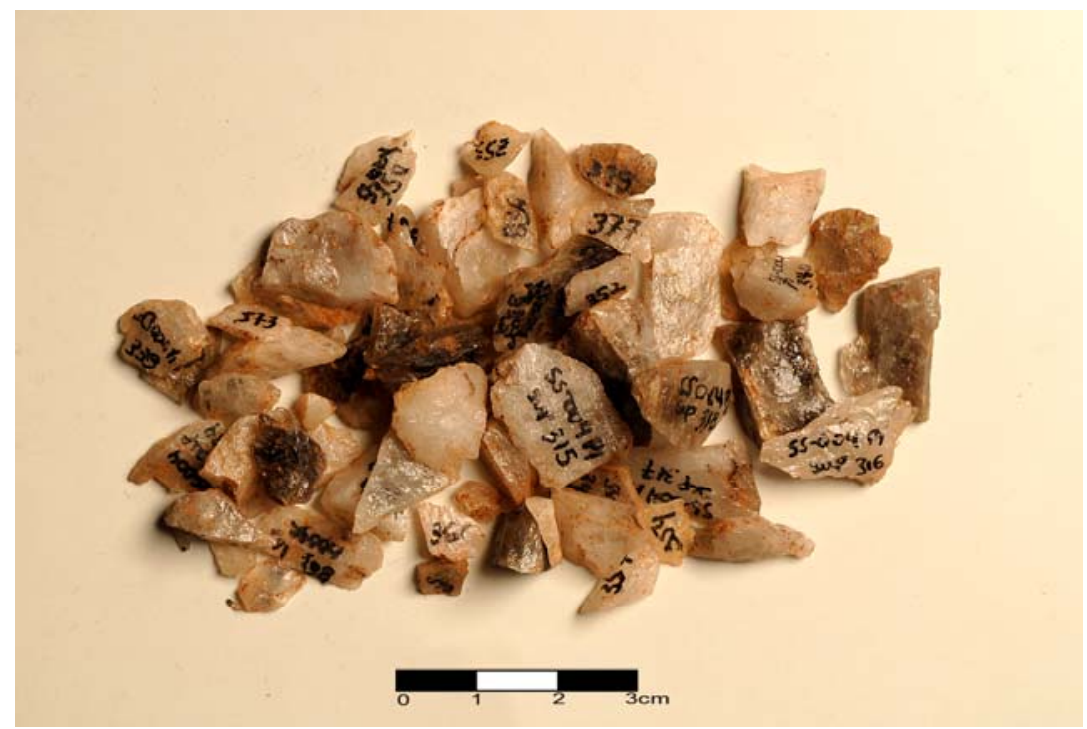

Foto: Souza, 2008.

Foto 17: Lasca - arenito silicificado

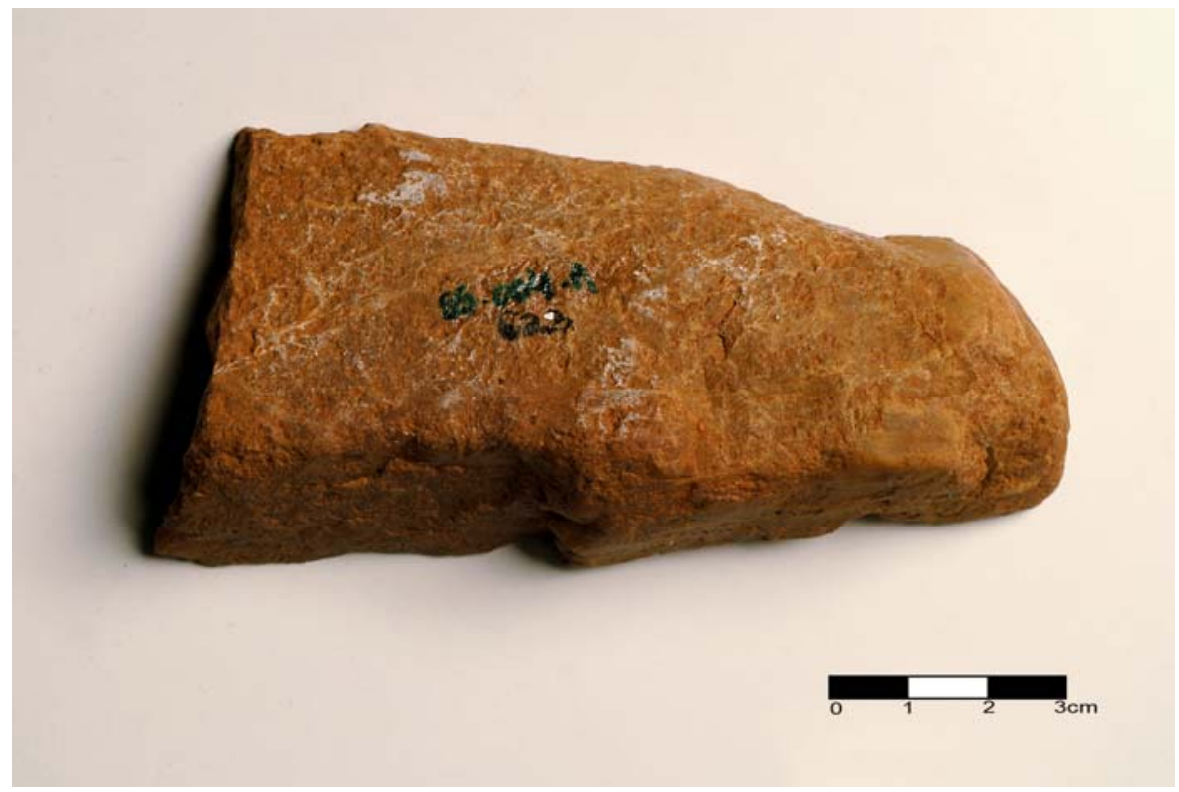

Foto: Souza, 2008. 
Foto 18: Estilhas em quartzo

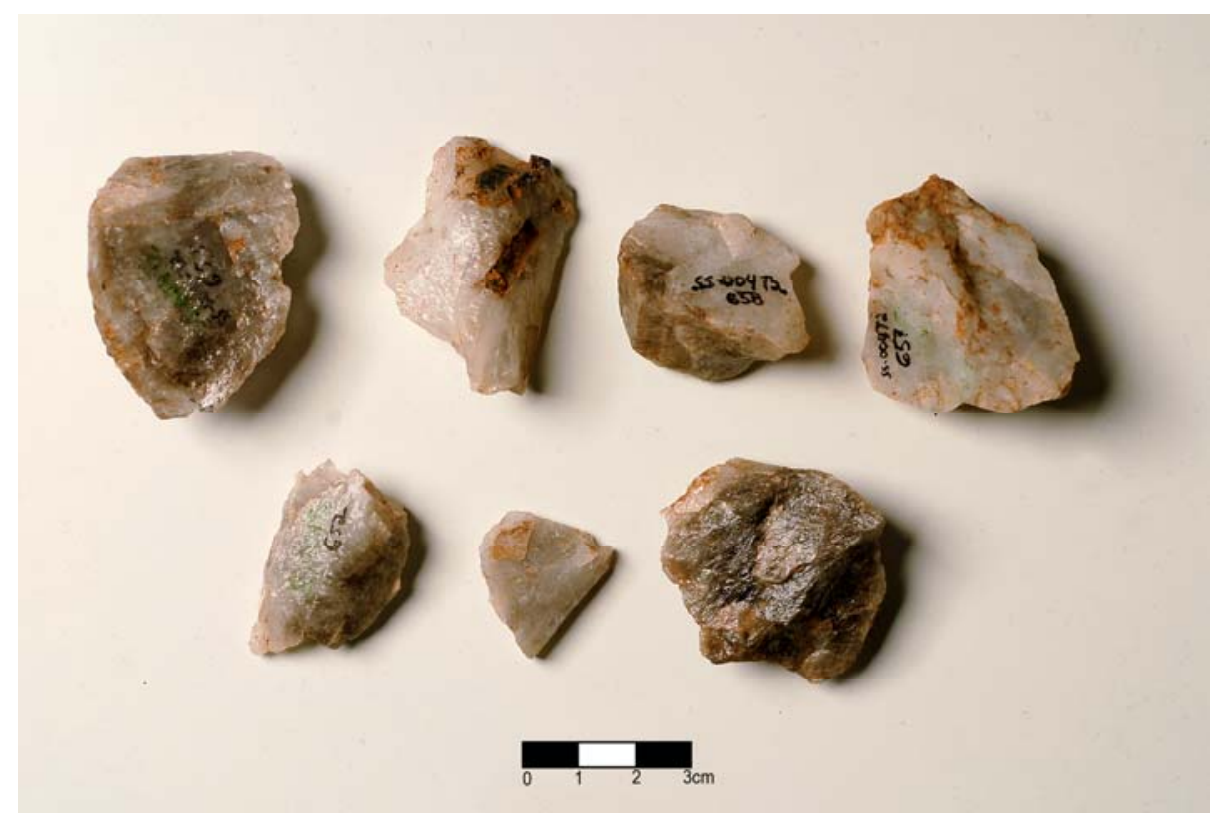

Foto: Souza, 2008.

Foto 19: Raspador em arenito silicificado

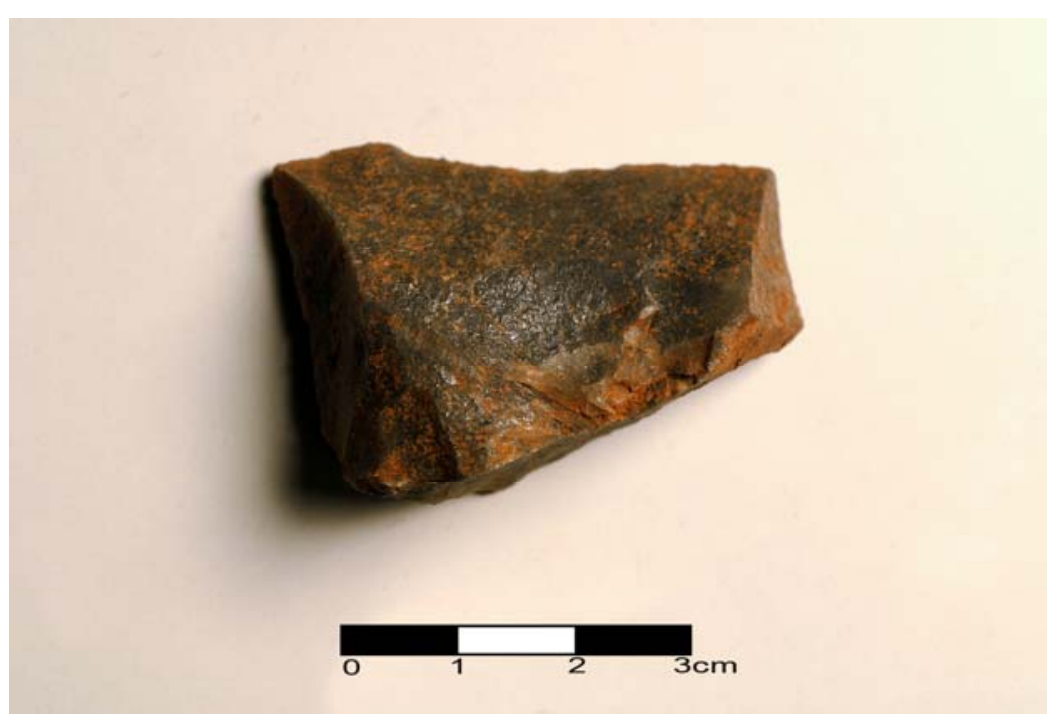

Foto: Souza, 2008. 
Foto 20: Raspador em arenito silicificado

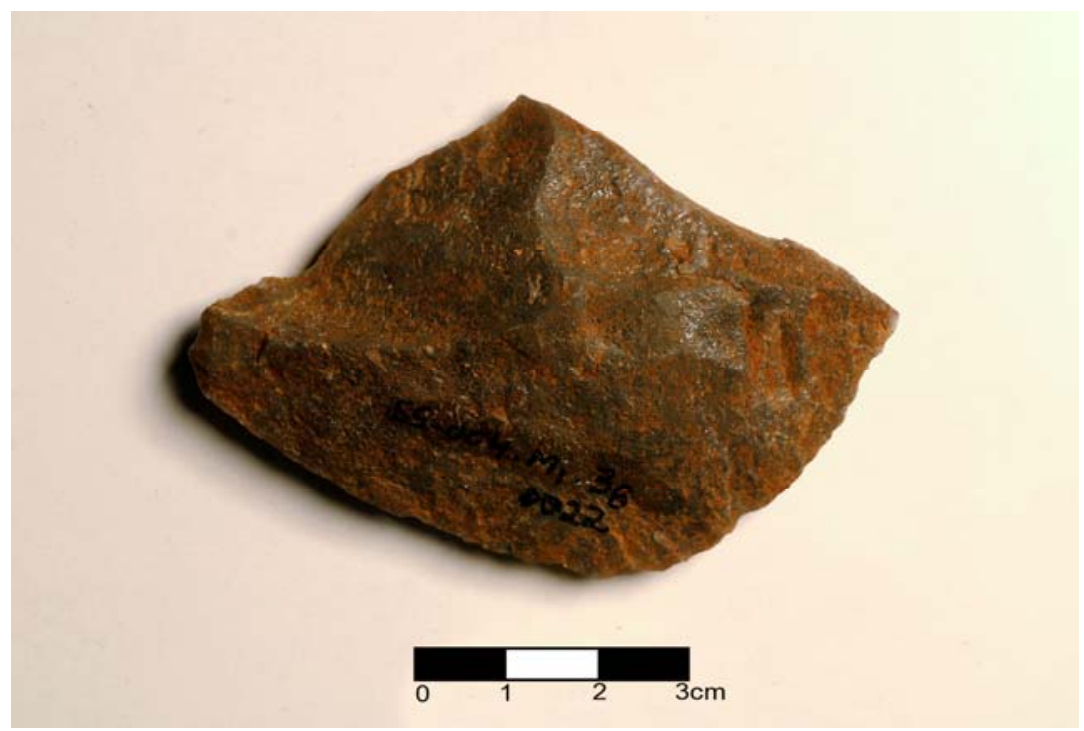

Foto: Souza, 2008.

Foto 21: Lasca - arenito silicificado

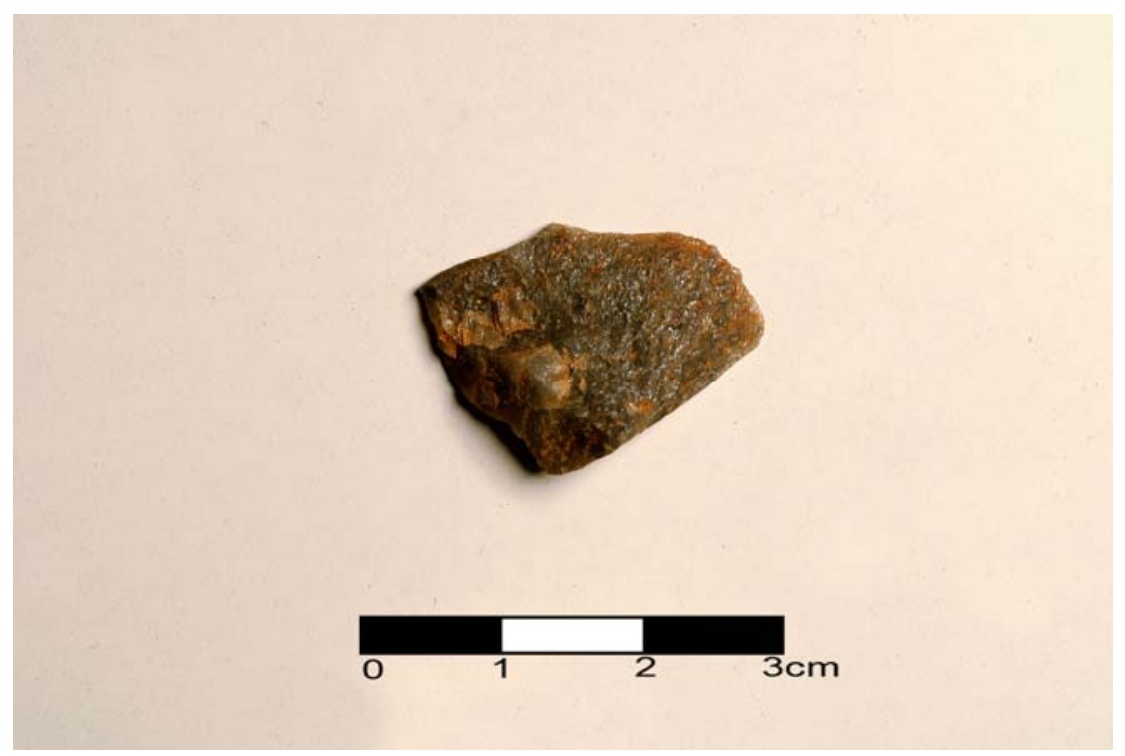

Foto:Souza,2008 
Foto 22: Núcleo -quartzo

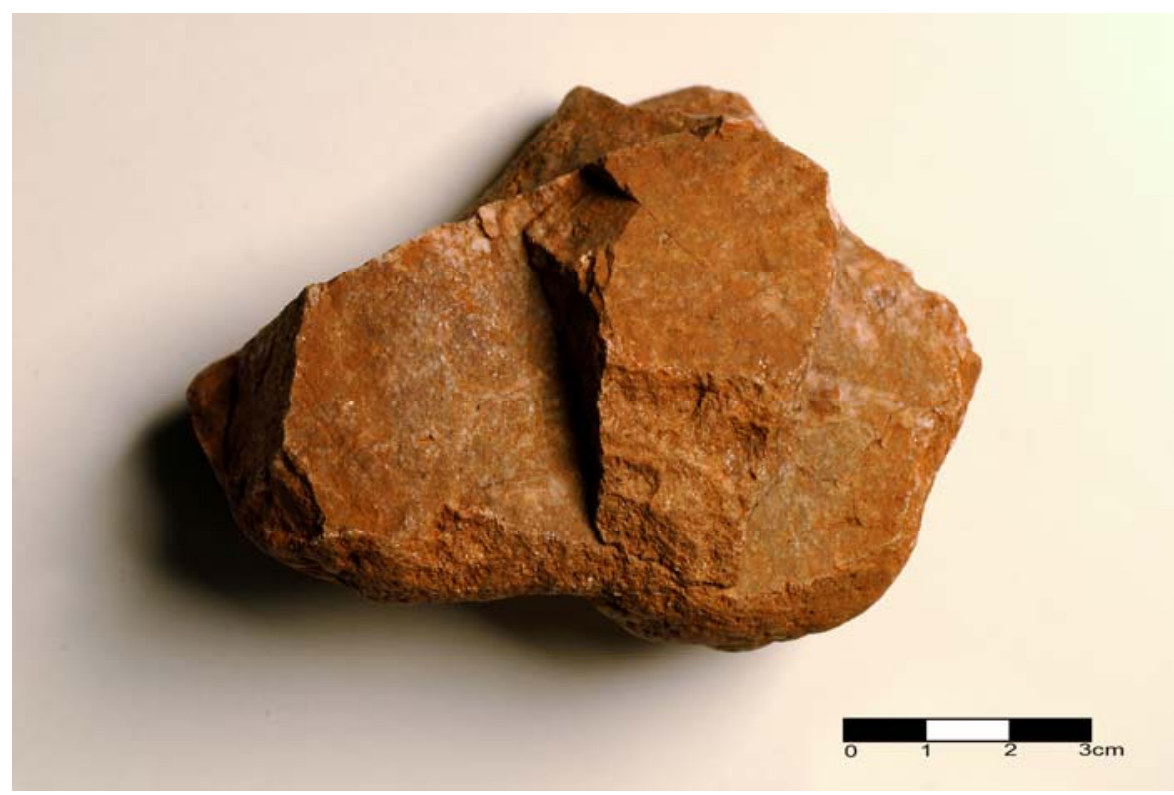

Foto: Souza,2008

\subsection{Análise tecnológica da indústria lítica do sítio Menezes e cadeia operatória}

A indústria lítica deste sítio foi confeccionada em três tipos de rochas: quartzo(leitoso), arenito e rocha básica. Apresenta artefatos polidos e lascados, perfazendo um total de 27 peças sendo 23 lascadas e 4 polidas (tabela 7).

Os tipos lascados encontrados foram: núcleos, blocos, estilhas, lascas; estes tipos caracterizam uma produção de natureza acidental, sendo que esta coleção não possui artefatos; os núcleos e blocos são peças preparatórias e que caracterizam um local de atividade de lascamento. Não há peças com retoque e não há lascas corticais.

É importante ressaltar que este sítio retrata pouca atividade na produção de artefatos líticos; o material utilizado no lascamento, o quartzo leitoso, apresenta uma superfície lisa e de maior precisão no ato de debitar ou talhar; apresenta quantidade representativa de artefatos em relação às peças de natureza acidental e preparatórias. A técnica utilizada foi o lascamento direto, unipolar e com percutor duro. A cadeia operatória da indústria lítica lascada do sítio Menezes se assemelha à industria lítica lascada do sítio Silva Serrote( ver pg.69.) 
Tabela 7: peças analisadas $X$ quantidade $X$ distribuição espacial

\begin{tabular}{|l|l|l|l|l|l|l|}
\hline Tipo & Material & $\begin{array}{l}\text { Freqüência } \\
\text { total das } \\
\text { peças }\end{array}$ & $\begin{array}{l}\text { Freqüência } \\
\text { Superfície }\end{array}$ & $\begin{array}{l}\text { Freqüência } \\
\text { Mancha 4 }\end{array}$ & $\begin{array}{l}\text { Freqüência } \\
\text { Afloram,A }\end{array}$ & $\begin{array}{l}\text { Freqüência } \\
\text { Trincheira } \\
4\end{array}$ \\
\hline núcleo & $\begin{array}{l}\text { Quartzo } \\
\text { leitoso }\end{array}$ & 8 & 3 & 3 & 1 & 1 \\
\hline Bloco & arenito & 1 & 1 & 0 & 0 & 0 \\
\hline estilhas & $\begin{array}{l}\text { Quartzo } \\
\text { leitoso }\end{array}$ & 9 & 7 & 0 & 1 & 1 \\
\hline lasca & $\begin{array}{l}\text { Quartzo } \\
\text { leitoso }\end{array}$ & 5 & 0 & 0 & 4 & 0 \\
\hline Total & - & 23 & 11 & 3 & 7 & 2 \\
\hline Porcentagem & & $100 \%$ & $47,82 \%$ & $13,04 \%$ & $30,43 \%$ & $17,39 \%$ \\
\hline
\end{tabular}

$\mathrm{Na}$ tabela 7 é possível observar que a matéria-prima predominante é o quartzo leitoso, a presença de peças preparatórias da coleção caracteriza pouco menos de $50 \%$ da coleção, e que a proporção da presença de estilhas é pequena em relação às peças preparatórias.

A presença de um baixo número de estilhas poderia indicar um lascamento mais preciso ou pouca atividade de lascamento, ou seja, redução das atividades de caça.

Artefatos polidos

Quanto ao material polido, foram encontrados quatro tipos: mão-de-pilão, lâmina de machado, seixo fragmentado e almofariz.

O polimento da pedra representou uma nova etapa de aprendizado, impulsionada pelo surgimento de novas atividades econômicas que coexistiam com as antigas; os objetos lascados desenvolvidos para a prática da caça não eram funcionais para as atividades agrícolas. Neste contexto o homem desenvolveu novas técnicas de trabalho com a rocha para atender às novas necessidades de atividade social(agrícola).

Segundo Morais \& Pallestrini(1982, pg 62) a incorporação das técnicas de polimento foi gradual e o uso de utensílios polidos ocorreu concomitantemente à manipulação da argila para a confecção da cerâmica.

Estes autores descrevem o processo de polimento:o polimento é geralmente obtido através da abrasão ou desgaste com areia úmida. Pode ser efetuado sobre uma pedra, 
pousada no solo ou às vezes o próprio solo rochoso é utilizado; as depressões resultantes do polimento se formam pouco a pouco na superfície.Os gumes são executados do mesmo modo, mas eles deixam sobre as rochas depressões alongadas.

\section{Tabela 8: Lítico polido}

\begin{tabular}{|l|l|l|l|l|}
\hline Tipologia & Material & Localização & Freqüência & $\begin{array}{l}\text { Marcas de } \\
\text { uso }\end{array}$ \\
\hline Mão-de-pilão & Rocha básica & Superfície & 1 & sim \\
\hline Lâmina de machado & Rocha básica & Superfície & 1 & sim \\
\hline Seixo fragmentado & Rocha básica & Superfície & 1 & não \\
\hline Almofariz & Pedra sabão & Superfície & 1 & sim \\
\hline Total & - & - & 4 & - \\
\hline
\end{tabular}

Todos os artefatos polidos coletados no sítio Menezes supracitados na tabela 8 foram encontrados na superfície, provavelmente devido à aragem realizada no sítio previamente ao período de escavação (também encontram-se fragmentados).

A lâmina de machado, a mão-de-pilão e o almofariz apresentam marcas de uso, corroborando desta forma a indicação de atividades relacionadas à agricultura.

\section{Definições técnicas dos artefatos encontrados (Souza, A.M, 1997)}

Lâmina de machado polida: usada para cortar, fender, retalhar um animal ou escavar o solo para extrair raízes; existem alguns tipos com gargalo ou com pescoço para melhor encabamento;alguns podem ser utilizados como cunhas .

Mão-de-pilão: o trabalho de esmagamento se efetua por movimentos circulares e laterais e por uma seqüência de pressões e pequenas percussões entre as quais as pressões são mais importantes; tritura grãos e minerais com sua extremidade distal.

Almofariz:recipiente de pedra escavado por picoteamento, algumas vezes polido ;parte complementar de uma mão de pilão.A matéria a ser trabalhada era colocada e esmagada por percussão. 


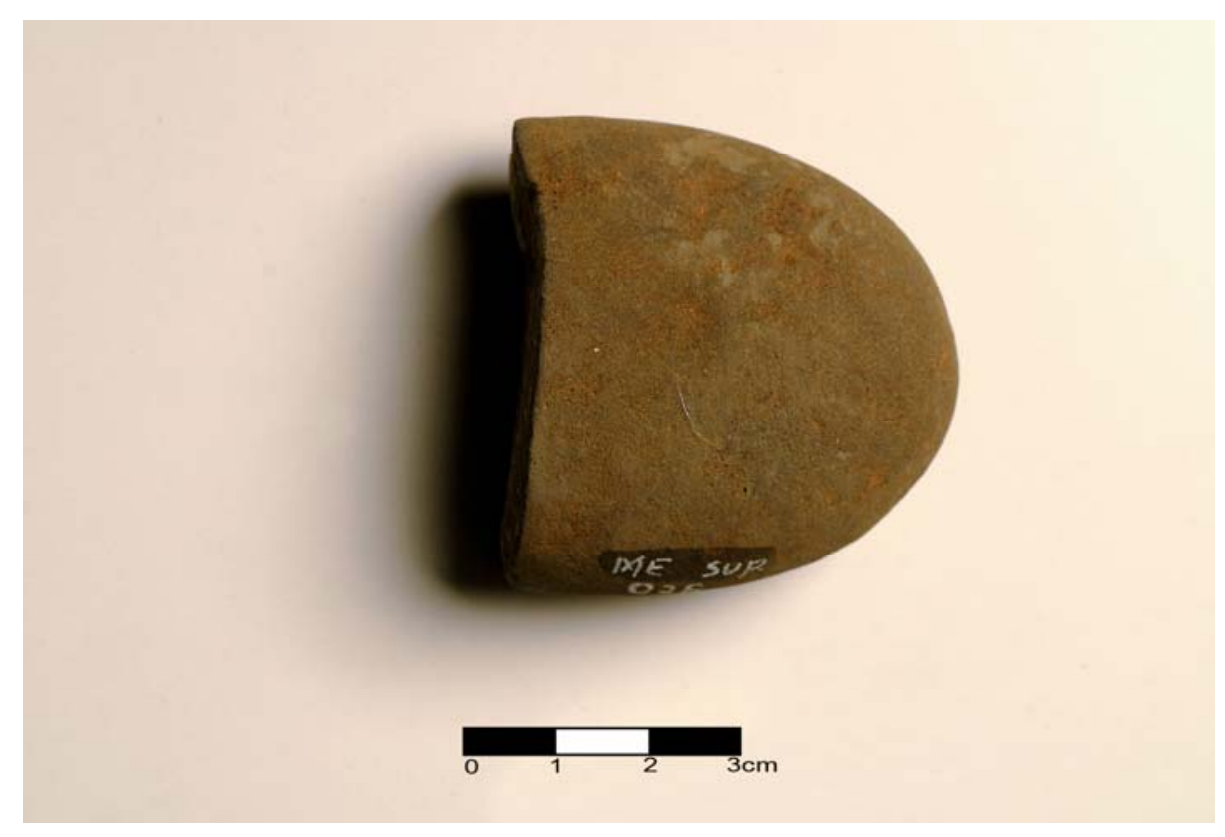

Foto, Souza, 2008.

Foto 24: Machado Fragmentado - rocha básica

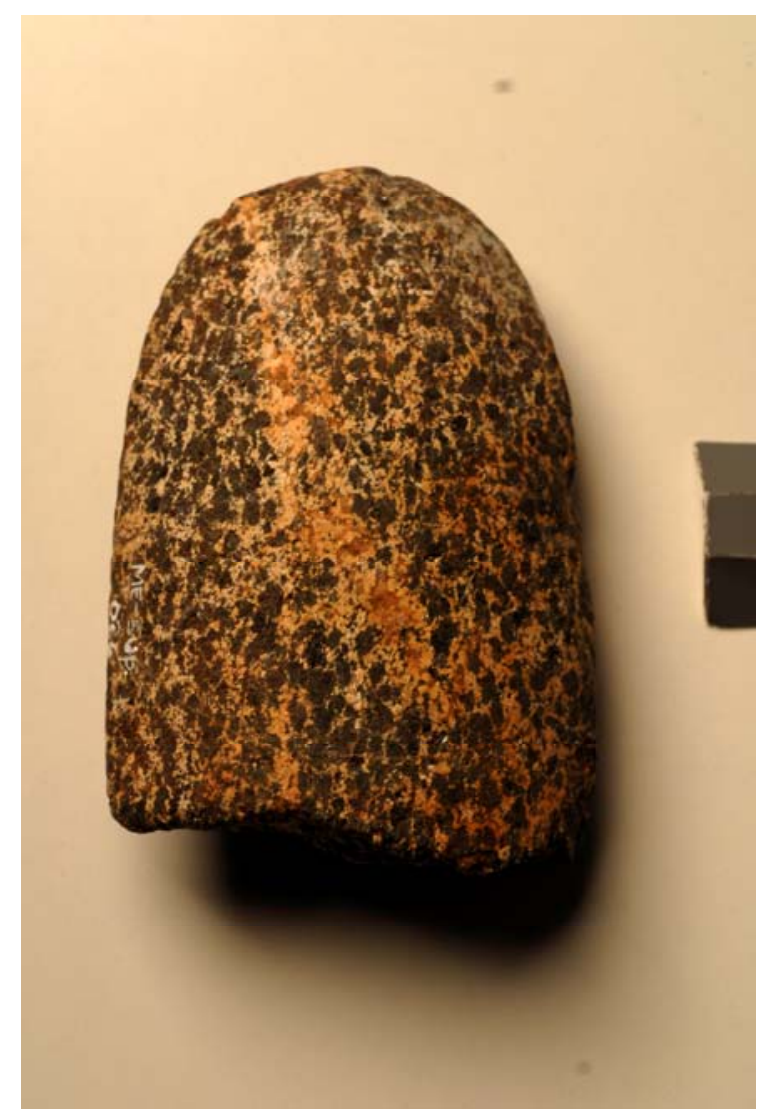

Foto: Souza, 2008.

Foto 25: Mão de Pilão Fragmentada 


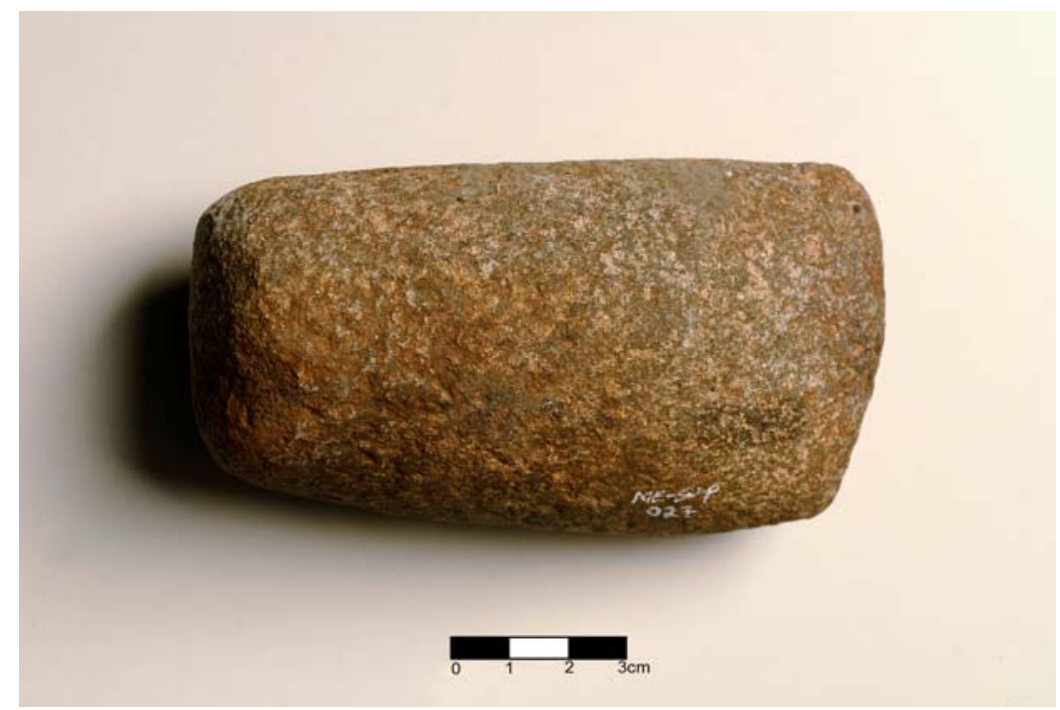

Foto: Souza, 2008.

Foto 26: Lasca em quartzo leitoso

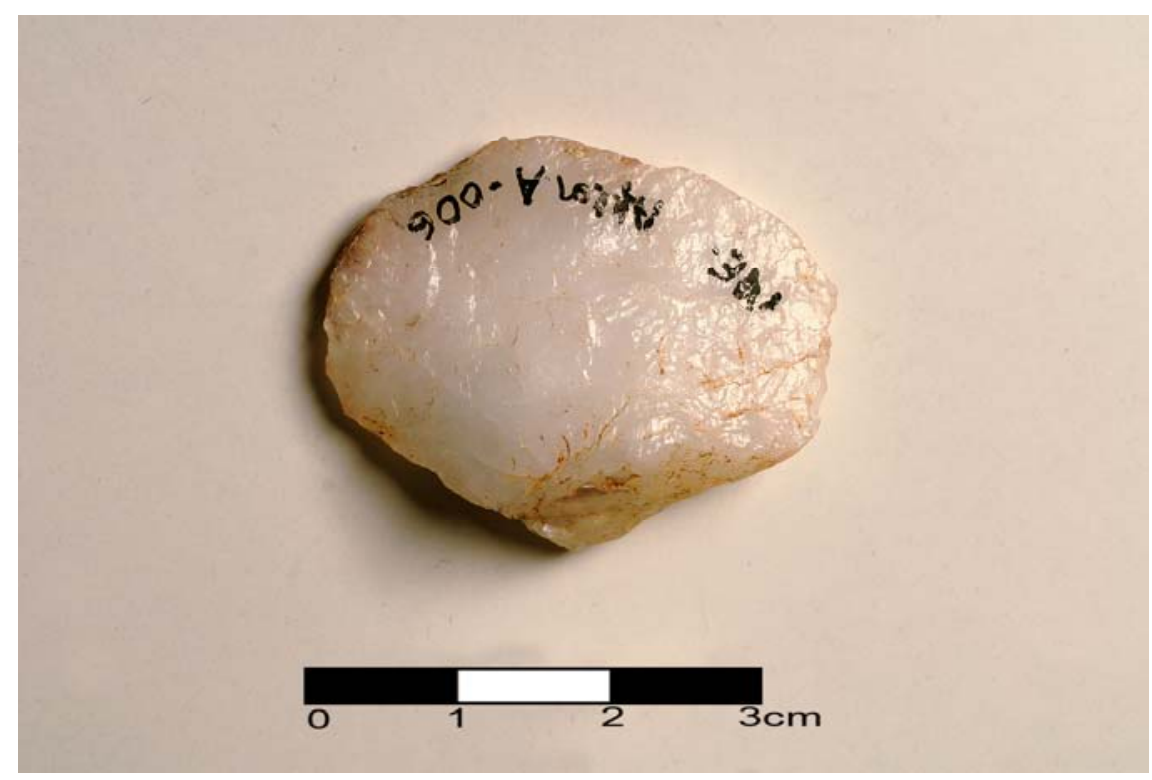

Foto: Souza, 2008.

Foto 27: Núcleo em quartzo leitoso 


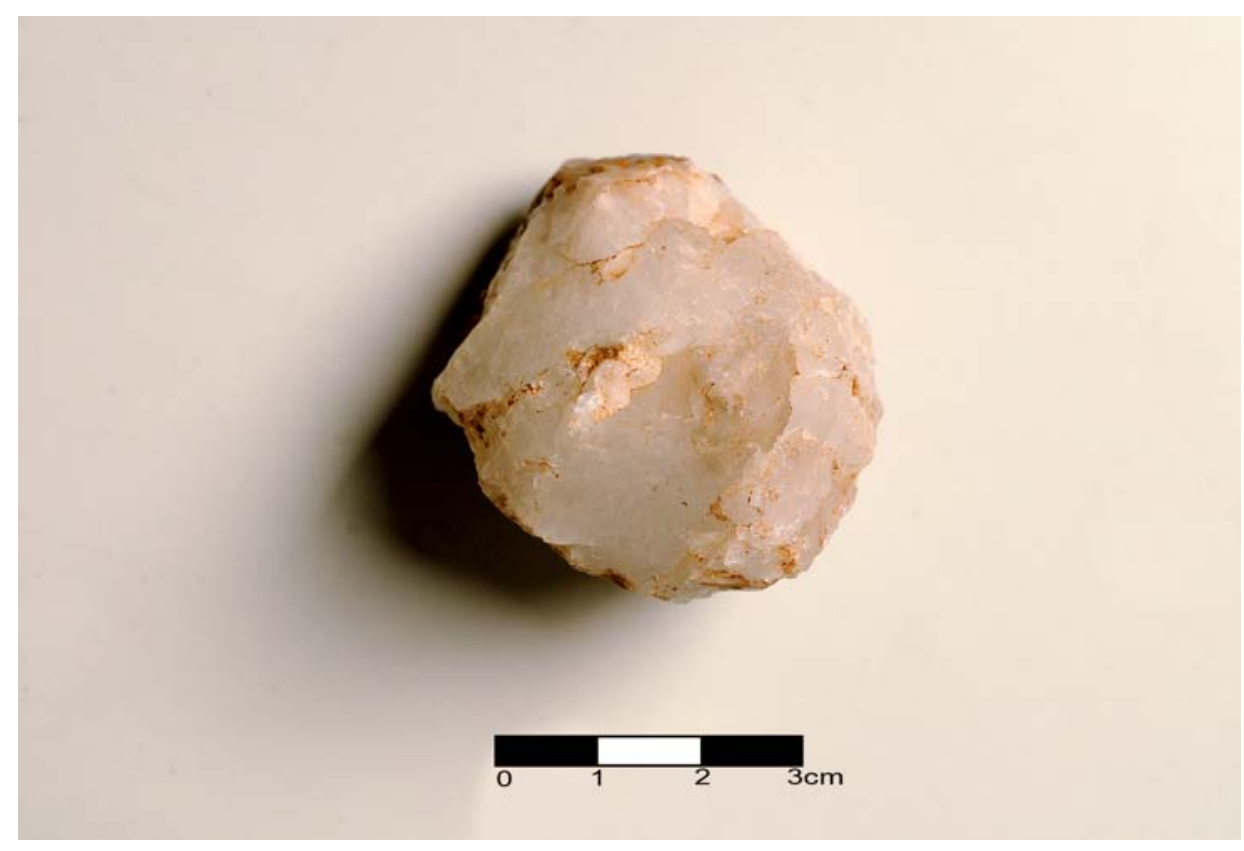

Foto: Souza, 2008.

Foto 28: Bloco em arenito

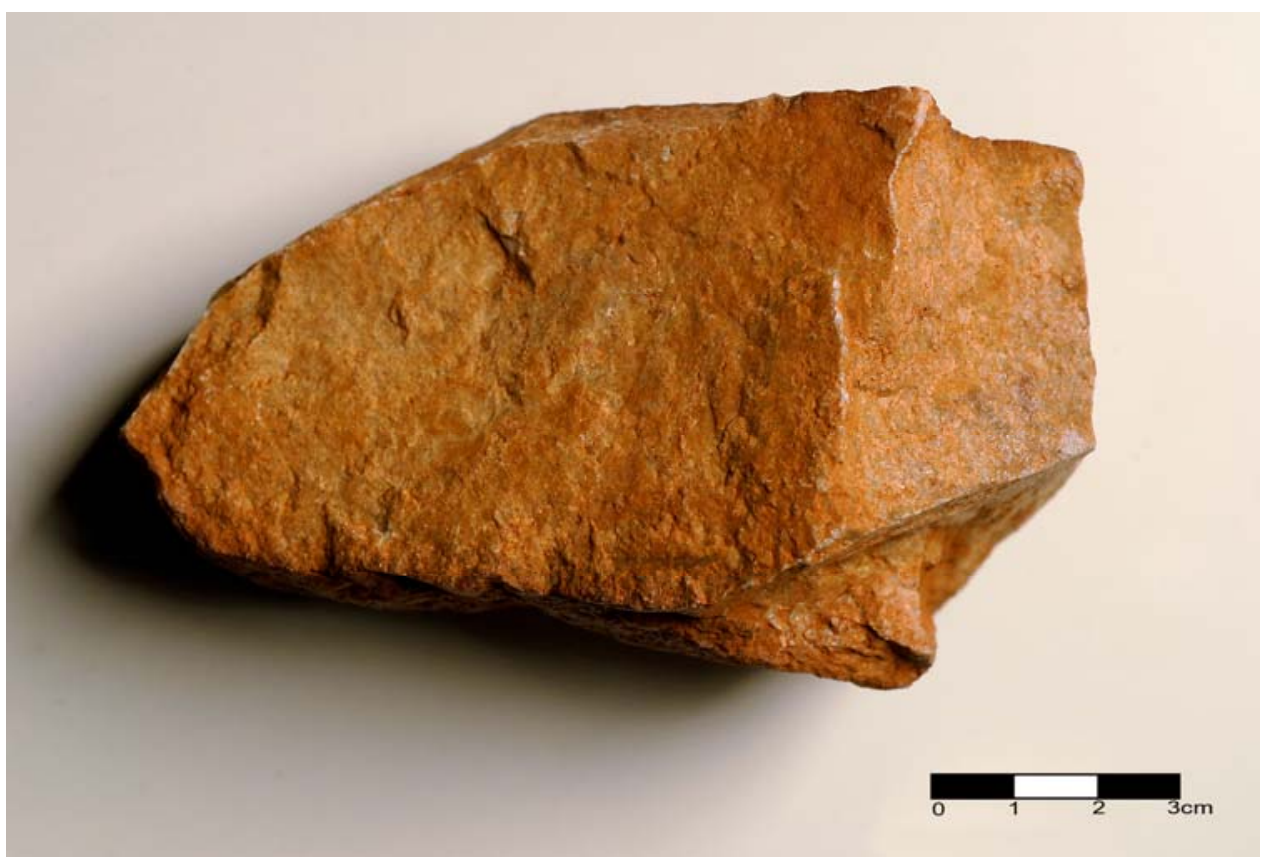

Foto: Souza, 2008.

Foto 29: Núcleo em arenito 


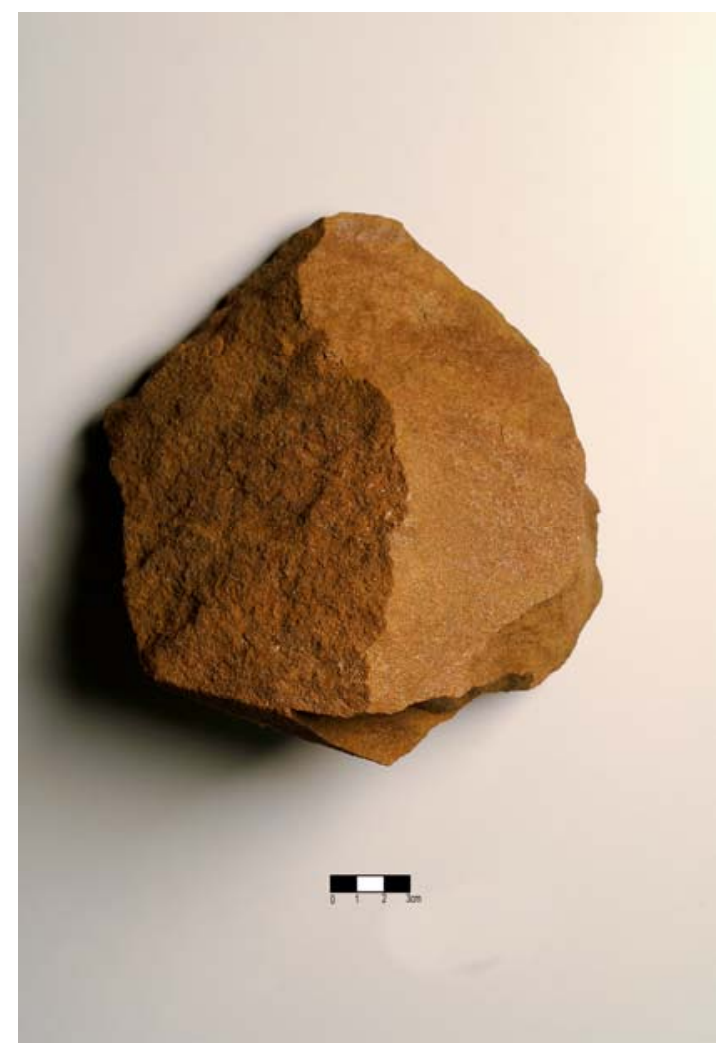

Foto: Souza, 2008.

Foto 30: Núcleo em quartzo leitoso

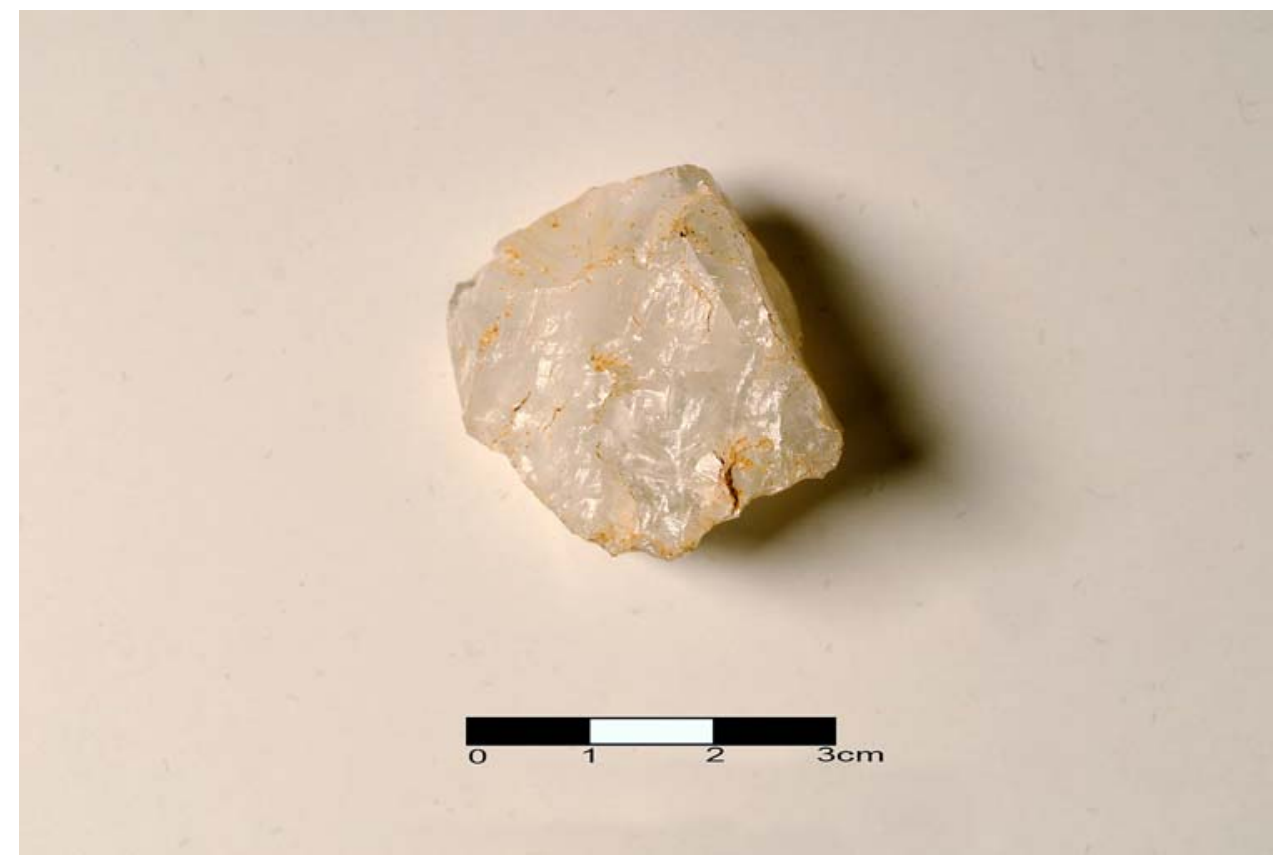

Foto: Souza, 2008.

Foto 31: Estilhas em quartzo 


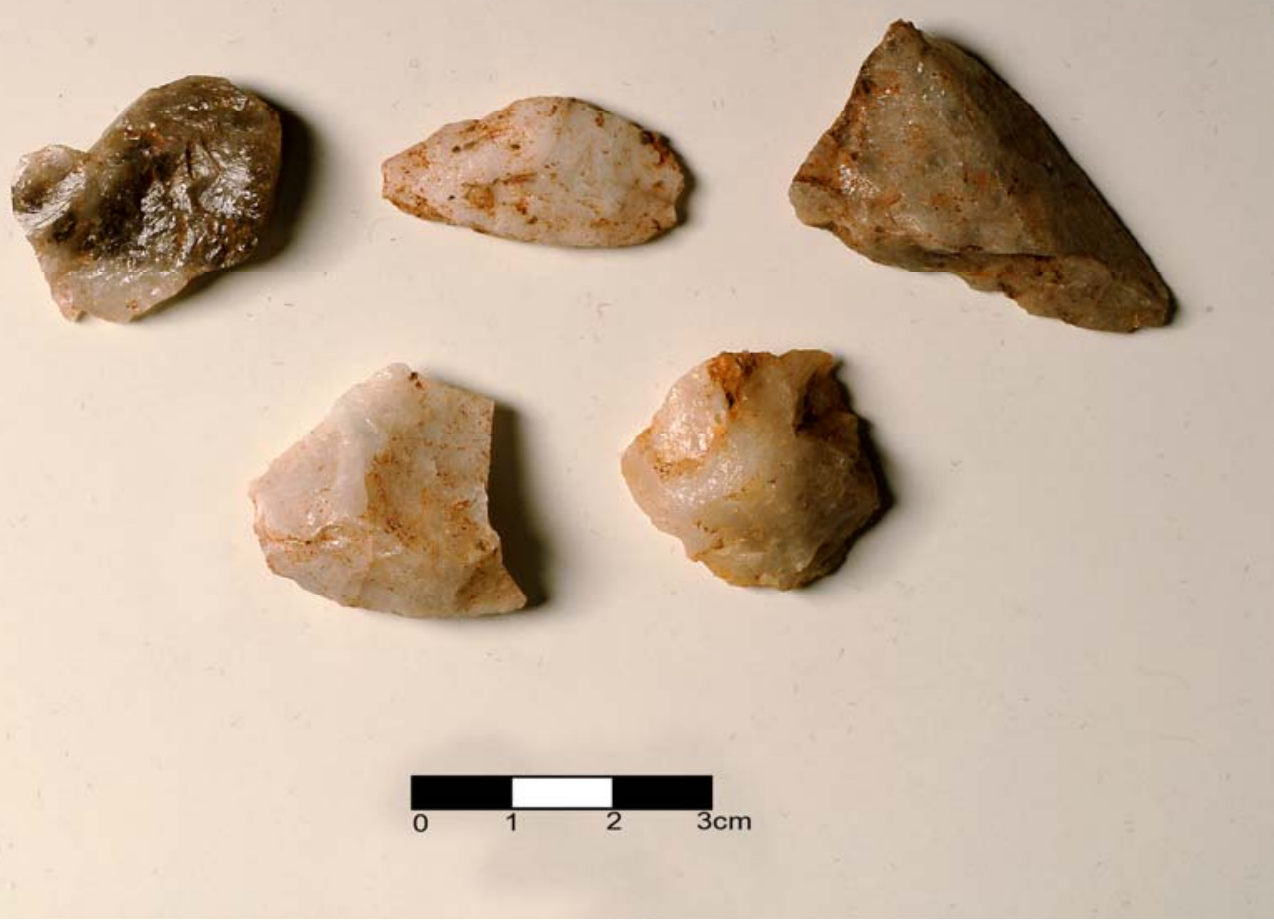

Foto: Souza, 2008.

Foto 32: núcleos em arenito e quartzo

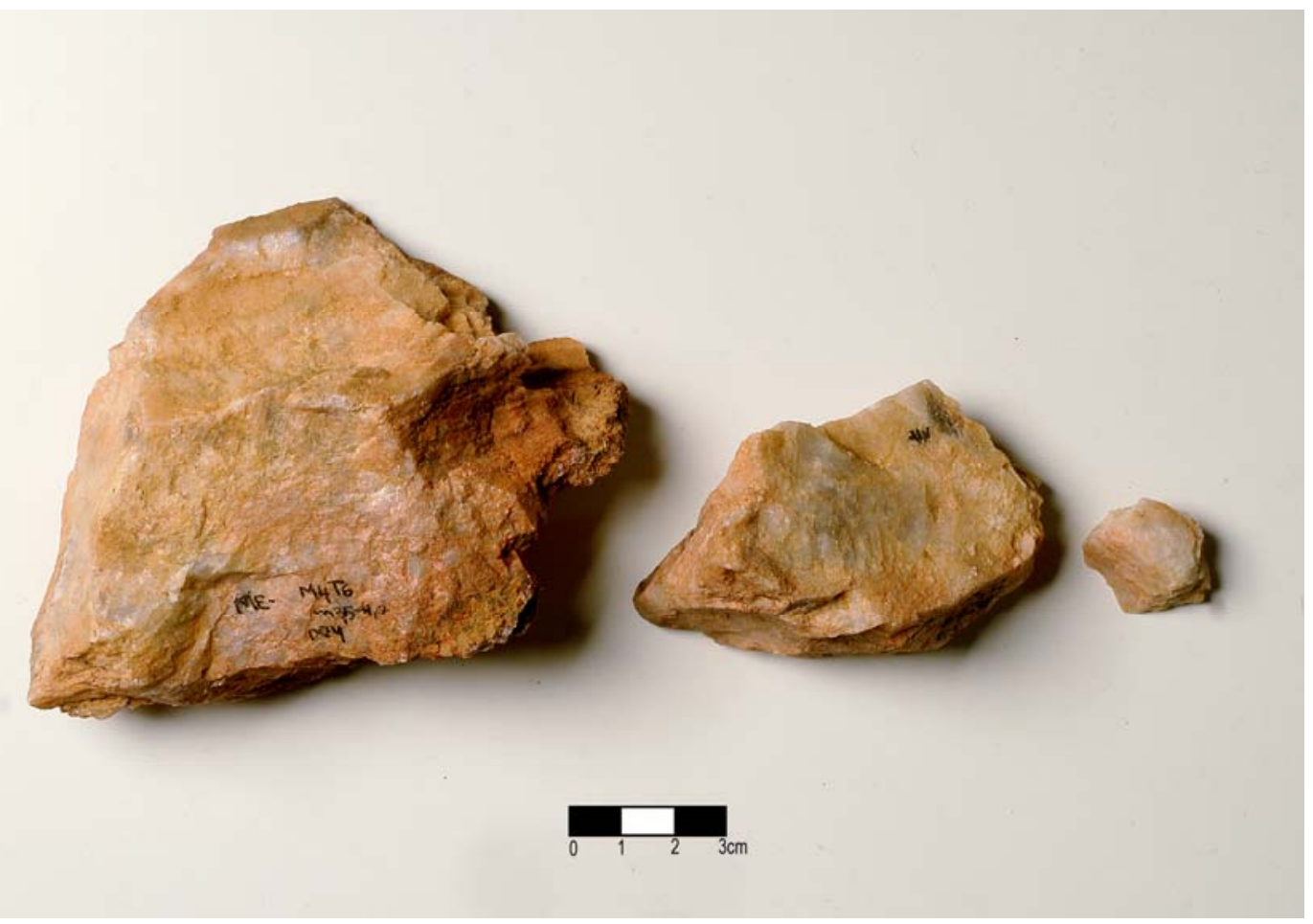

Foto: Souza, 2008. 
Tabela 9 - O Uso social dos elementos da coleção do sítio Menezes e a cadeia operatória

\begin{tabular}{|l|l|}
\hline Uso Social & Artefatolobjeto \\
\hline Descascar & Lasca com retoque \\
\hline Resíduos de atividade de lascamento & Estilhas/Núcleos \\
\hline Matriz de retirada para atividade de lascamento & Blocos \\
\hline Triturar sementes e grãos & Mão-de-pilão \\
\hline Recipiente para triturar sementes e grãos & Almofariz \\
\hline Desmatamento & Lâmina de machado \\
\hline
\end{tabular}

A indústria lítica do sítio Menezes é composta de artefatos que caracterizam uma economia baseada numa agricultura incipiente.

Dentre os artefatos lascados, podemos destacar os núcleos e os blocos, que são peças de natureza preparatória; a matriz de lascamentos(bloco), e os núcleos a peça esgotada, ou seja, que não apresenta mais superfícies angulosas para o lascamento. As lascas eram utilizadas para descascar frutos. $O$ número de estilhas, peças acidentais ou residuais indicam baixa atividade de lascamento ou aperfeiçoamento da técnica. No entanto, estas peças indicam a coexistência da técnica de lascamento com a técnica do polimento/ picoteamento.

Dentre os artefatos polidos, pode-se destacar a lâmina de machado, utilizada para derrubar a mata. A mão-de-pilão tem como função o trituramento de grãos e sementes e o almofariz é o recipiente para esta atividade. 


\section{Capítulo 4- Análise tecnológica da indústria cerâmica do sítio Menezes}

\subsection{Análise tecnotipológica da produção cerâmica}

A Análise tecnotipológica da cerâmica foi feita de acordo com as premissas apontadas pelos seguintes autores:Alves (1982,1988,1994,1997), Alves \& Girardi(1989). Cremonte(1991), Goulart (2004), Mirambell \& Lorenzo(1983), Rice(1992), Shepard(1963), Seronie-Vivien (1975).

Os critérios de análise são: formas da cerâmica (base, bojo e borda), acabamento, queima, têmpero/antiplástico, pasta, minerais e outros (Alves, 1982,1988,1994,1997a, 1997b;Goulart,2004).

A ficha de análise utilizada foi a de Alves (1988) e Goulart (2004). A triagem teve início com a separação dos fragmentos por indicação morfológica: borda, base, bojo e fragmentos sem indicação morfológica. Foi realizada a classificação dos tipos de borda, espessura da parede, técnica de montagem, acabamento, alisamento, polimento reconstituição de algumas bordas com o ábaco, e a análise das lâminas petrográficas.

Dados empíricos

Os elementos cerâmicos do sítio Menezes foram coletados em um único estrato arqueológico: o lito-cerâmico (1939 elementos). A ocorrência de fragmentos deslocados para a superfície foi devido ao arado do solo para o plantio.

A cerâmica do sítio Menezes é predominantemente lisa, sem decoração plástica, engobo e pintura. A técnica de montagem aplicada foi a acordelada e a técnica de acabamento empregada foi $o$ alisamento.

No preparo da pasta para a montagem do vasilhame cerâmico, não houve uma seleção minuciosa dos grãos(minerais); neste sentido, predominou o emprego de grãos grossos, fato que sugere uma escolha cultural (preferência) pelo uso constante de grãos de quartzo grandes e grossos.

Há presença de rodelas de fuso perfuradas e uma base convexa de vaso duplo.

Um fragmento de cuscuzeiro também foi encontrado, e que indica cultivo e cozimento de milho (por analogia etnográfica de grupos Macro-Jê( Brochado,1977).

As decapagens executadas por níveis naturais realizadas em quatro manchas escuras evidenciaram a seguinte configuração:

Zona arada (Mancha 1, 2 e 4)- presença de cerâmica muito fragmentada 
Zona intacta-(Mancha 3 e perfil 1 )- presença de cerâmica pouco fragmentada.

No total, foram analisados 1939 elementos cerâmicos. Segue a classificação por indicação morfológica:

- Bordas: foram coletadas 71 bordas, em sua maioria diretas(com presença de algumas e com espessura de parede que varia de 0,5 a 1,6 cm; 9 fragmentos foram encontrados na mancha 1; 6 elementos na mancha 2; 8 na mancha 3; 10 na mancha 4; 3 na trincheira 1; 2 fragmentos na trincheira 2; 6 na trincheira 3; 1 na trincheira 6; 19 no perfil 1 e 4 na superfície da zona arada.

- Base: foram coletadas 6 bases. Foram encontrados 2 elementos na mancha 2, 1 na mancha 4; 1 na trincheira 6; 1 no Perfil 1 e uma na superfície da zona arada.

- Bojo: Foram coletados 88 bojos; 2 foram encontrados na mancha 1; 25 na mancha 3; 14 na mancha 4;14 na trincheira $1 ; 3$ na trincheira 2;13 na trincheira 3; 6 na trincheira $6 ; 12$ no perfil 1 .

- Elementos sem indicação morfológica: foram coletados 1774 no total. 169 foram retirados da mancha 1; 109 da mancha 2; 137 da mancha 3 ;162 da mancha 4; 138 na trincheira 1; 137 na trincheira 2; 25 na trincheira 3; 5 na trincheira 4; 140 na trincheira 6; 53 no perfil 1; 328 no perfil 1 trincheira 1 e 373 na superfície da zona arada.

- Fusos: foram coletados na superfície.

Tabela 10: Tabela quantitativa da cerâmica- Sítio Menezes

\begin{tabular}{|l|l|l|}
\hline Elemento cerâmico & Quantidade & Porcentagem \\
\hline Bojo & 88 & $4,53 \%$ \\
\hline Base & 6 & $0,30 \%$ \\
\hline Borda & 71 & $3,68 \%$ \\
\hline $\begin{array}{l}\text { Fragmentos sem indicação } \\
\text { morfológica }\end{array}$ & 1774 & $91,49 \%$ \\
\hline Total & 1939 & $100 \%$ \\
\hline
\end{tabular}


A tabela 10 apresenta o intenso número de fragmentos sem indicação morfológica devido à aragem do solo; este número também pode representar um número significativo de peças que compunham os bojos e desta forma, o volume dos recipientes.

Tabela 11: Tabela Quantitativa de Elementos Morfológicos X Localização

\begin{tabular}{|l|l|l|l|l|l|l|}
\hline Localização & Bojos & Bordas & Bases & $\begin{array}{l}\text { Elementos } \\
\text { sem } \\
\text { indicação } \\
\text { morfológica }\end{array}$ & Total & Porcentagem \\
\hline Mancha 1 & 2 & 9 & 0 & 169 & 180 & $9,28 \%$ \\
\hline Mancha 2 & 0 & 6 & 2 & 109 & 117 & $6,03 \%$ \\
\hline Mancha 3 & 25 & 8 & 0 & 137 & 170 & $8,77 \%$ \\
\hline Mancha 4 & 14 & 10 & 1 & 162 & 190 & $9,79 \%$ \\
\hline Trincheira 1 & 14 & 3 & 0 & 138 & 155 & $7,99 \%$ \\
\hline Trincheira 2 & 3 & 2 & 0 & 137 & 142 & $7,23 \%$ \\
\hline Trincheira 3 & 13 & 6 & 0 & 25 & 44 & $2,26 \%$ \\
\hline Trincheira 4 & 0 & 0 & 0 & 5 & 5 & $0,25 \%$ \\
\hline Trincheira 6 & 6 & 1 & 1 & 140 & 150 & $7,73 \%$ \\
\hline Perfil 1 & 12 & 19 & 1 & 53 & 85 & $4,38 \%$ \\
\hline $\begin{array}{l}\text { Perfil 1 1 } \\
\text { Trincheira 1 }\end{array}$ & 0 & 0 & 0 & 328 & 328 & $16,91 \%$ \\
\hline $\begin{array}{l}\text { Superfície/Zona } \\
\text { Arada }\end{array}$ & 0 & 4 & 1 & 430 & 373 & $19,23 \%$ \\
\hline Total & 88 & 71 & 6 & 1774 & 1939 & $100 \%$ \\
\hline
\end{tabular}

A tabela 11 indica que a Zona de concentração da cerâmica foi o P1, trincheira 1 , mancha 1 e mancha 4, assim como a proporção entre os elementos morfológicos encontrados. 


\section{Espessura da parede:}

Todos os fragmentos da coleção foram mensurados: bordas, bojos, bases e fragmentos sem indicação morfológica. A espessura da parede está relacionada com o emprego social do vasilhame.Segue tabela:

Tabela 12 - Espessura da parede

\begin{tabular}{|l|l|l|l|l|}
\hline Morfologia & Bordas $/ \%$ & Bojos/ \% & Bases/ \% & Fragmentos/ \% \\
\hline Muito Fina- até 6mm & $15-21,71 \%$ & $10-11,36 \%$ & $1-16 \%$ & $204-11,50 \%$ \\
\hline Fina- entre 7 e 9 mm & $24-33,80 \%$ & $33-37,5 \%$ & $3-50 \%$ & $679-38,27 \%$ \\
\hline Média- 10 e 14 mm & $20-29 \%$ & $41-46,59 \%$ & $2-44 \%$ & $556-31,34 \%$ \\
\hline Grossa-15 e 20 mm & $11-15,49 \%$ & $4-4,50 \%$ & $0-0 \%$ & $335-18,89 \%$ \\
\hline $\begin{array}{l}\text { Muito Grossa-acima } \\
20 \mathrm{~mm}\end{array}$ & $0-0 \%$ & $0-0 \%$ & $0-0 \%$ & $0-0 \%$ \\
\hline Total & $\mathbf{7 1}$ & $\mathbf{8 8}$ & $\mathbf{6}$ & $\mathbf{1 7 7 4}$ \\
\hline
\end{tabular}

A tabela 12 descreve os dados relativos à espessura de parede. Os critérios estabelecidos foram: muito fina, até $6 \mathrm{~mm}$, fina, entre 7 e $9 \mathrm{~mm}$, média, entre 10 e $14 \mathrm{~mm}$, grossa, entre 15 e $20 \mathrm{~mm}$ e muito grossa, acima de $20 \mathrm{~mm}$. As espessuras de maior freqüência foram as de morfologia fina e média, fato que pode representar que a maioria dos fragmentos sem indicação morfológica constituam o bojo, parte de maior largura do vasilhame. Estes dados associados às reconstituições cerâmicas pranchas 1 a 8 , revelam vasilhames de 4,41 L até 204,04L.(urna silo para armazenamento de grãos).

Tabela 13 : Formas das Bordas:

\begin{tabular}{|l|l|l|l|}
\hline Bordas & Lábios & Quantidade & Frequência \\
\hline Direta & arredondado & 50 & $70,42 \%$ \\
\hline Inclinada interna & arredondado & 5 & $7,04 \%$ \\
\hline Entrovertida & arredondado & 2 & $2,81 \%$ \\
\hline Expandida & arredondado & 2 & $2,81 \%$ \\
\hline Direta & apontado & 11 & $16 \%$ \\
\hline Total & - & $\mathbf{7 1}$ & $\mathbf{1 0 0 \%}$ \\
\hline
\end{tabular}


De acordo com a tabela 13, o tipo mais freqüente encontrado é a borda direta e arrendada, compondo 50 \% da coleção; o segundo tipo de maior freqüência é a borda direta e apontada com $16 \%$ da frequencia, seguida do tipo inclinada interna $7,04 \%$, entrovertida e arredondada $2,81 \%$ e expandida arredondada $2,81 \%$.

Tabela 14: Análise das bases

\begin{tabular}{|l|l|l|}
\hline Tipo de bases & Grau & Freqüência \\
\hline Convexa & $10^{\circ}-1$ & 2 \\
& $15^{\circ}-1$ & \\
\hline Plana & $5^{\circ}-3$ & 4 \\
& $10^{\circ}-1$ & \\
\hline Total & 6 & 6 \\
\hline
\end{tabular}

A tabela 14 apresenta os tipos de bases, que contribuem para a forma do vasilhame; dentre as seis bordas encontradas, duas são convexas e quatro são planas.

Tabela 15: Análise dos bojos

\begin{tabular}{|l|l|}
\hline Bojos & Tipo Côncavo \\
\hline $10^{\circ}$ & 5 \\
\hline $15^{\circ}$ & 12 \\
\hline $20^{\circ}$ & 2 \\
\hline $25^{\circ}$ & 5 \\
\hline $30^{\circ}$ & 21 \\
\hline $35^{\circ}$ & 1 \\
\hline $40^{\circ}$ & 25 \\
\hline $45^{\circ}$ & 10 \\
\hline $75^{\circ}$ & 3 \\
\hline $80^{\circ}$ & 4 \\
\hline Total & 88 \\
\hline
\end{tabular}

A tabela 15 detalha acerca da classificação dos bojos; em um universo de 88 peças, a totalidade é côncava; 5 peças apresentam $10^{\circ}, 12$ peças apresentam $15^{\circ} ; 2$ peças possuem 
$20^{\circ}, 5$ peças apresentam $25^{\circ}, 21$ peças com $30^{\circ} ; 1$ peça $35^{\circ} ; 25$ peças possuem $40^{\circ}, 10$ peças apresentam $45^{\circ}, 3$ peças possuem $75^{\circ}$ e fragmentos apresentam ângulo de $80^{\circ}$.

\subsection{A cadeia operatória da cerâmica do sítio Menezes}

A cadeia operatória tem início a partir da busca e da obtenção da matéria-prima; a escolha da matéria-prima está relacionada com o uso social da futura peça, ou seja, com os atributos finais desejáveis pelo artesão, que irá escolher a argila de acordo com as características que ela provavelmente apresentará ao final da queima. (como por exemplo, se a artesã deseja uma peça mais leve, ou mais resistente, de acordo com a necessidade de uso). O rio Quebra-anzol e o rio Galheiro são os principais rios da cidade de Guimarânia e oferecem fontes argilosas às suas margens e cercanias.

\section{Técnica de manufatura}

No sítio Menezes, a preferência é pela pasta com baixa seletividade de grãos, mais densa e que produz peças mais espessas e resistentes.(Alves 1982,1983/84, 1988, 1991,1992,1994,1997 a,1997 b,1999b).O sítio Menezes, conforme constatado possui várias fontes argilosas no entorno dos córregos que atravessam o sítio.

A segunda etapa da cadeia operatória é a técnica de processamento da pasta. Nesta etapa, podem ser adicionados à argila, elementos que adequem a plasticidade da peça às necessidades da artesã no ato da modelagem(tempero ou antiplástico). As fontes argilosas encontradas no sítio Menezes na prospecção de 2008, apresentam cor avermelhada e presença maciça de grãos de quartzo.

No momento em que a pasta atinge a plasticidade considerada adequada aos padrões do grupo para determinada peça, tem início a modelagem, que origina a forma e a técnica de acabamento. As técnicas de modelagem para a obtenção da forma são tradicionalmente transmitidas no grupo; nos grupos que habitavam o Brasil, a técnica de montagem mais difundida foi a acordelada, que consiste na sobreposição de roletes de argila, de diversos tamanhos e espessura, seguida do acabamento que contribui para a forma. 


\section{Acabamento de superfície}

As técnicas de acabamento, assim como todo o processo, complementam os atributos que compõem o conjunto de características desejadas para o uso social da peça. A técnica de acabamento utilizada nas peças foi o alisamento.

A técnica do alisamento geralmente era executada com seixos de rocha ou outros objetos que eliminavam as marcas dos roletes de argila. O processo é feito após a montagem do vasilhame e precede a queima. Todos os fragmentos da coleção foram alisados.

Todas as peças da coleção obtidas na investigação do Sítio Menezes não possuem decoração plástica.(Ausência de pintura, engobo,banho, brunidura).

A etapa que se segue é a queima; no Sítio Menezes a queima foi feita partir do uso da fogueira rasa, próximas e externas às habitações.

No sítio Menezes, de acordo com as formas obtidas na reconstituição dos vasos, compreende-se a preferência por argila com baixa seletividade de grãos de quartzo, pois as peças estudadas e que caracterizam a produção deste grupo, possuem formas que indicam uso social de armazenamento de grãos, pois as peças são densas e resistentes; o cuzcuzeiro, já citado neste trabalho corrobora processamento dos grãos de milho.

Foram reconstituídos oito vasilhames a partir de bordas de diversos tamanhos encontradas no sítio Menezes; todas as formas reconstituídas têm emprego social por analogia relacionados à agricultura.

\section{Tabela 16: O Uso social da cerâmica do sítio Menezes}

\begin{tabular}{|l|l|}
\hline $\begin{array}{l}\text { Fiação e tecelagem de fibra vegetal, provavelmente } \\
\text { algodão }\end{array}$ & Fusos perfurados \\
\hline Alimentação, cozimento do milho & Cuscuzeiro \\
\hline $\begin{array}{l}\text { Atividades simbólicas, pode expressar polaridade } \\
\text { entre sol e lua, noite e dia(Silva,2000) }\end{array}$ & Vasos geminados \\
\hline Armazenamento de grãos e sementes & Urnas silo \\
\hline Transporte de grãos-horticultura & Vasilhames cerâmicos de volume médio \\
\hline
\end{tabular}

A partir de alguns tipos de vasilhames cerâmicos identidicados, podemos inferir algumas atividades sociais praticadas. Os fusos perfurados caracterizam atividades relacionadas à tecelagem de fibra vegetal, provavelmente algodão. A presença dos fragmentos de cuscuzeiro caracterizam o processamento do milho para o cozimento. 
A base de vaso geminado indicaria atividade simbólica em relação à representação de polaridades, como por exemplo, sol e lua, noite e dia (Silva, 2000). As urnas silo indicam o armazenamento de grãos e sementes e os vasilhames de volume médio podem haver sido utilizados como recipiente para transporte de grãos.

Foto 33: Sítio Menezes-argila exposta pela erosão

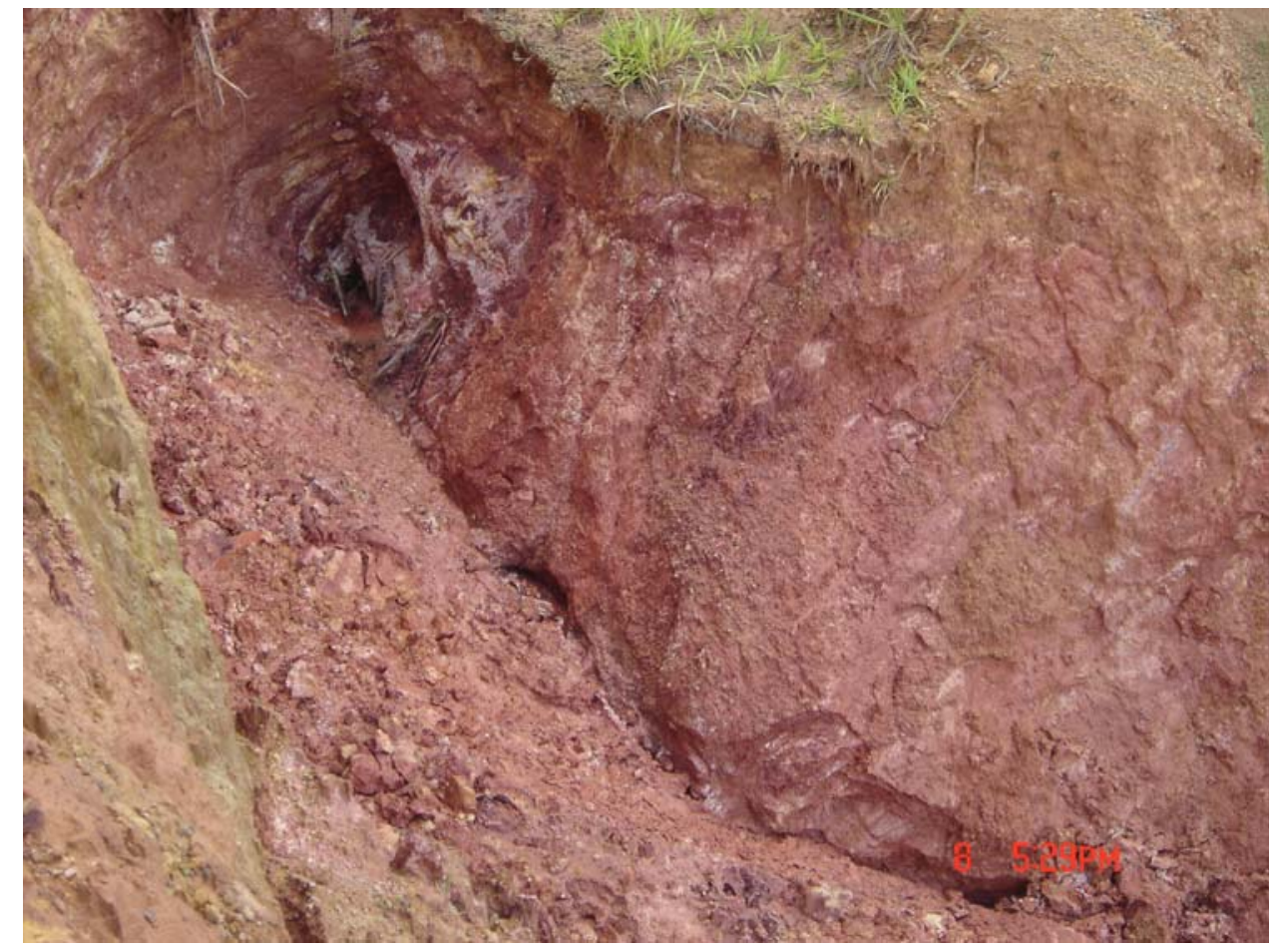

Foto: Figueiredo, 2008 
Foto 34: Sítio Menezes: fonte argilosa

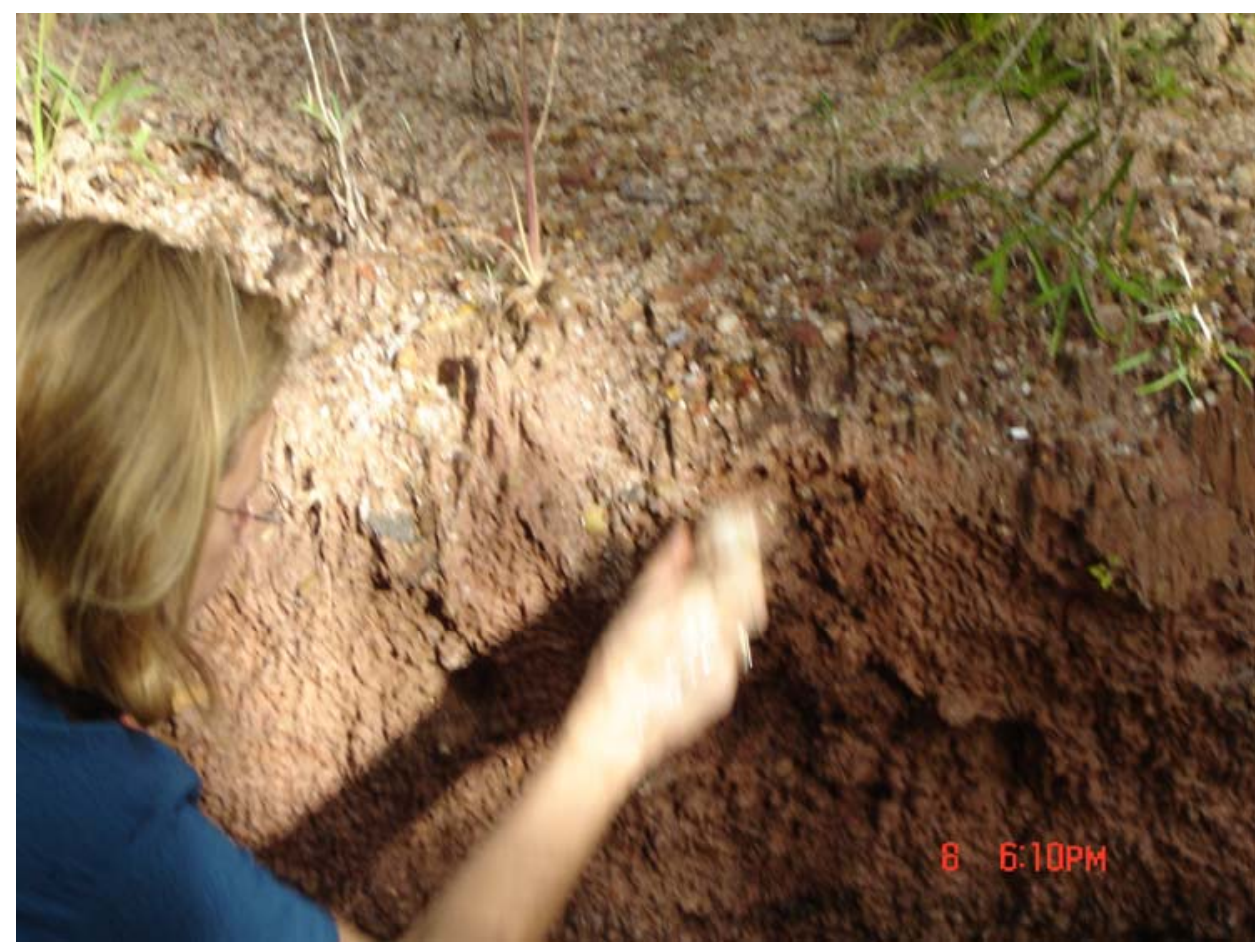

Foto: Campos Menezes, 2008.

Foto 35: Sítio Menezes- Cuscuzeiro in situ -Perdizes-MG

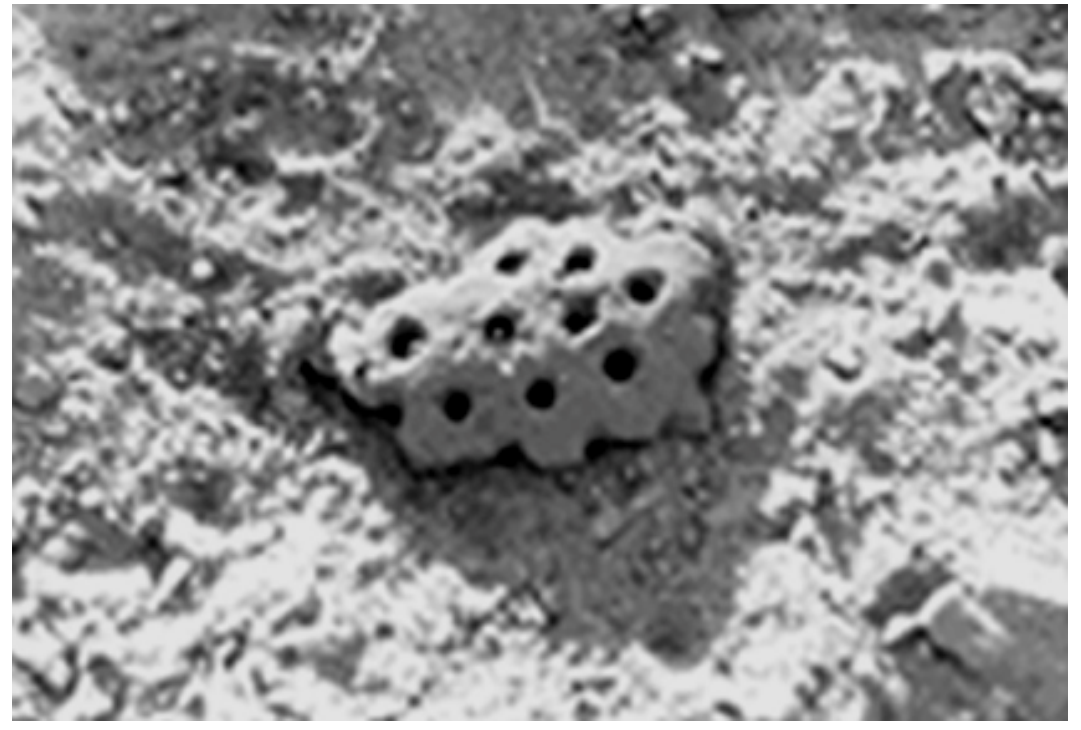

Foto: Alves, 1992. 
Foto 36: Sítio Menezes-Cuscuzeiro-Perdizes-MG

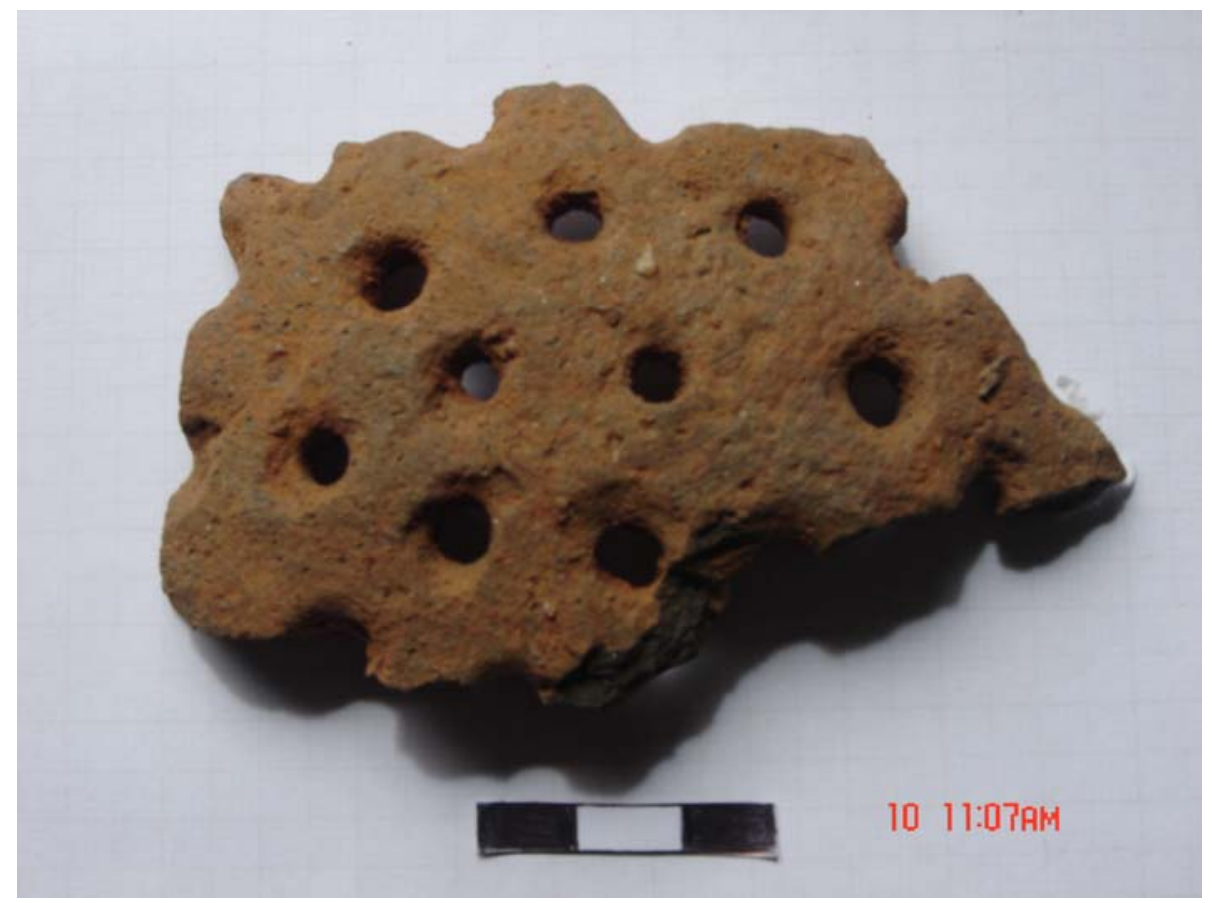

Foto:Figueiredo, 2008.

Foto 37: Sítio Menezes-Cuscuzeiro-Perdizes-MG

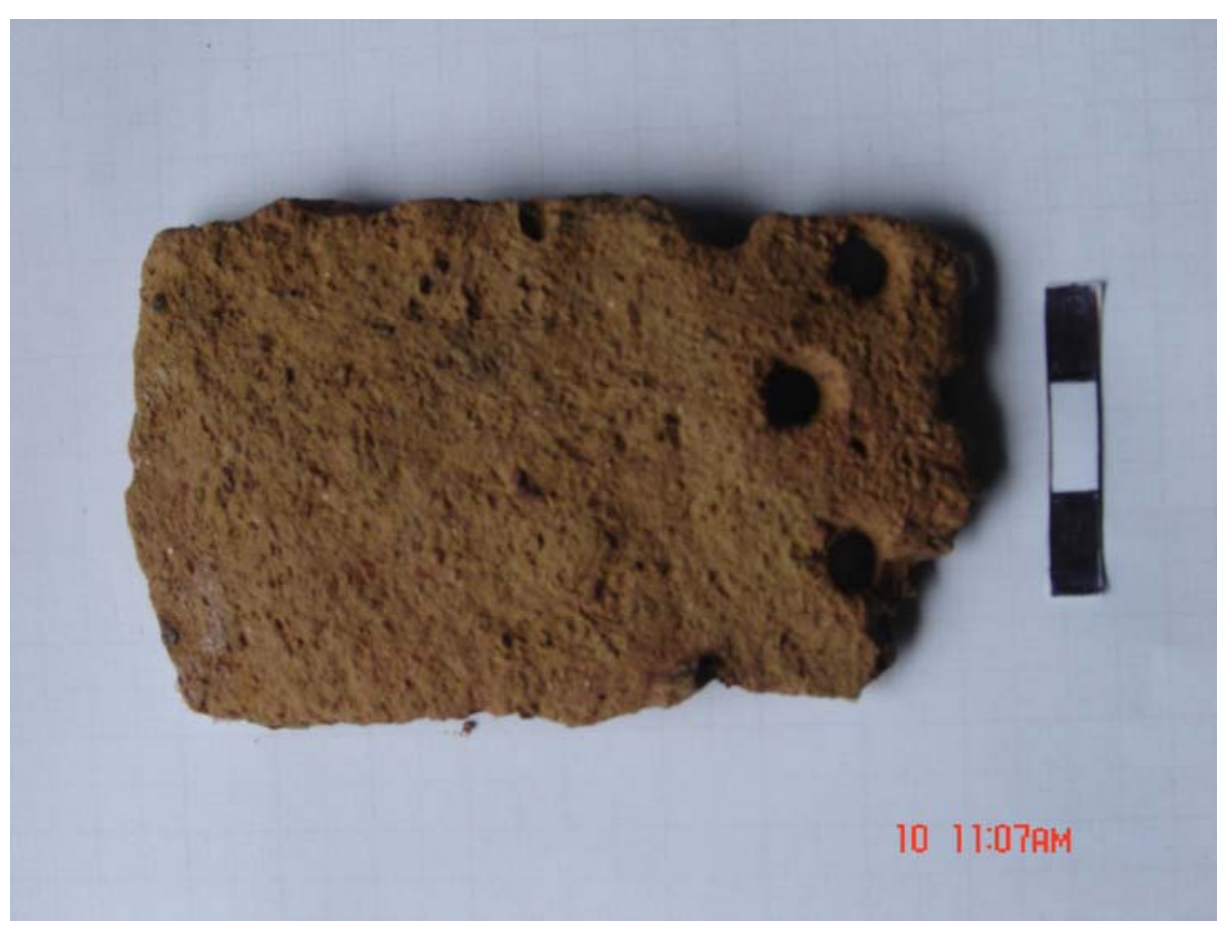

Foto:Figueiredo,2008 
Foto 38: Sítio Menezes - Fragmento de Bojo

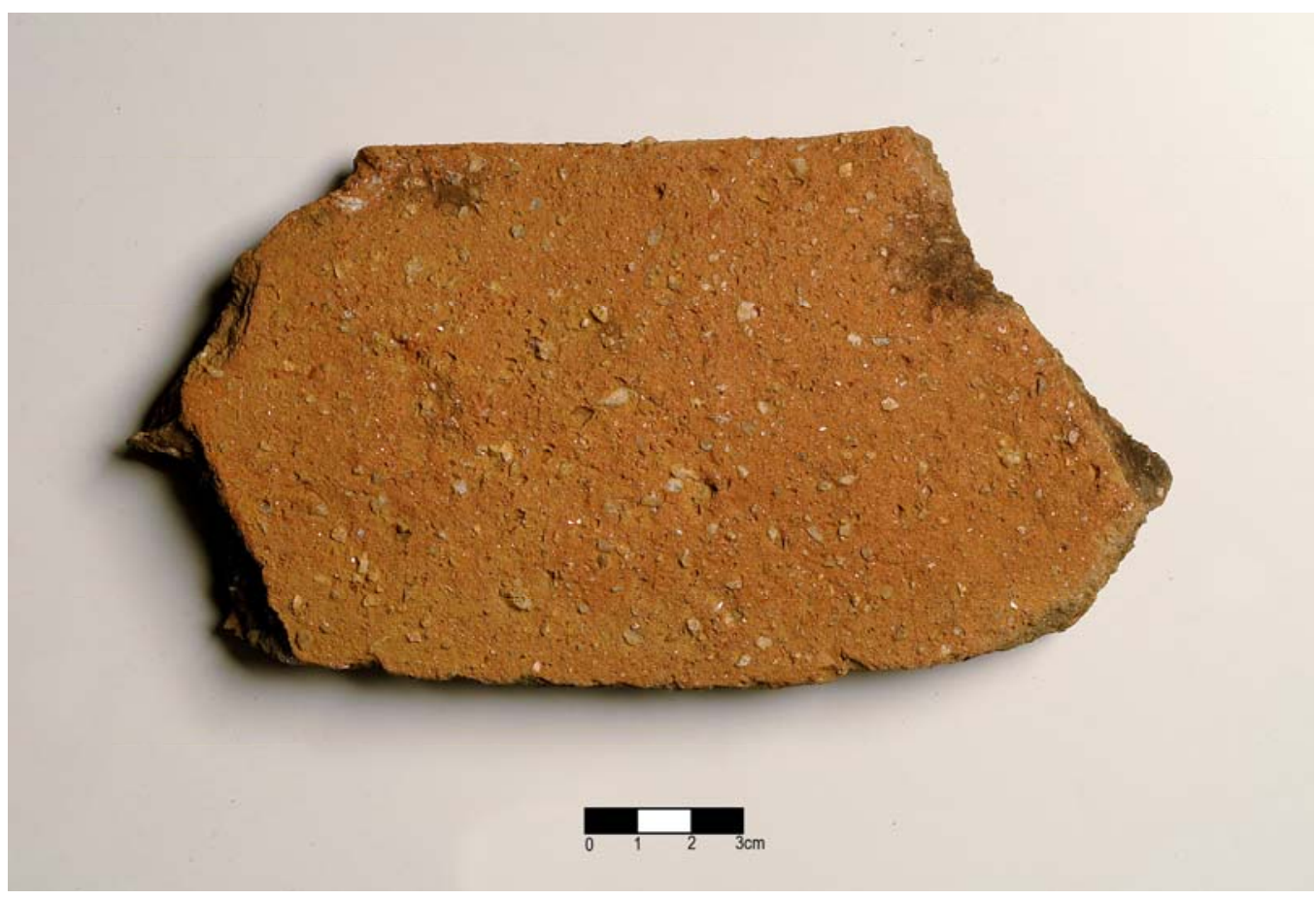

Foto:Souza, 2008

Foto 39: Sítio Menezes - Fragmento de borda

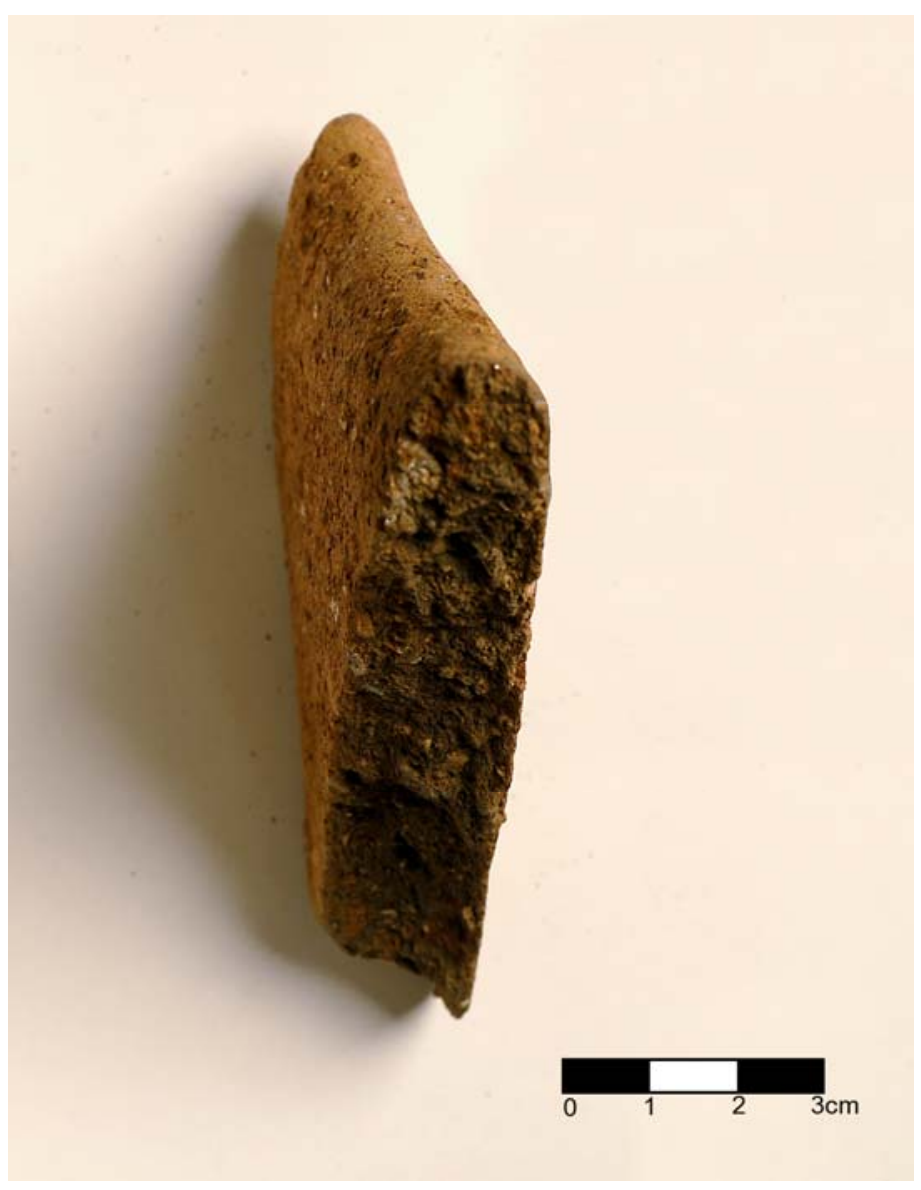

Foto: Souza, 2008. 
Foto 40: Sítio Menezes-Fragmento de bojo

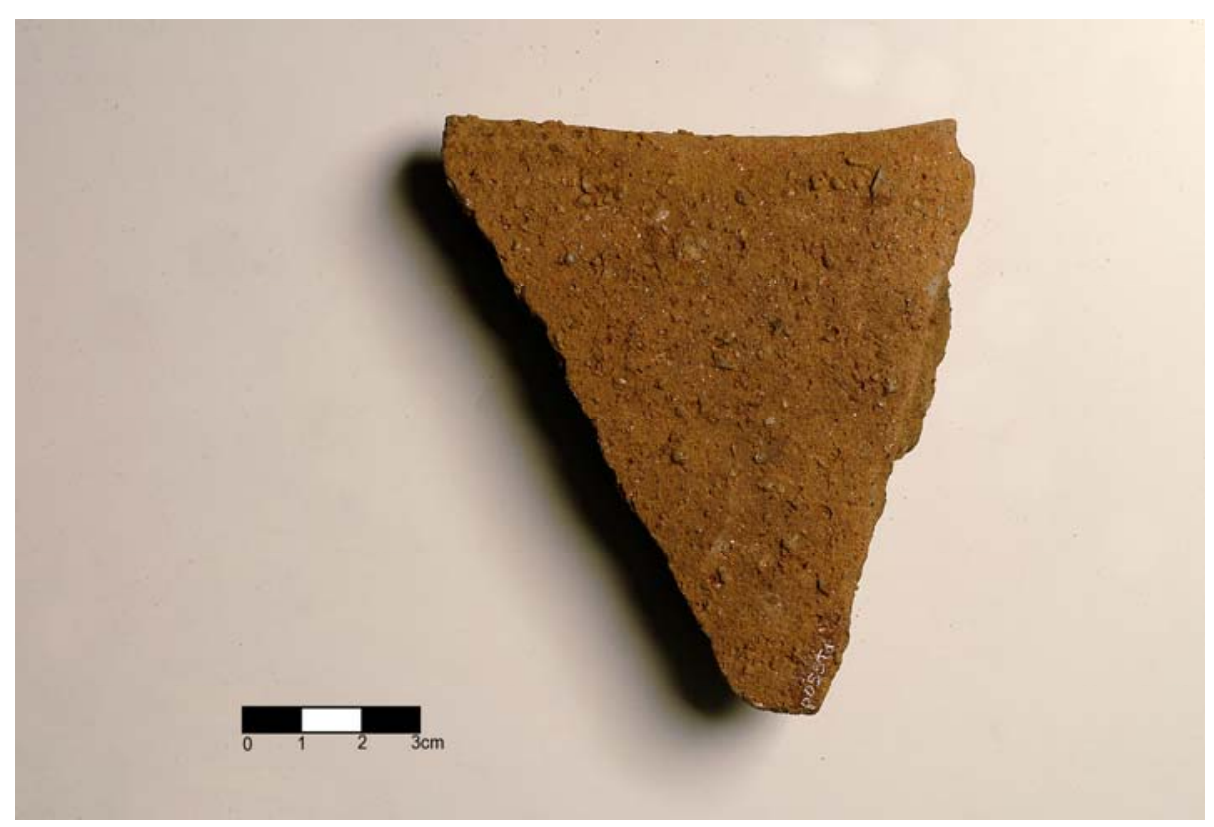

Foto: Souza, 2008.

Foto 41: Sítio Menezes-Fragmento de Bojo

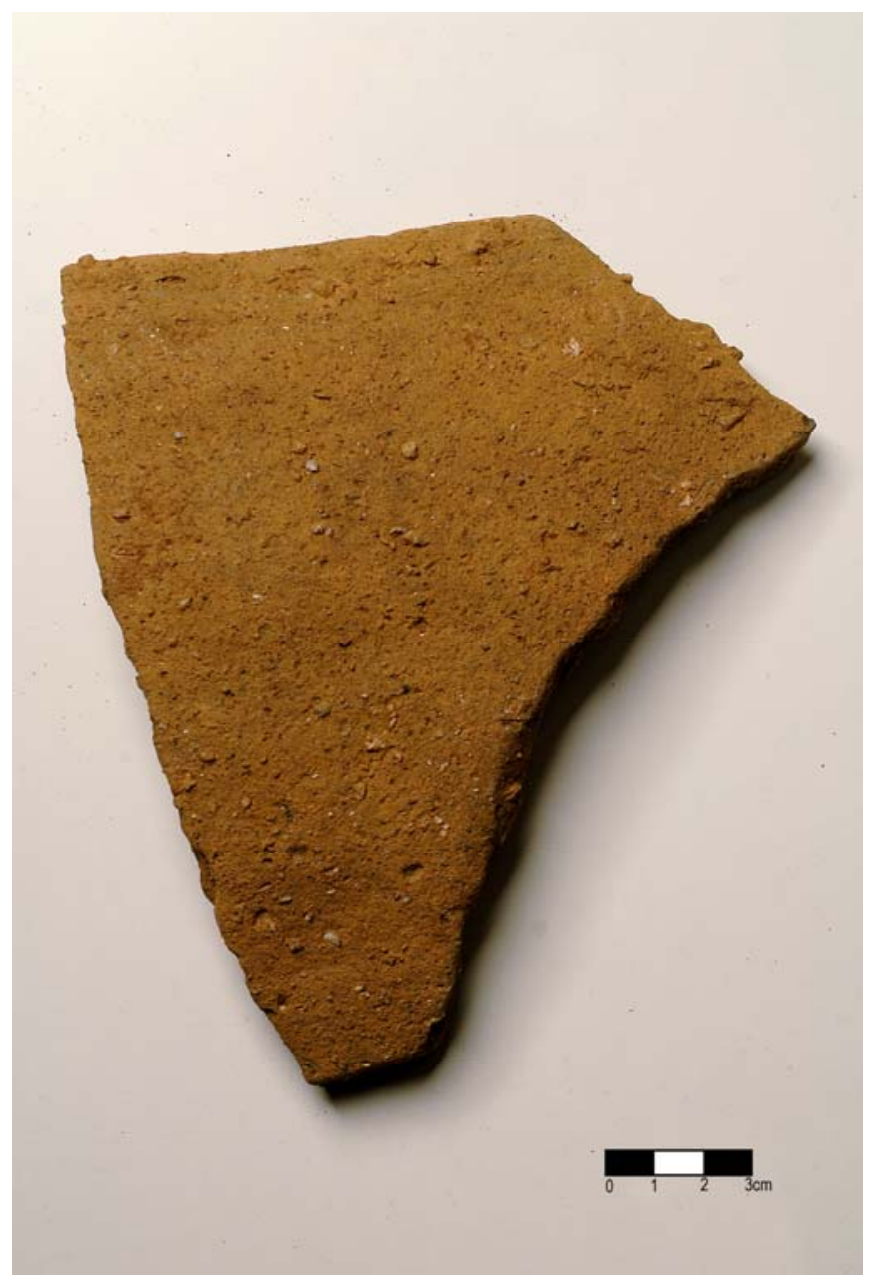

Foto:Souza, 2008 
Foto 42: Sítio Menezes -Fragmento de borda

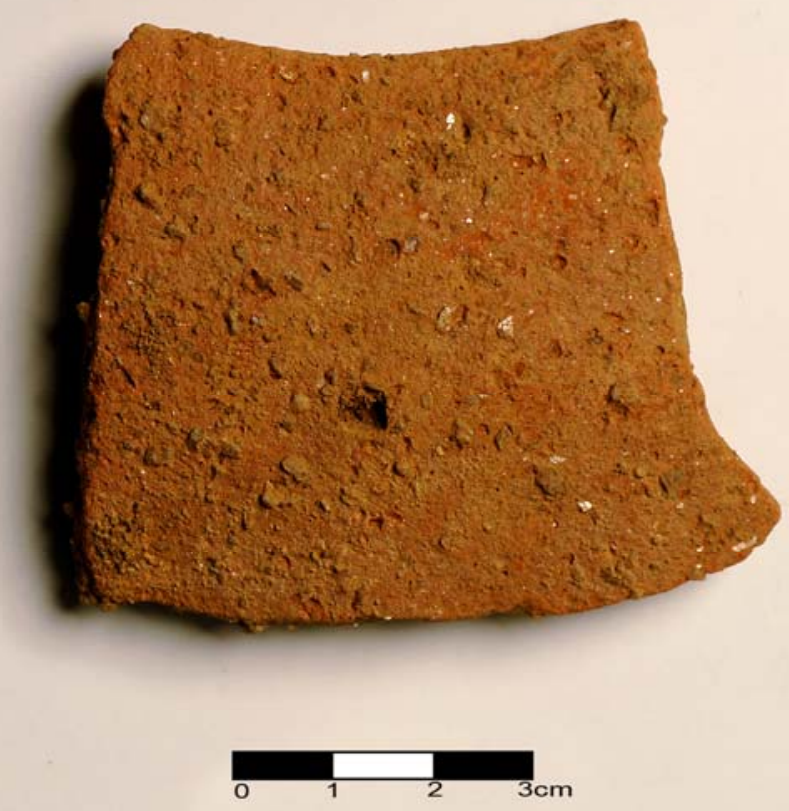

Foto: Souza, 2008.

Foto 43: Sítio Menezes -Fragmento de base
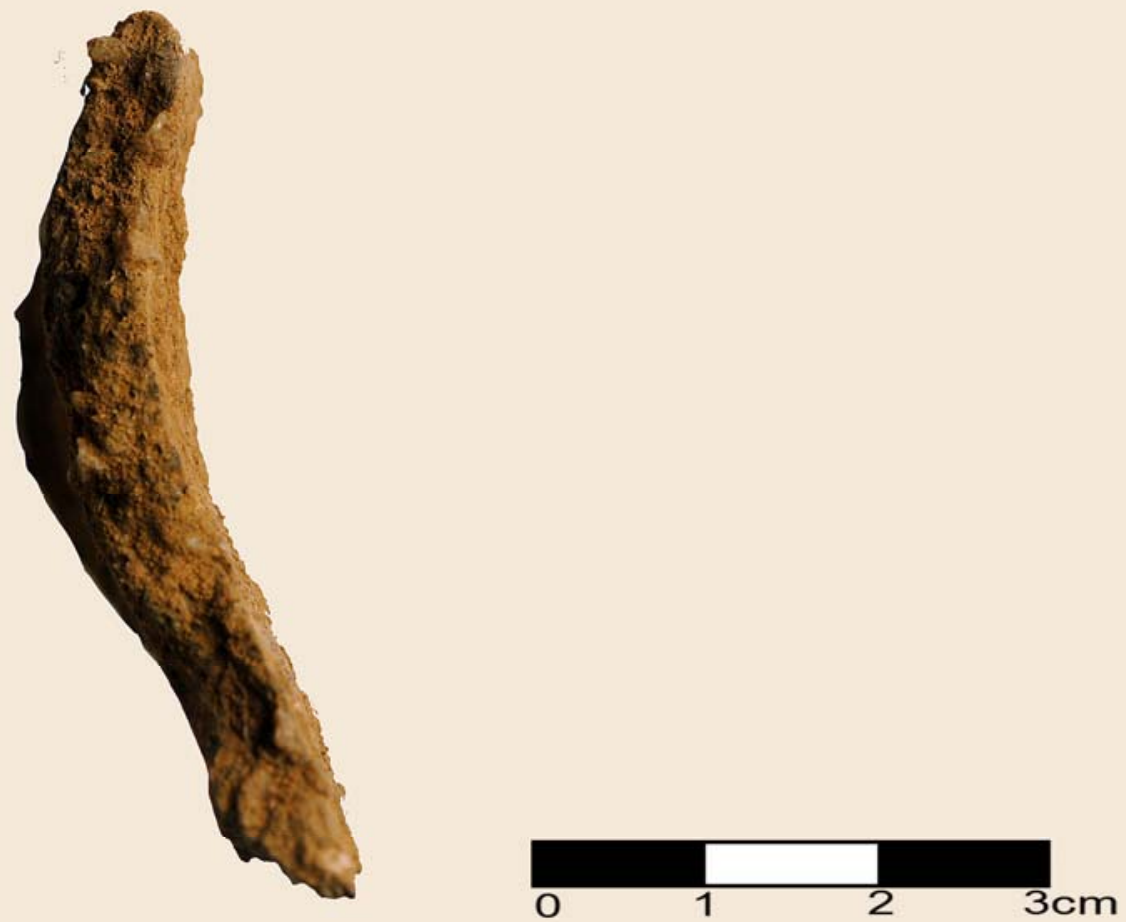

Foto: Souza, 2008. 
Foto 44: Sítio Menezes-Borda Cerâmica

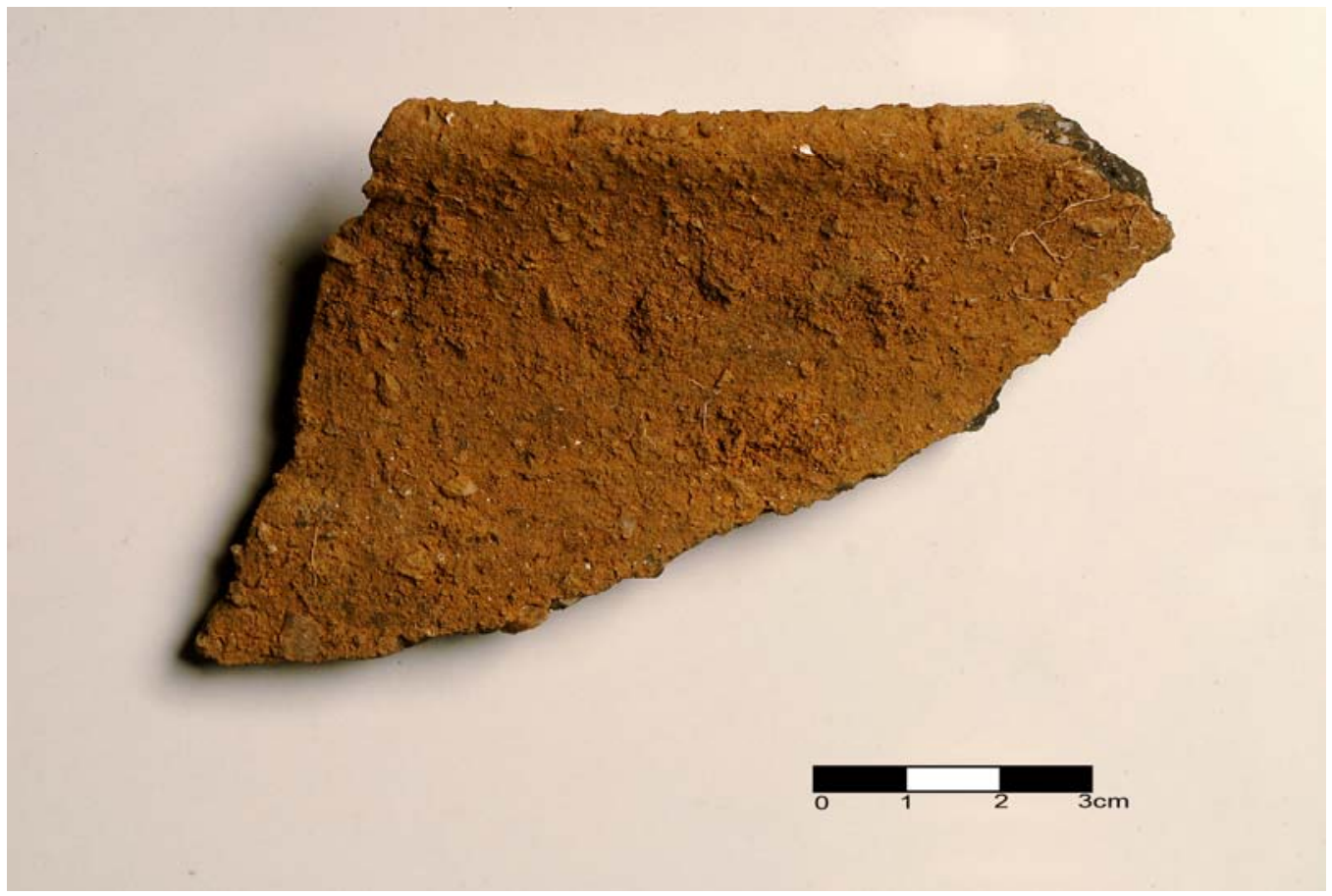

Foto: Souza, 2008.

Foto 45 - Sítio Menezes -Fragmento de Borda

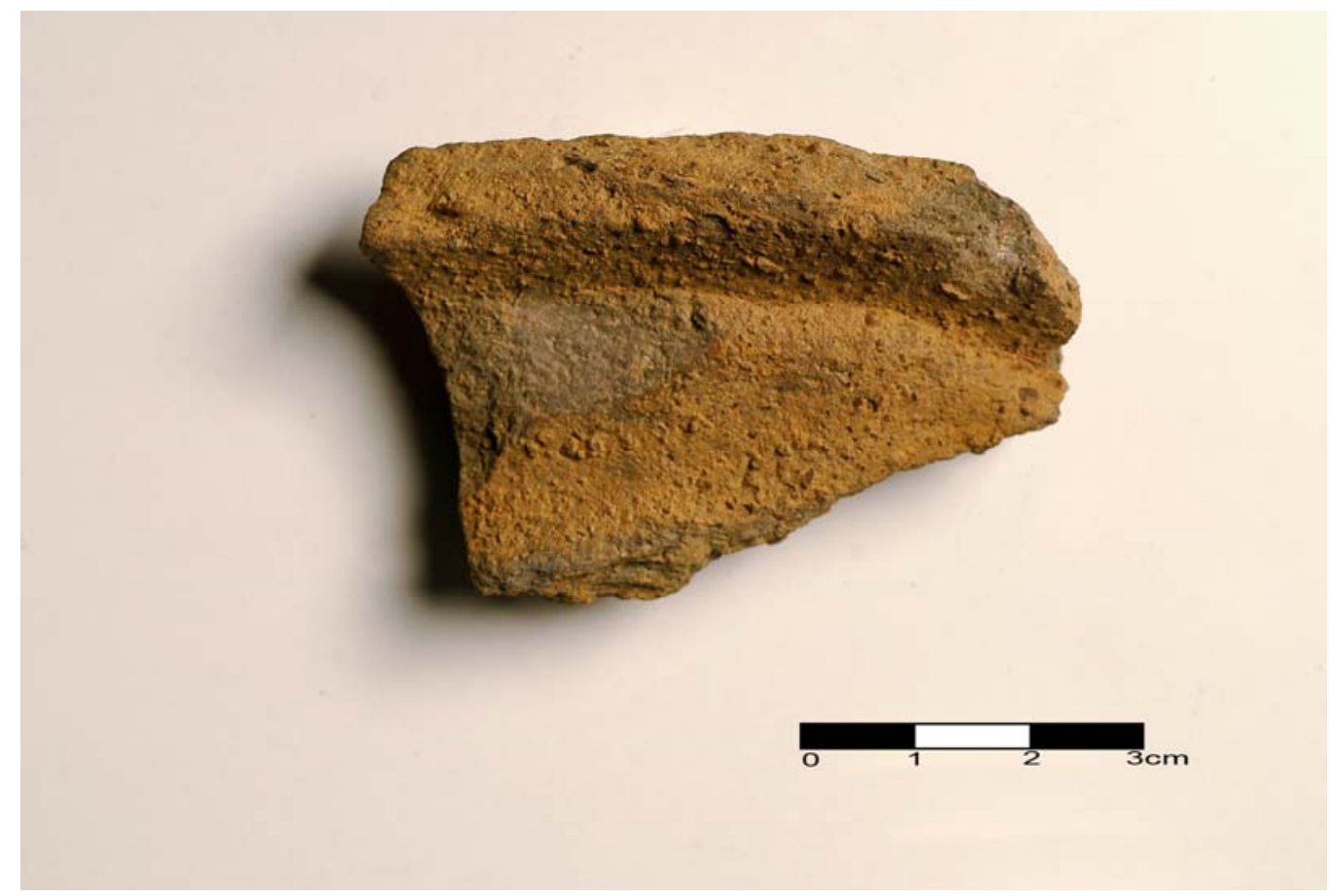

Foto: Souza, 2008. 
Foto 46: Sítio Menezes -Fragmento de Bojo

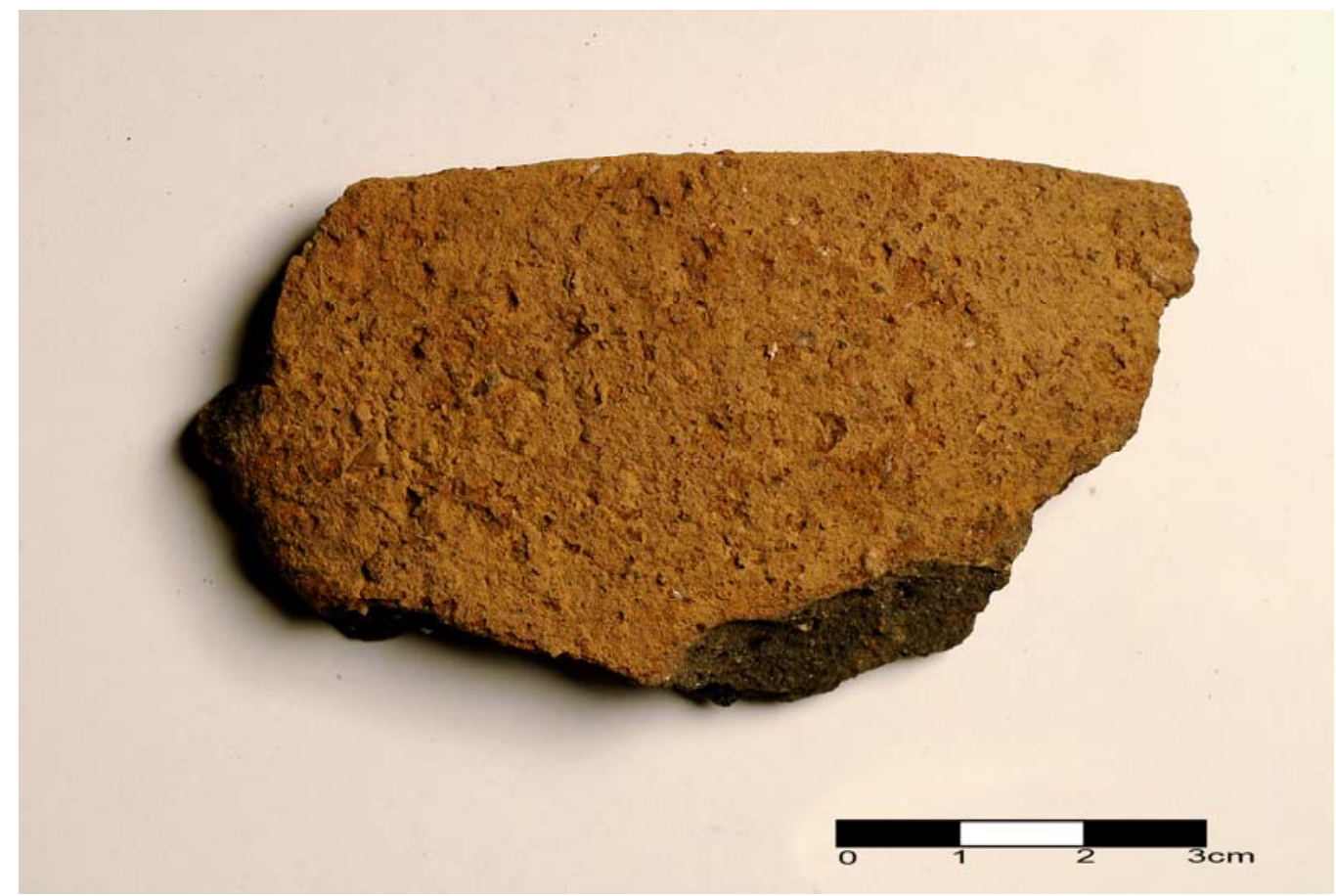

Foto: Souza, 2008.

Foto 47: Sítio Menezes- Fragmento de Borda

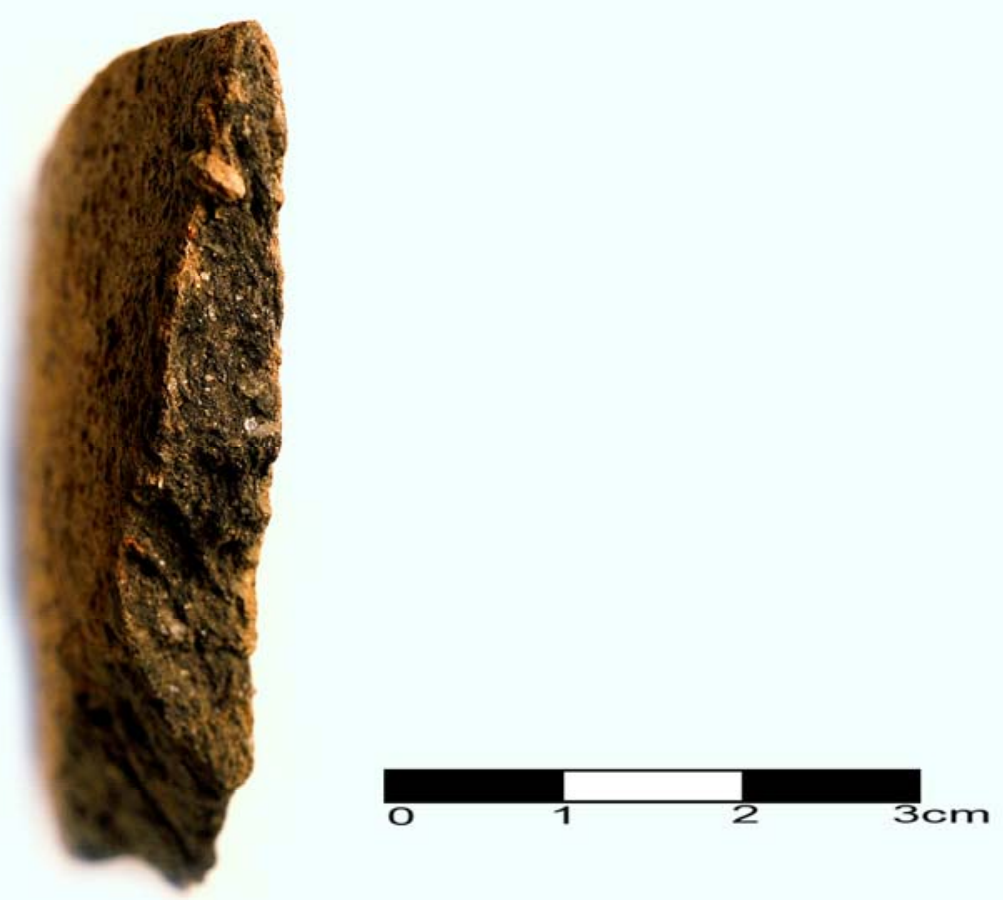

Foto: Souza, 2008. 
Foto 48: Sítio Menezes- Fragmento de base

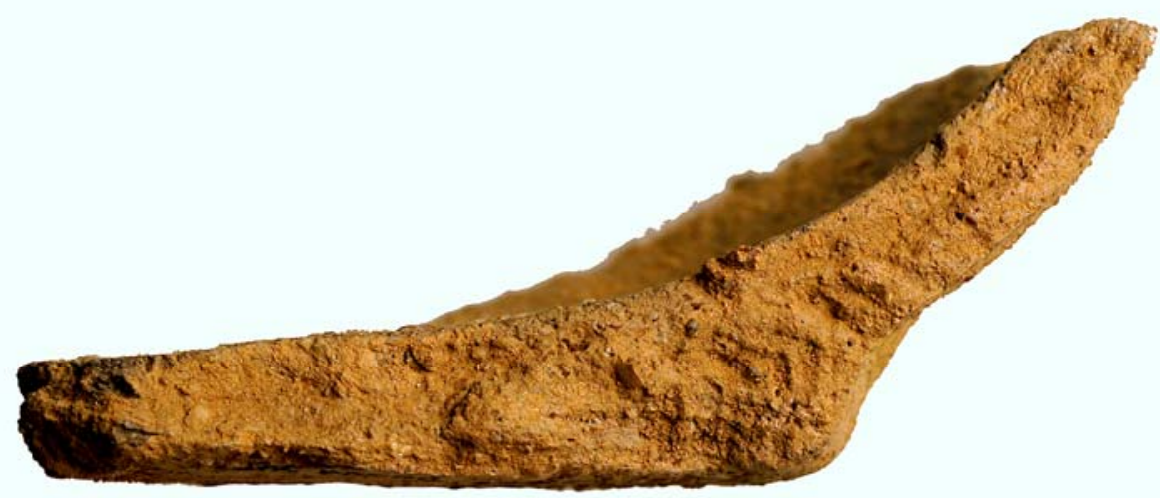

Foto: Souza, 2008.

Foto 49: Sítio Menezes -Fragmento de Base

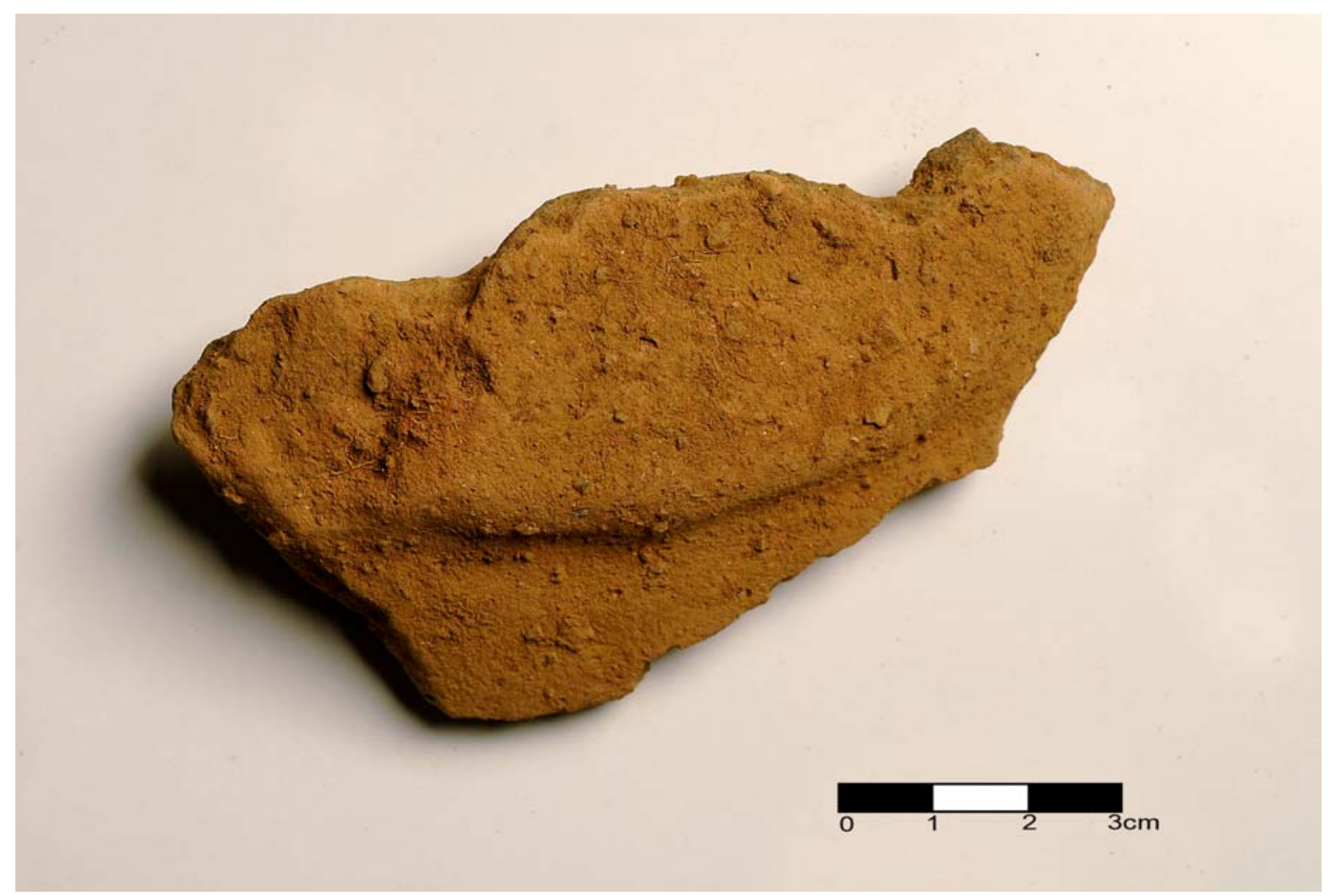

Foto: Souza, 2008. 
Foto 50: Sítio Menezes -Fragmento de borda

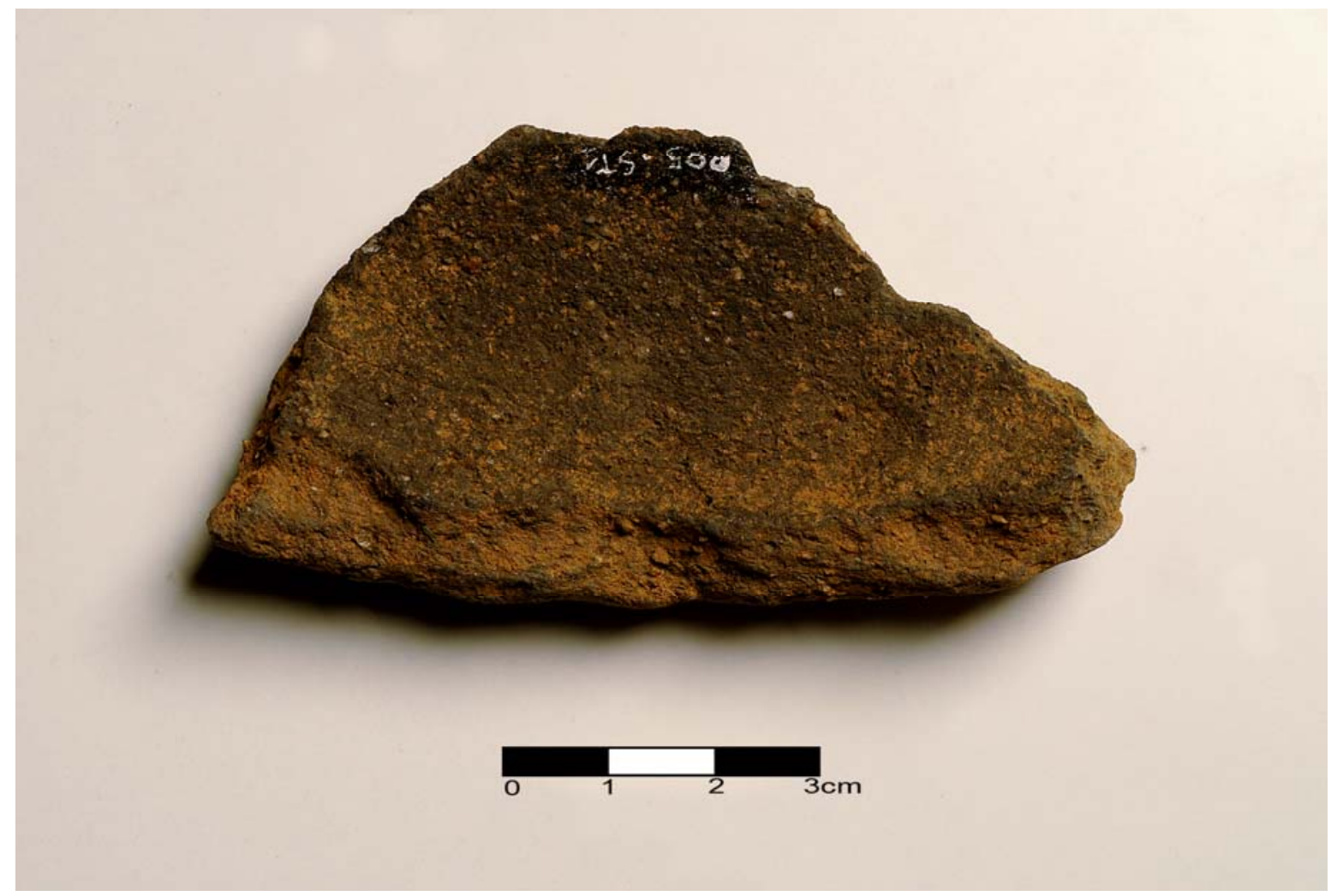

Foto:Souza,2008

Foto 51: projeto Quebra-Anzol-Fusos de Cerâmica

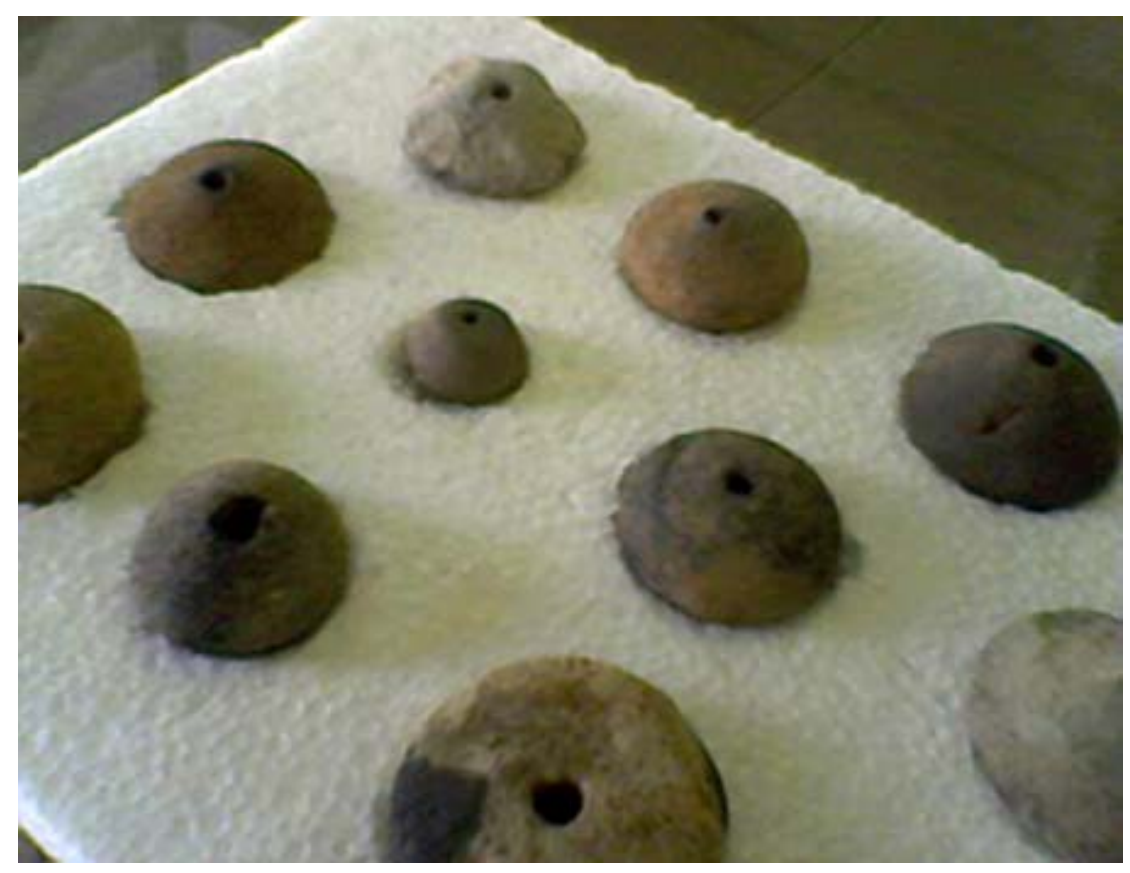

Foto: Figueiredo,2008. 
Foto 52: Sítio Menezes- Fuso de cerâmica

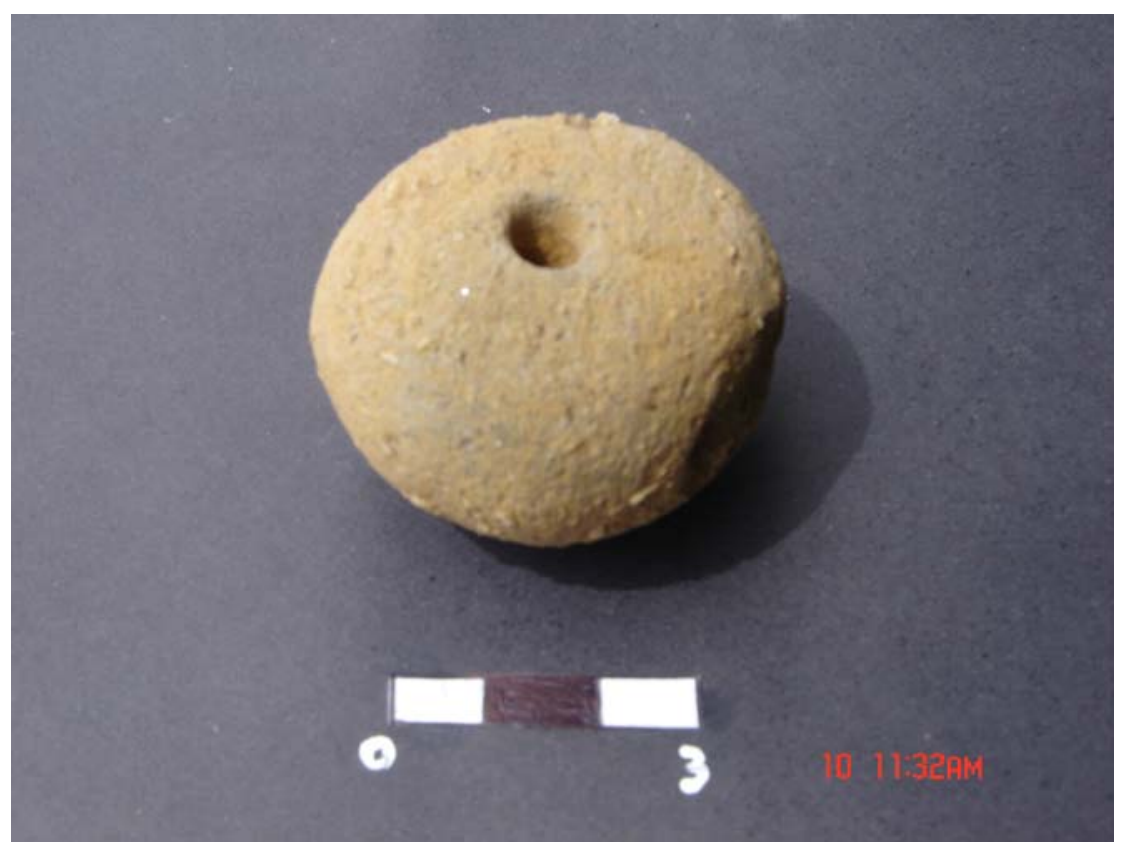

Foto: Figueiredo, 2008. 


\section{Capítulo 5 - Reconstituição dos vasilhames do sítio Menezes e a análise das lâminas pela técnica da microscopia petrográfica.}

\subsection{Breve Análise das cerâmicas reconstituídas}

De acordo com Meggers $^{6}$ (1970, pg.48), um dos aspectos mais importantes da cerâmica é a forma do vasilhame;os perfis das bordas são indicadores de padronização da manufatura da cerâmica, bem como das técnicas desenvolvidas no grupo.

A análise das formas (contorno) dos vasilhames, reconstituídos foi baseada na classificação de Seronie Vivien (1975 pg 69), que compôs um modelo de formas geométricas e a análise das bases foi feita a partir do referencial elaborado por Igor Chymz (1976).

Prancha 1- Forma esférica e lábios estreitados(Sphère/ Rètrecie) -base convexa Prancha 2 - Forma ovóide e lábios alargados (Ovóide/Evasée) -base cônica Prancha 3 - Forma ovóide e lábios alargados (Ovóide/Evasée)- base cônica Prancha 4 - Forma esférica e lábios estreitados (Sphère/ Rètrecie) - base cônica Prancha 5 - Forma cônica e lábios alargados (Cone/Evasée) -base plana Prancha 6 - Forma em elipse e lábios alargados (Ellipse/Rètricie) -base plana Prancha 7 - Forma ovóide e lábios estreitados (Ovóide/ Rètrecie)- base cônica Prancha 8 - Forma ovóide e lábios estreitados (Ovóide/ Rètrecie)- base cônica

\section{Uso social}

As formas ovóides, e de base cônica e de maior volume (Prancha 7 e 8) são compostas por Urnas igaçabas(silo), cuja atribuição de uso social é o armazenamento de grãos. Os vasilhames de 5 a 9L (Prancha 1 a 4 ), podem haver sido utilizados como recipiente de transporte de grãos e as de pequeno volume, 1,6 a 4,41 L, podem atribuir-se diversos usos( oferenda aos mortos, vasilhas para cozinhar.).

\footnotetext{
${ }^{6}$ Para detalhamento das técnicas de reconstituição, olhar referencia:

MEGGERS, B. \& EVANS, C. 1970. Como interpretar a linguagem cerâmica: manual

para arqueólogos. Washinton, Smithsonian Institution, 111p.
} 


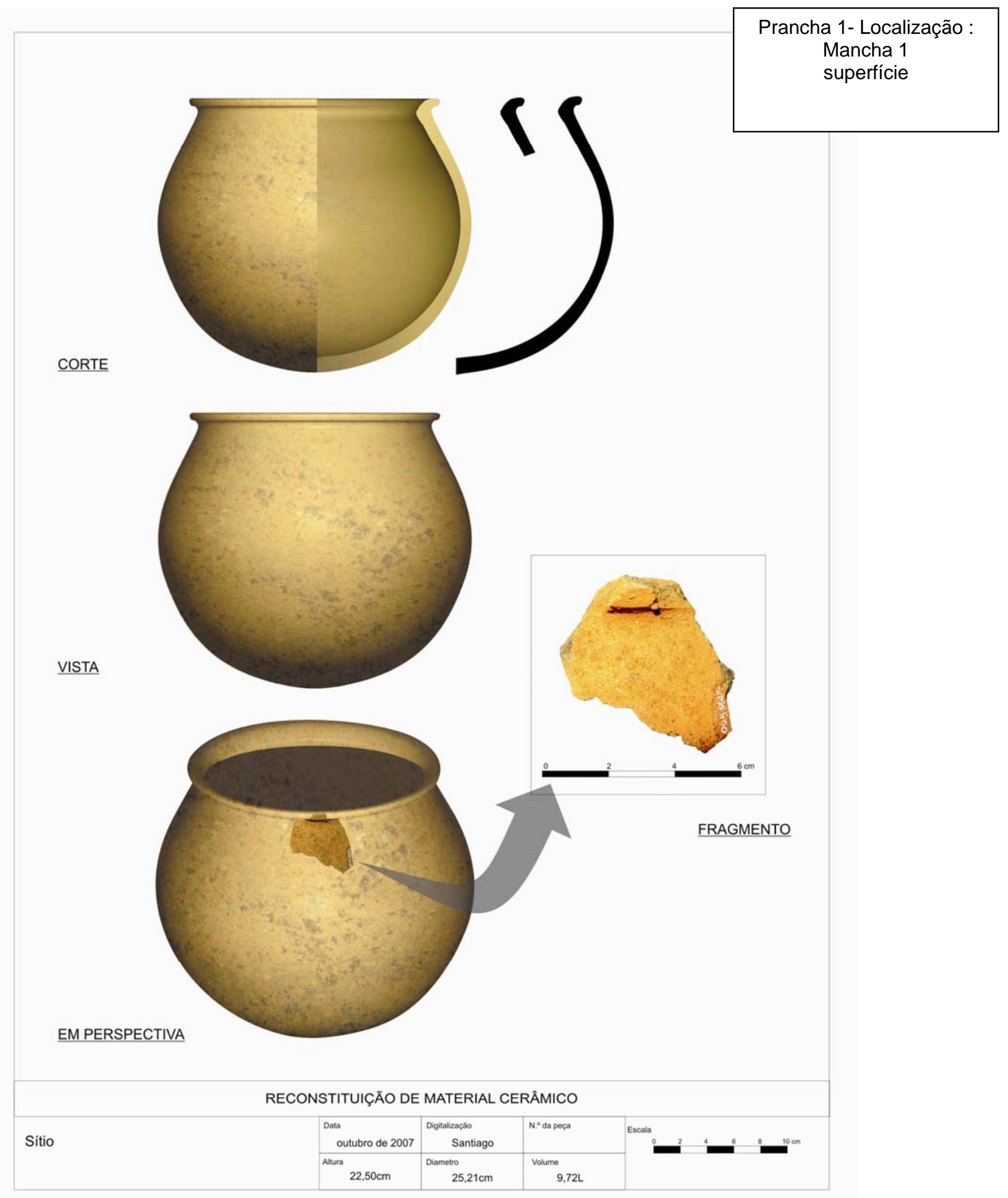


Prancha 2-Localização: Trincheira 3- m 2 -10 a $20 \mathrm{~cm}$ prof.

CORTE

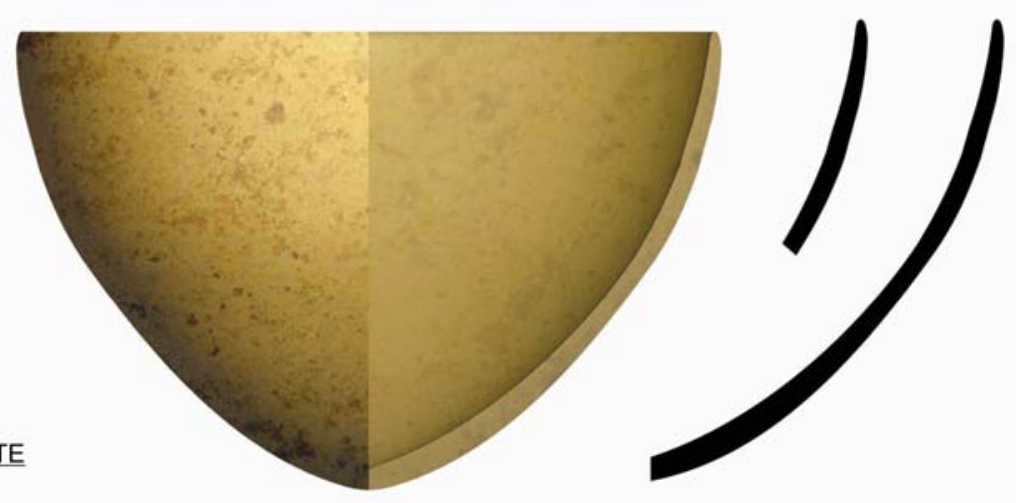

VISTA
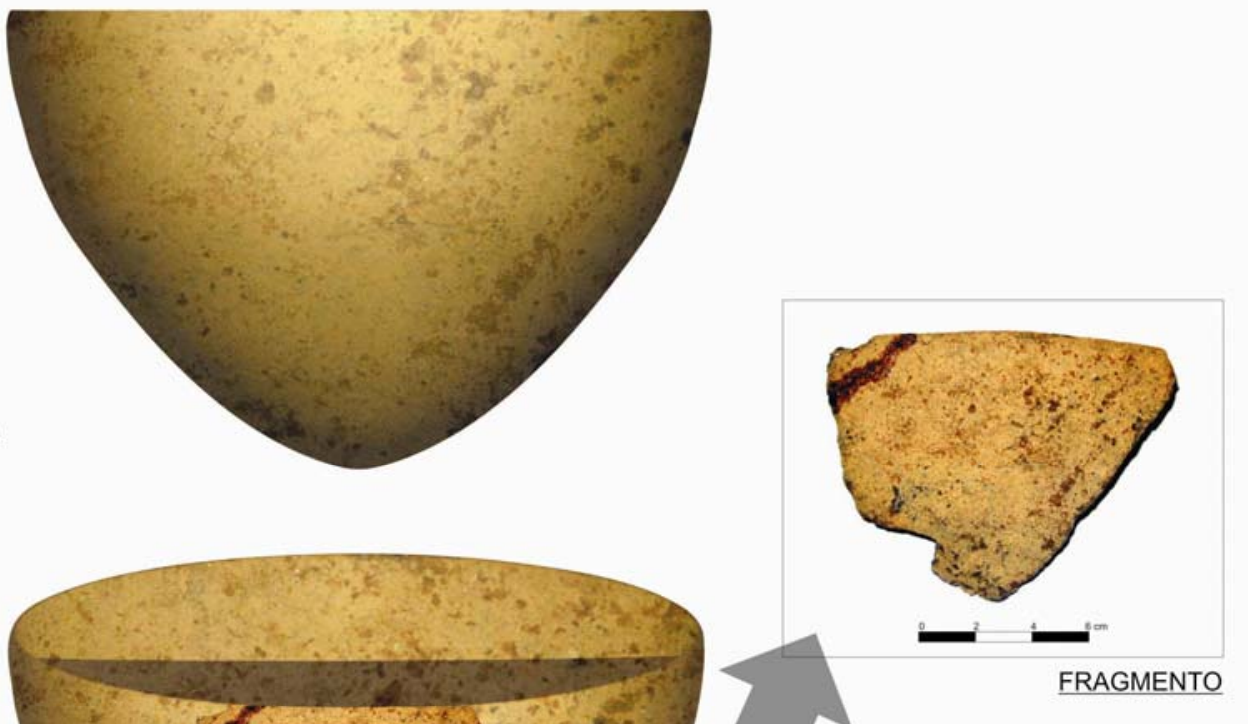

EM PERSPECTIVA

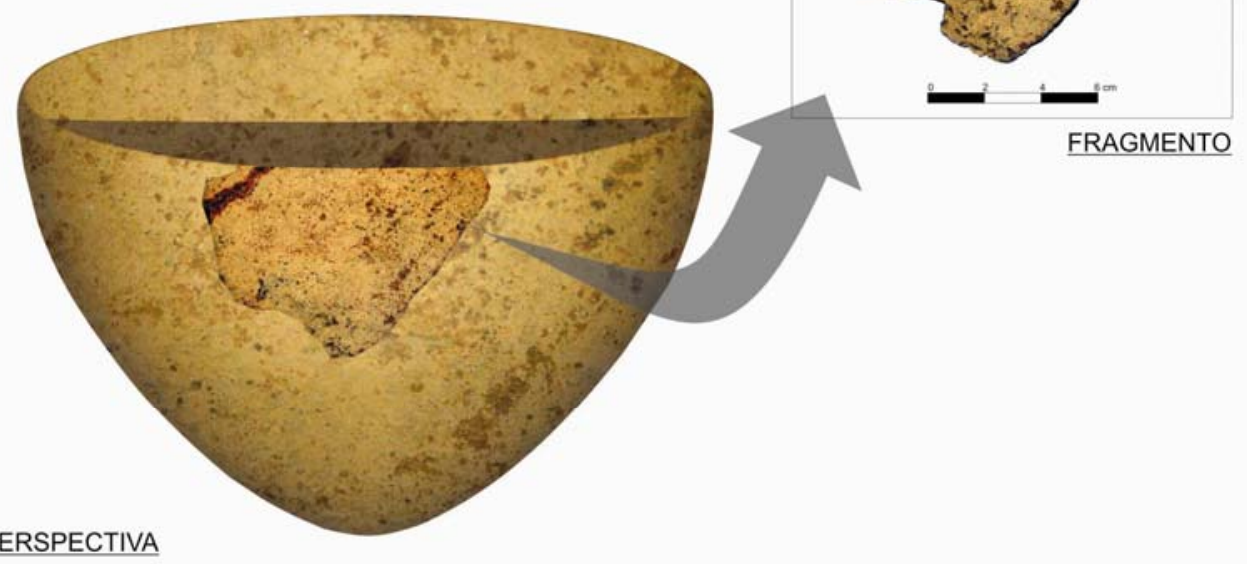

RECONSTITUIÇÃO DE MATERIAL CERÂMICO

\begin{tabular}{|l|l|l|l|}
\hline $\begin{array}{l}\text { Data } \\
\text { outubro de } 2007\end{array}$ & $\begin{array}{l}\text { Digitalizaçilo } \\
\text { Santiago }\end{array}$ & N. da pesa & \\
\hline Alura & Diametro & Volume & \\
$20,43 \mathrm{~cm}$ & $31,02 \mathrm{~cm}$ & $5,14 \mathrm{~L}$ & \\
\hline
\end{tabular}




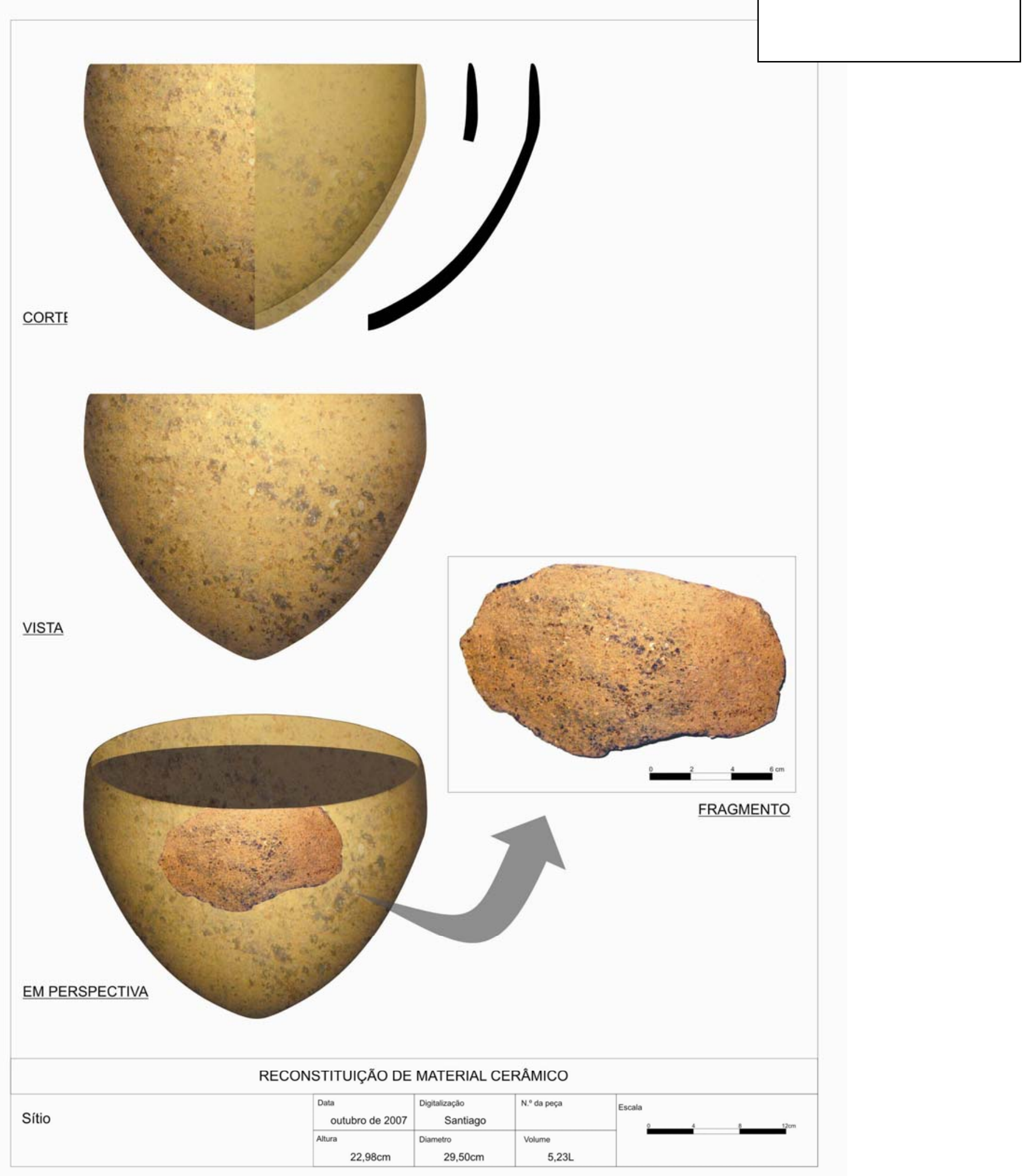


Prancha 4 :Localização

Trincheira 2/ metro1-2

Superfície

CORTE

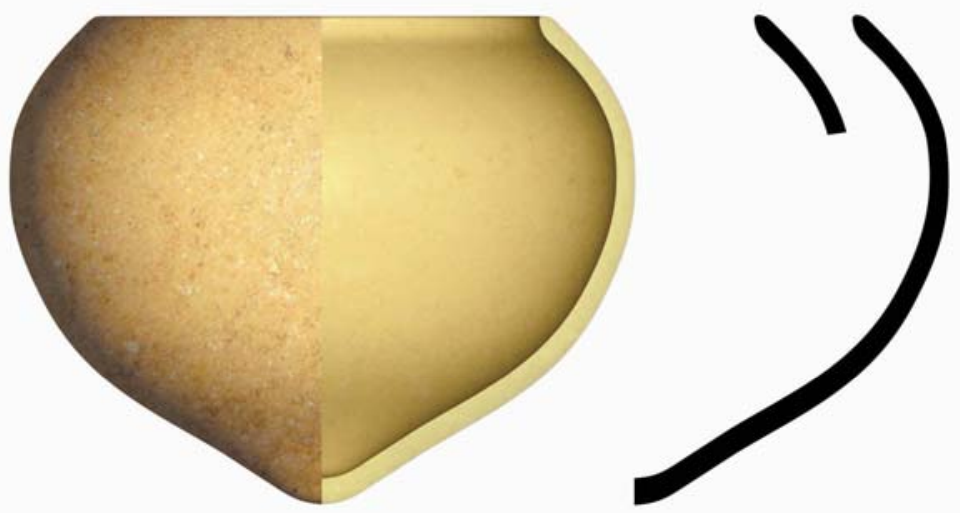

VISTA
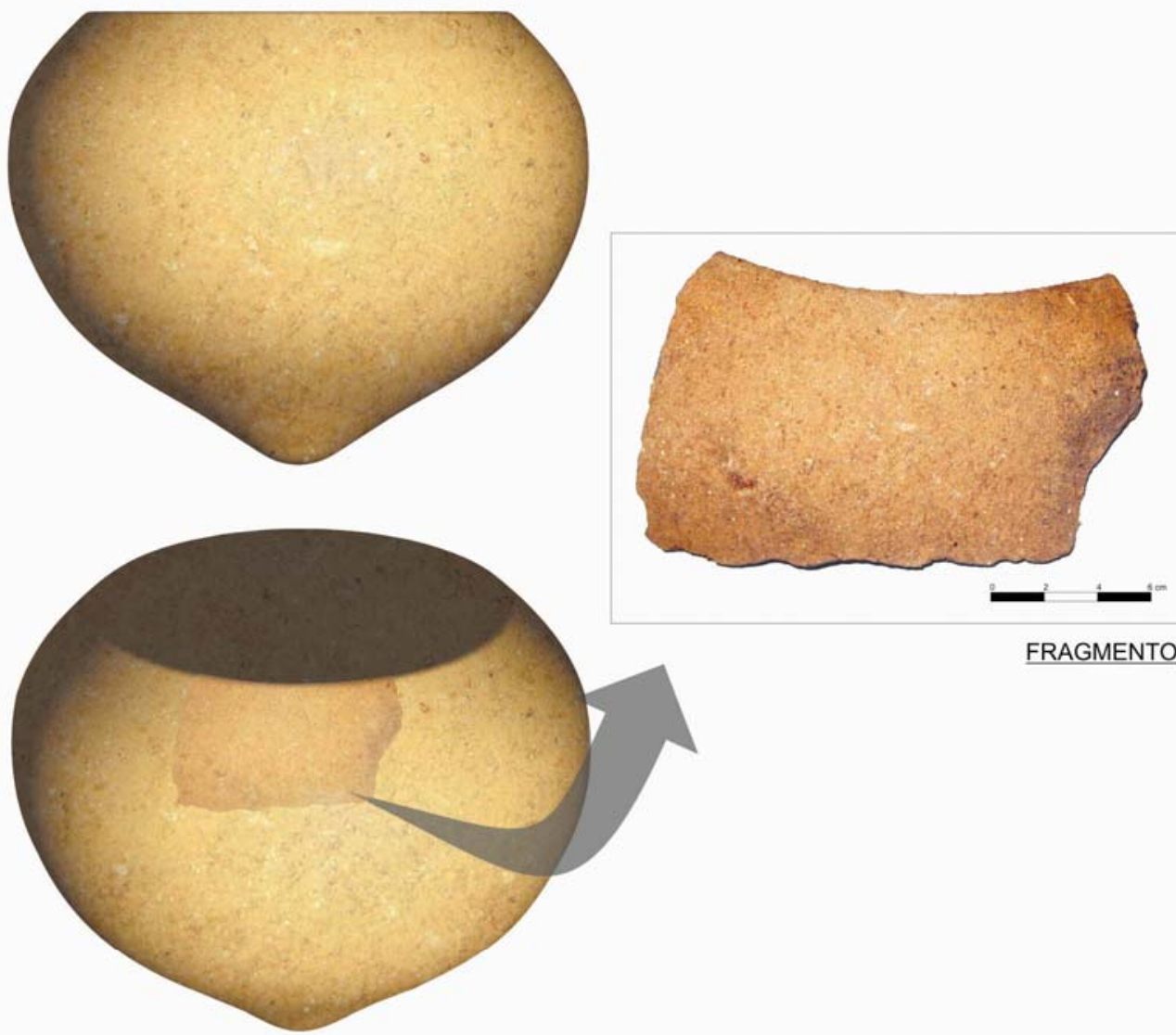

FRAGMENTO

EM PERSPECTIVA

RECONSTITUIÇÃO DE MATERIAL CERÂMICO

Sítio

\begin{tabular}{|l|l|l|l|}
\hline $\begin{array}{l}\text { Data } \\
\text { outubro de } 2007\end{array}$ & $\begin{array}{c}\text { Dighatzzaçio } \\
\text { Santiago }\end{array}$ & N. da pesa & Escala \\
\cline { 1 - 2 } Altura & Diametro & Volume & \\
$37,27 \mathrm{~cm}$ & $47,63 \mathrm{~cm}$ & $57,04 \mathrm{~L}$ & \\
\hline
\end{tabular}


Prancha 5 Localização

Trincheira 2

Mancha 1 -metro 1-2

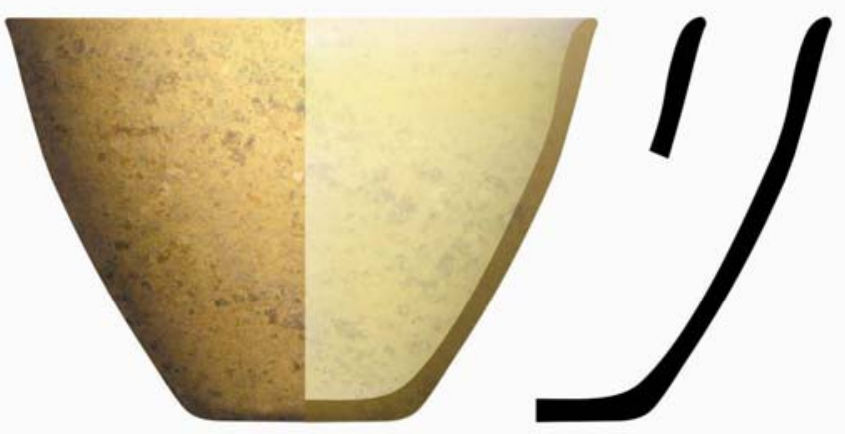

CORTE

VISTA
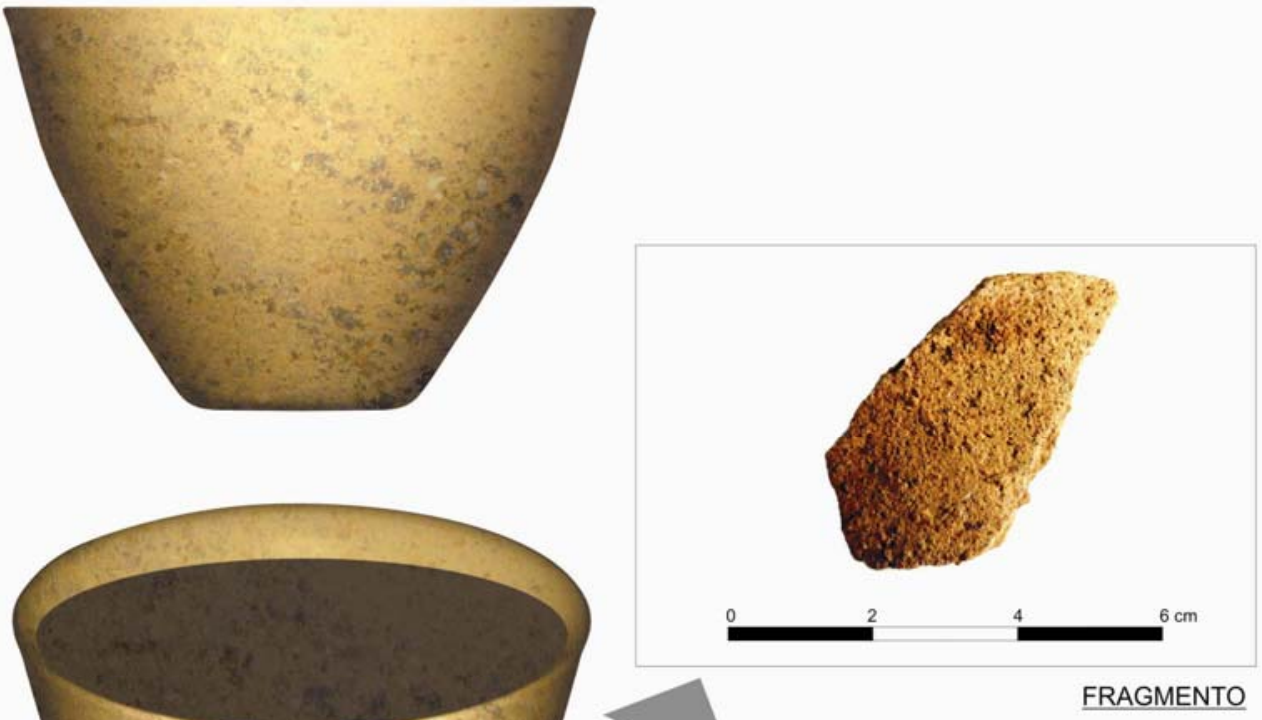

EM PERSPECTIVA

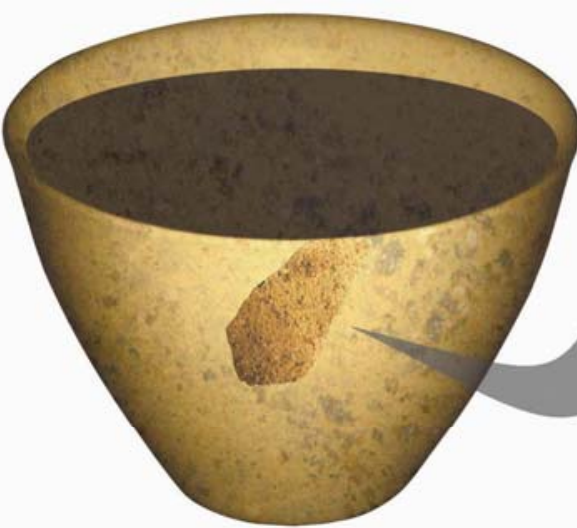

RECONSTITUIÇÃO DE MATERIAL CERÂMICO

Sitio

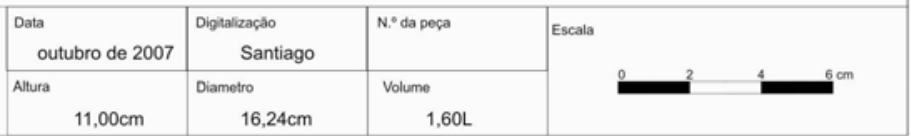




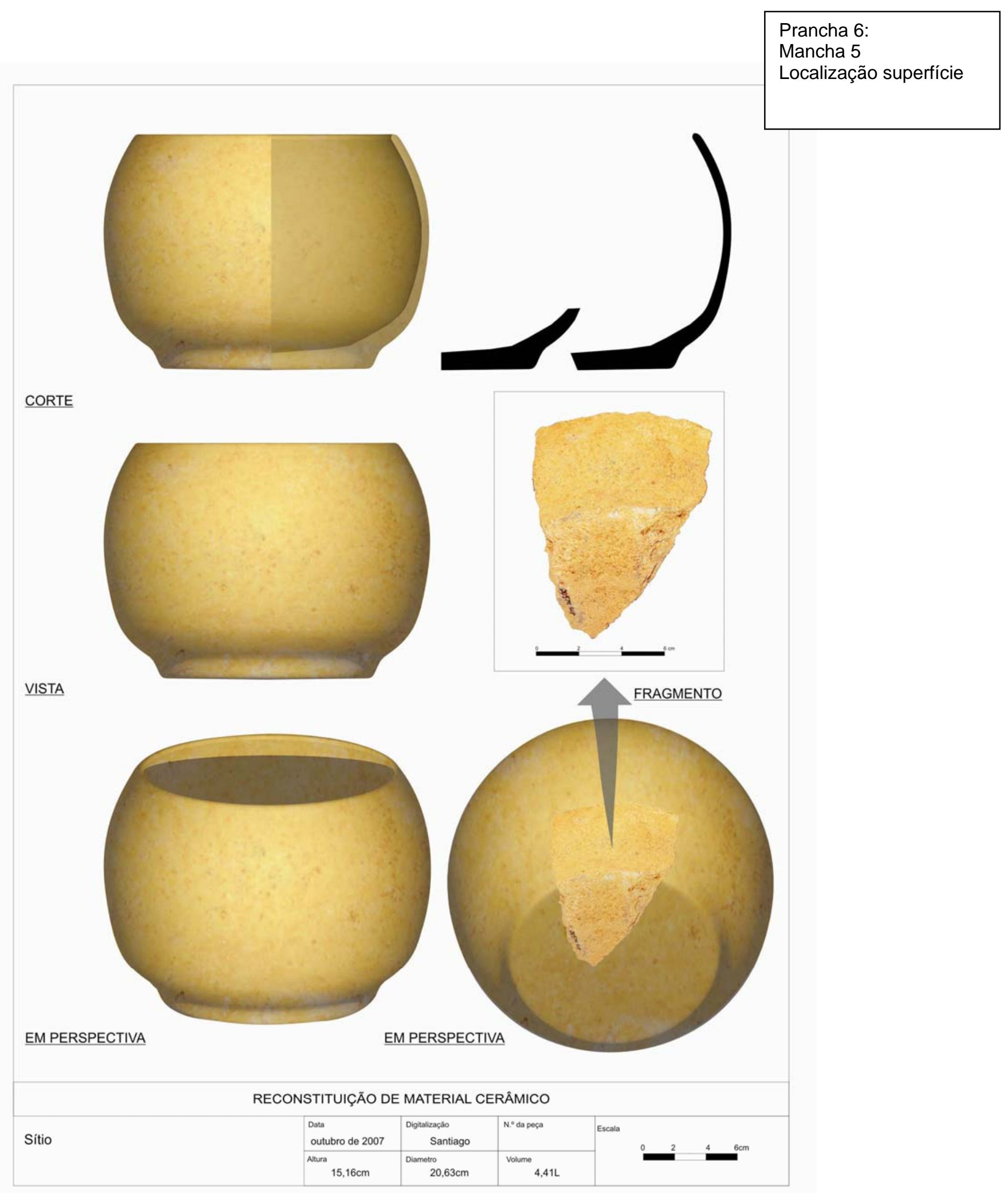




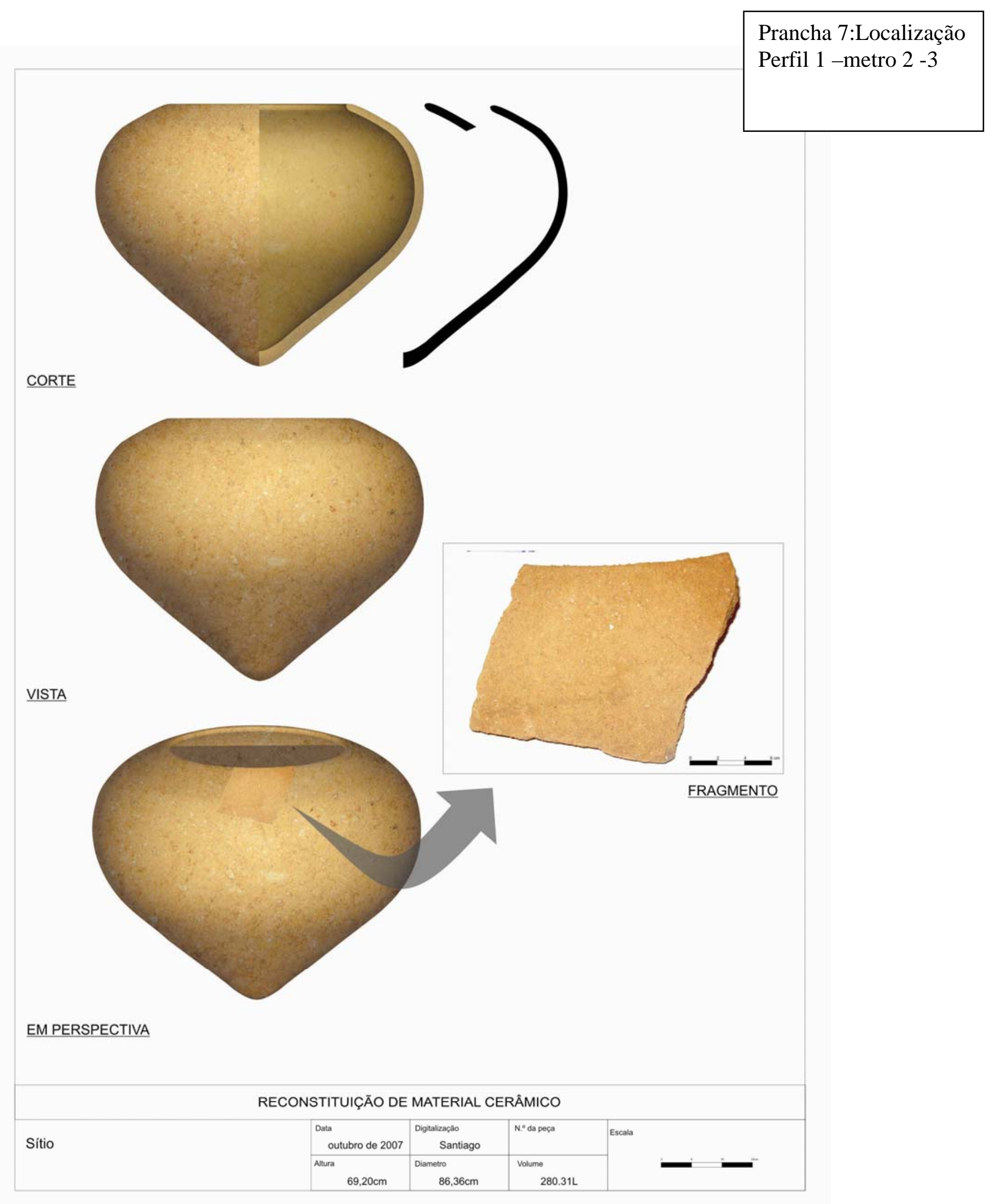


CORTE

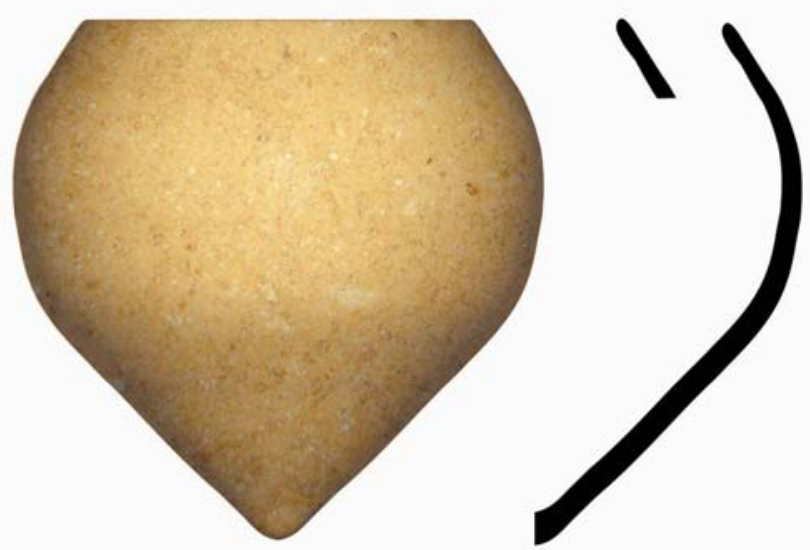

VISTA
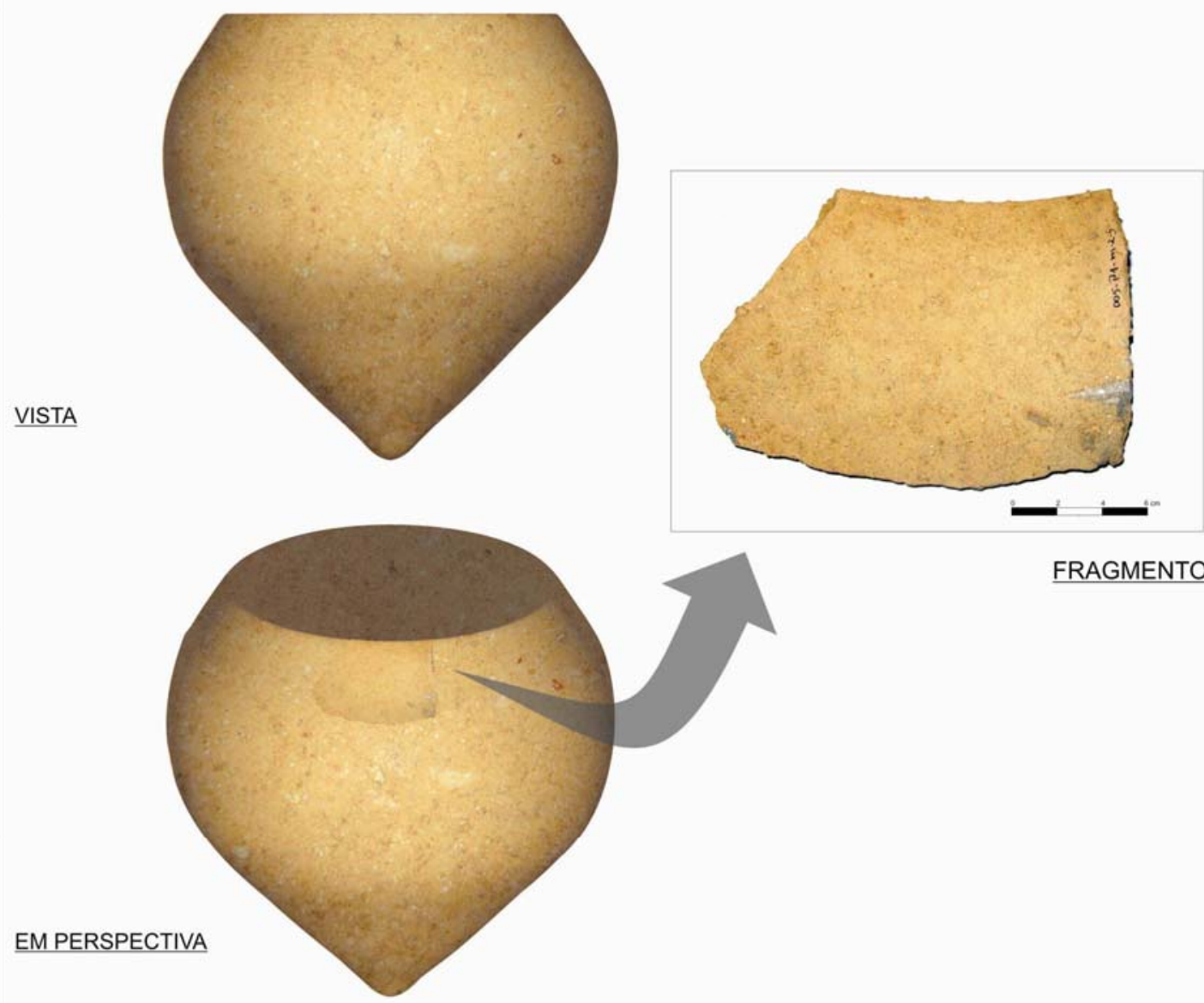

FRAGMENTO

RECONSTITUIÇÃO DE MATERIAL CERÂMICO

Sítio

\begin{tabular}{|c|c|c|c|}
\hline $\begin{array}{l}\text { Data } \\
\text { outubro de } 2007\end{array}$ & $\begin{array}{l}\text { Digitalizaça } \\
\text { Santiago }\end{array}$ & N. da pesa & Escala \\
\hline Allura & Diametro & Volume & \\
\hline $67,06 \mathrm{~cm}$ & $68,31 \mathrm{~cm}$ & $204,04 \mathrm{~L}$ & \\
\hline
\end{tabular}


Foto 53: Urna exposta no Museu de Arqueologia de Perdizes

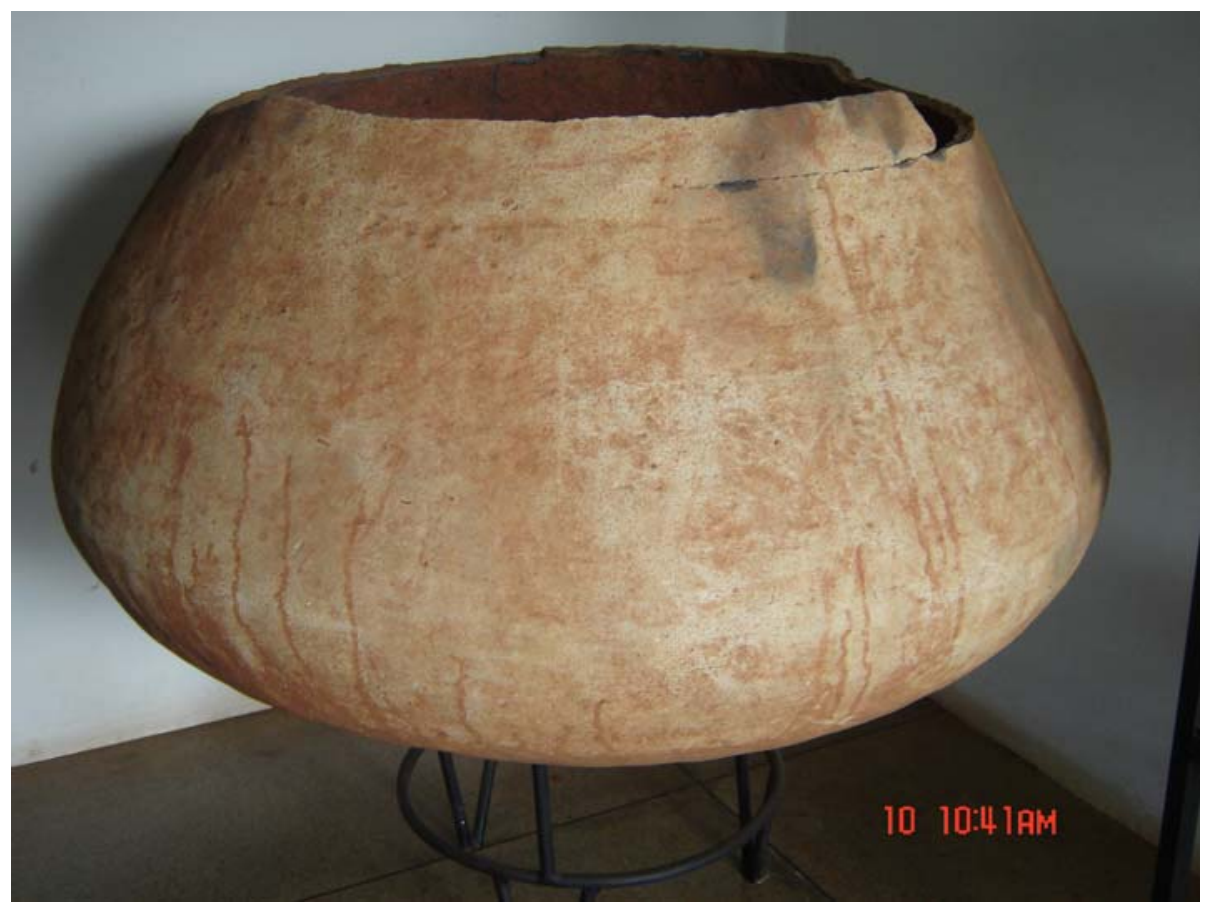

Foto: Figueiredo, 2008.

Foto 54: Urna exposta no Museu de Arqueologia de Perdizes

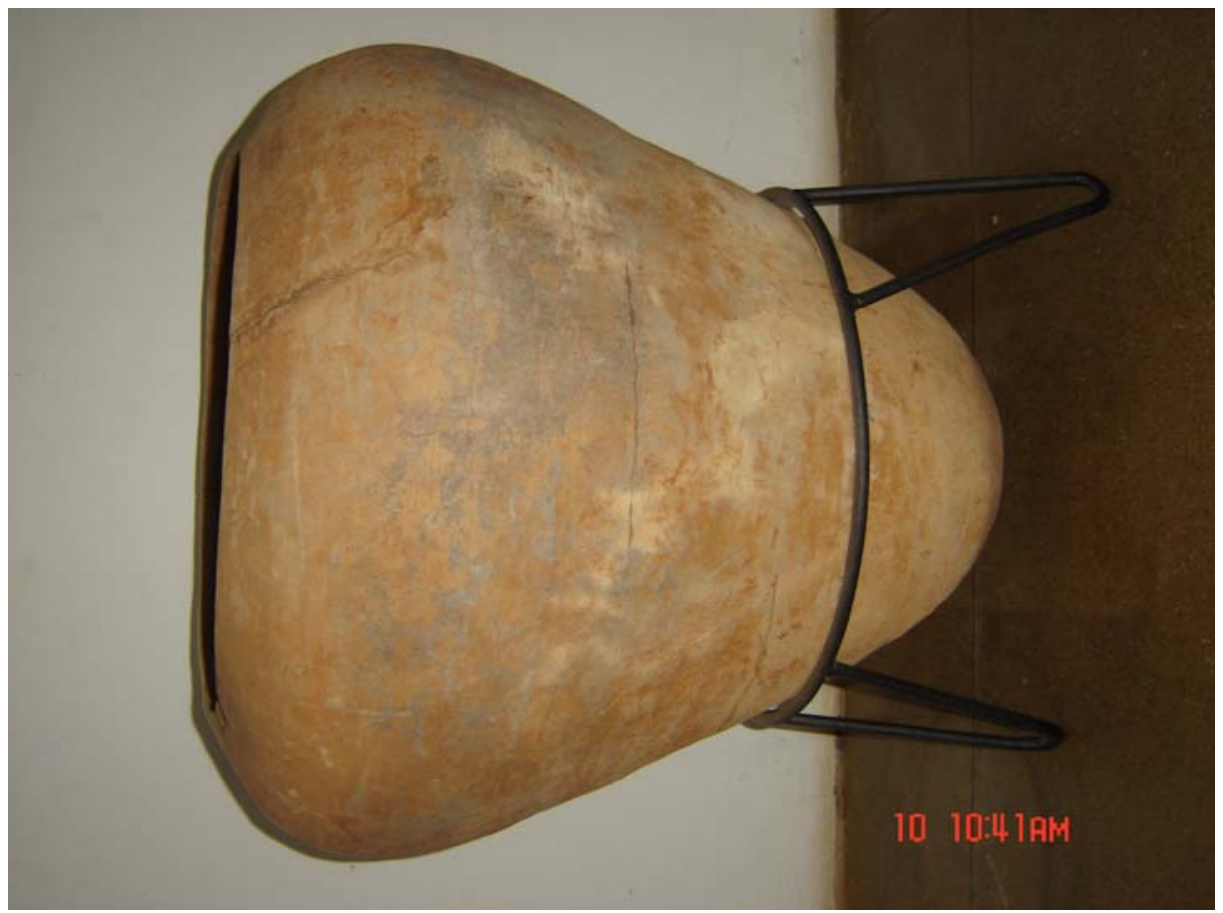

Foto: Figueiredo,2008 


\subsection{As Lâminas Petrográficas}

A análise das Lâminas petrográficas foi realizada pelo Prof.Dr Gergely Szabó do Instituto de Geociências da Universidade de São Paulo, IGC/USP, Brasil.

O modelo do fotomicroscópio utilizado foi Olympus BX50, equipado com câmera digital Jenoptik Progress CT3. As fotos foram tiradas com objetiva $1,25 \times 1$. A técnica utilizada foi a microscopia petrográfica, também conhecida como Luz polarizada transmitida. Esta técnica permite identificar a composição mineralógica da pasta; cada mineral(ângulo) reflete em um determinado tipo de luz.

Foram analisadas cinco lâminas petrográficas, provenientes da mancha 1, mancha 2. mancha 3 , mancha 4 e perfil 1 . O conjunto da amostra apresentou composição mineralógica semelhante.

Toda pasta cerâmica é composta por uma matriz argilosa que atribui plasticidade ao conjunto de minerais que a compõem. Cada partícula de mineral rígido presente na matriz argilosa é chamado de clasto. Desta forma, a maioria dos clastos(grãos) presentes são de quartzo, muito angulosos, poligranulares(aglomerado de grãos) e monogranulaures, de dimensões que variam de $6 \mathrm{~mm}$ a 0,01 $\mathrm{mm}$, provenientes de rochas metamórficas.

O segundo mineral em abundância é a Mica, presente em maior quantidade do tipo branca, moscovita e biotita; os clastos de Mica estão dispostos em palhetas individuais ou agregadas; possuem formado alongado e que se inclinam de acordo com o fluxo da matriz argilosa, atingido com a modelagem.

O feldspato também é encontrado na composição de todas as lâminas, e apresenta em algumas lâminas o caulim (feldspato transformado).

Os minerais opacos presentes nesta argila, por meio destas técnicas não podem ser identificados em sua totalidade; alguns minerais opacos possuíam continuidade espacial com o hidróxido de ferro.

Todas as lâminas apresentam cristais de turmalina zonada (núcleo azul/ borda verde). 


\section{Dados de interesse etnográfico}

De acordo com alguns minerais encontrados, pode-se sugerir sobre um contexto de escolha cultural: o quartzo presente em toda a amostra é muito anguloso, fato que demonstra que a pasta foi retirada de uma fonte protegida do intemperismo físico e químico, como, por exemplo, encostas ou barrancos(saprólitos), pois, se este quartzo pertencesse a uma região próxima aos rios, apresentaria superfície arredondada, modelada pela ação das águas;

O feldspato encontra-se em período de transição entre feldspato e o caulim; esta etapa de transformação caracteriza que o minério foi retirado diretamente na rocha presente em encostas ou barrancos(saprólito).

Tanto as características de configuração do quartzo, quanto do feldspato, corroboram a hipótese de transporte rápido da pasta.

De modo geral, a presença dos grãos de quartzo é massiva em todas as lâminas; no entanto na lâmina correspondente à mancha 4, os grãos são maiores e a matriz argilosa é menos densa.

Nenhuma das lâminas apresentou componentes vegetais ou adição de cerâmica triturada(chamota).

Seguem as fotomicrografias das lâminas. 


\section{Mancha 1}

Fotomicrografia 1 -Lâmina 1:proveniente da Mancha 1 /foto filtros polarizadores cruzados

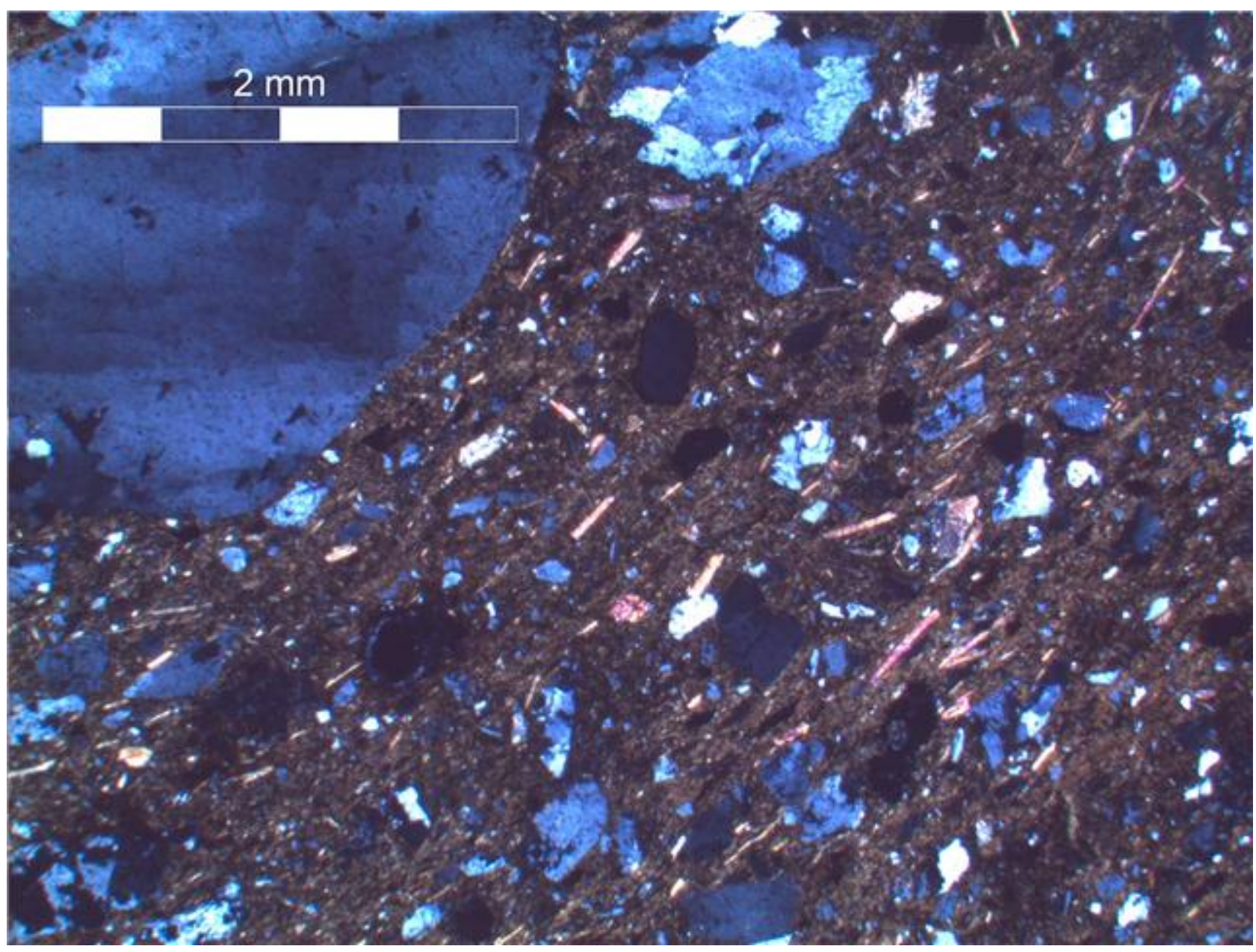

Foto:Szabó, 2008

Grãos de quartzo de diversas dimensões/poligrnulares/monogranulares

Hidróxido de ferro

Minerais opacos 


\section{Mancha 2}

Fotomicrografia 2 -Lâmina 1:proveniente da Mancha 1 /Foto filtros polarizadores paralelos

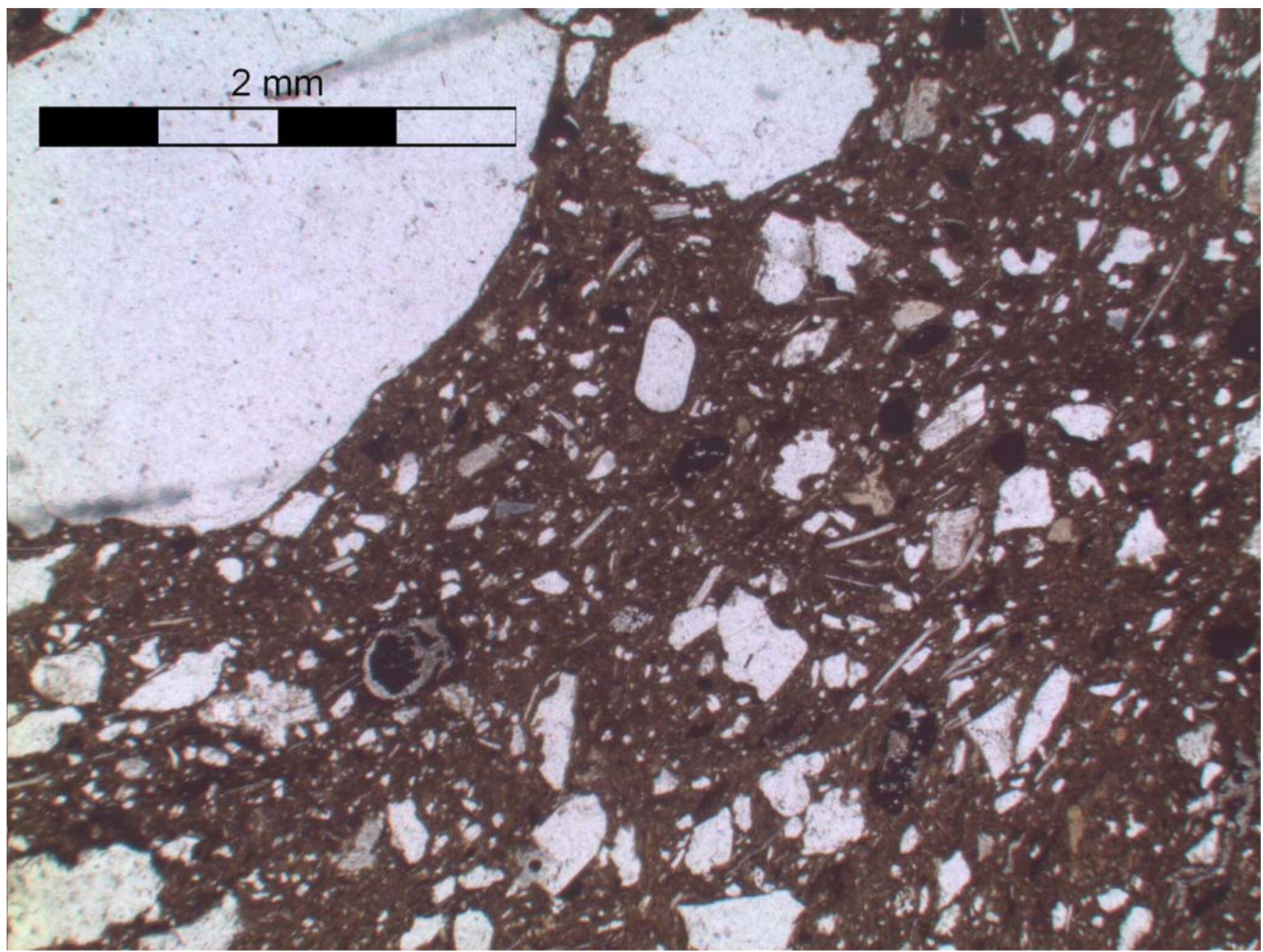

Foto:Szabó, 2008

Grãos de quartzo angulosos e de dimensões variadas

Matriz argilosa

Minerais opacos 
Fotomicrografia 3-Lâmina 2:proveniente da Mancha 2 /Foto filtros polarizadores paralelos

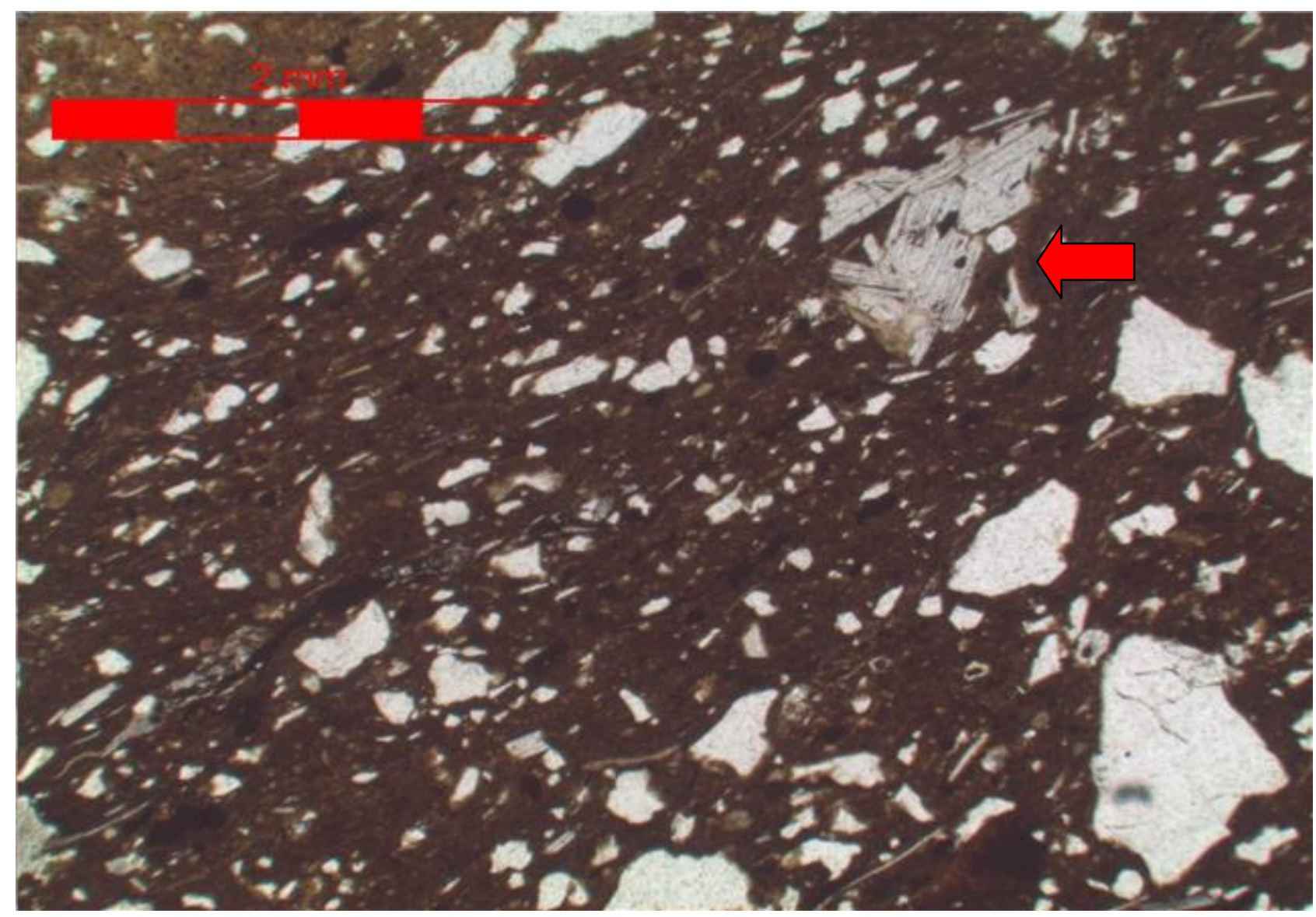

Foto: Szabó,2008

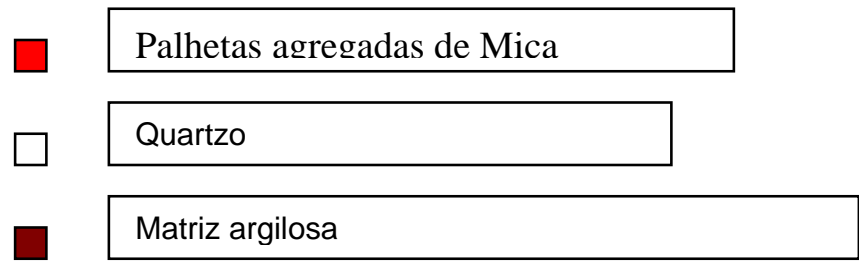


Fotomicrografia 4-Lâmina 2:proveniente Mancha 2 /Foto :filtros polarizadores cruzados

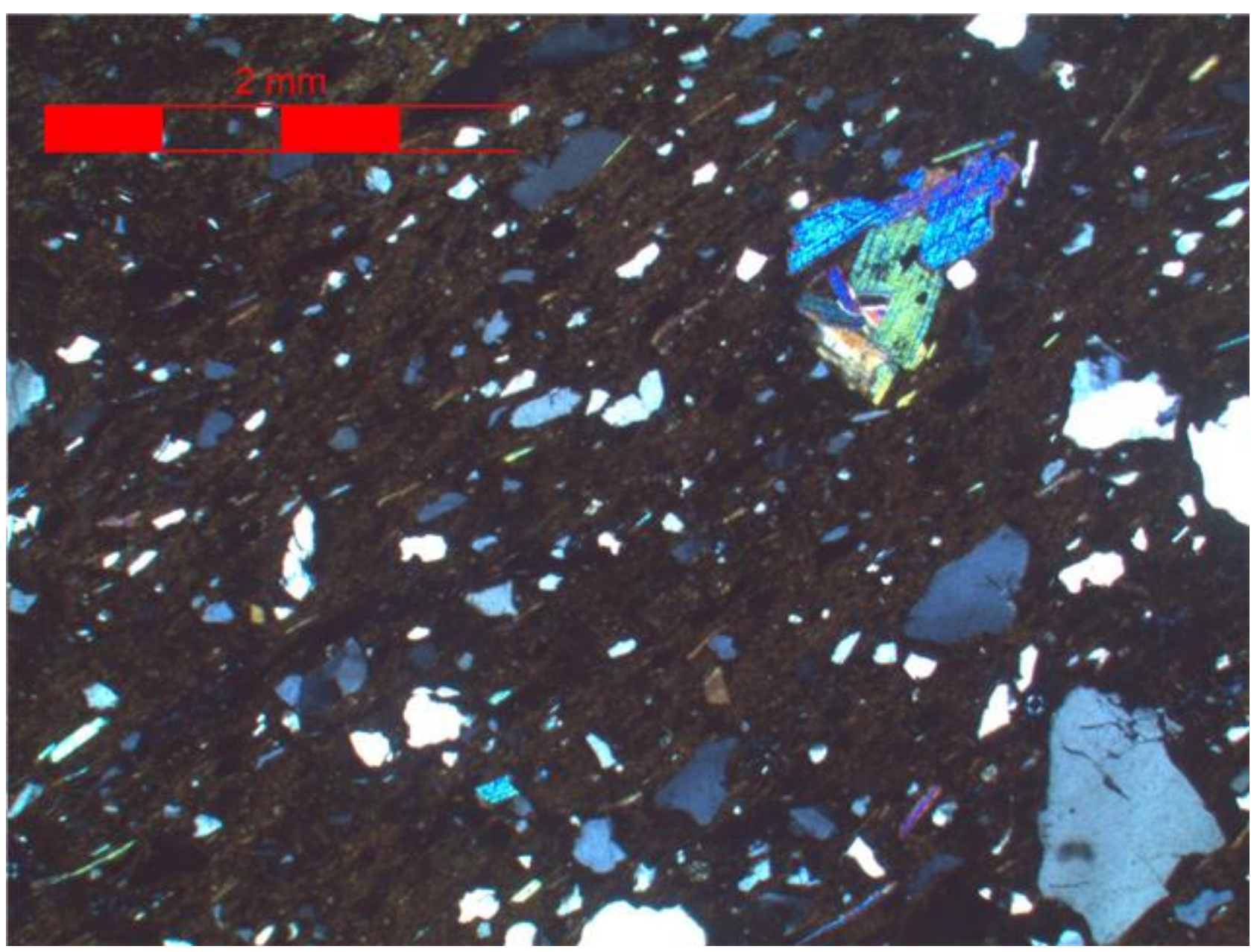

Foto :Szabó,2008

Palhetas agregadas de Mica

Quartzo

Matriz argilosa 


\section{Mancha 03}

Fotomicrografia 5-Lâmina 3:proveniente da Mancha 3 /Foto filtros polarizadores cruzados

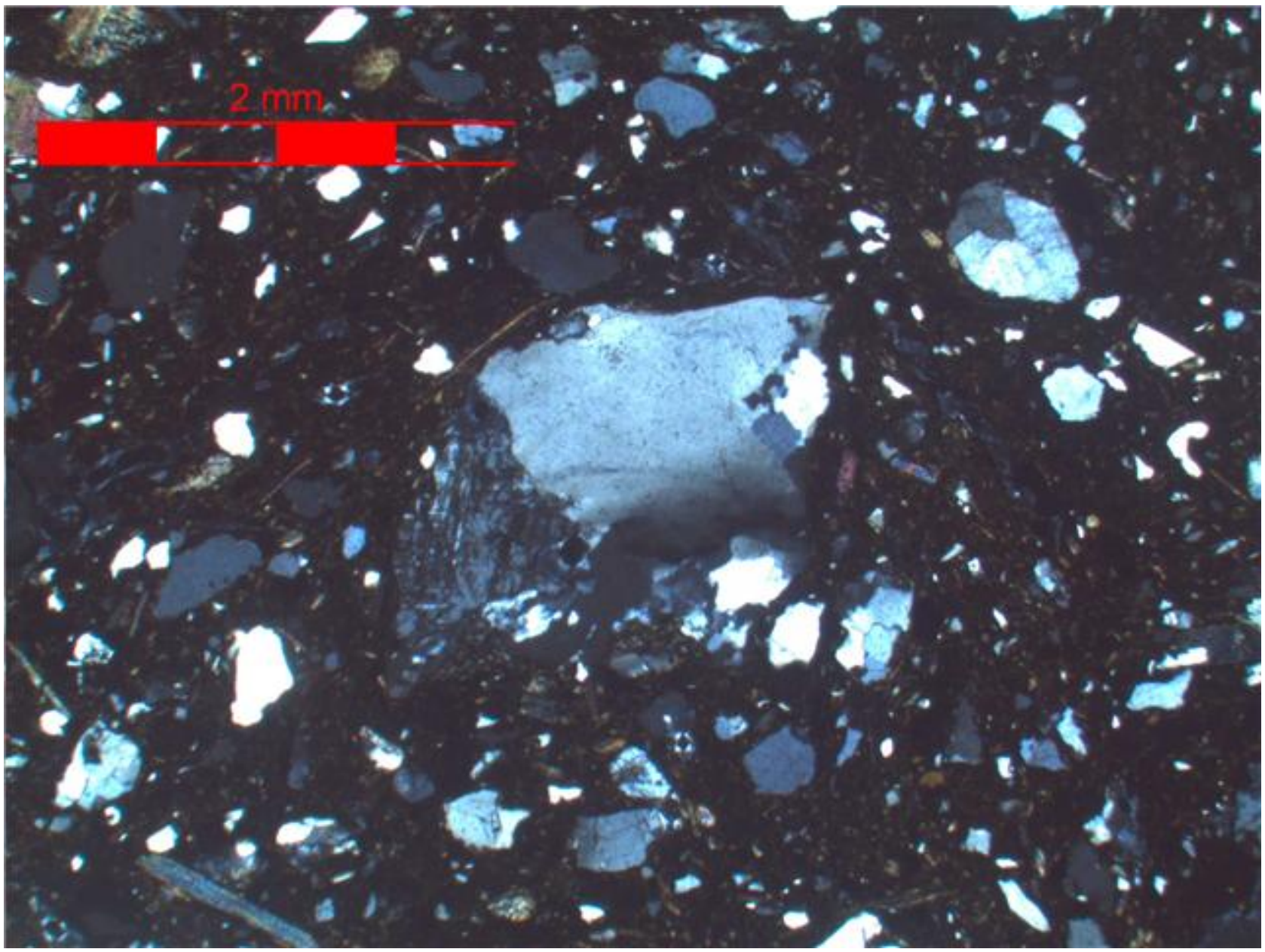

Foto:Szabó,2008 
Fotomicrografia 6-Lâmina 3:proveniente da Mancha 3 /Foto filtros polarizadores paralelos

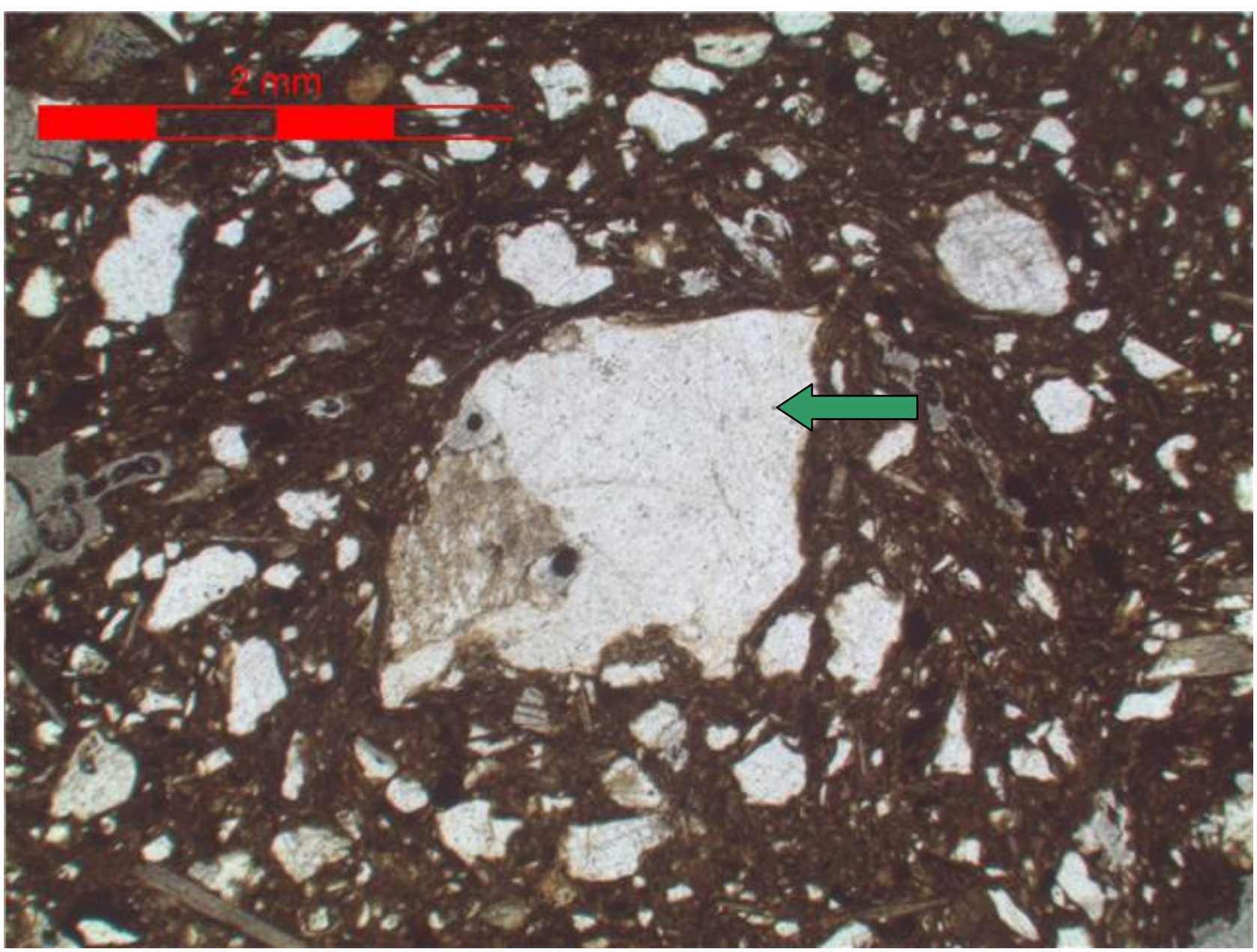

Foto:Szabó,2008

Quartzo poligranular fragmentado

Quartzo

Matriz argilosa 


\section{Mancha 4}

Fotomicrografia 7:Lâmina 3:proveniente Mancha 4- filtros polarizadores paralelos

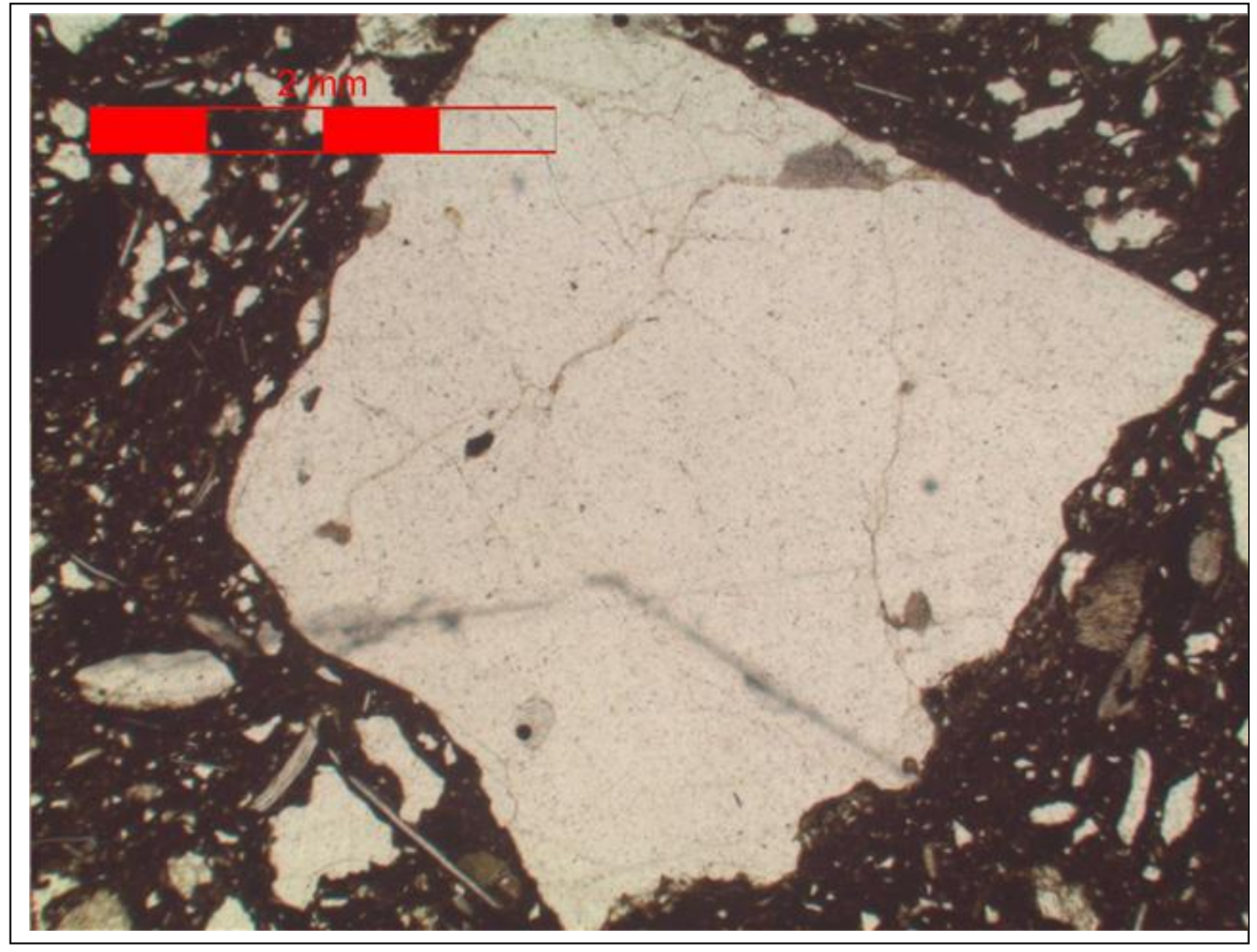

Foto :Szabó,2008.

Quartzo- 6mm envolvido em matriz argilosa

Matriz argilosa 
Fotomicrografia 8: Lâmina 4: proveniente Mancha 4- Foto :filtros polarizadores cruzados

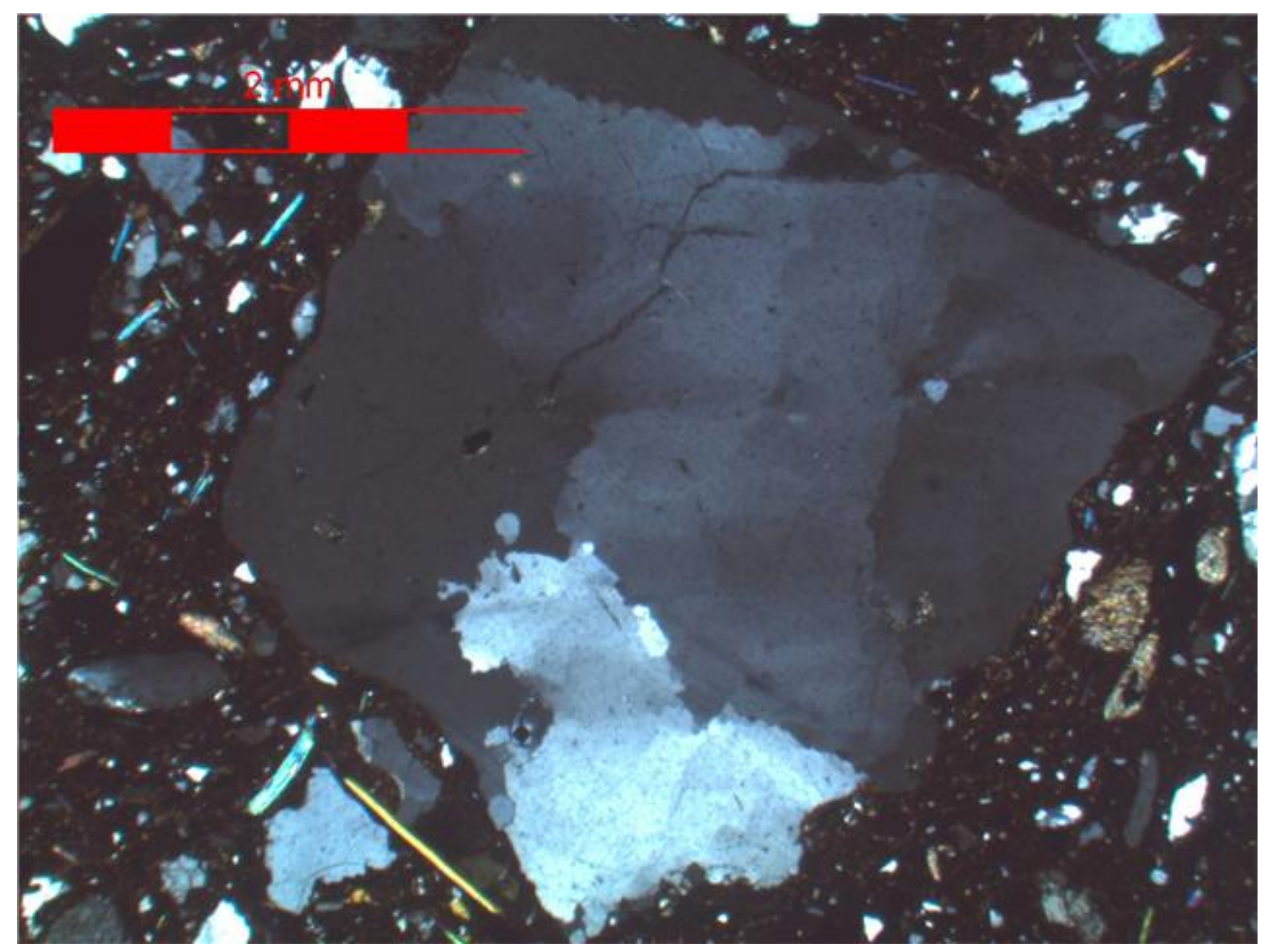

Foto :Szabó,2008.

Quartzo- 6mm envolvido em matriz argilosa

Matriz argilosa 


\section{Perfil 1}

Foto micrografia 9: Lâmina 5: proveniente Perfil 1- Foto :filtros polarizadores cruzados

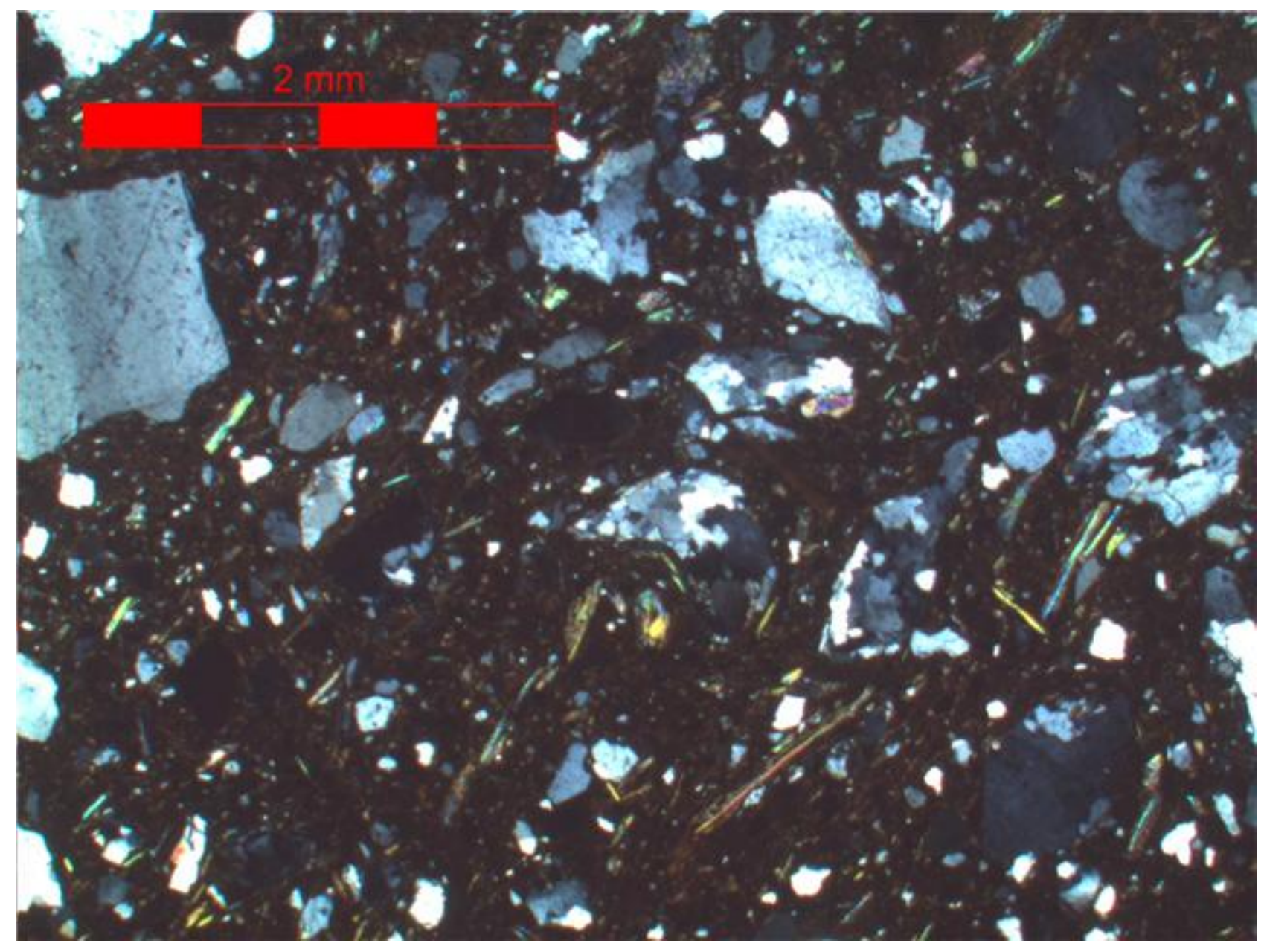

Nesta lâmina é possível observar os diversos tamanhos dos grãos de quartzo presentes na matriz argilosa; as palhetas de mica (tom amarelo) indicam a direção da modelagem da argila. O volume da matriz argilosa oscila conforme o tamanho dos grãos; se os grãos são menores, há um volume maior de matriz argilosa. 
Fotomicrografia 10: Lâmina 5: proveniente Perfil 1- Foto :filtros polarizadores paralelos

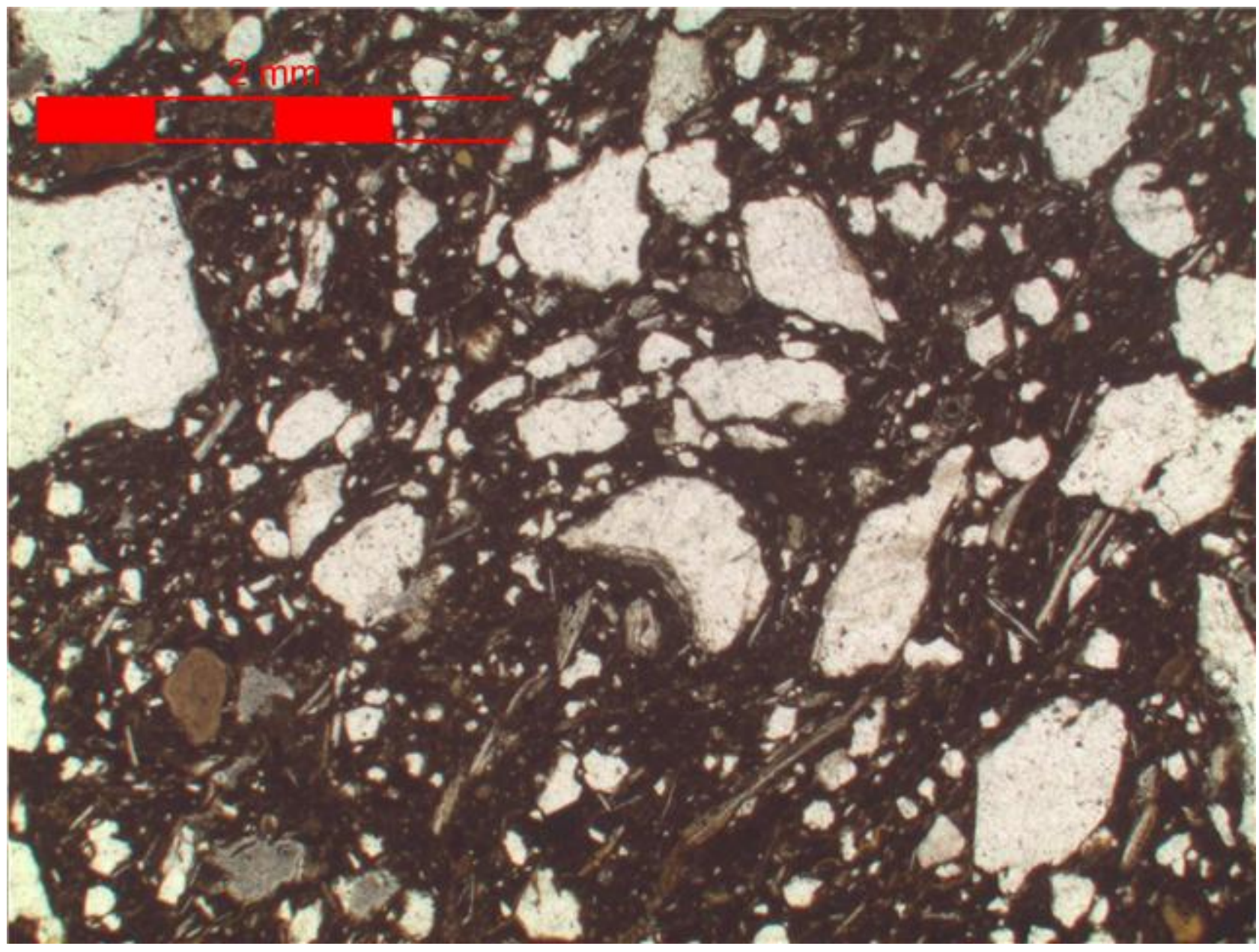

Nesta lâmina é possível observar os diversos tamanhos dos grãos de quartzo presentes na matriz argilosa; as palhetas de mica (tom amarelo) indicam a direção da modelagem da argila. O volume da matriz argilosa oscila conforme o tamanho dos grãos; se os grãos são menores, há um volume maior de matriz argilosa. 
Fotomicrografia 11: Lâmina 5: proveniente Perfil 1- Foto :filtros polarizadores paralelos

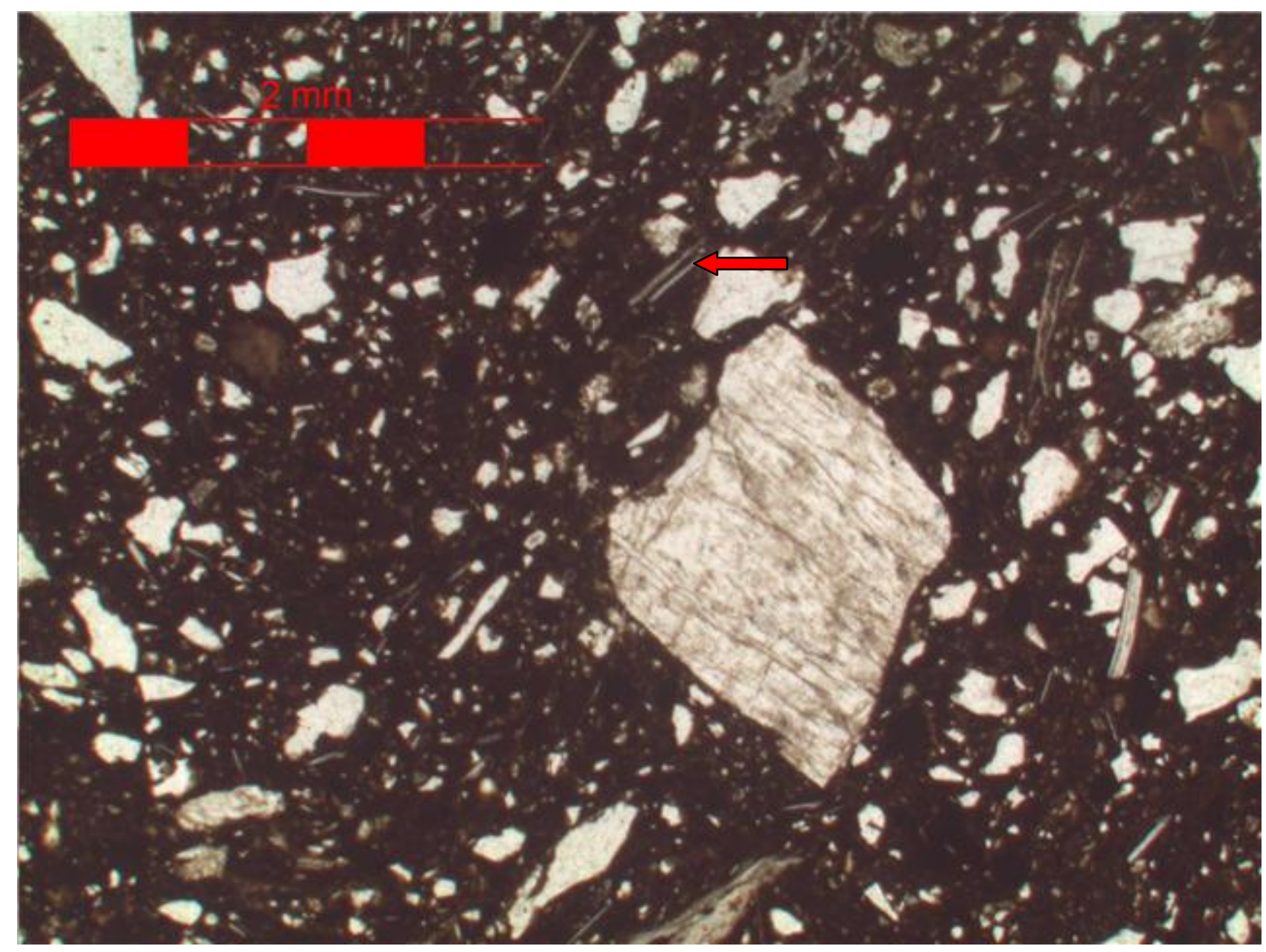

$\hookleftarrow \quad$ Mica

Quartzo 
Fotomicrografia 12: Lâmina 5: proveniente Perfil 1- Foto :filtros polarizadores paralelos
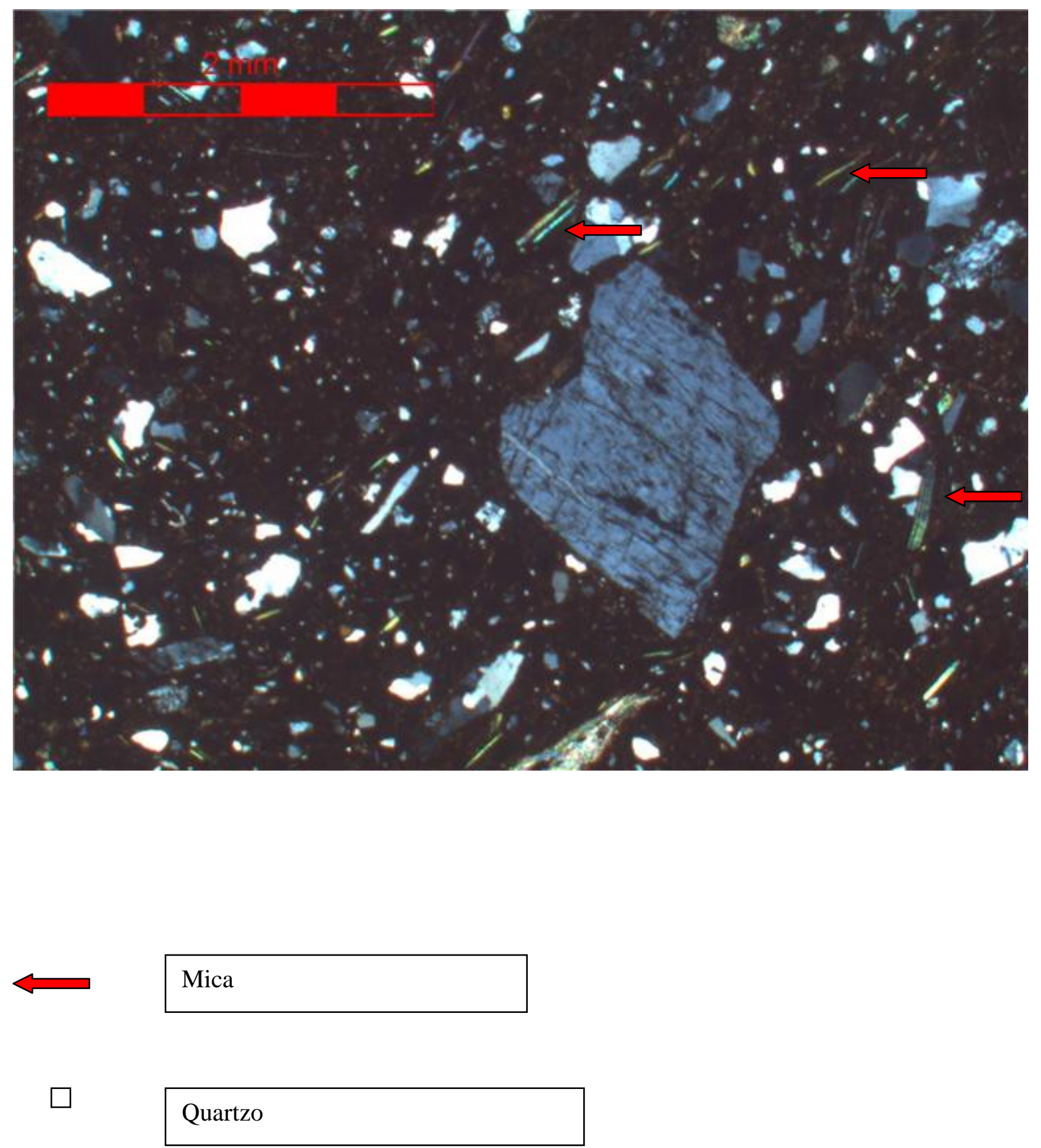


\section{Capítulo 6. Análise Intersítios e considerações finais}

Características específicas do sítio Silva Serrote

A ocupação no sítio Silva Serrote é composto de apenas um estrato lito-cerâmico (uma única ocupação), seguindo o padrão lito-cerâmico colinar (Pallestrinni,1975).

Este sítio apresentou intensidade na produção (703 peças) peças líticas que apontam a caça como uma das atividades sociais praticadas pelo grupo: raspadores, lascas com retoque. Apresenta bolsão de lascamento e intenso número de estilhas. A única peça polida da coleção é um tembetá em sílex, que por analogia etnográfica (Campos,2007) representa a prática de ritos de passagem.

O Uso social dos artefatos/objetos encontrados no sítio Silva Serrote

\begin{tabular}{|l|l|}
\hline Uso Social & Artefatos I objetos \\
\hline Descascar frutos pequenos & Lascas com retoques(pequenas) \\
\hline Raspar o couro e tubérculos & Raspador \\
\hline Rito de passagem(adulto) & Tembetá \\
\hline $\begin{array}{l}\text { Resíduos acidentais e peças preparatórias } \\
\text { para a atividade de lascamento }\end{array}$ & Estilhas/ núcleos \\
\hline
\end{tabular}

Podemos destacar algumas atividades sociais praticadas no sítio Silva Serrote:

O raspador remete à atividade de raspar ou trabalhar o couro e o descascamento de tubérculos.

As lascas pequenas, com retoques sugerem o descascamento de frutos.

O tembetá sugere ornamentação labial que marca algum rito de passagem, gênero ou outro evento de importância social.

A presença dos núcleos e das estilhas são indicadores de atividade de lascamento intra-sítio. 
Segundo Alves (1988 pg. 211), que analisou a indústria cerâmica do sítio Silva Serrote, há o predomínio da cerâmica lisa e a presença de engobo, branco e vermelho, sendo que sobre o engobo branco verificou-se a presença de banho preto. Este engobo seria uma forma de impermeabilizar os recipientes para líquidos.

De forma geral, podemos caracterizar este sítio constituído a partir da ação de populações ceramistas, que confeccionavam artefatos utilitários e funerários(cerimoniais); desenvolveram a indústria cerâmica e conservavam o hábito e de lascar a pedra e do polimento. Praticavam enterramentos de cunho secundário, como evidenciado em urna funerária encontrada no perímetro da aldeia e fora das habitações.

\section{Características específicas do Sítio Menezes}

O sítio Menezes apresentou uma única ocupação, a de horticultores ceramistas; o contexto da aldeia emergiu a partir da evidenciação de quatro espaços habitacionais, uma fogueira, elementos cerâmicos, líticos polidos e lascados. O carvão coletado para a datação encontrava-se na F1. Houve a reconstituição de duas urnas, uma tampa e um almofariz.

Uso social dos artefatos/objetos encontrados no sítio Menezes

\begin{tabular}{|l|l|}
\hline Uso Social & Artefato/objeto \\
\hline Descascar & Lasca com retoque \\
\hline Resíduos de atividade de lascamento & Estilhas/Núcleos \\
\hline Matriz de retirada para atividade de lascamento & Blocos \\
\hline Triturar sementes e grãos & Mão-de-pilão \\
\hline Recipiente para triturar sementes e grãos & Almofariz \\
\hline Desmatamento & Lâmina de machado \\
\hline
\end{tabular}

A indústria lítica do sítio Menezes é composta de artefatos que caracterizam uma economia baseada numa agricultura incipiente.

Dentre os artefatos lascados, podemos destacar os núcleos e os blocos, que são peças de natureza preparatória: a matriz de lascamentos(bloco), e os núcleos a peça esgotada, ou seja, que não apresenta mais superfícies angulosas para o lascamento. As lascas eram utilizadas para descascar frutos.O número de estilhas, peças acidentais ou 
residuais indicam baixa atividade de lascamento ou aperfeiçoamento da técnica. No entanto, estas peças indicam a coexistência da técnica de lascamento com a técnica do polimento/ picoteamento.

Dentre os artefatos polidos, pode-se destacar a lâmina de machado, utilizada para derrubar a mata. A mão-de-pilão tem como função o trituramento de grãos e sementes e o almofariz é o recipiente para esta atividade.

O sítio Menezes apresentou número reduzido de peças líticas, totalizando 24 peças.

Apesar dos afloramentos de quartzo, arenito e sílex no sítio, a produção de artefatos líticos não é intensa. Dentre as peças desta coleção, podemos destacar a lâmina machado polido que está associado ao desmatamento, a mão-de-pilão que indica o trituramento de grãos.

Uso social da cerâmica no sítio Menezes

\begin{tabular}{|l|l|}
\hline $\begin{array}{l}\text { Fiação e tecelagem de fibra vegetal, provavelmente } \\
\text { algodão }\end{array}$ & Fusos perfurados \\
\hline Alimentação, cozimento do milho & Cuscuzeiro \\
\hline $\begin{array}{l}\text { Atividades simbólicas, pode expressar polaridade } \\
\text { entre sol e lua, noite e dia(Silva,2000) }\end{array}$ & Vasos geminados \\
\hline Armazenamento de grãos e sementes & Urnas silo \\
\hline Transporte de grãos-horticultura & Vasilhames cerâmicos de volume médio \\
\hline
\end{tabular}

A produção cerâmica é representativa, totalizando 1939 fragmentos; suas formas e volumes reconstituídos possuem uso associado à estocagem de grãos para a agricultura. $O$ cuzcuzeiro encontrado indica o processamento do milho para consumo. A espessura da parede dos vasilhames em sua maioria fina e média, fato que pode representar que a maioria dos fragmentos sem indicação morfológica constituam o bojo, parte de maior largura dos vasos.

A partir de alguns tipos de vasilhames cerâmicos identificados, podemos inferir algumas atividades sociais praticadas. Os fusos perfurados caracterizam atividades relacionadas à tecelagem de fibra vegetal, provavelmente algodão. A presença dos fragmentos de cuscuzeiro caracterizam o processamento do milho para o cozimento.

A base de vaso geminado indicaria atividade simbólica em relação à representação de polaridades, como por exemplo, sol e lua, noite e dia (Silva, 2000). As urnas silo indicam o 
armazenamento de grãos e sementes; os vasilhames de volume médio podem haver sido utilizados como recipiente para transporte de grãos.

\section{Conclusão}

Acerca das similaridades de ambos os sítios, podemos descrever alguns contextos encontrados e a permanência de algumas técnicas; os sítios do Projeto Quebra-Anzol estudados nessa dissertação são sítios de interior e apresentam o padrão lito-cerâmicio colinar. Ambos os sítios apresentam evidências de combustão a alimentação (manchas escuras ovaladas e fogueiras).

Quanto às atividades sociais correspondentes a indústria cerâmica praticadas por ambos os grupos podemos destacar:

- Uso da técnica acordelada para a modelagem da cerâmica

- O tipo de acabamento ou tratamento utilizado foi o alisamento

(Alguns fragmentos no sítio Silva Serrote que apresentavam alisamento com engobo branco ou vermelho para impermeabilização dos vasilhames -Alves, 1988, pg. 245) e a preferência por argila com grãos maiores ou de baixa seletividade.

- O uso da tecelagem, interpretado pela presença de rodelas de fusos perfurados em ambos os sítios.

- Cosmovisão: presença de vasos geminados ou duplos, que representam atividades simbólicas que pressupunham representações duais.

As atividades pressupostas em relação à indústria lítica:

- Técnicas redutivas: percussão direta unipolar, com uso de percutor duro para a debitagem.

- Os materiais mais utilizados foram quartzo e arenito silicificado; ambos possuem afloramentos na região.

- A presença de estilhas, resíduos de lascamento, núcleos associados às estruturas de habitação e combustão indicam que estes grupos habitavam a região de modo semi-permanente e que confeccionavam seus instrumentos no próprio local de moradia.

- Polimento obtido pela técnica de picoteamento, por meio do uso de areia úmida e couro animal para a abrasão. 
- Presença de bolsões de lascamento.

Em ambos os sítios, houve permanência das técnicas de debitagem do lítico e da confecção da cerâmica, da baixa seletividade de grãos, de tratamento (no sítio Silva Serrote havia presença de engobo (Alves, 1988), a recorrência do tipo de matéria prima utilizada para a indústria lítica, a presença dos vasos geminados e dos fusos de tecelagem indicam que os grupos que habitavam ambos os sítios apresentavam uma conectividade cultural, corroborando desta forma as datações, que convergem em proximidade temporal ${ }^{7}$.

Quanto à proximidade tecnológica com o material da tradição Aratu Sapucaí, a configuração espacial dos sítios e contextos, bem como o processo de confecção da indústria cerâmica do Sítio Menezes demonstram que o material e o sítio podem ser classificados como pertencentes a esta tradição; seguem as generalidades descritas por Martin(1996) e Prous(1992): A tradição Aratu Sapucaí ocupava terrenos de superfícies vastas, promoviam a formação de grandes aldeias, sempre próximas a pequenos córregos e longe dos grandes rios; a indústria cerâmica não possui decoração (às vezes banhos vermelhos); há produção intensa de vasos grandes com cacos espessos, pequenos vasos duplo/geminados e urnas funerárias piriformes.

\footnotetext{
${ }^{7}$ Menezes: escavado no ano de 1991; situado na fazenda São Francisco de Borja, Perdizes-MG. Datado em $572 \pm 80$ anos AP (TL-IF-USP).
}

Silva Serrote: escavado no ano de 1985.Localiza-se na Fazenda Serrote, no município de Guimarânia- MG.

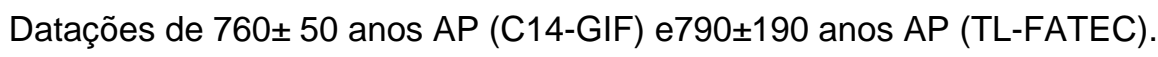




\section{Referências Bibliográficas}

ALVES, M. A.2004. Projeto Quebra-Anzol:complexo arqueológico do vale do Paranaíba,Mingas Gerais. Anais do $3^{\circ}$ Workshop arqueológico de Xingó. Aracajú e Canindé do São Francisco. Setembro de 2004, p 79-83. . 2002. O Sítio Rezende: de acampamento de caçadores-coletores a

Aldeia ceramista pré-histórica. Recife: Clio Arqueológica, v 01, no 15, p 189-203 .1997. Estudo de cerâmica pré-histórica no Brasil: das fontes de matéria-prima ao emprego da microscopia petrográfica, difratometria de raios-X e microscopia eletrônica. Clio, Série Arqueológica, Recife, v.1,nº12,1997.

1996. Metodologia e Técnicas de campo e a evidenciação de áreas culturais. Porto Alegre:

Anais da VIII ${ }^{\mathrm{a}}$ Reunião Científica da Sociedade de Arqueologia Brasileira-Coleção Arqueologia.EDIPUCRS, v.i, p 255-270.

.1994/95. O emprego da microscopia petrográfica,difratometria de raios $\mathbf{X}$ microscopia eletrônica no estudo da cerâmica pré-colonial no Brasil.Revista de Arqueologia , Anais da VII reunião científica da Sociedade de Arqueologia Brasileira., v.08,n02.

.1994. Estudo técnico em cerâmica Pré-histórica no Brasil.Revista do Museu de Arqueologia e Etnologia, MAE/USP.São Paulo, nº4,1994.

.1992/90. Ocupaciones cerâmicas y pré-cerámicas del Estado de Minas Gerais, Brasil. Buenos Aires-Argentina: Paleoetnológica, v 06, p 05-18.

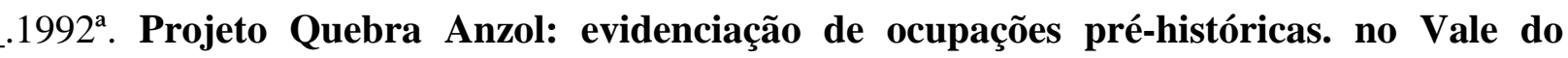
Paranaíba, Minas Gerais. Rio de Janeiro: Anais da VI ${ }^{\mathrm{a}}$ Reunião Cientifica da Sociedade de Arqueologia Brasileira,Univ. Estácio de Sá, v 01, p 118-126.

.1992b. As estruturas arqueológicas do Alto Paranaíba e Triângulo Mineiro- Minas

Gerais. São Paulo: Revista do Museu de Arqueologia e Etnologia /USP, nº2, p 27-47.

.1991. As culturas ceramistas de São Paulo e Minas Gerais: estudo tecnotipológico. Revista do Museu de Arqueologia e Etnologia.MAE/USP,v1, nº 1

.1988. Análise cerâmica: estudos tecnotipológico. Tese de Doutorado

apresentada ao departamento de Antropologia Social da Faculdade de Filosofia, Letras.

.1983/84. Estudo do sítio Prado, um sítio lito-cerâmico colinar. São Paulo: Revista do Museu

Paulista, Nova Série, v: 29, p.169-199 
.1982. Estudo do sítio Prado- um sítio lito-cerâmico colinar. São Paulo: Departamento de História da Faculdade de Filosofia, Letras e Ciências Humanas/ USP. Dissertação de mestrado.

1984/1985.fontes manuscritas:Diário de campo - prospecção e escavação no sítio Silva Serrote.

1990/1991.Diário de Campo prospecção e escavação no sítio Menezes.

1991.Relatório de pesquisa arqueológica e escavação do sítio Menezes.

ALVES,M.A et alli.2002. Horticultores-ceramistas do Vale do Paranaíba, Minas Gerais: padrões de assentamentos, estratigrafia, cultura material e cronologia.Canindé,UFS-Aracajú, $n^{\circ} 2$.

ALVES,M.A \& GIRARDI,A.V.1989. A confecção de lâminas microscópicas e o estudo da pasta cerâmica. Revista de pré-história ,IPH/USP.São Paulo, nº 07

ALVES, M. A. E FAGUNDES,M.2003.Tecnologia da cerâmica pré-histórica do projeto QuebraAnzol.São Paulo,XII Reunião Científica da SAB.(no prelo)

ALVES,M.A E FURLANETO FERREIRA, I.A.1999. Museu municipal de Arqueologia de Monte Alto, SP e o resgate da ancestralidade indígena.X Reunião cientifica da sociedade de arqueologia brasileira. Recife-UFPE.20-24 de setembro, livro de resumos pág.338(painel).

BALFET,H.1983. Pour la normalisation de la description dês potteries.Paris,CNRS.

1991. La ceramique comme document archéologique.Bulletin de la societéprehistorique française.Paris, Tome LXIII, $n^{0} 1$,janvier.

BENI,M.C.2002. Análise estrutural do Turismo.São Paulo,Senac.

BINFORD, L. R.1980.Willow smoke and dog's tails :hunther-gatherer settlement systems and archaeological site formation. American Antiquity,45:4-15.

1995 b. Styles of style. Journal of Anthropology, 8:51-67.

BLEED, P. 2001a. Trees and chains, links or branches: conceptual alternatives for consideration of stone tool production and other sequential activities. Journal of Archaeology Method and Theory, 8 (1).

. 2001 b. Artifice constrained: what determines technological choice? In: M. B.

Schiffer (Ed.). Anthropological perspectives on technology. Albuquerque, University

of New Mexico Press. pp. 151-162.

BROCHADO, J.P.Alimentação na Floresta Tropical.Porto Alegre, Instituto de Filosofia e Ciências Humanas, Universidade Federal do Rio Grande do Sul, 1977. 
CAMPOS, S.M.C.T.L.Bonecas Karajá:modelando inovações, transmitindo tradições.Tese de doutorado,PUC-SP, 2007

CARR,C.1989.Buildings a unified middle-ranged theory of artifact design:historical perspectives and tatics.In: Carr,C. \& Neitzel, J. E.(Eds).Style,society and person(Archaeology and Ethnological perspectives).New York, London,Plenum Press, pp.151-170.

CHYMZ,I.(ed)Terminologia arqueológica brasileira para a cerâmica.Caderno de Arqueologia,

Museu de Arqueologia e artes Populares-Universidade Federal do Paraná.Paranaguá, ano1, $\mathrm{n}^{0} 1,1976$.

DAVID, N. \& KRAMER, C. 2001. Ethnoarchaeology in action. Cambridge, Cambridge University Press. Cap 7.

DIAS, A.S.Repensando a a tradição Umbu através de um estudo de caso.Dissertação de Mestrado.Porto Alegre, Pontifícia Universidade Católica do Rio Grande do Sul.

DIAS \& SILVA. 2001. Sistema tecnológico e estilo: as implicações desta inter-relação no estudo das indústrias líticas do sul do Brasil. Revista do Museu de Arqueologia e Etnologia, São Paulo, 11: 95-108.

DIETLER, M. \& HERBICH, I. 1989. Tich Matek: the technology of Luo pottery

production and the definition of ceramic style. Word Archaeology, 21(1):148-154. . 1998. Habitus, techniques, style: An integrated approach to the social understanding of material culture and boundaries. In: M. Stark (Ed.). The Archaeology of social boundaries. Washington, Smithsoniam Institution P DUNELL, R. C. 1978. Style and Function: A fundamental dichotomy. American Antiquity. 43(2): 192-202.

1986 .Methodological issues in americanist artifact classification.Advances in archaeological method and theory.V.9.:149-207.

FAGUNDES,M.2004. Sítio Rezende:das cadeias operatórias ao estilo tecnológico-um estudo de dinâmica cultural no médio Vale do Paranaíba, Centralina, Minas Gerais. Dissertação de mestrado apresentada ao Departamento de pós-graduação do Museu de Arqueologia e Etnologia da Universidade de São Paulo.

HEGMON, M. 1992. Archaeological research on style. Annual Review Anthropological, 21:517-36. 1998. technology, style and social practices: archeological approaches. In: M. 
Stark (Ed.). The Archaeology of scial boundaries. Washinton, Smithsonian

Institution Press.

IBGE(Instituto Brasileiro de Geografia e Estatística)1958.Enciclopédia de municípios brasileiros. Rio de janeiro,vol.XXIV,p 333-336.

1977.Geografia do Brasil,Região Sudeste. Rio de Janeiro, vol. III.

KAHN, J.S. 1975. El concepto de Cultura: textos fundamentales. Barcelona,

Editorial Anagrama.

KARLIN, C., BODU,J \& PELEGRIN,J.1991.Processus techniques et chaine operatories-comment les préstoriens s'approprient un concept élaboré par les ethnologues.BALFET,H.Observer L’action technique-Dês chaînes opératoires, po quoi fare?Paris,CNRS,pp.101-117.

JONES.S.The archaeology of Ethnicity.London.Routledge.1997.pp 106-127.1997.

JORDAN, P. \& SHENNAN.S.Cultural Transmission.Language and Basketry Traditions amongst the Californian indians.Journal of Anthropological Archaeology.22:42-74-2003.

LA SALVIA,F.;BROCHADO,J.P.Cerâmica Guarani.Porto Alegre:Posenato Arte \& cultura,1989.

LEMONNIER, P. 1992. The study of material culture today: toward na Anthropology of technical systems. Journal of Anthropological Archaeology, 5:147-186.

.1986.Elements for an Anthropology of technology. Michigan, Museum of

Anthropological Research (88), University of Michigan.

LEROI-GOURHAN, A. 1984 a. Evolução e técnicas I - o homem e a matéria. Lisboa, Edições 70. .1984 b. Evolução e técnicas. II - o meio e as técnicas. Edições 70.

Lisboa.

1972. Milieu et techniques(évolution et techniques.Paris:Ed: Albin Michel,1972.

LAMING-EMPERAIRE, A. 1967. Guia para o estudo das indústrias líticas da America

do Sul. Curitiba: Universidade Federal do Paraná - Faculdade de Filosofia, Ciências e

Letras, Departamento de Antropologia, (Manuais de Arqueologia, n.2).

LÉVI-STRAUSS, C. 1974. Introdução à obra de Marcel Mauss. IN: Sociologia e Antropologia. São Paulo, Edusp, pp. 1-36.

MARTIN,G. Pré-história do nordeste do Brasil.Recife.Ed.UFPE,1996.

MAUSS, M.[1934]1991. Tecnicas y movimentos corporales. In: Sociología e 
Antropología. Madrid, Tecnos. pp. 337-353.

1947.Manuel d'ethnografie.Paris.Payot. .1950.Ensaio sobre a dádiva.Edições 70.Lisboa.

1974.As técnicas corporais.In:Sociologia e Antropologia. São Paulo,Edusp,pp.209-331.

MEDEIROS,J.C. 2007.Cultura material cerâmica e lítica das populações dos sítios Inhazinha e

Rodrigues Furtado, município de Perdizes/MG:estudo das cadeias operatórias e dos estilos.

Dissertação de mestrado pelo Departamento de pós-graduação do Museu de Arqueologia e Etnologia da Universidade de São Paulo.

MEGGERS, B. \& EVANS, C. 1970. Como interpretar a linguagem cerâmica: manual

para arqueólogos. Washinton, Smithsonian Institution, 111p.

1985 a. A utilização de referências cerâmicas seriadas para inferir comportamento social.

Séries Ensáio. Instituto Arqueológico Brasileiro, Rio de Janeiro, n.3.

1985 b. Um método cerâmico para o reconhecimento de comunidades pré-

históricas. Boletim. Série Ensáios, I. A.B., Editor: Eliana Carvalho, 3:8-26

MIRAMBELL, L.; LORENZO, J. L. 1983. La cerámica: un documento arqueológico.

México: Instituto Nacional de Antropologia e História.

MORAIS, J. L. 1980. A utilização dos afloramentos litológicos pelo homem pré-histórico brasileiro:

análise do tratamento da matéria-prima. Série Arqueologia, 7. Coleção

Museu Paulista. Fundo de pesquisa do Museu Paulista, USP.

1987. A propósito do estudo das indústrias líticas. Revista do Museu Paulista. v.

XXXII.

MORAIS,J.L .2001.A Arqueologia e o Turismo. IN: FUNARI,P.P \& PINSKY,J. Turismo e patrimônio cultural,São Paulo, Contexto.

O’BRIEN M.J. \& LEONARD R.D. Style and function: an introduction.In:Style and function .Conceptual issues in evolutionary archaeology.T.D.Hurt \&G.F.M. Rakita(eds).Westport.Bergey and Garvey, 2001.

ORTON, C.; TYERS, P.; VINCE, A. 1993. Pottery in archaeology. Cambridge: Cambridge University Press.

PALLESTRINI, L., CHIARA, P. 1976. Indústria lítica de Camargo 76, Município de

Piraju, Estado de São Paulo. In: COLETÂNEA de estudos em homenagem a Annette 
Laming-Emperaire. São Paulo: Museu Paulista.

PALLESTRINI, L. 1975. Interpretação das estruturas arqueológicas em sítios do Estado de São Paulo.

Série Arqueologia. 1, 1. Coleção Museu Paulista, fundo de pesquisa, USP. . 1983. Superfícies Amplas em Arqueologia pré-histórica no Brasil.

Revista de Arqueologia. v. I, n. 1.

REEDY, C. L. \& REEDY, T. J. 1994. Relating visual and technological styles in Tibetan sculpture analysis. Word Archaeology, 25(3): 304-320.

RICE, P. 1987. M. Pottery analysis. Chicago: The University of Chicago Press.

RYE,O. S.Pottery technology.principles on reconstruction.Washington D.C.Australian National University,Manuals on Archaeology,4,1981.

ROE,P.Style,society,myth and structure.1995b.In:Carr,C \&Neitze3l,J.E.(Eds.).Style, Society and person.(Archaeological and Ethnological perpectives)New York

SACKETT, J. 1991.Style and Ethnicity in Archaeology: the case for isochrestis. In:

CONKEY, M. \& HASTORF, C. The uses of style in archaeology. Cambridge,

Cambridge University Press. pp. 32-43.

1977.The meaning of style in archaeology: a general model.American Antiquity, 42(3):369-380.

SCATAMACCHIA,M.C.M. A ocupação Tupi-Guarani no estado de São Paulo:fontes etnohistóricas e arqueológicas.Dédalo.Revista do Museu de Arqueologia e Etnologia da USP.São Paulo, $n^{\circ} 23,1984$.

SCATAMACCHIA,M.C.M.; CAGGIANO,M..A. \& JACOBUS, A.L.O aproveitamento científico de coleções museológicas: proposta para a classificação de vasilhas cerâmicas da tradição tupiguarani.Anais do I Simpósio de Pré-história do nordeste brasileiro.Clio, Recife, Universidade Federal de Pernambuco,nº 4,1991.

SCHIFFER.M.B. \& SKIBO.J.The explanation of artifact variability. American Antiquity.62(1)2750.

SERONIE-VIVIEN,M.R.Introdution à l'étude des potteries prehistoriques.Paris, Le Bouscat, 1975. SHEPARD, A.1963. Ceramics for the archaeologist. Washinton: Carnegie Institution.

SOUZA, A.M. Dicionário de Arqueologia. Rio de Janeiro, Associação de Docentes da Estácio de Sá,1997.

TEJERO,N.C. \& LITVAK,J.Un sistema de estudio para formas de vasijas.Instituto Nacional de Antropologia e História.México,1968. 
TIXIER, J. 1980. Préhistoire de la pierre taillée, 1: terminologie et technologie. Antibes,

France: C.R.E.P.

VILHENA-VIALOU, A. 1980 Tecno-tipologia das indústrias líticas do sítio Almeida em seu quadro natural, arqueo-etnolígico e regional, Museu Paulista/Instituto de Pré-

História. USP.

WASHBURN.D.K.The property of Symmetry and the concept of ethnic Style.In:S.J.

Shennan.Archaeological Approaches to cultural identity.London,Routledge.pp 157-173.

WHITAKER,J.C.;CAULKINS D. \& KAMP,.K.A; Evaluating Consistency in Tipology and

classification.Journal of Archaeological Method and Theory.V.5 N.2:129-164,1998.

WIESSNER, P.1983. Style and social information in Kalahari San Projectile Points.

American Antiquity. 48(2): 253-276.

. 1991. Is there a unity to style? In: CONKEY, M. \& HATORF, C. The uses

of style in Archeology. Cambridge, Cambridge Universty Press. pp. 105-112.

\section{Fontes mapas}

Mapa vegetação Minas Gerais: www.geominas.mg.gov.br/.../mapas/vegetnat.html

Mapa cidade de Perdizes e Guimarânia www.google.com.br

Mapa hidrográfico:www.ambientebrasil.com.br

Mapa geológico: $\underline{w w w . w e b c a r t a . n e t}$

\subsection{Referências consultadas}

ALVES,M.A.1985. Diário de campo: escavação do sítio. Silva Serrote.Guimarânia-MG, manuscrito.

.1991. Diário de campo: escavação do sítio Menezes. Perdizes-MG,manuscrito.

CREMONTE,M.B.Alcances y objetivos de los estúdios tecnológicos em la cerámica arqueológica.Anales de Arqueologia e Etnologia .Universidade Nacional de Cuyo, faculdades de Filosofia y Letras.Argentina,v.38/40,1983/85. 
CREMONTE,M.B.Análisis de muestras cerámicas de la quebrada de Humahuaca.Avances en Arqueologia.Tilcara-Jujuy. Faculdade de Filosofia y letras, UBA,Instituto interdisciplinário Tilcara.Argentina,1990/91.

CUCHE,D.A noção de cultura nas ciências sociais.Bauru.Editora da Universidade do Sagrado Coração.1999.

FOGAÇA,E.2001.Mãos para o pensamento..Porto Alegre, Pontífice Universidade Católica(PUCRS),tese de doutoramento.

GOULART,E.P.2004.Técnicas instrumentais para a caracterização minerológica e microestrtural de materiais cerâmicos arqueológicos.Aracajú,Canindé-Revista do MAX, n04, pp, 249;271.

HODDER, I.1988. Interpretación em Arqueologia.Barcelona: Crítica.

OAKLEY,K.P.Man the tool maker. Inglaterra, British Museum,1972.

TEJERO,N.C. \& LITVAK,J.Un sistema de estudio para formas de vasijas.Instituto Nacional de Antropologia e História.México,1968. 